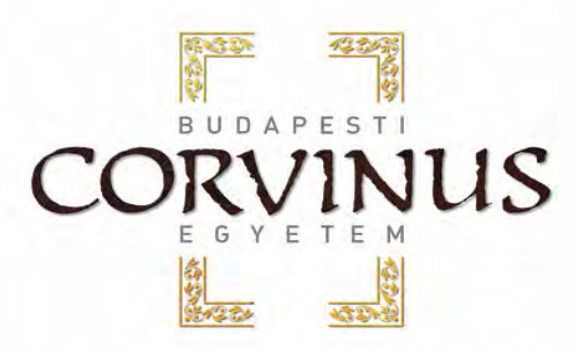

Doktori (PhD) értekezés

\title{
HAZAI EREDETÜ ERWINIA AMYLOVORA BAKTERIOFÁGOK JELLEMZÉSE ÉS FELHASZNÁLÁSÁNAK LEHETŐSÉGE A BIOLÓGIAI VÉDEKEZÉSBEN
}

\author{
Kolozsváriné Nagy Judit
}

Magyar Tudományos Akadémia, Agrártudományi Kutatóközpont, Növényvédelmi Kutatóintézet

\section{Budapest}


A doktori iskola

megnevezése:

tudományága:

vezetője:

témavezető:

társtémavezető:
Kertészettudományi Doktori Iskola

Növénytermesztési és Kertészeti Tudományok

Dr. Tóth Magdolna egyetemi tanár, DSc

Budapesti Corvinus Egyetem, Kertészettudományi Kar, Gyümölcstermő Növények Tanszék

Dr. Schwarczinger Ildikó, PhD

tudományos fömunkatárs

Magyar Tudományos Akadémia, Agrártudományi Központ, Növényvédelmi Kutatóintézet, Biotechnológia Osztály

Dr. Tóth Magdolna egyetemi tanár, DSc

Budapesti Corvinus Egyetem, Kertészettudományi Kar, Gyümölcstermő Növények Tanszék

A jelölt a Budapesti Corvinus Egyetem Doktori Szabályzatában elöírt valamennyi feltételnek eleget tett, az értekezés mühelyvitájában elhangzott észrevételeket és javaslatokat az értekezés átdolgozásakor figyelembe vette, ezért az értekezés, védési eljárásra bocsátható.

Dr. Tóth Magdolna

az iskolavezető jóváhagyása
Dr. Schwarczinger Ildikó

a témavezető jóváhagyása
Dr. Tóth Magdolna

a társtémavezető jóváhagyása 
A Budapesti Corvinus Egyetem Élettudományi Területi Doktori Tanácsának 2014. október 7-i határozatában a nyilvános vita lefolytatására az alábbi bíráló Bizottságot jelölte ki:

\section{BÍRÁLÓ BIZOTTSÁG}

\section{Elnöke}

Palkovics László, DsC

\section{Tagjai}

Barna Balázs, DsC

Damjanova Ivelina, $\mathrm{PhD}$

Olasz Ferenc, $\mathrm{PhD}$

Mergenthaler Emese, PhD

Opponensek

Szegedi Ernő, DSc

Karacs-Végh Anita, PhD

\section{Titkár}

Mergenthaler Emese, PhD 


\section{Tartalomjegyzék}

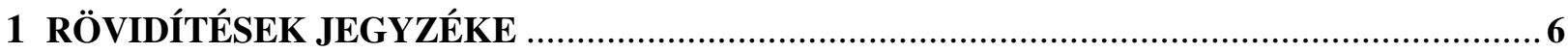

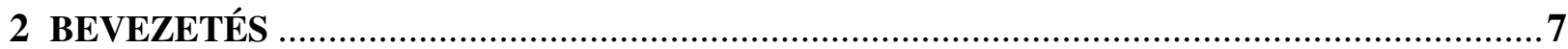

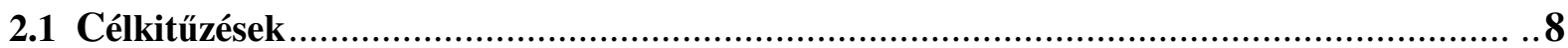

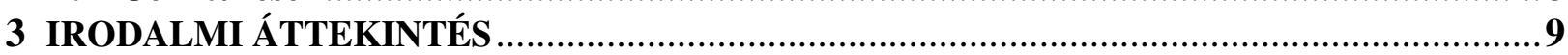

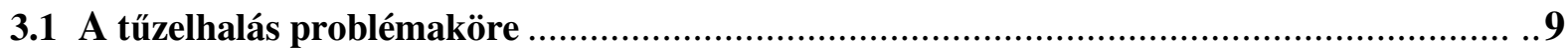

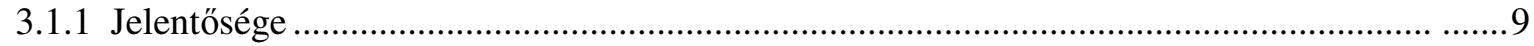

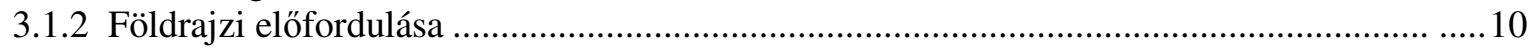

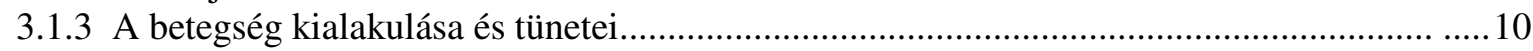

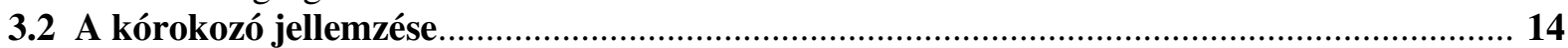

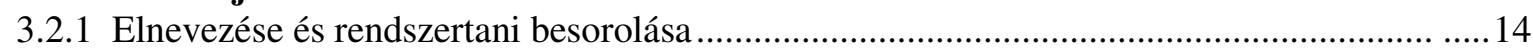

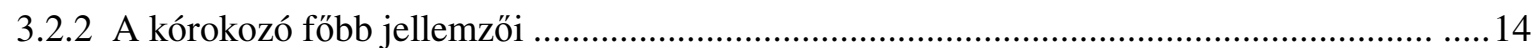

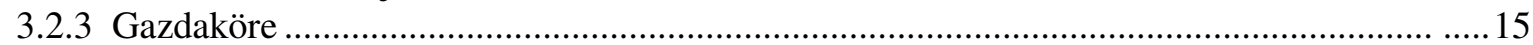

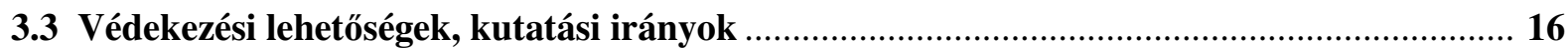

3.3.1 Növény-egészségügyi szabályok, agrotechnikai módszerek .................................................. 16

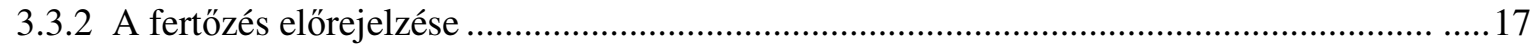

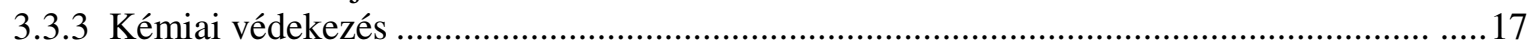

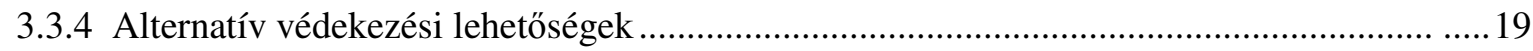

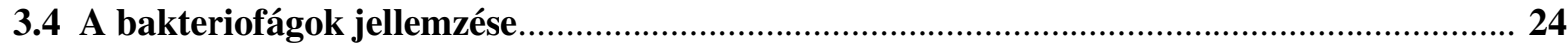

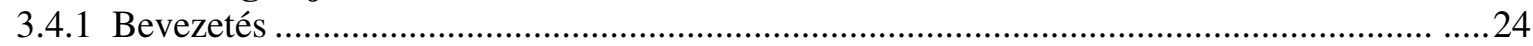

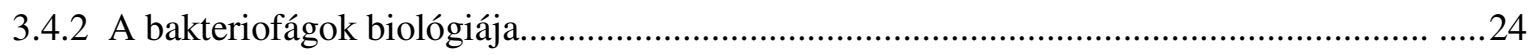

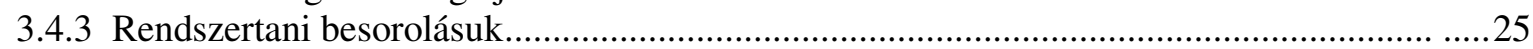

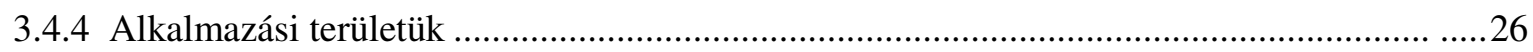

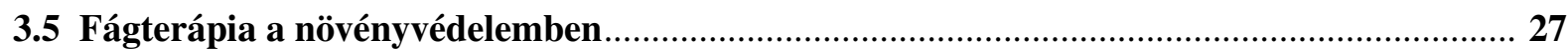

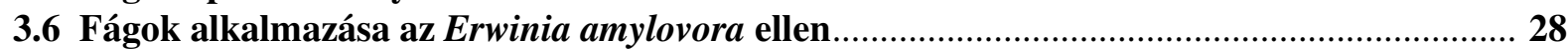

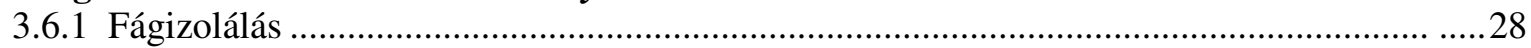

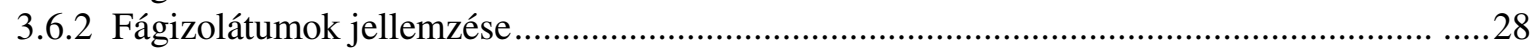

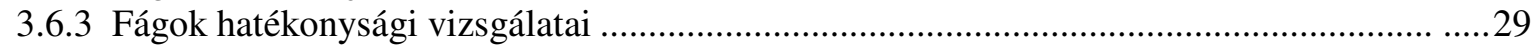

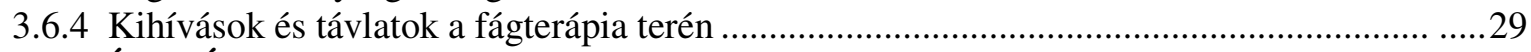

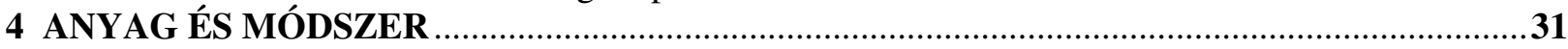

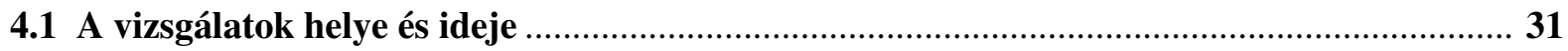

4.2 A vizsgálatok során használt baktérium-izolátumok, illetve törzsek ……............................ 31

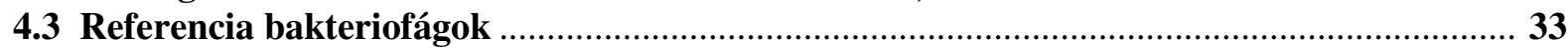

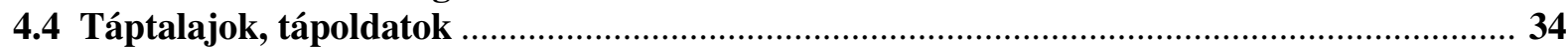

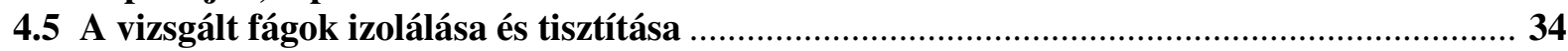

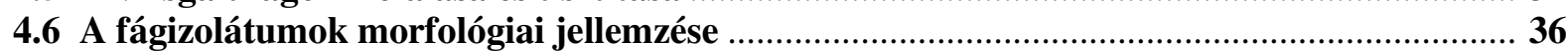

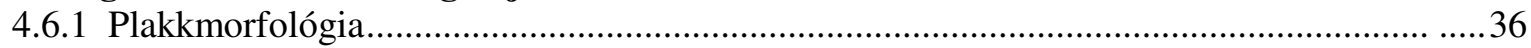

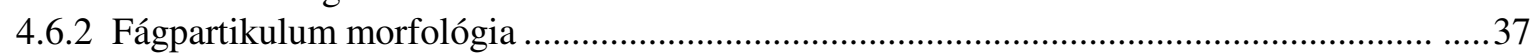

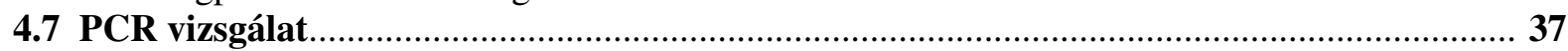

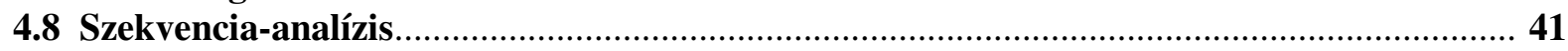

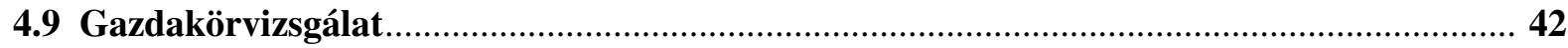

4.10 Fágok és fágkombinációk Erwinia amylovora baktériumra gyakorolt hatásának

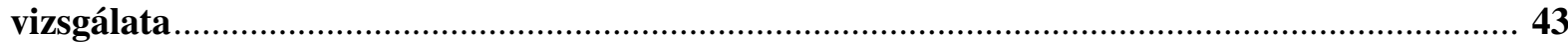

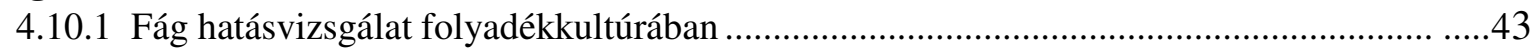

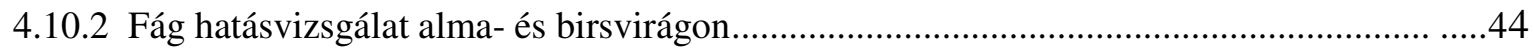

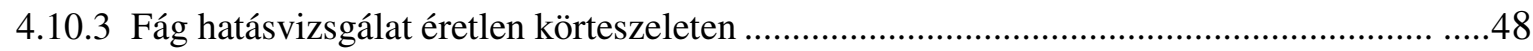

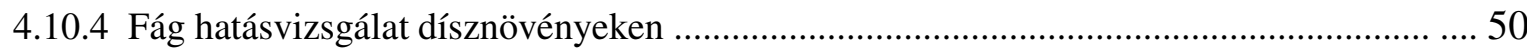

4.11 A fágkezelés hatékonyságának fokozására irányuló vizsgálatok: fágok növénybe jutása, transzlokációja és az E. amylovora okozta tünetekre gyakorolt hatása ..................................... 51

4.11.1 A fágok transzlokációs képességének alma csíranövényekben történő vizsgálata -

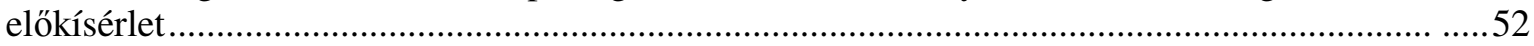

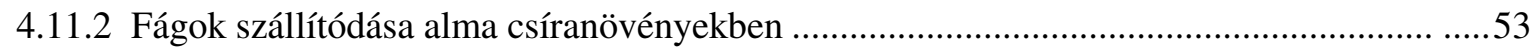

4.11.3 A fágok hatása az E. amylovora okozta tünetekre ..........................................................54

4.11.3.1 Alma csíranövények gyökérzónájához, illetve föld feletti részeire juttatva ki a fágokat 
4.11.3.2 A fágokat alma csíranövények sziklevelébe injektálva ........................................56

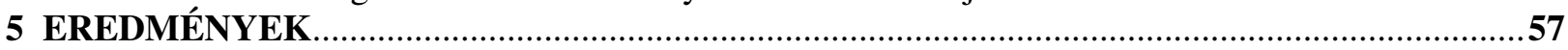

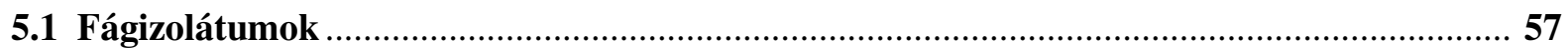

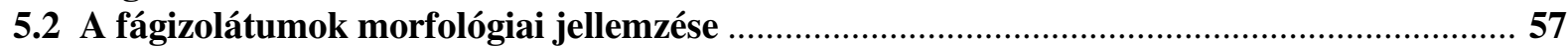

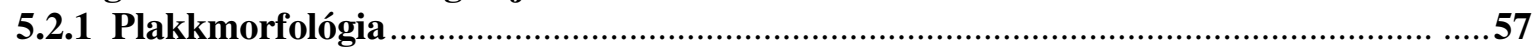

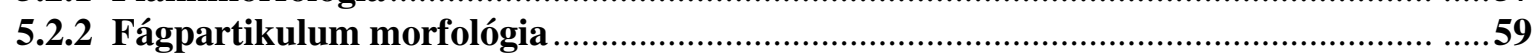

$5.3 \mathrm{Az}$ izolált fágok molekuláris jellemzése

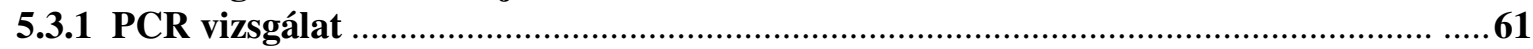

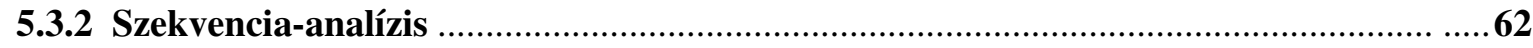

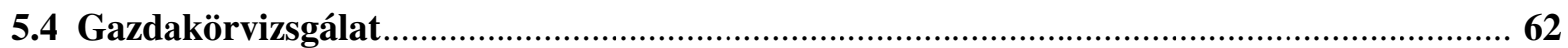

5.5 Fágok és fágkombinációk hatásának vizsgálata az Erwinia amylovora baktériumra ........... 66

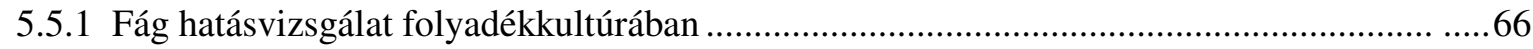

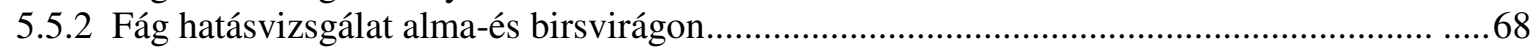

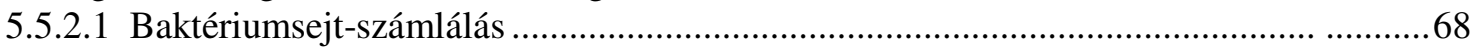

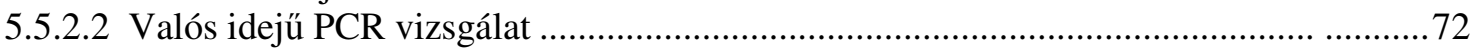

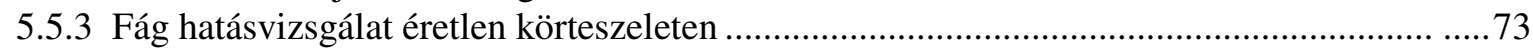

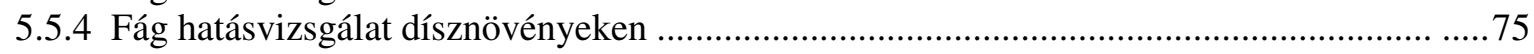

5.6 A fágkezelés hatékonyságának fokozására irányuló vizsgálatok: fágok növénybe jutása, transzlokációja és az E. amylovora okozta tünetekre gyakorolt hatása ……............................... 76

5.6.1 A fágok transzlokációs képességének alma csíranövényekben történő vizsgálata

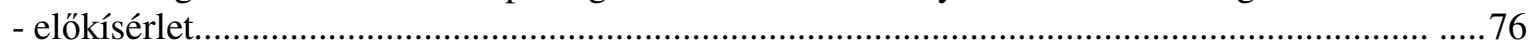

5.6.2 Fágok szállítódása alma csíranövényekben …………………………………....................... 77

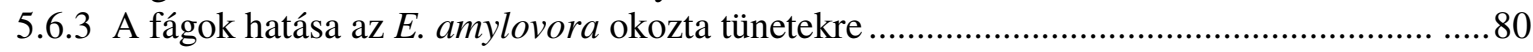

5.6.3.1 Alma csíranövények gyökérzónájához, illetve a növény föld feletti részeire juttatva

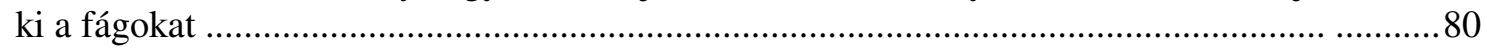

5.6.3.2 A fágokat alma csíranövények sziklevelébe injektálva .......................................... 81

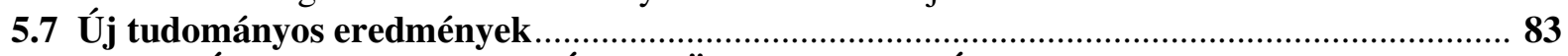

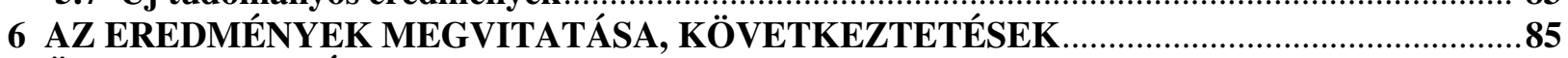

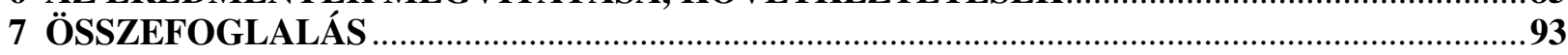

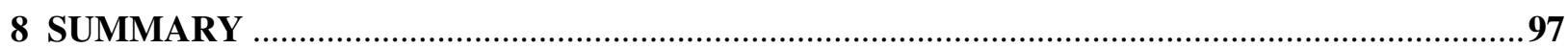

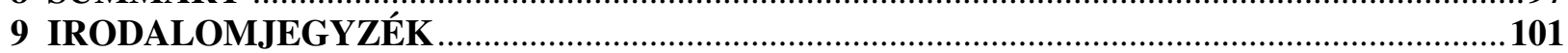

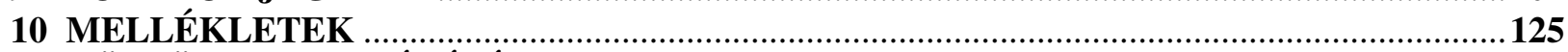

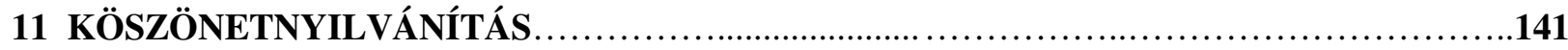




\section{RÖVIDÍTÉSEK JEGYZÉKE}

\begin{tabular}{|c|c|}
\hline ANOVA & Analysis of Variance (varianciaanalízis) \\
\hline bp & bázispár \\
\hline $\mathrm{CFU}$ & Colony Forming Unit (baktériumkolóniát képző egység) \\
\hline CPG & Casamino-acid Peptone Glucose táptalaj \\
\hline EPS & Extracelluláris poliszacharid \\
\hline $\mathrm{kb}$ & kilobázis (ezer nukleotid) \\
\hline KB & King's B táptalaj \\
\hline LB & Luria-Bertani tápoldat \\
\hline LBA & Agart tartalmazó szilárd LB táptalaj \\
\hline marker & $\begin{array}{l}\text { PCR vizsgálatoknál a DNS-szakaszok méret meghatározására szolgáló } \\
\text { standard „létra” }\end{array}$ \\
\hline NA & Nutrient Agar \\
\hline NB & Nutrient Broth \\
\hline $\mathrm{OD}_{600}$ & $\begin{array}{l}\text { Optical Density (optikai sűrüség) } 600 \text { nanométer } \\
\text { fényhullámhosszon }\end{array}$ \\
\hline PCR & Polymerase Chain Reaction (polimeráz-láncreakció) \\
\hline PFU & Plaque Forming Unit (plakkot képző egység) \\
\hline ppm & $\begin{array}{l}\text { parts per million ( } \mathrm{mg} \mathrm{l}^{-1} \text { koncentrációnak megfelelö } \\
\text { mértékegység) }\end{array}$ \\
\hline $\mathrm{rpm}$ & revolutions per minute (egy percre eső fordulatok száma) \\
\hline SSR & Short-Sequence Repeat (rövid-szekvencia-ismétlődés) \\
\hline TEM & $\begin{array}{l}\text { Transmission Electron Microscopy (transzmissziós } \\
\text { elektronmikroszkópos vizsgálati módszer) }\end{array}$ \\
\hline Tukey-féle HSD próba & Tukey's Honestly Significant Difference (statisztikai teszt) \\
\hline
\end{tabular}




\section{BEVEZETÉS}

Az almatermésűek tűzelhalása az Erwinia amylovora (Burrill) Winslow et al. baktérium által elöidézett, a Rosaceae családba tartozó számos növényfaj legsúlyosabb baktériumos betegsége (Bonn és van der Zwet 2000). A betegség elsődleges tünetei kora tavasszal, a virágokon jelentkeznek, amelyek vizenyősek lesznek, majd elfeketednek a kórokozó nektáriumokon keresztül elindított fertőzésének következtében. Miután a baktérium természetes nyílásokon és sebzéseken keresztül bejutott a növénybe, a hajtások, levelek hervadnak, az ágak nekrotizálódnak, majd végül elpusztulnak (Vanneste és Eden-Green 2000). Az Amerikai Egyesült Államokban honos kórokozót az 1950-es évek közepén hurcolták be Európába (OEPP/EPPO 1983). Magyarországon először 1995-ben azonosították egy Kecskemét termesztési körzetében levő alma ültetvényben (Hevesi 1996).

A betegség elleni hatékony védekezés - melynek alapeleme a fertőzési források időben való lokalizálása érdekében végzett folyamatos megfigyelés - a rendelkezésre álló kémiai és egyéb szerekkel nem megoldott, mióta az eddigi legeredményesebb védekezési mód, a virágzáskori sztreptomicines kezelés a legtöbb európai országhoz hasonlóan Magyarországon sem engedélyezett. Sztreptomicin-rezisztens E. amylovora törzsek megjelenése (Miller és Schroth 1972), valamint az egyre általánosabbá vált nézet, mely szerint csökkentenünk kell a környezeti peszticidterhelést, és kerülni kell a különösen humán toxikológiai szempontok alapján kockázatos antibiotikumok növényvédelmi célú használatát különböző, köztük számos biológiai védekezési mód kutatásához vezetett. Ezek egyike a bakteriofágok használatára épül.

A bakteriofágok, azaz a baktériumok vírusai, korábban már számos vizsgálatban bizonyultak hatékonynak különböző bakteriális eredetü növényi betegségek, köztük az almatermésüek tüzelhalása ellen is (Jones és mtsai. 2007). PhD hallgatóként 2011-ben kapcsolódtam be a hazánkban Dr. Schwarczinger Ildikó által 2006-ban megkezdett kutatásba, melynek célja a hazai E. amylovora bakteriofágok izolálását, jellemzését és azok E. amylovorara kifejtett hatásának a vizsgálatát magába foglaló E. amylovora elleni bakteriofág-alapú biológiai védekezés megalapozása. Az E. amylovora baktérium hazánkban karantén kórokozó, ezért szabadföldi kísérletek végzése e kórokozóval nem engedélyezett. Az in vitro kísérletek a Magyar Tudományos Akadémia, Agrártudományi Kutatóközpont, Növényvédelmi Intézet (MTA ATK NÖVI) Biotechnológiai osztályának akkreditált Erwinia-laboratóriumában történtek a 75280 számú PD OTKA pályázat támogatásával. 


\subsection{CÉLKITÜZÉSEK}

- E. amylovora-specifikus bakteriofágok magyarországi gyüjtése és izolálása a tüzelhalás elleni biológiai védekezésben való felhasználásuk vizsgálata céljából

- Az izolált hazai fágok jellemzése és az Amerikai Egyesült Államokban gyüjtött néhány E. amylovora-specifikus fágtörzzsel történő összehasonlítása

- A leghatékonyabb fágizolátumok kiválasztása, a fágok E. amylovora baktérium szaporodására gyakorolt hatásának in vitro vizsgálata különböző tesztnövényeken és növényi mintákon

- Az E. amylovora fágok növénybe jutásának, és növényen belüli szállítódásának tisztázása, valamint a tüzelhalás tüneteire gyakorolt hatásának vizsgálata 


\section{IRODALMI ÁTTEKINTÉS}

\subsection{A TÜZELHALÁS PROBLÉMAKÖRE}

\subsubsection{JELENTŐSÉGE}

Az almatermésüek tüzelhalása, vagy korábbi elnevezések szerint az alma és a körte hajtásszáradása (Klement 1965), a körte (és az alma) erviniás elhalása (Glits 1993), az almatermésűek baktériumos hajtásszáradása és elhalása (tűzelhalás) (Németh 1997), baktériumos ágelhalás (G. Tóth 1997) egy olyan egyedülálló, térben és időben szórványosan előforduló növényi betegség, amelyről elsőként mutatták ki, hogy egy baktérium okozza (Baker 1971).

Ez az almatermésü növények egy részének régtöl ismert, egyik legjelentősebb bakteriális eredetű betegsége nagymértékü gazdasági károkat képes elöidézni alma-, körte- és birsültetvényekben (van der Zwet és Keil 1979) mind a mai napig. Tényleges gazdasági hatását nehéz megállapítani, mivel egyrészt a csekély veszteséggel, azaz egy tenyészidőszakon belül csupán kevés fertőzött virágbogból kiinduló és néhány fa kivágásával járó fertőzésekről sokszor nem számolnak be, másrészt már egyetlen, a kórokozó számára optimális környezeti feltételek beálltakor kitörő járvány akár évekre tönkreteheti az adott alma-, illetve körteültetvényen folyó gyümölcstermesztést. Csupán érzékeltetésként: Bonn (1999) közlése alapján a tüzelhalás által 1998-ban okozott veszteség mértékét az USA észak-nyugati részén több mint 68 millió amerikai dollárra becsülték.

Ami a magyarországi fertőzések által okozott károk mértékét illeti elmondható, hogy 1996ban, a betegség hazai megjelenésének évében, 1,1 millió amerikai dollárra volt tehető a több tízezer fertőzött alma-, birs- és körtefa, valamint több száz dísznövény megsemmisítésének összköltsége (Bonn és van der Zwet 2000). A fellépő erős fertőzöttség következtében jelentős mértékű fertőzött növényállomány felszámolására volt szükség 2000-ben (Pálfi és mtsai. 2000), valamint 2004-ben Szabolcs-Szatmár-Bereg (Mérő 2004) és Borsod-Abaúj-Zemplén megyékben (Csete és mtsai. 2004) is. Az elmúlt két évben pedig Szabolcs-Szatmár-Bereg és a Hajdú-Bihar megye Nyírségig húzódó részén teremtettek az időjárási viszonyok optimális körülményeket az E. amylovora fertőzésére és ennek következtében ezekben a térségekben ismét járványos méreteket öltött a betegség (Fülep 2014). 


\subsubsection{FÖLDRAJZI ELŐFORDULÁSA}

Az almatermésủek tủzelhalásának részletes földrajzi elterjedéséről alapos szakirodalom áll rendelkezésünkre (Bonn és van der Zwet 2000, Végh 2012). A betegséget az Amerikai Egyesült Államok területén, a New York állambeli Hudson-völgyben észlelték először 1780-ban (Denning 1794), ahonnan fertőzött szaporító- és ültetési-anyaggal déli és nyugati irányba terjedve, az 1800-as évek elején már a gyümölcstermesztés egyik jelentős növényvédelmi problémájának tartották Észak-Amerikában (Coxe 1817). Az észak-amerikai kontinensen kívül elsőként Japánból (Uyeda 1903), majd Új-Zélandról (Campbell 1920) számoltak be a betegségröl. Európában 1956-1957-ben figyeltek fel először a tüzelhalás tüneteire Angliában (Kent) (Lelliott 1959) és nem sokkal ezt követően észlelték a betegséget Egyiptomban, a Nílus deltavidékén (El-Helaly és mtsai. 1964) is. E két helyről mára majdnem valamennyi európai és közel-keleti ország területére eljutott és szét is terjedt a kórokozó. A tüzelhalás magyarországi első megjelenésének közlése Dr. Hevesi Mária nevéhez füződik (Hevesi 1996) aki, miután a délalföldi Nyárlőrincen lévő egyik almaültetvényben 1995 késő őszén és 1996 kora tavaszán észlelte a betegség tüneteit, azonosította a kórokozót. Azóta az egész országban elterjedt (Bubán és mtsai. 2007, Németh 1997, Végh 2012) és az időjárási viszonyok függvényében időről időre számítani lehet járványszerü fellépésére. 2004-ben már 46 országban fordult elő (van der Zwet 2006). A legutolsó európai ország, ahol újonnan észlelték a kórokozót Szlovénia volt, 2001-ben (Dreo és mtsai. 2006).

\subsubsection{A BETEGSÉG KIALAKULÁSA ÉS TÜNETEI}

A tüzelhalás epidemiológiájáról alapos áttekintést nyújt Thomson (2000) összefoglaló munkája. A kórokozó életciklusára jellemzően az előző évben fás részeken kialakult rákos sebekben áttelt baktériumok indítják el tavasszal a virágokon az új fertőzéseket. Ennek az elsődleges virágfertőzésnek a kritériumai Steiner (1990) alapján a következők: (1) legyenek kinyílt, ép virágok; (2) a $18,3^{\circ} \mathrm{C}$ feletti óránkénti hőmérsékleti átlagokból adódó úgynevezett kritikus höösszeg érje el a 110-es értéket, illetve az újabb kutatások eredményeinek fényében Fülep (2014) szerint már a $70^{\circ} \mathrm{C}$ kritikus hőösszeg is elegendő; (3) legyen jelen minimum 0,25 mm mennyiségü csapadék (eső vagy pára), vagy az előző napon hulljon legalább 2,5mm eső; (4) a napi átlaghőmérséklet érje el a $15,6^{\circ} \mathrm{C}$-ot, illetve Fülep (2014) utal arra, hogy a $15,3^{\circ} \mathrm{C}$ is elégséges. A fertőzött fák rákos (üszkös) sebeinek általában a szélén meghúzódó baktériumok gyakorta egy nedvszívó poliszacharid anyagban helyezkednek el, és az így képzett ragadós nyálka vagy folyékony marad, vagy kiszáradva borostyán-sárga, fénylő mázzá keményedik. Ezzel kapcsolatban érdemes kiemelni azt, hogy a fertőzésnek nem feltétele ennek a nyálkának a 
sebekből történő kiválása, mivel a baktériumsejtek még a beszáradt nyálkacseppekben is életképesek tudnak maradni egy évig (Rosen 1938). Az áttelelt baktériumok tavasszal a baktériumnyálkát látogató rovarok (hangyák és legyek) révén, vagy eső és szél útján kerülnek a bibék felszínére, ahol szaporodni kezdenek. Az elszaporodott epifiton populáció egy része helyben indítja el a fertőzést, illetve viráglátogató rovarok, eső, vagy metszés által távolabbi virágokra terjed át és a virág természetes nyílásain, elsősorban a nektáriumok (Bubán és mtsai. 2003a, 2003b), valamint a bibe, a portokok és a csészelevelek természetes résein keresztuil (Hildebrand 1937) a virág szöveteibe hatol és annak sejt-közötti járataiban szaporodni kezd. Az egyes virágok vagy virágbogok először nedvesen átitatottakká válnak, fonnyadnak, majd megbarnulnak, megfeketednek, elhalnak és rendszerint a fán maradnak (1-2. ábra).

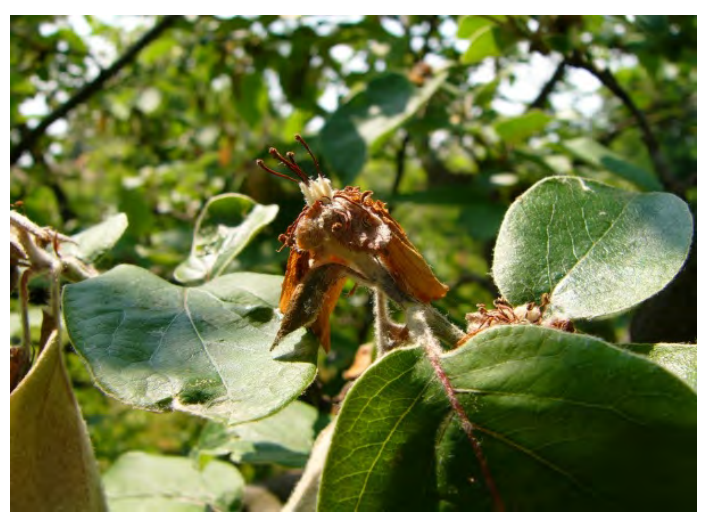

1. ábra E. amylovora-val fertőzött birs (Cydonia oblonga Mill.) virág (Fotó: Kolozsváriné N.J.. 2004. Siófok)

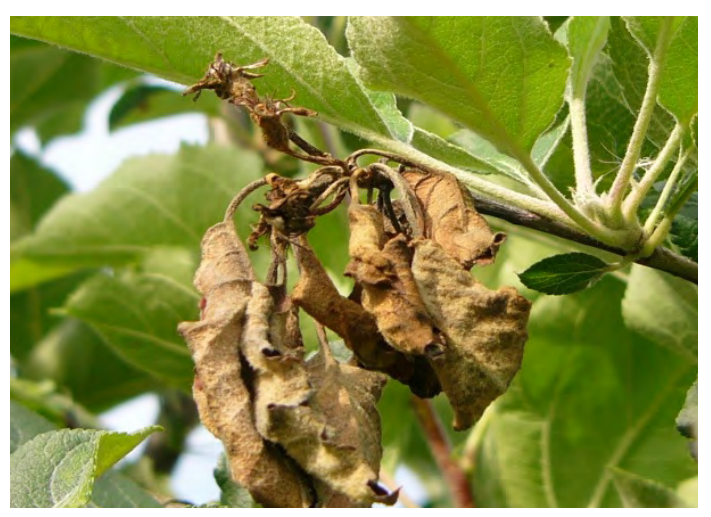

2. ábra E. amylovora-val fertőzött alma (Malus x domestica Borkh. 'Golden') virágok (Fotó: Kolozsváriné N.J., 2007, Siófok)

A kórokozó endofiton populációi a fogékony gazdanövényben, kedvező időjárási feltételek mellett gyorsan haladnak a virágból a kocsányon át a hajtásokba, vesszőkbe, majd az ágakba, akár le egészen a törzsig (Vanneste és Eden-Green 2000), ahol üszkös sebek alakulnak ki. Néha azonban a xilemben ,ragadnak” és mindaddig nem okoznak tüneteket, amíg a háncs parenchima szöveteibe ki nem jutnak (Vanneste és Eden-Green 2000). Meleg, párás időszakokban a gyökér kivételével bármely fertőzött növényi részen (virág, levél, hajtás, gyümölcs, ág, törzs, és gyökérnyak) megjelenhetnek baktériumsejteket tartalmazó nyálkacseppek, melyek az eső, rovarok, madarak, és az ember közvetítésével további fertőzéseket indukálnak. A közvetlen virágfertőzés által szisztemikusan fertőződött éretlen gyümölcsök szürkésen vizenyőssé válnak, barnulnak, megfeketednek, lehullanak, vagy mumifikálódva a vesszőkön maradnak (3. ábra). 


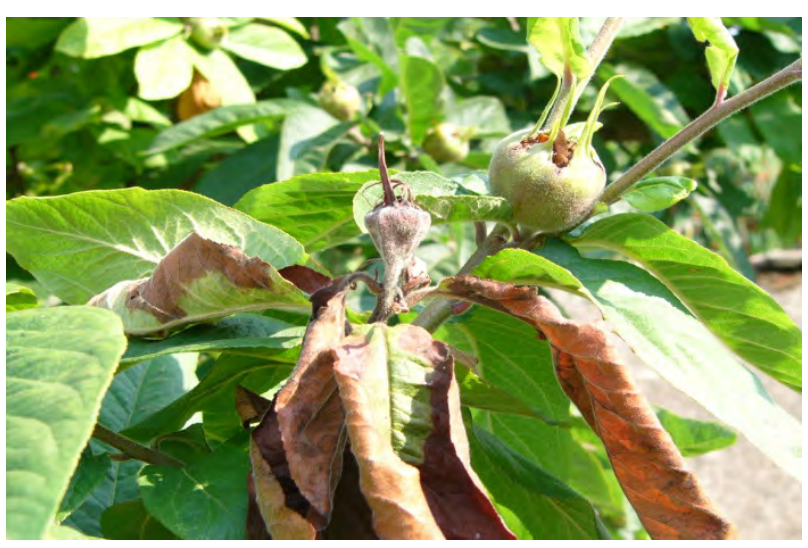

3. ábra A tủzelhalás tünetei naspolya (Mespilus germanica L.) éretlen gyümölcsein (Fotó: Kolozsváriné N.J., 2007, Siófok)

Az elsődleges fertőzés kezdetén felszaporodott baktériumsejtek azonban nem csak virágokra szállítódnak el, hanem a nyár folyamán kifejlődő fiatal hajtásokhoz, tősarjakhoz, vízhajtásokhoz is eljutnak, ahol a sztómákon, hidatódákon, lenticellákon, vagy jégeső, szélverés, metszés okozta sebzéseken keresztül a levelekbe és a hajtások szárába hatolnak és így idézik elő a hajtásfertőzést. Az ilyen fiatal hajtások E. amylovora baktériummal való fertőzöttségének jellegzetes tünete az elbarnuló, elfeketedő hajtásvégek úgynevezett pásztorbotszerű görbülése (45. ábra), mely a parenchima sejtek összeomlásának a következménye (Vanneste és EdenGreen 2000).

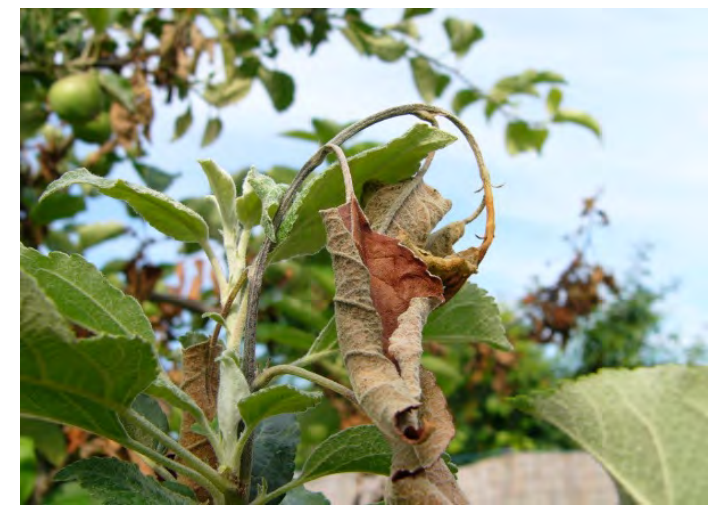

4. ábra A tüzelhalás tünetei fiatal alma (Malus x domestica Borkh. 'Golden') hajtáson (Fotó: Kolozsváriné N.J., 2007, Siófok)

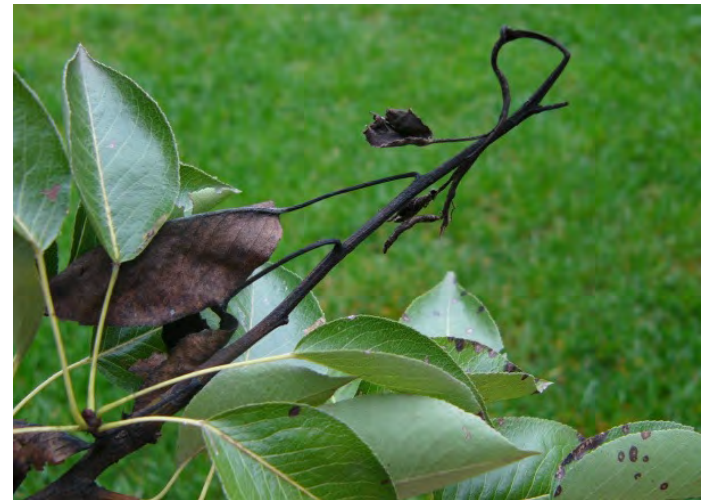

5. ábra E. amylovora okozta hajtásfertőzés tünete körtén (Pyrus x communis L. 'Vilmos') (Fotó: Kolozsváriné N.J., 2007, Siófok)

A fertőzött levelek erei barnulnak, elfeketednek, majd a levelek egésze elhal, de a hajtáson maradnak (6. ábra). 


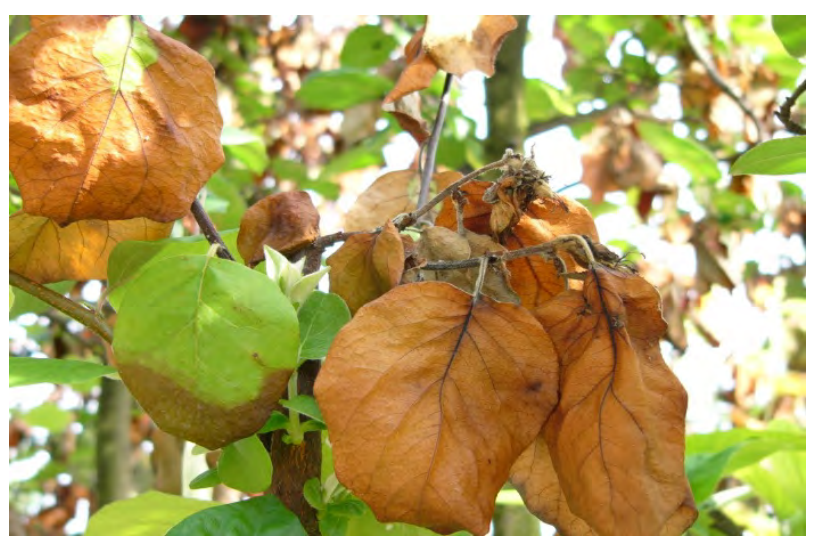

6. ábra E. amylovora-val fertózött birs (Cydonia oblonga Mill.) levelek (Fotó: Kolozsváriné N.J., 2007, Siófok)

A hajtásnövekedés és gyümölcsképződés időszakában nemcsak a folyékony, de a megkeményedett, fonalas szerkezetü, baktériumsejteket tartalmazó nyálkaanyag is inokulumként szolgál elsősorban a másodvirágzatok, zsenge hajtások, gyümölcsök fertőződéséhez (7. ábra). Az érett gyümölcsökön is a fiatal termésekhez hasonló tünetek alakulnak ki, és megfelelően meleg, párás időjárás esetén a paraszemölcsökön keresztül kiváló sűrü, baktériummal telített nedv a gyümölcs felszínén csepp alakban megjelenik (8. ábra) (van der Zwet és Keil 1979). A vegetáció vége felé az idősebb növényi részeken az ág és a törzselhalás tüneteként a háncsszövet felpuhul, vizenyős és ezüstös-barna lesz, majd az elhalt szövetek besüppednek, és az ép és a fertőzött szövetek határán repedés jelentkezik. A rákos sebek szélén a kéreg alatti fás részeken vörösesbarna csíkozottság alakul ki (van der Zwet és Keil 1979). Az így kialakuló újabb üszkös sebekben a baktériumsejtek egy része áttelel, majd a következő év tavaszán új fertőzést indít el.

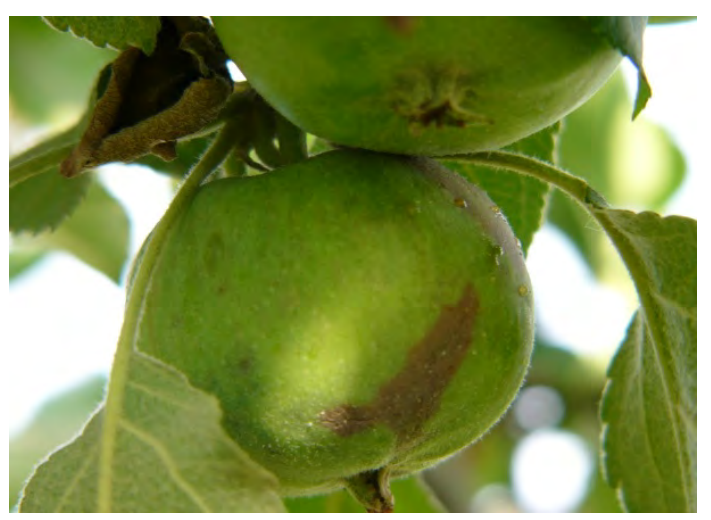

7. ábra A tüzelhalás tünetei alma (Malus $\mathrm{x}$ domestica Borkh. 'Golden') gyümölcsön (Fotó: Kolozsváriné N.J., 2007, Siófok)

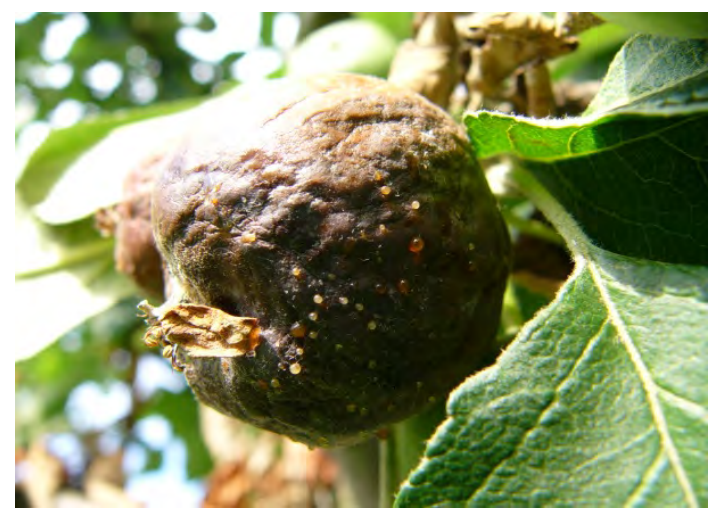

8. ábra Baktériumnyálka cseppek $E$. amylovora-val fertőzött almán (Malus x domestica Borkh. 'Golden') (Fotó: Kolozsváriné N.J., 2007, Siófok) 


\subsection{A KÓROKOZÓ JELLEMZÉSE \\ 3.2.1 ELNEVEZÉSE ÉS RENDSZERTANI BESOROLÁSA}

Az almatermésủek tüzelhalásának kórokozója az Erwinia amylovora (Burrill) Winslow et al. (1920) baktériumfaj, melyet elsőként Micrococcus amylovorus néven Burrill (1882) írt le, majd Bacillus amylovorus (Burr.) (Trevisan 1889), azt követően Bacterium amylovorum (Burr.) (Chester 1897), végül pedig Winslow és mtsai. (1920) nyomán a kórokozó hivatalos neve Erwinia amylovora lett. Aktuálisan a Proteobacteria törzs Gamma Proteobacteria osztályának Enterobacteriales rendjébe, azon belül az Enterobacteriaceae család Erwinia nemzetségébe tartozik (Paulin 2000). Ebbe a nemzetségbe 17 Gram-negatív, mozgékony, aerob - fakultatív anaerob, nem sporuláló faj tartozik (Holt és mtsai. 1994), amelyek ökológiailag közvetlen kapcsolatban állnak a növényekkel (Brenner 1984). Az E. amylovora törzseket három fö csoportba lehet sorolni: Maloideae (Maloideae fajokról izoláltak), Rubus (Rosoideae növényekről izoláltak) és 'Hokkaido' (Japánból, ázsiai körtéről származók), de ezeken belül további alcsoportok léteznek (Momol és Aldwinckle 2000).

\subsubsection{A KÓROKOZÓ FŐBB JELLEMZÖI}

A kórokozó általános tulajdonságait Paulin (2000) összefoglaló munkája részletezi. Az $E$. amylovora mintegy 0,3 $\mu \mathrm{m}$ x 1-3 $\mu \mathrm{m}$ méretü, pálcika alakú, Gram-negatív baktérium, mely 2-7 peritrich flagelluma révén önálló mozgásra képes. Ez a mozgásképesség mesterséges anaerob viszonyok között, megfelelő szénforrás esetén nyilvánul meg (fertőzött növényi szövetek sejtközötti járataiban nem figyeltek meg mozgékony sejteket) és specifikus hőmérséklet- és pHfüggő (optimálisan $20^{\circ} \mathrm{C}, \mathrm{pH} 6,8$ ), kemotaxis által vezérelt. Ilyen pozitív kémiai ingert vált ki például az almavirág nektárjának egyik alkotója, a dikarbonsav is. A kórokozó szaporodása 3$5^{\circ} \mathrm{C}$ és $37^{\circ} \mathrm{C}$ között lehetséges, optimálisan $25-27^{\circ} \mathrm{C}$-on történik (Billing és mtsai. 1961). Tenyésztett kolóniái az alkalmazott táptalaj összetételétől függően eltérő morfológiájúak és színezetűek (Paulin 2000). A baktérium dohánynövény sejtközötti járataiba injektálva hiperszenzitív reakciót vált ki (Hevesi 1996).

A baktériumsejtek poliszacharid burkot választanak ki, melynek felépítésről és a kórokozó patogenitásában betöltött szerepéről Geider (2000) nyújt áttekintést. Az E. amylovora egy összetett (amylovoran) és egy homopolimer (levan) exopoliszacharidot (EPS-t) termel, melyek óvják a baktériumsejtet a gazdasejt védekező mechanizmusaival szemben, védik a kiszáradástól, valamint energiaforrásként is szolgálnak. A baktériumsejtek és EPS együttese alkotta nyálka elősegíti a kórokozó fogékony gazdanövényen való megtelepedését és terjedését (Bennett és Billing 1978). Azok az E. amylovora törzsek, amelyek nem képesek az amylovoran 
szintetizálására nem-patogének (Bernhard és mtsai. 1993, Steinberger és Beer 1988) és nem szaporodnak in planta (Bellemann és Geider 1992), míg a levan hiánya az adott törzs virulenciájára hat negatívan (Geier és Geider 1993). Az amylovoran bioszintézisében nagyszámú gén vesz részt, melyek közül a strukturális gének többségének helyet adó ams jelölésü kromoszómaszakaszt Bugert és Geider (1995) részletesen is vizsgálta. Az E. amylovora eddig tanulmányozott törzsei néhány kivételtől eltekintve egy körülbelül 29 kb hosszúságú, a baktérium patogenitásában szerepet játszó plazmidot (pEA29) hordoznak (Vanneste 1995), mely alapján a kórokozó PCR-rel azonosítható (Bereswill és mtsai. 1992). A pEA29 plazmidon elhelyezkedő PstI fragment ismétlődő régiójának, azaz SSR-ének (rövid szekvencia ismétlődésének) száma alapján különbséget találtak a Magyarországon és Ausztriában károsító E. amylovora izolátumok között (Keck és mtsai. 2002). Végh (2012) számos hazai E. amylovora izolátumról, azok SSR eredményei alapján megállapította, hogy egy változatos, eltérő törzsekből álló populációt alkotnak. Végh (2012), valamint Végh és mtsai. (2014) közölték továbbá, hogy az általuk vizsgált hazai izolátumokhoz, melyek többsége 7-8 SSR számmal rendelkezik, legközelebb a 6-7 SSR számú egyiptomi törzsek állnak. Llop és mtsai. (2006, 2011) kimutatták, hogy az általuk leírt és jellemzett 65,8 kb hosszúságú pEI70 elnevezésủ, szintén a kórokozó virulenciájára ható plazmid több európai országból származó E. amylovora törzsben fellelhető, míg az Európán kívüli törzsekben nem.

\subsubsection{GAZDAKÖRE}

Noha az E. amylovora egyetlen növénycsalád (Rosaceae) kórokozójaként ismert, a családon belül széles gazdakörrel rendelkezik; mind a négy alcsalád összesen 40 nemzetségének körülbelül 200 faján idézett már elő tüzelhalásos tüneteket (van der Zwet és Keil 1979). A kórokozó gazdasági jelentőségét az adja, hogy képes megfertőzni a Maloideae (Pomoideae) alcsaládba tartozó gyümölcstermő fajokat [alma (Malus x domestica), körte (Pyrus communis), birs (Cydonia oblonga), naspolya (Mespilus germanica), japán naspolya (Eriobotrya japonica)]. Egyéb jelentősebb gazdanövényei is a Maloideae alcsaládból kerülnek ki: a japánbirs (Chaenomeles lagenaria), a berkenye (Sorbus), a galagonya (Crataegus), a tüztövis (Pyracantha), a madárbirs (Cotoneaster) nemzetség tagjai, valamint a sztranvézia (Stranvaesia davidiana), a fanyarka (Amelanchier) és a korallberkenye (Photinia). A Rosoideae alcsaládon belüli fő gazdanövénye a málna (Rubus idaeus) (Starr és mtsai. 1951) és a tüskétlen szeder ( $R$. rusticanus var. inermis) (Evans 1996), de beszámoltak már japán rózsa természetes fertőzöttségéről is (Vanneste és mtsai. 2002). A Rubus fajokról izolált törzsek (Heimann és Worf 1985) gazdaspecifikusak, nem fertőzik az almát és a körtét. A kórokozó az Amygdaloideae (Prunoideae) alcsaládon belül az európai szilvát (Prunus domestica) (Vanneste és mtsai. 2002, 
Végh 2012, Végh és mtsai. 2012a, 2012b), a japán szilvát (Prunus salicina) (Mohan és Thomson 1996, Rosen és Groves 1928) fertőzi, továbbá kajszin (Prunus armeniaca) is előfordult már Csehországban (Korba és Sillerova 2010), illetve Magyarországon (Végh és Palkovics 2013). Mohan (2007) szilva és kajszi hibridjéről (Pluot®) azonosította. A Spiraeaoidae alcsaládba tartozó gazdanövényei közül például a hólyagvesszőt (Physocarpus sp.) (van der Zwet és Keil 1979) vagy a mesterségesen fertőzhető kerti gyöngyvesszőt (Spiraea vanhouttei) (Rosen és Groves 1928) lehet megemlíteni.

\subsection{VÉDEKEZÉSI LEHETŐSÉGEK, KUTATÁSI IRÁNYOK}

Az almatermésűek tűzelhalása elleni hatékony védekezés jelenleg nem megoldott, ezért különösen fontos mind a mai napig a különböző alapvető védekezési eljárások együttes alkalmazása, kiegészítve azt az aktuális növényvédőszeres és a biológiai védekezés lehetőségeivel (Németh 1997). Azaz az Erwinia amylovora elleni küzdelem során is az integrált növényvédelmi szempontokat javasolt figyelembe venni (Steiner 2000).

\subsubsection{NÖVÉNY-EGÉSZSÉGÜGYI SZABÁLYOK, AGROTECHNIKAI MÓDSZEREK}

A kórokozó elleni védekezésben elengedhetetlen az alapvető növény-egészségügyi rendszabályok követése, így a fertőzésmentes szaporítóanyag előállítása [például hőkezeléssel (Keck és mtsai. 1990)] és forgalmazása.

Németh (1997) részletesen szemlélteti a követendő agrotechnikai eljárásokat. Metszést kizárólag a növényi nedvkeringést megelőzően szabad végezni, kerülve az erőteljes visszavágást, ami intenzív hajtásnövekedést indukálna. Ugyanezen okból különösen ügyelni kell az optimális mennyiségű nitrogén-utánpótlásra. A fertőzött növényi részeket, a gallyakon, ágakon kialakult áttelelő fekélyes sebeket, fertőzést mutató virágokat, hajtásokat, vesszőket, gallyakat és ágakat rendszeresen el kell távolítani ép szövetrésszel együtt. Ez a fertőzött hajtások esetében azt jelenti, hogy 40-60 cm-t a tünetmentes részből is le kell metszeni. A folyamat során elengedhetetlen (lenne) a vágószerszám megfelelő szerekkel (Sobiczewski és mtsai. 1997) való gondos és folyamatos fertőtlenítése. A sebfelületek megfelelő kezelése fertőtlenítő oldat, majd sebzáró készítmény kijuttatásával történhet. 


\subsubsection{A FERTŐZÉS ELŐREJELZÉSE}

Különös tekintettel arra, hogy a betegség tüneteinek előfordulási gyakorisága és súlyossága évenként és ültetvényenként változhat (Bubán és Dorgai 2003), a védekezés alappillére a fertőzésveszély előrejelzése, mely alapján a megfelelő védekezés időzíthető, s egyúttal elkerülhetők azok a kezelések, amelyek az inokulum felszaporodásához és a fertőzés létrejöttéhez kedvezőtlen időjárási viszonyok esetén feleslegessé válnak (Németh 1997). Több előrejelzési modell ismert (Billing 2000, Bubán és Dorgai 2003), közülük is a legelterjedtebbek az USA-ban kidolgozott és alkalmazott Maryblyt ${ }^{\mathrm{TM}}$ (Steiner 1990), a Couger blight (Smith 1993) és az Európában kifejlesztett Billing-féle rendszer (Billing 1980a, 1980b, 1984) átdolgozott változata a Billing's integrated system, BIS (Billing 1996). Ezek a rendszerek a virágzás időszaka alatt mérik az időjárási adatokat és meghatározott kritériumok [Steiner 1990 (a 3.1.3 fejezetben tárgyalva), Takács 2013] teljesülése esetén prognosztizálják a fertőzési veszély kialakulását. Magyarországon a Maryblyt ${ }^{\mathrm{TM}}$ számítógépes rendszeren alapuló megfigyelő és előrejelző hálózat lett kiépítve.

\subsubsection{KÉMIAI VÉDEKEZÉS}

Az E. amylovora ellen jelenleg hazánkban engedélyezett készítmények (Ocskó és mtsai. 2014) közül a kémiai növényvédő szerek egy kivétellel (Aliette 80 WG) mind rézkészítmények, melyek hatóanyaga rézhidroxid, rézoxiklorid, néhány szernél mankoceb és olaj hatóanyaggal kombinálva. Alkalmazásuk az epifiton baktériumpopuláció gyérítése céljából a lombhullás után és a nyugalmi időszak végén, a megmetszett állományra irányuló lemosó permetezés formájában javasolt. Egyéb kijuttatásukkor ugyanis számolni kell a fajtaérzékenység és az időjárási tényezők által befolyásolt fitotoxicitással. A szisztemikus hatásmechanizmusú, foszetil-Al hatóanyagú Aliette 80 WG szert Sobiczewski és mtsai. (1997) a rézkészítményeknél hatékonyabbnak találták az E. amylovora ellen. A foszetil-Al a növény védekező mechanizmusát stimulálja, ezért annak kijuttatását a növény megfelelő fenológiai fázisához kell időzíteni (Steiner 2000).

\section{Antibiotikumok használata}

Az antibiotikumok - azaz az olyan, mikroorganizmusok által termelt szerves anyagok, melyek szelektíven gátolják más mikroorganizmusok szaporodását - alkalmazása a bakteriális növényi kórokozók, köztük az E. amylovora ellen az 1950-es években kezdődött az addig nehezen gyógyítható humán betegségek sikeres kezeléseinek folyományaként. Az almatermésűek tűzelhalásának kórokozója számos antibiotikumra érzékeny, de ezek közül csupán a sztreptomicin, az oxitetraciklin és a kasugamicin felelt meg az in vivo alkalmazás 
követelményeinek (Psallidas és Tsiantos 2000). A virágfertőzés ellen az ezidáig leghatékonyabb baktericidnek az aminoglikozidok csoportjába tartozó sztreptomicin (Schatz és mtsai. 1944) bizonyult, azonban növényvédelmi célú használata számos országban, így (2004. január 1-től) hazánkban sem engedelyézett (Takács 2013). A kasugamicin hatóanyagú Kasumin 2L 2008 óta csak szükséghelyzeti engedéllyel alkalmazható almatermésüek kultúrájában Magyarországon (https://novenyvedoszer.nebih.gov.hu/Engedelykereso/kereso.aspx). Az antibiotikumok betiltásának az egyik oka a sztreptomicinre ellenálló E. amylovora törzsek megjelenése volt, majd az ennek következtében kialakuló félelem az antibiotikumok növényvédelmi célú felhasználásából fakadó humán egészségkárosodás és környezetszennyezés lehetőségétől, melyet nemcsak az E. amylovora, de a kijuttatás helyszínén levő növény felületén, a környező talajban vagy vízben elöforduló egyéb mikroorganizmusokban, köztük esetlegesen humán-, illetve állatbetegségeket előidéző kórokozókban kifejlődő sztreptomicin-rezisztencia (Jones és Schnabel 2000) jelent. Sztreptomicin-rezisztens E. amylovora törzseket elsősorban azokról a területekről izoláltak, ahol a védekezés alapját a sztreptomicin hatóanyagú készítményekkel való rendszeres időközönként végzett nagy számú permetezés jelentette, így az Amerikai Egyesült Államok nyugati részén (Moller és mtsai. 1981). Elsőként kaliforniai körte ültetvényből izoláltak sztreptomicin-ellenálló E. amylovora törzset 1971-ben (Miller és Schroth 1972), majd Oregon és Washington államokból (Coyier és Covey 1975), Missouriból (Shaffer és Goodman 1985) és Michiganből (Chiou és Jones 1991). Amerikán kívül Mexikóban (de León-Door és mtsai. 2013), Egyiptomban (El-Goorani és mtsai. 1989), Új-Zélandon (Thomson és mtsai. 1993) és Izraelben (Manulis és mtsai. 1996) is találtak sztreptomicin-rezisztens E. amylovora törzseket. Azonban előfordultak spontán rezisztens törzsek olyan ültetvényeken (USA) is, ahol sztreptomicinnel nem permeteztek (Hevesi M. személyes közlés).

A sztreptomicin tűzelhalás elleni használatának korlátozásához a klinikai céllal alkalmazott baktériumok felé irányuló feltételezett horizontális géntranszfer (Seveno és mtsai. 2002) miatti aggodalom is hozzájárult. Ugyanakkor Rezzonico és mtsai. (2009b) kimutatták, hogy a növényvédelemben használt sztreptomicin készítmények nem hordozzák az előállításukhoz használt Streptomyces griseus ssp. griseus baktériumból származó rezisztenciagéneket (Ohnishi és mtsai. 2008) s ezáltal nagyon valószínütlen, hogy közvetlen forrásként szolgálnának ezen géneknek az ültetvény mikrobáiba vagy az ott dolgozók szervezetébe történő jutásához. Az utóbbi időben több kutatás (Duffy és mtsai. 2011, Stockwell és Duffy 2012, Yashiro és McManus 2012) eredménye is azt igazolta, hogy a sztreptomicin tüzelhalás elleni alkalmazása csupán kismértékű környezeti hatással bír.

Böszörményi és mtsai. (2009) beszámoltak egy ígéretes, új, széles hatásspektrumú, bizonyos entomopatogén nematódákkal szimbiózisban élő entomopatogén baktériumok 
(Xenorhabdus budapestiensis és X. szentirmaii) által termelt antibiotikumról, mely kísérletükben igen hatékonynak bizonyult az E. amylovora ellen.

\section{Egyéb kémiai vegyületek}

A sztreptomicin, illetve a rézkészítmények alternatívájaként számos, a tủzelhalás ellen hatásos vegyületről számolhatunk be (Psallidas és Tsiantos 2000). Így a növényi szisztemikus szerzett rezisztenciát (SAR-t) indukáló benzothiadiazol $\left(\operatorname{Bion}^{\mathrm{TM}}{ } \operatorname{Actigard}^{\mathrm{TM}}\right)$, a gibberellin bioszintézisének gátlása révén növekedési retardáns prohexadion-Ca (Regalis ${ }^{\mathrm{TM}}$, Apogee ${ }^{\mathrm{TM}}$ ), a flumequin (Firestop ${ }^{\mathrm{TM}}$, Fructil ${ }^{\mathrm{TM}}$ ), az E. amylovora harpin fehérje $\left(\right.$ Messenger $^{\mathrm{TM}}$ ) vagy az oxolinsav (Starner ${ }^{\mathrm{TM}}$ ) hatóanyagokról, bár Kleitman és mtsai. (2005) kimutatták, hogy ez utóbbival szemben már kialakult rezisztencia. A Magyarországon előállított Biomit Plussz ${ }^{\circledR}$ lombtrágya a növények kondicionálása révén fokozza azok betegségekkel szembeni ellenállóságát (Bubán és mtsai. 2007). Ismeretesek olyan fertőtlenítő szerek (Psallidas és Tsiantos 2000), melyek gátolni tudják a kórokozónak metsző szerszámokkal, az ültetvényben dolgozók testéről, ruházatáról, vagy a leszüretelt gyümölcs felületéről történő terjedését.

\subsubsection{ALTERNATÍV VÉDEKEZÉSI LEHETŐSÉGEK}

\section{Rezisztencia-nemesítés}

\section{Klasszikus növénynemesítés}

Az 1970-es évektől kezdődően a különböző fajták fogékonysági kategóriákba sorolására épülve számos nemesítési program került kidolgozásra körte, alma, tüztövis, galagonya és madárbirs esetében (van der Zwet és Keil 1979). Mivel a világszerte termesztésbe vont gazdanövényfajok fajtáinak szinte mindegyikét képes az E. amylovora megfertőzni, de azok egy része eltérő mértékben türi azt, valójában csupán toleranciáról lehet szó e növényi betegség esetében (Németh 1997). Ezért is különösen fontos a fajták tüzelhalással szembeni fogékonysági csoportokba való sorolása különböző (hajtás-, virág- és gyümölcs-) fertőzési kísérletek eredményei révén. Hazánkban Honti (2011) és Végh (2012) végzett ilyen irányú kísérleteket körtefajták esetében. Továbbra is jelentős nemesítési munka folyik az USA-ban, Kanadában, Franciaországban, Olaszországban és Németországban (például a pillnitzi Pi- és Realmafajták $^{\circledR}$ ) (Lespinasse és Aldwinckle 2000). Hazánkban az 1990-es évek eleje óta végeznek sikeres nemesitési célú kutatásokat (multirezisztens alma MR- sorozat) hazai történelmi alma- és körtefajták bevonásával a Budapesti Corvinus Egyetem, Kertészettudományi Kar, Gyümölcstermő Növények Tanszékén (Honty és mtsai. 2004, Király és Tóth 2009, Tóth 2005, Tóth és mtsai. 2005). Ennek eredményeként a közelmúltban államilag elismerésre is került négy 
almafajta ('Artemisz', 'Cordelia', 'Hesztia', 'Rosmerta'), melyek amellett, hogy rezisztenciát mutatnak az alma ventúriás varasodásával és az almalisztharmattal szemben, hajtásaik rezisztensnek, illetve mérsékelten rezisztensnek mondhatók az almatermésűek tüzelhalása ellen (Tóth és mtsai. 2012).

\section{Transzgénikus fajták}

Egyes, az E. amylovora-val szemben rezisztenciát biztosító gének - elsősorban az EPSdepolimeráz, lizozim, attacin és cecropin, gének - alma-, illetve körte növényekbe biotechnológiai úton történő beépítése és expresszáltatása, vagy a bakteriális DspE effektorokkal kölcsönhatásba lépö növényi (Malus) proteineket kódoló (DIPM) gének lecsendesítése (Borejsza-Wysocka és mtsai. 2006) lehetséges védekezési stratégiát jelenthetnek a tüzelhalás elleni harcban (Aldwinckle és Malnoy 2009, Broggini és mtsai. 2014, Malnoy és mtsai. 2007, Norelli és Aldwinckle 2000).

Az exopoliszacharid depolimeráz növényekben való kifejeztetésének a célja az, hogy lebontásra kerüljön az E. amylovora patogenitásában szerepet játszó EPS burkot alkotó fő komponens, az amylovoran, mely által a növény védekező mechanizmusai hatékonnyá válhatnak a kórokozóval szemben (Geider 2000), míg a lizozim enzim a sejtfal elvékonyításával, a gazdabaktérium lízisét, felbomlását eredményezi (Norelli és Aldwinckle 2000). A ФEa1h E. amylovora bakteriofág genomjának egy 3,3 kb hosszúságú szakaszából származó EPSdepolimerázt ( $d p o$ ) (Hartung és mtsai. 1988, Kim és Geider 2000), illetve lizozim enzimet (lyz) (Kim és mtsai. 2004) kódoló gének hatékonynak bizonyultak a kórokozó ellen. A dpo gén alma (Hanke és mtsai. 2003, Süle és mtsai. 2002), illetve körte (Malnoy és mtsai. 2005) növényekben történő expressziója a betegség tüneteinek csökkenését eredményezte. Az Escherichia coli T4 bakteriofág lizozim enzimjét kódoló gént tartalmazó transzformáns 'Galaxy' (Ko és mtsai. 2002), illetve 'Royal Gala' (Aldwinckle és mtsai. 2003) alma növények fokozott rezisztenciája is ismert.

A cecropinok és az attacinok egyaránt olyan antibakteriális hatással bíró lítikus peptidek, melyeket eredetileg egy észak-amerikai molylepke, a Hyalophora cecropia bábjából izoláltak (Hultmark és mtsai. 1980, 1983). A cecropinok hatásmechanizmusára jellemzö, hogy elöször pórusokat képezve a sejtmemránban a sejt felbomlását idézik elő (Christensen és mtsai. 1988). Norelli és mtsai. (1999) a cecropin B két szintetikus analógját, az SB-37, illetve a Shiva-1 peptideket kódoló, míg Liu és mtsai. (2001) a cecropin $S B-37$ gén módosított változatát, a cecropin MB-39 gént tartalmazó különböző bináris vektorkonstrukciókkal transzformált 'Royal Gala' fajtájú almanövények esetében találtak a nem transzformáns kontrollhoz képest ellenállóbbnak bizonyult vonalakat. Az attacinok antibakterális hatása abban áll, hogy gátolják a 
Gram-negatív baktériumok külső memránfehérjéjének szintézisét (Carlsson és mtsai. 1998). Az attE gént tartalmazó tanszgénikus M26 almaalanyok (Norelli és mtsai. 1994), 'Galaxy' almafajták (Ko és mtsai. 2000) és 'Passe Crassane' körtefajták (Reynoird és mtsai. 1999) esetében is a tüzelhalás tüneteinek a kontroll növényekhez viszonyított szignifikáns csökkenéséről számoltak be a transzformáns klónok egy részénél.

A többek között Koch és Kogel (2014) által átfogóan tárgyalt géncsendesítés vagy nukleinsav alapú növényi immunitás (,host-induced gene silencing”) folyamata révén különböző génkonstrukciókkal transzformált 'Galaxy' alma növények hajtásainak E. amylovora-val történő inokulációját követően a transzformáns vonalak egy részének fokozott ellenállóságát tapasztalták (Borejsza-Wysocka és mtsai. 2006). A rezisztencia háttere abban áll, hogy normál esetben az $E$. amylovora betegség specifikus génje $(d s p \mathrm{E})$ által kódolt effektor protein négy specifikus kinázzal (DIPM gének által kódolt DspE enzimekkel kölcsönhatásba lépő növényi (Malus) proteinek) kölcsönhatásba lépve hozzájárul a betegség kialakulásához. Így a DIPM géneket lecsendesítve meggátolható az általuk kódolt fehérjék DspE enzimekkel való kölcsönhatása.

\section{Biológiai védekezés}

A már korábban említett sztreptomicin-rezisztens E. amylovora törzsek megjelenése és az annak okán teret hódító, az antibiotikumok növényvédelmi célú használatának elkerülését támogató nézet elősegítette többek között különböző biológiai védekezési stratégiák kidolgozását. A tűzelhalás elleni biológiai védekezési módok kutatása és azok eredményeképpen kifejlesztett, gyakorlatban alkamazható készítmények vizsgálata az utóbbi időszakban számos tudományos cikk témájául szolgált, melyekről átfogó képet Johnson és Stockwell (2000), Vanneste (2011) és Zeller (2006) munkáiból nyerhetünk.

\section{Antagonista szaprofiton baktériumok}

A mikroorganizmusokkal történő biológiai védekezés ebben az esetben úgy valósul meg, hogy ezek a baktériumok a bibe felszínén az E. amylovora-t megelőzően elszaporodva a kórokozó epifiton populációjának növekedését gátolják (Johnson és mtsai. 1993, Wilson és mtsai. 1992), ezáltal lecsökkentik mind az elsődleges, mind a további virágfertőzés valószínűségét. Ezt a hatásmechanizmust antibiózis is kiegészítheti (Stockwell és mtsai. 2002, Zeller 2006).

A legkorábbtól és az eddig talán legátfogóbban vizsgált antagonista mikroorganizmus törzsek a Pantoea vagans (syn. Pantoea agglomerans, Erwinia herbicola) csoportba (Rezzonico és mtsai. 2009a) tartoznak. Közülük is a nemzetközileg legismertebbek az amerikai EhC9-1 
[BlightBan ${ }^{\circledR}$ C9-1 (USA), Bloomtime BiologicalTM (Új-Zéland)], a P10c [Blossom Bless ${ }^{\mathrm{TM}}$ (ÚjZéland), Poma Vita ${ }^{\mathrm{TM}}$ (Olaszország)] és az Eh252 törzs (Vanneste 2006, Zeller 2006). A Magyarországon almalevélről izolált $P$. agglomerans HIP32 izolátum (Hevesi és Al-Arabi 1999) az E. amylovora-val szembeni hatékonyságát is igazolta (Al-Arabi 2002, Bubán és mtsai. 2007, Hevesi és mtsai. 2006b). Hevesi és mtsai. (2008) kísérletükben biokémiai és molekuláris módszerekkel több $P$. agglomerans izolátummal összehasonlítva részletesen jellemezték a $P$. agglomerans HIP32-t, továbbá kimutatták, hogy genomjának molekuláris vizsgálata alapján 9596\%-os homológiát mutat (16S rRNS gén) más Pantoea fajokkal, illetve 99\%-ban megegyezik (rpoB gén) a Klebsiella pneumoniae fajjal.

Az első, tüzelhalás elleni biokontroll ágens a Pseudomonas fluorescens A506 jelzésü törzs volt (Lindow és mtsai. 1996, Vanneste 2006), mely 1995-től került kereskedelmi forgalomba (USA) BlightBan ${ }^{\circledR}$ A506 néven (Johnson és Stockwell 2000). Tüzelhalás elleni hatékonyságát a $P$. vagans C9-1 törzzsel körte- és almavirágokon végzett szabadföldi kísérletekben összevetve (Stockwell és mtsai. 2010) a C9-1 eredményesebbnek bizonyult. A két törzs együttes alkalmazása a vártnál kevésbé volt hatékony, melynek oka e törzsek hatásmechanizmusának inkompatibilitásában keresendő.

Igazolt antagonista hatással bír a gram pozitív Bacillus subtilis BsBD 170 (BioPro ${ }^{\circledR}, 2001$, Németország), QST713 (Serenade ${ }^{\circledR}$, USA), illetve a BS-F3 (Alexandrova és mtsai. 2002) baktériumtörzs és egy másik epifiton baktérium, a Rhanella aquatilis Ra 39 törzse (Laux és mtsai. 2003) is.

A különböző antagonista baktériumok hatékonyságának összehasonlítását tárgyaló számos munka közül kiemelkedik Sundin és mtsai. (2009) több évre kiterjedő, átfogó kísérletsorozata.

\section{Egyéb mikroorganizmusok}

A tüzelhalás elleni biológiai védekezés egy másik kutatási irányát képezi az úgynevezett genetikailag jellemzett, avirulens inszerciós mutáns Erwinia amylovora törzsek esetleges gyakorlati felhasználása (Tharaud és mtsai. 1997). Ezek a transzpozon inszercióval előállított E. amylovora mutánsok két csoportot képeznek; az egyikben az inszerciók a kórokozó genomjában a nem-gazda növényeken hiperszenzitív reakciót (HR-t), míg gazdanövényeknél patogenitást kiváltó hrp géncsaládot (Steinberger és Beer 1988), illetve egy részük azon belül egy $d s p$ (betegség specifikus), később hrm (hiperszenzitív választ moduláló) elnevezésü alcsoportot, a másikban az amylovoran bioszintéziséért felelős ams régiót (Belleman és Geider 1992, Tharaud és mtsai. 1994) érintik. Ez utóbbi Ams ${ }^{-}$muntánsokra a kórokozó patogenitásában és virulenciájában meghatározó szerepet játszó extracelluláris poliszacharid (EPS) - elsősorban amylovoran - termelésének hiánya jellemző (Tharaud és mtsai. 1997). A 
növényvédelmi alkalmazásuk azonban megfontolandó, mert bár az EPS burkot nem termelö, avirulens E. amylovora mutánsok fág rezisztensek (Roach és mtsai. 2011), az egyéb típusú, nem EPS- avirulens mutánsok esetében elvileg megvan a kockázata annak, hogy a lizogén fágok által indukált transzdukció révén kialakul egy revertáns mutáns, virulens populáció.

Az E. amylovora-val szembeni antagonista hatással kapcsolatos, élesztőgombákkal végzett kutatások (Kunz és mtsai. 2004, 2011) is bíztató eredményeket szültek. Aureobasidium pullulans (Blossom Protect ${ }^{\mathrm{TM}}$, USA) és Metschnikowia pulcherrima, valamint Cryptococcus spp. élesztőgomba törzsekkel végzett kísérletekben (Jelkmann és Lindner 2008, László 2008, Pusey és mtsai. 2009, Seibold és mtsai. 2006) kimutatták e fajok E. amylovora-val szembeni antagonista hatását. A hazánkban is alma, körte, birs, és naspolya kultúrákban engedélyezett (Ocskó és mtsai. 2014) Blossom Protect ${ }^{\mathrm{TM}}$ nevü készítményt németországi szabadföldi kísérletekben a sztreptomicinhez hasonló hatásfokúnak találták (Ertl és mtsai. 2007).

Bakteriofágok használata is sok esetben bizonyult már eredményesnek (a téma részletes tárgyalását lásd a 3.4, 3.5 és 3.6 fejezetben).

\section{Természetes eredetü anyagok}

Növényi kivonatok és illóolajok

Az 1980-as évek végétől kezdődően számos növényi kivonat és illóolaj antibakteriális hatását vizsgálták az E. amylovora ellen. Mosch és mtsai. (1989) kísérletei alapján a fekete dió (Juglans nigra), ecetfa (Rhus typhina), közönséges borbolya (Berberis vulgaris), közönséges mahónia (Mahonia aquifolium) és a fokhagyma (Allium sativum) kivonatai bizonyultak a leghatékonyabbaknak. A borostyán (Hedera helix) kivonatának hatásossága is igazolást nyert (Baysal és mtsai. 2002, Mosch és mtsai. 2000).

Az E. amylovora ellen igazolt és jelentős antimikrobiális hatással bír többek között a szurokfü (Origanum vulgare), borsikafü (Satureja hortensis), kerti kakukkfü (Thymus vulgaris) és a Thymbria spicata var. spicata, egy másik kakukkfüfaj illóolaja (Basim és mtsai. 2000, Hevesi és mtsai 2006a, Kokoskova és mtsai. 2011, Scortichini és Rossi 1989). Ez utóbbi növényi illóolaj két készítmény (Aksebio 2, Bio Zell-2000B) hatóanyagát is képezi (Zeller 2006).

\section{Ásványi porok}

Több, a biogazdálkodásban használt kőpor alapú készítmény németországi tesztelése során kiderült, hogy a Myco-Sin és Ulmasud készítmények ásványi vegyületei igen hatékonyak lehetnek a tüzelhalás ellen (Roemmelt és mtsai. 1999). Nyugat-Virginiában (USA) egy másik 
vegyülettel, a kaolinnal alma- és körteültetvényekben végzett virágkezelések a virágfertőzés mértékének szignifikáns lecsökkenését eredményezték (Zeller 2006).

\subsection{A BAKTERIOFÁGOK JELLEMZÉSE}

\subsubsection{BEVEZETÉS}

A bakteriofágok vagy röviden fágok baktériumokat fertőzni képes vírusok, melyeket a bioszféra egyik leggyakoribb, legszéleskörübben elterjedt és legváltozatosabb szervezeteként tartanak számon (Adams 1959, Kutter és Sulakvelidze 2005). Egyes bakteriológusok már az 1890-es években felfigyeltek egy ismeretlen baktériumgátló ágensre, de senki sem tisztázta az ágens pontos mibenlétét (lásd pl. Sulakvelidze és mtsai. 2001). A fágokat a 20. század elején fedezték fel vagy pontosabban ekkor kerültek újra felfedezésre egymástól függetlenül Twort (1915) és d'Herelle (1917) által. Tudományos munkájukban mindketten bakteriális lízisből származó szürhető ágensekről számoltak be, de d’Herelle volt az, aki rájött arra, hogy baktérium vírusokat fedezett fel, melyeknek a bakteriofág nevet adta (eredetiben: „un bactériophage obligatoire") (Summers 2005).

\subsubsection{A BAKTERIOFÁGOK BIOLÓGIÁJA}

Maga a fág, a virion részecske, az adott fágra jellemzően DNS-ből, ritkábban RNS-ből áll. Ezt kívülről egy fehérjeburok, kapszid övezi, mely egyrészt védi az egy lineáris vagy cirkuláris kromoszómát tartalmazó haploid fággenomot a fág életciklusának extracelluláris szakaszában a különféle nukleinsavbontó enzimektől, hozzájárul a virion fogékony baktériumsejthez történő tapadásához, és azt követően annak a sejt citoplazmájába juttatásához (Gill és Abedon 2003). Életciklusuk több alaplépésre különíthető el. Az első a fent említett extracelluláris fázis, mely során a fág várakozik, míg alkalmas gazdasejtre nem lel. Ezt követi egy infekciós szakasz, melyben a fág fiziológiai folyamatainak nagy része lejátszódik (Guttman és mtsai. 2005), úgymint a megtapadás és a penetráció, a fág nukleinsav-tartalmának baktériumsejtbe való behatolása (Molineux 2006), melyet gyorsan követ a gazdasejt nukleinsav- és fehérjeszintézisének felborulása és a sejt a fággenom hatására virális alkotóelemek termelésébe kezd, majd végül az új vírusrészecskék összeszerelődnek. Az adott fágtól függően ezek a virionok aztán vagy akkumulálódnak a baktérium citoplazmájában - az úgynevezett lítikus fágok esetén -, vagy, mint a fonalas fágoknál a sejt folyamatosan új vírusrészecskék kiválasztására kényszerül, saját membránját adva burokként. Az infekció - rendszerint fág-indukált bakteriális lízis révén - a fág részecskék baktériumsejtből való kiáramlásával ér véget, melyet követően kezdetét veszi egy újabb extracelluláris szakasz (Abedon 2014, Gill és Abedon 2003). 
A lítikus fágok, melyek esetében az érett virionok csak a gazdasejt teljes felbomlása (lízise) után szabadulnak ki a baktériumból két csoportra oszthatók: az obligát lítikus vagy virulens, illetve a mérsékelt vagy temperált fágokra (pl. P1 Escherichia coli fág). Csak ez utóbbiak képesek úgynevezett lizogén életciklusra, amikor is a penetrációt követően rövid időn belül leáll az infekció folyamata és a legtöbb esetben a fág örökítőanyaga profágként a baktériumsejt kromoszómájába integrálódik és egyfajta nyugalmi állapotban a gazdabaktériummal együtt replikálódik. A gazdaszervezet anyagcseréjében bekövetkező változások és magának a fertőzést indukáló fágnak a sajásosságai révén az endogén fág később aktivizálódhat, mely a baktériumsejt líziséhez vezet (Gill és Abedon 2003, Putnoky és Hoffmann 2007).

A fágokat gazdaspecifitás jellemzi. Gazdakörük (host range) azt jelzi, hogy az adott fág mely baktériumtörzsön képes szaporodni (Putnoky és Hoffmann 2007). A fág táptalaja a megfelelő gazdabaktérium. A fágokkal folyó vizsgálatokban egy lágyabb, úgynevezett fedőagar rétegbe belekeverik a baktériumot és a megfelelően higított fágot, mely a növekvő baktériumgyepen szaporodni kezd. A fágpopuláció lágyagar rétegben történő növekedése tarfoltok (plaques vagy magyarul plakkok) formájában figyelhető meg. Ezek a fág által indukált, bakteriális lízis előidézte terjedő régiók egy-egy fág infekció több fertőzési cikluson keresztül kialakuló következményei. A plakk morfológiájának meghatározó bélyege a méret és a tisztaság foka. A nagy plakk gyors, a kicsi lassú fágszaporodásra utal. Amennyiben a fág nem képes minden baktériumot elpusztítani a tarfolt területén akkor zavaros (turbid plaque), ha képes erre, akkor tiszta plakkot (clear plaque) ad (Gill és Abedon 2003, Putnoky és Hoffmann 2007). A tiszta plakk a fág által kódolt lizin hatására alakul ki, nem tartalmaz élő bakteriális sejteket (Hartung és mtsai. 1988). A bakteriofágok gazdakörének vizsgálata nem csupán egy adott fágizolátum, illetve törzs egyik meghatározó bélyegét írja le, de ennek során történik a kórokozó baktériumra specifikus fágok elsődleges szelekciója. E teszt során kiválaszthatók a fágok közül azok, amelyek a legtöbb vizsgált patogén törzset képesek lizálni a baktériumgyepen tiszta plakkot képezve, ugyanakkor más, nem cél baktériumon nem alakítva ki tarfoltokat. Az ilyen lítikus fágok lehetnek alkalmasak fágterápiás célra, míg a baktériumrétegen zavaros plakkot képező temperált fágok, melyek felhasználását el kell kerülni, kiszürendők a vizsgált fágok közül.

\subsubsection{RENDSZERTANI BESOROLÁSUK}

A bakteriofágok rendszerezésének alapja a morfológiájuk - a farokkal rendelkező fágok esetében a fej és a farok mérete, illetve típusa a meghatározó bélyeg - és a nukleinsav típusa, mely lineáris vagy körkörös elrendezésủ, egy - vagy kétszálú RNS, illetve DNS lehet. A rendszerezéssel a Bacterial Virus Subcommittee of the International Committee on Taxonomy of 
Viruses (ICTV) foglalkozik (Maniloff és Ackermann 1998). A farokkal és kettős szálú lineáris DNS-sel rendelkező, Caudovirales rendbe sorolt fágok (Ackermann 1998, 2007) adják az irodalomból ismert fágok döntő többségét. A rendbe a Myoviridae (burok nélküli, összehúzódó farok, pl. T4 fág), a Siphoviridae (burok nélküli; hosszú, nem-összehúzódó farok, pl. $\lambda$ fág) és a Podoviridae (burok nélküli; rövid, nem-összehúzódó farok pl. T7 fág) családok tartoznak (Mc Grath és van Sinderen 2007).

\subsubsection{ALKALMAZÁSI TERÜLETÜK}

\section{Fágterápia}

A bakteriofágok humán terápiás felhasználása 1919-től (Summers 1999) vette kezdetét és a fágterápiát Oroszországban, valamint Grúziában (G. Eliava Institute of Bacteriophages, Microbiology and Virology, Tbilisi) azóta is széles körben kutatják és alkalmazzák (Kutter 2009). Noha a korai, nem megfelelően kontrollált kísérletek nem igazolva a várakozásokat az antibiotikumok térhódításával karöltve nyugaton visszavetették a fágterápiás kísérleteket, mára a fágok számos, humán- és állatgyógyászatban (Abedon és mtsai. 2011, Haq és mtsai. 2012, Johnson és mtsai 2008, Kutateladze és Revaz 2010, Milch 2000, Sulakvelidze és mtsai. 2001), valamint a növényvédelemben (lásd 3.5 fejezet) alkalmazott, eredményes felhasználása ismert.

\section{Genetikai és biológiai alkalmazások}

A molekuláris genetikában ismert általános bakteriális transzdukció jelensége (Lederberg és mtsai. 1951) - azaz amikor a fág bármely baktériumgént képes átvinni egyik baktériumsejtből a másikba - úgynevezett finomtérképezésre használható (Putnoky és Hoffmann 2007).

A fág „display” molekuláris módszerénél, melyet új tulajdonságokkal bíró polipeptidek szintetizálására használnak, az adott polipeptidet kódoló DNS-t a fág köpenyfehérje génjeivel fúzionálják, majd az adott fehérjét a fág felületén expresszáltatják (Smith 1985).

A járványtani vizsgálatoknál a fágtipizálás vagy fágtípus meghatározás során fertőző baktériumokat bakteriofágok segítségével azonosítanak (Milch és Pászti 2008). A módszer azon alapszik, hogy a vizsgálatban használt úgynevezett típusfágok az azonosítandó baktériumtörzseket azok fogékonysága esetén lizálják (Haq és mtsai. 2012).

A fágok, gazdaspecifitásukat adó receptor kötő fehérjéken alapuló molekuláris próbák révén, kórokozó baktériumok gyors kimutatására (Singh és mtsai. 2012) is használhatók, továbbá potenciálisan terapeuta gének (Barry és mtsai. 1996) és vaccinák antigénjeinek (Clark 
és March 2004) szállítására, valamint hidrológiai modellezésekben jelölőanyagnak (Martin 1988) is alkalmasak.

Szerepük lehet a biztonságos élelmiszergyártás folyamataiban (Goodridge és Bisha 2011), de kórházi felületek fertőtlenítésére (Brusina és mtsai. 2013) is eredményesen használhatók.

\subsection{FÁGTERÁPIA A NÖVÉNYVÉDELEMBEN}

Bár már az 1920-as években felmerült az az ötlet, hogy bakteriofágokat használjanak fel növényi kórokozó baktériumok ellen (Mallmann és Hemstreet 1924), az antibiotikumok felfedezése visszavetette a bakteriális betegségek fágokkal való kezelésére irányuló, Nyugaton folyó kutatásokat (Summers 2001). A fágok sikeres orvosi alkalmazása terén bővülő ismeretek, a réz- és antibiotikum-rezisztens növénykórokozó baktériumtörzsek megjelenése, valamint a környezetbarát növényvédő szerek iránti igény azonban ismét felkeltette az érdeklődést a bakteriofág-alapú növényvédelmi módszerek kidolgozására. Az első fág-tartalmú módszert 1983-ban szabadalmaztatták az Amerikai Egyesült Államokban, amelyet a fagykárt előidéző jégmag-képző baktériumok [(pl. Erwinia herbicola (syn. Pantoea agglomerans), Pseudomonas syringae) ellen dolgoztak ki (Kozloff és Schnell 1983). A fágok növényvédelmi alkalmazására $\begin{array}{lllll}\text { vonatkozó máig } & \text { legismertebb ászítmény } & \text { AgriPhage } & \end{array}$ http://omnilytics.com/products/agriphage), amely a paprika és a paradicsom pszeudomónászos és xantomónászos betegsége ellen hatékony; a Pseudomonas syringae pv. tomato és Xanthomonas campestris pv. vesicatoria vad típusú és ún. gazdakör-mutáns („host range mutant”) (Jackson 1989, Flaherty és mtsai. 2000) fágjainak a kombinációját tartalmazza. Az első E. amylovora elleni bakteriofág-alapú biopeszticid, mely a PhiEaH1 (GenBank-i leltári szám: KF623294) és PhiEaH2 (JX316028.1) fágtörzseket valamint UV elleni védőanyagot tartalmaz, Erwiphage néven 2012-től szükséghelyzeti engedéllyel alkalmazható Magyarországon (Meczker és mtsai. 2014). A növényvédelmi célú fágterápiás kutatások eddigi eredményeit több cikk is feldolgozta (Balogh és mtsai. 2010, Frampton és mtsai. 2012, Jones és mtsai. 2007, Nagy és mtsai. 2012, Svircev és mtsai. 2010).

A bakteriofágokat érintő kutatások hazánkban nagy múltra tekintenek vissza (Klement 1959, Klement és Király 1957, Klement és Lovas 1957, 1959, 1960). A bakteriofágok már hatékonynak bizonyultak számos patogén baktérium okozta növényi betegség ellen (Balogh és mtsai. 2010). Így az Erwinia spp. által okozott kála baktériumos lágyrothadása (Ravensdale és mtsai. 2007), az almatermésüek tüzelhalása (Kovács és mtsai. 2012, Meczker és mtsai. 2014, Lehman 2007, Schnabel és mtsai. 1999, Schwarczinger és mtsai. 2011, Svircev és mtsai. 2006); a Xanthomonas spp. által okozott paradicsom xantomónászos betegsége (Balogh és 
mtsai. 2003, Flaherty és mtsai. 2000, Iriarte és mtsai. 2012); az őszibarack (Civerolo és Kiel 1969, Saccardi és mtsai. 1993), a muskátli (Flaherty és mtsai. 2001), a citrusfélék (Balogh és mtsai. 2008), a dió (McNeil és mtsai. 2001) bakteriózisa; a hagyma xantomónászos betegsége (Lang és mtsai. 2007), a káposzta feketeerüsége (Marroni és Germani 2014); citrusfélék xantomónászos betegségei (Balogh és mtsai. 2008); a Ralstonia solanacearum által okozott dohány baktériumos hervadása (Iriarte és mtsai. 2012, Tanaka és mtsai. 1990); termesztett gombában a Pseudomonas spp. által okozott baktériumos foltosodás (Munsch és Olivier 1995); a Streptomyces scabies által okozott burgonya varasodása (McKenna és mtsai. 2001) és a szőlő agrobaktériumos gyökérgolyvája (Boyd és mtsai. 1971) ellen.

\subsection{FÁGOK ALKALMAZÁSA AZ ERWINIA AMYLOVORA ELLEN 3.6.1 FÁGIZOLÁLÁS}

A növénykórokozó baktériumok elleni bakteriofágokkal való védekezés elsődleges lépése az adott kórokozóra specifikus fágok izolálása. Ez az E. amylovora esetében mind a tủzelhalás tünetét mutató, vagy ritkábban tünetmentes növényi részről, mind a növény közvetlen környezetében lévő talajból történhet, mely utóbbi feltételezett fágrezervoárként szolgál (Crosse és Hingorani 1958). Noha korábban többen beszámoltak E. amylovora-t lizálni képes bakteriofág izolátumokról (Billing 1960, Okabe és Goto 1963), elsőként Erskine (1973) tett átfogó javaslatot a tủzelhalás elleni bakteriofág alapú biológiai védekezés alkalmazására, aki talajmintából izolált E. amylovora-specifikus fággal végzett kísérleteket. A folyamat, melyben egy (Ritchie és Klos 1977), illetőleg több (Gill és mtsai. 2003) gazdabaktérium törzzsel történik a fágizolálás gazdaspecifikus, illetve szélesebb gazdakörü fág izolálásához vezet.

\subsubsection{FÁGIZOLÁTUMOK JELLEMZÉSE}

A korai vizsgálatokat (Erskine 1973, Ritchi és Klos 1979) követően mára egyre több kutatás tárta fel a különböző E. amylovora fágizolátumok sajátosságait, vizsgálva többek között gazdakörüket, partikulum-, illetve plakkmorfológiájukat, molekuláris felépítésüket PCR, RFLP (restrikciós fragmentum hossz polimorfizmus) technikával és szekvencia analízissel (Born és mtsai. 2011, Boulé és mtsai. 2011, Dömötör és mtsai. 2012, Gill és mtsai. 2003, Lehman és mtsai. 2009, Meczker és mtsai. 2014, Müller és mtsai. 2011a, 2011b, Schnabel és Jones 2001). Mára 11 E. amylovora-specifikus bakteriofág [Era103 (GenBank-i leltári szám: EF160123.1); ФEa21-4 (Lehman és mtsai. 2009); ФEa1h, ФEa100, ФEa104 (Müller és mtsai. 2011b); vB_EamP-L1, vB_EamM-M7, vB_EamP-S6, és vB_EamM-Y2 (Born és mtsai. 2011.), phiEaH2 (Dömötör és mtsai. 2012), phiEaH1 (Meczker és mtsai. 2014)] teljes genomja ismert. 


\subsubsection{FÁGOK HATÉKONYSÁGI VIZSGÁLATAI}

A fágizolátumok gazdabaktériumra gyakorolt hatását folyadékkultúrában, körte- (Boulé és mtsai. 2011, Lehman 2007), illetve almavirágokon (Schwarczinger és mtsai. 2011, Müller és mtsai. 2011a) éretlen zöld körtegyümölcs szeleteken (Müller és mtsai. 2011a) vizsgálják in vitro. Ezek közül a virágokon végzett tesztelésekkel lehet a potenciálisan leghatékonyabb fágizolátumokat kiválasztani, mivel a kórokozó elleni biológiai védekezés fő stratégiája az $E$. amylovora populáció bibéken történő tavaszi felszaporodásának (Thomson 1986), ezáltal az elsődleges virágfertőzésnek a megakadályozása. Azokban az országokban, ahol tiltó rendelkezések miatt a természetben mesterséges inokuláció nem végezhető, a szabadföldi kísérletekben (Kovács és mtsai. 2012) csak a természetes E. amylovora fertőzésekkel lehet „dolgozni”.

\subsubsection{KIHÍVÁSOK ÉS TÁVLATOK A FÁGTERÁPIA TERÉN}

A növénypatogén baktériumokat fertőző fágok, köztük az E. amylovora-specifikus fágok életmódjáról, ökológiai igényeiről, és genetikai felépítéséről napjainkra jelentős mennyiségü információ halmozódott fel (Ackermann és DuBow 1987, Adams 1959, Civerolo 1972, Gill és Abedon 2003, Gill és mtsai. 2003, Lehman és mtsai. 2009, Müller és mtsai. 2011a, 2011b, Schnabel és Jones 2001). Ezek alapján fény derült arra, hogy e fágok számos olyan tulajdonsággal rendelkeznek, amely lehetővé teszi a növényvédelemben való eredményes felhasználásukat: nagy számban fordulnak elő a természetben, veszélytelenek az eukarióta szervezetekre, meghatározott baktériumfajokra, illetve törzsekre specifikusak és ezáltal a honos, nem patogén baktérium flórát nem károsítják, továbbá a fág izolálás, felszaporítás, és tárolás viszonylag egyszerü és nem költséges folyamat (Jones és mtsai. 2007, Nagy és mtsai. 2012). Noha a fágoknak szembe kell nézniük bakteriális védekező mechanizmusokkal (Hyman és Abedon 2010) és ismeretes, hogy fennáll a lehetősége fág-rezisztens baktérium törzsek kialakulásának (Okabe és Goto 1963, Roach és mtsai. 2008), ezek a hátrányok lítikus és gazdakör-mutáns fágok és fágkombinációk alkalmazásával kezelhetők (Schnabel és mtsai. 1999, Svircev és mtsai. 2010).

A változó környezeti körülményekre való nagyfokú érzékenységük, miszerint szélsőséges hőmérséklet, $\mathrm{pH}$, és csapadék viszonyok, valamint erös UV sugárzás mellett könnyen inaktiválódhatnak (Iriarte és mtsai. 2007), igazi kihívást jelent biopeszticidként való felhasználásuk során. A fágok növényi zöldfelületen való fennmaradását és ezáltal hatékonyságukat nagyban elősegíti az, ha megfelelő időben (Balogh és mtsai. 2007), koncentrációban, és védőanyagokkal (Balogh és mtsai. 2003), vagy bizonyos antagonista 
szaprofiton baktériumokkal együtt (Boulé és mtsai. 2011, Lehman 2007, Svircev és mtsai. 2006) történik a védendő növény felületére való kijuttatásuk.

A fágok életképességének fokozását célzó másik lehetséges irány a fágok védendő növénybe történő juttatása. A rizoszféra (a talajnak a gyökeret körülvevő zónája, amelyben közvetlen kapcsolat alakul ki a növény és a talaj mikroorganizmusai között) kedvezőbb környezetet biztosíthat a fágok számára (Jones és mtsai. 2007) figyelembe véve, hogy a talaj szerkezetétől, állapotától függően (például alacsony $\mathrm{pH}$ ) a fágok talajszemcsékhez történő adszorpciója lecsökkenti a szabad, fertőzőképes fágok számát (Assadian és mtsai. 2005, Sykes és mtsai. 1981). A vírusok azon képessége, hogy a gyökéren keresztül a növénybe tudnak jutni régtől ismert (Mazur és Paciorkiewicz 1973, Murphy és Syverton 1958, Helms és Wardlaw 1976, Oron és mtsai. 1995). Számos tudományos munka számolt be arról, hogy a bakteriofágok is képesek a gyökéren keresztüli penetrációra és azt követően a növény távolabbi részeibe történő transzlokációra (Rao és Srivastava 1973, Ward és Mahler 1982) életképességüket napokig megőrizve (Boyd és mtsai. 1971, Iriarte és mtsai. 2012). Az is igazolást nyert, hogy adott növénypatogén baktériumokra specifikus fágok talajra irányuló kijuttatását követően a baktériumkórokozó által kiváltott betegség mértéke lecsökkent (Boyd és mtsai. 1971, Fujiwara és mtsai. 2011, Iriarte és mtsai. 2012). A fágoknak a növény földfelszíni részein keresztül való penetrációs képességéről azonban kevés információ áll rendelkezésre (Kovács és mtsai. 2012, 2013) és az E. amylovora fágjaival kapcsolatban ez a fajta fág-növény interakció eddig még nem került jellemzésre. 


\section{ANYAG ÉS MÓDSZER}

\subsection{A VIZSGÁLATOK HELYE ÉS IDEJE}

A bakteriofágok gyüjtése Magyarország különböző földrajzi területeiröl, ültetvényeken, közterületen, illetve kertekben fellelt gazdanövények tüzelhalás tüneteit mutató növényi részeiről az adott év (2006, 2007) áprilisától késő augusztusig terjedő időszaka alatt történt.

A bakteriofágok izolálása és tisztítása, plakkmorfológiai, molekuláris, gazdakör, valamint az E. amylovora okozta tünetekre gyakorolt hatásuk különböző in vitro vizsgálatai a fágtranszlokációs tesztekkel együtt az MTA ATK Növényvédelmi Intézet, Biotechnológiai osztályának akkreditált Erwinia-laboratóriumaiban történtek 2006-2013 között.

A fágpartikulumok transzmissziós elektronmikroszkóppal végzett morfológiai jellemzése az MTA Természettudományi Kutatóközpont Anyag- és Környezetkémiai Intézetében, Szabó László vezetésével történt.

Az általunk tervezett primerek előállítását az Invitrogen, Life Technologies (Budapest, Magyarország) és a Microsynth (Balgach, Svájc) laboratóriumaiban végezték.

Egyes fágizolátumaink adott géneket kódoló szakaszai bázissorrendjét az Eurofins MWG Operon (Ebersberg, Németország) laboratóriumában határozták meg 2008 és 2013-ban.

\subsection{A VIZSGÁLATOK SORÁN HASZNÁLT BAKTÉRIUM-IZOLÁTU- MOK, ILLETVE TÖRZSEK}

A vizsgálatokban szereplő, Süle Sándor, Hevesi Mária, Klaus Geider és Bozsó Zoltán által a rendelkezésünkre bocsátott baktérium-izolátumokat, illetve törzseket az 1.a-b táblázat foglalja magába.

1.a táblázat A vizsgálatainkban szereplő tesztbaktériumok: magyarországi E. amylovora izolátumok (Ea1-Ea31), egyéb E. amylovora törzsek, és más Erwinia fajok

Baktérium-izolátum / törzs $\quad$ Forrás / Hivatkozás ${ }^{b}$

Ea1

Hevesi M. / Hevesi (1996)

Ea2, Ea3, Ea4, Ea5, Ea6, Ea7, Ea8, Ea10, Ea11, Ea12, Németh J. és Süle S. / (nk)

Ea13, Ea14, Ea15, Ea17, Ea18, Ea19, Ea20, Ea21, Ea22,

$\mathrm{Ea} 24, \mathrm{Ea} 25, \mathrm{Ea} 26, \mathrm{Ea} 27, \mathrm{Ea} 28, \mathrm{Ea} 30, \mathrm{Ea} 31$

$\mathrm{Ea} 1 / 79$

Falkenstein és mtsai. (1988)

Ea1/79del100

K. Geider / Bugert és Geider (1995) 


\begin{tabular}{ll}
\hline Baktérium-izolátum / törzs & Forrás / Hivatkozás $^{\mathbf{b}}$ \\
\hline Ea1/79Sm & K. Geider / Bellemann és mtsai. (1994) \\
EaDS02 & K. Geider \\
EaDS05 & K. Geider \\
EaRW1/06 & K. Geider \\
EaOR1/07 & K. Geider \\
Ea63/05 & K. Geider \\
EaCFBP1430 & K. Geider, CFBP \\
E. billingiae Eb661 & K. Geider / Mergaert és mtsai. (1999) \\
E. persicina & K. Geider / Hao és mtsai. (1990) \\
E. rhapontici CFBP $3618 T$ & K. Geider / Hauben és mtsai. (1998) \\
E. tasmaniensis Et1/99 & K. Geider /Kube és mtsai. (2010) \\
\hline
\end{tabular}

${ }^{\mathrm{b}}$ nk: nem közölt; CFBP: Collection Francaise de Bactéries Phytopathogenes

1.b táblázat A vizsgálatainkban szereplő tesztbaktériumok: Pantoea agglomerans izolátumok és törzsek, Pantoea fajok, valamint egyéb baktériumfajok, illetve törzsek

\begin{tabular}{ll}
\hline Baktérium fajok / izolátumok, törzsek & Forrás / Hivatkozás \\
\hline Pantoea agglomerans NB2 & Süle S. \\
Pantoea agglomerans MB96 & Süle S. \\
Pantoea agglomerans JCM 1236 & BCE, NMGY, B02248 / Gavini és mtsai. (1989) \\
Pantoea agglomerans hu82245 & Süle S. \\
Pantoea agglomerans hu82647 & Süle S. \\
Pantoea agglomerans C9-1 & Süle S. \\
Pantoea citrea CCM 4319 & BCE, NMGY, B02244 / Kageyama és mtsai. (1992) \\
Pantoea stewartii subsp. stewarti DC283 & BCE, NMGY / Coplin és mtsai. (2002) \\
Pantoea stewartii subsp. stewartii SW2 & Süle S. / Coplin és mtsai. (1981) \\
Agrobacterium tumefaciens C58 & Süle S. / Hamilton és Fall (1971) \\
Agrobacterium vitis F2/5 & Süle S. / Staphorst és mtsai. (1985) \\
Escherichia coli DH5 $\alpha$ & Bozsó Z. / Hanahan (1985) \\
Xanthomonas campestris pv. zinniae & Schwarczinger I. / Schwarczinger és mtsai. (2008) \\
Pseudomonas cichorii & Süle S. / Kersters és mtsai. (1996) \\
Pseudomonas syringae pv. syringae H9 & Süle S. / Seemüller és Arnold (1978) \\
\hline
\end{tabular}




\begin{tabular}{ll}
\hline Baktérium fajok / izolátumok, törzsek & Forrás / Hivatkozás $^{\text {a }}$ \\
\hline $\begin{array}{l}\text { Pectobacterium carotovorum subsp. } \\
\text { carotovorum } 19111\end{array}$ & Németh J. / Hauben és mtsai. (1998) \\
$\begin{array}{l}\text { Pectobacterium carotovorum subsp. } \\
\text { atroseptica D2 }\end{array}$ & Németh J./ Hauben és mtsai. (1998) \\
\hline${ }^{\mathrm{a}}$ BCE NMGY: Budapesti Corvinus Egyetem Nemzeti Mikrobiológiai Gyüjtemény
\end{tabular}

\section{Tesztbaktériumok profágtartalmának ellenőrzése}

A baktérium-izolátumok és törzsek közül az Ea18, az Ea1/79, az Ea1/79Sm és az EaCFBP1430 profág (a baktérium örökítő anyagába integrálódott fággenom) tartalma előzetesen mitomycines kezeléssel (Hevesi M. személyes közlés) lett ellenőrizve a következők szerint: 100 $\mu \mathrm{l}$ egyéjszakás tesztbaktérium kultúrát $10 \mathrm{ml}$ LB-hez adtunk, amit $10 \mu \mathrm{l}\left(2 \mathrm{mg} \mathrm{ml}^{-1}\right)$ mitomicinC-vel egészítettünk ki. Három órán át rázattuk, majd ismét $10 \mathrm{ml}$ LB-t adtunk hozzá. Ezt ismét rázatás követte. Az így nyert baktériumkultúrából 24 és 48 óra elteltével 1-1 ml mintát vettünk, amit kloroformoztunk (a baktériumsejtek 2\% kloroform hozzáadásával, 10 perc inkubációs időszak alatt elölésre kerültek) és centrifugáltunk (13500 rpm, 10 perc, $\left.4^{\circ} \mathrm{C}\right)$, majd a felülúszóból $10 \mu l$-t cseppentettük fel az indikátor baktériummezőre és megfigyeltük, hogy 24, illetve 48 óra elteltével alakulnak-e ki plakkok.

\subsection{REFERENCIA BAKTERIOFÁGOK}

A hazai fágizolátumaink plakkmorfológiai és molekuláris összehasonlító vizsgálataihoz referenciaként Alan L. Jones (Michigan State University, USA) által, az Amerikai Egyesült Államokban izolált fág törzseket használtunk, amelyeket Klaus Geider (Julius Kühn-Institut, Institute for Plant Protection in Fruit Crops and Viticulture, Dossenheim, Németország) bocsátott rendelkezésünkre (2. táblázat).

2. táblázat Az összehasonlító vizsgálatoknál referenciaként használt amerikai (Michigan, USA) E. amylovora fágok származási adatai

\begin{tabular}{llc}
\hline Fágtörzs & \multicolumn{1}{c}{ Eredete } & \multicolumn{1}{c}{ Hivatkozás } \\
\hline ФEa1h & $\begin{array}{l}\text { tüzelhalásos almahajtás (Malus x domestica } \\
\text { 'Jonathan'), 1975 }\end{array}$ & Ritchie és Klos (1975) \\
\hline ФEa100 & talajminta, 1996 & Schnabel és Jones (2001) \\
ФEa104 & talajminta almaültetvényböl, 1996 & \\
ФEa116 & tüzelhalás tünetét mutató alma-szövet, 1996 & \\
\hline
\end{tabular}




\subsection{TÁPTALAJOK, TÁPOLDATOK}

\section{Tesztbaktériumok számára}

Az Erwinia és a Pantoea nemzetségbe tartozó fajok többsége LB (Luria-Bertani) tápoldatban, illetve agar tartalmú szilárd LBA táptalajon (az E. amylovora Ea1/79Sm törzs szelektív, 300 vagy 500 ppm sztreptomicin-szulfáttal (Duchefa Biochemie) kiegészített LBA-n), $28^{\circ} \mathrm{C}$-on volt tenyésztve. Kivételt képeztek a $P$. agglomerans MB96 és a $P$. stewartii subsp. stewartii törzsek, amelyek CPG (Casamino-acid Peptone Glucose) tápoldatban voltak tenyésztve. Az Agrobacterium törzsek tenyésztése NB (Nutrient Broth)-ben $28^{\circ} \mathrm{C}$-on, az Escherichia coli törzsé LB-ben $37^{\circ} \mathrm{C}$-on, a Xanthomonas campestris pv. zinniae NB, illetve NA (Nutrient Agar)ban, míg a Pseudomonas fajok és a Pectobacterium törzsek tenyésztése NA táptalajon történt. Az egyes tápoldatok, táptalajok összetételét illetően Schaad és mtsai. (2001) szerint jártunk el.

A fág hatásvizsgálatok során tesztbaktériumként alkalmazott E. amylovora törzseket sztreptomicin (300 ppm) tartalmú szelektív (Ea1/79Sm), illetve antibiotikum-mentes (Ea1/79) LBA táptalajon, rendszeresen átoltva $4^{\circ} \mathrm{C}$-on tároltuk, majd a kísérletekhez a sztreptomicinnel kiegészített (500 ppm), vagy antibiotikum-mentes LB tápoldatban egy éjszakán át folyamatosan rázatva szaporítottuk fel.

Az egyes baktérium-izolátumok és törzsek megőrzése $-70^{\circ} \mathrm{C}$-on fagyasztó csőben, az adott baktérium számára optimális tápoldatban történt, amit 30\% glicerinnel egészítettünk ki.

\section{Bakteriofágok részére}

A bakteriofágok izolálásához, felszaporításához zselatint tartalmazó SM puffert használtunk, melynek összetétele a következö: $100 \mathrm{mmol}^{-1} \mathrm{NaCl}, 8 \mathrm{mmol} \mathrm{l}^{-1} \mathrm{MgSO}_{4} \cdot 7 \mathrm{H}_{2} \mathrm{O}, 50$ mmol l${ }^{-1}$ Tris-Cl (1 mol ${ }^{-1}$, pH 7,5), 0,002\% (w/v) zselatin.

A fágok tárolása sötétben $4{ }^{\circ} \mathrm{C}$-on $2 \%$ végtérfogatú kloroformmal $\left(\mathrm{CHCl}_{3}\right)$, illetve $-70^{\circ} \mathrm{C}$-on fagyasztó csőben, $15 \%$ glicerint tartalmazó LB-ben történt.

\subsection{A VIZSGÁLT FÁGOK IZOLÁLÁSA ÉS TISZTÍTÁSA}

\section{A vizsgálat anyaga}

Tủzelhalás tünetét mutató alma (Malus x domestica Borkh.), körte (Pyrus communis L.), birs (Cydonia oblonga Mill.) különböző növényi részeiből (ág, levél, virág, termés) történt az izolálás. 
Három hazai baktérium-izolátumot (Ea12, Ea18, Ea26) alkalmaztunk a fágizolálás, illetve a fágdetektálás során. Az izoláláshoz az izolátumok keverékét, a fágdetektáláshoz az izolátumokat külön-külön használtuk.

\section{A vizsgálat módszere}

\section{Izolálás}

Az izolálást Crosse és Hingorani (1958) módosított módszerével végeztük. Tủzelhalás tünetét mutató növényi mintából 20-60 grammnyit 60 ml LB tápoldatba tettünk, amit az egyes $E$. amylovora izolátumok egyéjszakás rázatott kultúrájából, izolátumonként $200 \mu$ l-rel egészítettünk ki, majd rázattunk $28^{\circ} \mathrm{C}$-on, 48 órán át. Az így felszaporított fágokat tartalmazó oldatban a baktériumsejtek 2\% kloroform hozzáadásával, 10 perc inkubációs időszak alatt elölésre kerültek. Ezt követően a baktériumok $4^{\circ} \mathrm{C}$-on, 13500 rpm-en, 20 percig tartó centrifugálással lettek leülepítve.

\section{A fágok kimutatása}

\section{Módosított cseppteszt (Adams 1959)}

A mintegy $45^{\circ} \mathrm{C}$-ra kihült, $2 \mathrm{ml}, 0,7 \%$ agart tartalmazó, úgynevezett LB fedőagarhoz 100 $\mu \mathrm{l}, 10^{8} \mathrm{CFU} \mathrm{ml}^{-1}$ egyéjszakás baktériumkultúrát adtunk, amit az előzetesen Petri csészébe kiöntött és megszilárdult LBA táptalaj felszínére öntöttünk. Az izolálási folyamat végén nyert felülúszóból százszoros hígítási sort készítettünk. Ezekből 10-10 $\mu$ l-t pipettáztuk a fedőagar réteg megdermedését követően a táptalaj felszínére, majd $28^{\circ} \mathrm{C}$-on, egy napig sötétben, termosztátban inkubáltuk a mintákat.

\section{Adams-féle dupla agar réteg (Adams 1959) módosított módszerével történö szélesztés}

Azokat a hígításokat, amelyek a lágyagar rétegen a felcseppentés helyén különálló, szabad szemmel könnyen számolható tiszta foltot (plakkot) adtak, szélesztettük: a fent leírt, tesztbaktériumot $(100 \mu \mathrm{l})$ tartalmazó fedőagarhoz hozzáadtuk az adott hígítású fágszuszpenziót (100 $\mu \mathrm{l})$, és azt, alaposan összekeverve öntöttük a szilárd LBA táptalajra. A megszilárdult lemezeket $28^{\circ} \mathrm{C}$-on, egy napig sötétben, termosztátban inkubáltuk. 


\section{Fáglizátumok tisztítása}

Az egy napos inkubációt követően a lágyagar rétegen kialakuló különálló tiszta foltok, azaz plakkok képezték az egyes izolátumok kiinduló forrásait. Ezt követően egy-egy mintából több különböző plakkmorfológiájú, tehát eltérő alakú, nagyságú, tisztaságú plakkokat szúrtunk ki steril pipettaheggyel. Az így kiszúrt plakkokat zselatint tartalmazó SM pufferbe pipettáztuk, majd 2\% kloroform hozzáadásával $13500 \mathrm{rpm}$-en, 10 percig, $4^{\circ} \mathrm{C}$-on centrifugáltuk. A felülúszót a fent leírtak alapján ismét szélesztettük. Ezt a procedúrát mindaddig ismételtük míg a szélesztéskor egyöntetủ morfológiájú plakkokat nem kaptunk egy-egy lemezen.

\subsection{A FÁGIZOLÁTUMOK MORFOLÓGIAI JELLEMZÉSE}

\subsubsection{PLAKKMORFOLÓGIA}

\section{A vizsgálat anyaga}

Huszonkettő megtisztított bakteriofág izolátumunk (H1A, H1B, H2A, H2B, H4A, H4B, H5A, H5K, H5B, H6A, H6B, H7A, H7B, H8A, H8B, H9A, H9B, H10A, H10B, H11, H12A, H12B) és 4 amerikai fágtörzs (2. táblázat) jellemzéséhez tesztbaktériumként az EaCFBP1430 számú francia E. amylovora törzset használtuk.

\section{A vizsgálat módszere}

A fágok jellemzésének és elkülönítésének első lépése a tesztbaktériumot tartalmazó fedőrétegen kialakult plakkok méretének és a plakk körül képzett körkörös sáv szélességének vizsgálata, melyhez a megtisztított bakteriofág izolátumokat a módosított Adams-féle dupla agar réteg módszerrel (lásd 4.5 fejezet), a tesztbaktériumot tartalmazó, 1\% szacharózzal kiegészített, LBA fedő lemezre szélesztettük.

A 24 órás inkubációt követően kialakult plakkok méretének és a plakkokat körülvevő sáv szélességének meghatározása 50 plakk mm-ben mért értékeinek átlagában történt. 


\subsubsection{FÁGPARTIKULUM MORFOLÓGIA}

\section{A vizsgálat anyaga}

Munkánk során tizenkilenc fágizolátum (H1A, H1B, H2A, H2B, H4A, H4B, H5A, H5B, H6A, H7A, H7B, H8A, H8B, H9A, H9B, H10A, H10B, H11, H12B) vizsgálatát végeztük el, izolátumonként legkevesebb 50 fágot mérve.

\section{A vizsgálat módszere}

A fágok rendszertani besorolásának egyik alapja a vírus partikulumok morfológiai jellemzése, vagyis a fágok feji és farki része alakjának és méretének elektronmikroszkóppal történő vizsgálata. A vizsgálatot megelőzően a friss fáglizátum $2 \%$ kloroform hozzáadásával és 13500 rpm-en, $4^{\circ} \mathrm{C}$-on, 20 percig tartó centrifugálással került bakériummentesítésre, majd 15300 rpm-en 3 órán át $4^{\circ} \mathrm{C}$-on újra le lett centrifugálva. A fágokat tartalmazó üledék 50-100 $\mu$ l steril desztillált vízben lett felvéve. Az így előkészített mintákat negatív festési eljárással, Gill és mtsai. (2003) módszere alapján, Morgagni 268D típusú transzmissziós elektronmikroszkóppal (TEM) vizsgáltuk.

\subsection{PCR VIZSGÁLAT}

PCR vizsgálattal mutattuk ki különbözö DNS szakaszok meglétét, illetve hiányát az adott hazai fágizolátumokban.

\section{A vizsgálat anyaga}

\section{Fágizolátumok és törzsek}

Huszonegy fágizolátumunkat (H1A, H1B, H2A, H2B, H4A, H4B, H5A, H5K, H5B, H6B, H7A, H7B, H8A, H8B, H9A, H9B, H10A, H10B, H11, H12A, H12B) és a négy amerikai fágtörzset (2. táblázat) vizsgáltuk.

\section{Primerek}

Ehhez 13, a vizsgált DNS szakaszokra specifikus indító szekvenciát, azaz primer párt használtunk (3. táblázat). Az EPS depolimeráz, a holin, a lizozim, a termináz, a peptidáz és a Mu-szerü profág proteinekre specifikus primer párokat K. Geider, a PEa1A/B indító szekvenciákat Gill és mtsai. (2003), a többi primert Kolozsváriné N.J. és Schwarczinger I. tervezte. 
3. táblázat A magyar fágizolátumok PCR vizsgálatai során használt indító szekvenciák paraméterei

\begin{tabular}{|c|c|c|c|c|}
\hline $\begin{array}{c}\text { Vizsgált } \\
\text { DNS } \\
\text { szakasz }\end{array}$ & $\begin{array}{l}\text { Indító szekvencia } \\
\text { jelölése }\end{array}$ & $\begin{array}{l}\text { Indító szekvencia nukleotid sorrendje } \\
\qquad\left(5^{\prime}-3^{\prime}\right)\end{array}$ & $\begin{array}{c}\text { Várható } \\
\text { termék } \\
\text { hossza } \\
\text { (bp) }\end{array}$ & PCR \\
\hline \multirow{2}{*}{$\begin{array}{l}\text { EPS } \\
\text { depoli- } \\
\text { meráz }\end{array}$} & Dpo-1 (forward) & GGACATACCGTGGGAAGTG & \multirow[t]{2}{*}{1006} & \multirow{12}{*}{$\begin{array}{c}\mathrm{MM} 2 \\
\mathrm{~A}_{\mathrm{t}}=47^{\circ} \mathrm{C}\end{array}$} \\
\hline & Dpo-2c (reverse) & ATTGAGCCGGAGTTGATG & & \\
\hline \multirow[t]{2}{*}{ holin } & Hol-F & GCTAACGGTGTCGTCTCATA & \multirow[t]{2}{*}{361} & \\
\hline & Hol-R & CAGTTGCCGCGTTCTTGTTT & & \\
\hline \multirow[t]{2}{*}{ lizozim } & Lys-F & GCTGGACTTCTGGTAGACTT & \multirow[t]{2}{*}{537} & \\
\hline & Lys-R & GCTTGCTGGTAACTCCTGTA & & \\
\hline \multirow[t]{2}{*}{ termináz } & Term-F & GAAGCTGTGTAAGCCTCTGT & \multirow[t]{2}{*}{1079} & \\
\hline & Term-R & GTGAGGCTGGTTCGTCAACT & & \\
\hline \multirow[t]{2}{*}{ peptidáz } & Pep-F & CAACTGTCCAAGACGGTGTA & \multirow[t]{2}{*}{551} & \\
\hline & Pep-R & CAGAGATACCGCGAGAACTT & & \\
\hline \multirow{2}{*}{$\begin{array}{c}\text { Mu-szerü } \\
\text { profág } \\
\text { protein }\end{array}$} & $\mathrm{Mu}-\mathrm{F}$ & CCGAGGTAGTGAATGGCTAA & \multirow[t]{2}{*}{614} & \\
\hline & $\mathrm{Mu}-\mathrm{R}$ & CTCTGTCCAGAAGCCATGT & & \\
\hline \multirow[t]{2}{*}{$\Phi$ Ealh } & PEa1A (forward) & AATGGGCACCGTAAGCAGT & \multirow[t]{2}{*}{304} & \multirow{6}{*}{$\begin{array}{c}\mathrm{MM} 3 \\
\mathrm{~A}_{\mathrm{t}}=60^{\circ} \mathrm{C}\end{array}$} \\
\hline & PEa1B (reverse) & TAATGGGTATGATAGAAGGCAGA & & \\
\hline \multirow[t]{2}{*}{$\Phi \mathrm{Ea} 100$} & Ea100F & ACTTGCGTGAGTGGTGCAA & \multirow[t]{2}{*}{344} & \\
\hline & Ea100R & GCAGACTAGCCACCTTCGAC & & \\
\hline \multirow[t]{2}{*}{ ФEa104 } & Ea104F & GGCTGCTGGCGCTCCTTACC & \multirow[t]{2}{*}{665} & \\
\hline & Ea104R & ATCAGGCCGTGCGCCAAGTC & & \\
\hline \multirow{2}{*}{$\begin{array}{l}\text { ФEalh } \\
\text { kapszid }\end{array}$} & 1hcapF & GGTAGGCACCAATAGC & \multirow[t]{2}{*}{474} & \multirow{4}{*}{$\begin{array}{c}\mathrm{MM} 3 \\
\mathrm{~A}_{\mathrm{t}}=56^{\circ} \mathrm{C}\end{array}$} \\
\hline & 1hcapR & CAGTTGAACGCAGTCC & & \\
\hline \multirow{2}{*}{$\begin{array}{l}\Phi E a H 2 \\
\text { kapszid }\end{array}$} & $\mathrm{H} 2 \mathrm{capF}$ & GTATTCTGAACGCGCTGCTG & \multirow[t]{2}{*}{508} & \\
\hline & H2capR & CAGTCCAGAGACTTGGCGTT & & \\
\hline \multirow{2}{*}{$\begin{array}{c}\text { Ea7/74 } \\
\text { amsF gén }\end{array}$} & $\mathrm{EaFF}$ & CAGAAGATGACGGCGGCTAT & \multirow[t]{2}{*}{677} & \multirow{2}{*}{$\begin{array}{c}\mathrm{MM} 3 \\
\mathrm{~A}_{\mathrm{t}}=57^{\circ} \mathrm{C}\end{array}$} \\
\hline & EaFR & GCAGCGCGGTAAATTAAGCA & & \\
\hline
\end{tabular}




\begin{tabular}{|c|c|c|c|c|}
\hline $\begin{array}{c}\text { Vizsgált } \\
\text { DNS } \\
\text { szakasz }\end{array}$ & $\begin{array}{c}\text { Indító szekvencia } \\
\text { jelölése }\end{array}$ & $\begin{array}{c}\text { Indító szekvencia nukleotid sorrendje } \\
\left(\mathbf{5}^{\prime}-\mathbf{3}^{\prime}\right)\end{array}$ & $\begin{array}{c}\text { Várható } \\
\text { termék } \\
\text { hossza } \\
\text { (bp) }\end{array}$ & PCR \\
\hline $\begin{array}{c}\text { ФEaH2 } \\
\begin{array}{c}\text { amsF gén- } \\
\text { szerú } \\
\text { régió }\end{array}\end{array}$ & phiEaH2-F & AGCTGTCAAACTTCAACGTGC & 609 & $\begin{array}{c}\text { MM3 } \\
\mathrm{A}_{\mathrm{t}}=57^{\circ} \mathrm{C}\end{array}$ \\
\cline { 2 - 5 } & phiEaH2-R & TGACGTTCTTCACCGGACAG & \\
\hline
\end{tabular}

Az indítószekvenciák jelölésénél a név végén szereplö $\mathrm{F}$, illetve $\mathrm{R}$ betü a primer irányultságára utal: $\mathrm{F}=$ forward, $\mathrm{R}=$ reverse; $\mathrm{A}_{\mathrm{t}}=\mathrm{az}$ anellálás hőmérséklete; MM2, illetve MM3 az adott PCR program jelölése.

A 3. táblázatban szereplő első három primer pár az amerikai $\Phi E a 1 h$ fágban jelenlévő génekre specifikus, amelyek három enzimet, az extracelluláris poliszacharid (EPS) depolimerázt, a holint, illetve a lizozimet kódolják. Az EPS depolimeráz (dpo) gén egy olyan depolimeráz típusú köpenyfehérjét kódol, amely hozzákötődik a baktérium EPS burkához, majd addig bontja a polimert, míg a sejt felszíne szabaddá válik. Ez által lehetővé teszi, hogy a fág a baktériumsejt egy külső membrán receptorához kötődhessen és azt követően nukleinsavtartalmát a sejtbe injektálva elindíthassa lítikus sejtciklusát (Kim és Geider 2000). A holin és a lizozim (Koch és Dreyer 1958) olyan kisméretủ membránfehérjék, melyek a baktérium líziséhez járulnak hozzá: a holin nem-specifikus léziókat hoz létre a gazdasejt citplazmatikus membránjában (Bläsi és Young 1996), melyeken keresztül a lizozim a periplazmába juthat (Kim és mtsai. 2004). A 3. táblázatban feltüntetett 4-6. primer párok a $\Phi$ Ea116 fág különböző génjeinek meghatározott szakaszaira specifikusak: egy termináz, egy peptidáz, illetve egy Mu-szerü profág protein gént kódolnak. A dupla szálú DNS fág termináz a DNS elvágásával annak becsomagolási folyamatának elindításért felelős enzim (Black 1995). A peptidázok proteinek hasítását végző enzimek (Cheng és mtsai. 2004), míg a Mu-szerü profág (a gazdabaktérium kromoszómájába épült vírusgenom) protein az E. coli Mu1 temperált fágra (Taylor 1963) jellemző fehérje. A PEa1A/B primer pár a $\Phi$ Ea1h-ra, míg az Ea100F/R primer pár a $\Phi$ Ea100 fágtörzsre lett tervezve. A PEA1A/B primer pár a $\Phi E a 1 h$ fág genomjának a 10364-10667 nukleotidokra terjedő olyan szakaszát kódolja, amely részben egy $\mathrm{HNH}$ endonukleázt, illetve egy hipotetikus fehérjét határoz meg. Az Ea100F/R primer pár a ФEa100 genomjának a 10337-10662 bázispárig terjedő, részben egy HNH DNázt, illetve egy hipotetikus fehérjét, míg az Ea104F/R primer pár a $\Phi E a 104$ genomjának a 6271-tól a 6935 bázispárig terjedő, hipotetikus fehérjéket kódoló DNS szakaszára specifikus. Az Ea1hcapF/R primer pár az $\Phi \mathrm{Ea} 1 \mathrm{~h}$, a H2capF/R primer pár egy magyar fágtörzs, a $\Phi E a H 2$ (Dömötör és mtsai. 2012) kapszid proteint kódoló génjére specifikus. A kapszid (a vírus örökítőanyagát körülvevő fehérjeburok) protein a nukleinsav becsomagolásának folyamatában 
játszik szerepet (Xhu és Black 1990). A $\Phi E a H 2$ fágtörzsben fellelt, az E. amylovora egyik virulenciafaktorával, az ams $\mathrm{F}$ génnel nagyfokú hasonlóságot mutató génszakaszra terveztük a phiEaH2-F/R primerpárt, az EaFF/R primerek pedig az E. amylovora Ea7/74 (Bugert és Geider 1995) amsF génjére specifikusak.

\section{A vizsgálat módszere}

\section{Primertervezés}

Az egyes indító szekvenciák tervezését az amerikai fágok bizonyos DNS szakaszainak a nemzetközi gén adatbázisokból $\left(\right.$ GenBank $\left.^{\circledR}\right)$ ismert bázis sorrendje alapján az NCBI PrimerBLAST program segítségével végeztuik.

\section{A PCR vizsgálat menete}

\section{Mintaelökészités}

Az adott fágszuszpenzióból $100 \mu$ l-t a kettős agarlemez módszernél leírtaknak megfelelően sztreptomicinnel (300 ppm) kiegészített LBA táptalajra szélesztettünk, majd az Ea1/79Sm tesztbaktériumot tartalmazó fedőagar lemezen sötétben, $28^{\circ} \mathrm{C}$-on való inkubálást követően a másnapra kialakult önálló plakkokból egyet steril pipettaheggyel kiszúrtunk és a pipettahegyet $200 \mu 1$ steril bidesztillált vízbe áztattuk. Ezután $4 \mu \mathrm{l}$ (2\%) kloroform hozzáadásával és 10 perc szobahőmérsékleten történő inkubációs idő után lecentrifugáltuk $\left(4^{\circ} \mathrm{C}, 13500 \mathrm{rpm}, 10\right.$ perc $)$ a mintákat, végül a tiszta fágszuszpenziót tartalmazó felülúszót a felhasználásig $2 \%$ kloroformmal kiegészítve $4^{\circ} \mathrm{C}$-on tartottuk.

\section{Nátrium-azidos DNS feltárás}

Az egyes megtisztított fágszuszpenziók $50 \mu$ l-éhez hozzáadtunk $50 \mu 12 \mathrm{x}$ nátrium-azid $\left(\mathrm{NaN}_{3}\right)$ oldatot (2\% Triton $\mathrm{X}-100,0,5 \% \mathrm{NaN}_{3}, 0,1 \mathrm{~mol} 1^{-1}, \mathrm{pH}$ 8-as Tris pufferben). Vortex segítségével összekevertük, majd $99^{\circ} \mathrm{C}$-on 10 percig tartottuk. Ezt követően a szuszpenziót lehűtöttük és centrifugáltuk $4^{\circ} \mathrm{C}$-on $13500 \mathrm{rpm}$ fordulatszámon 10 percig. Az új Eppendorf csövekbe pipettázott felülúszó szolgált DNS templátként.

\section{PCR elegy összeállítása}

A $18 \mu 1$ végtérfogatú PCR elegyek $1 \mu$ l lizált fágsejt szuszpenziót, $9 \mu 1$ Thermo Scientific 2X PCR Master Mix-et (0,05 U/ $\mu \mathrm{L}$ Taq DNA polimeráz, reakció puffer, $4 \mathrm{mmol} \mathrm{l}^{-1} \mathrm{MgCl}_{2}$, és 4 mmol $1^{-1}$ az egyes dNTP-ből) és 4-4 $\mu 1$ 2,5 pmol $\mu \mathrm{l}^{-1}$ koncentrációjú primert tartalmaztak. 


\section{PCR program lefutása}

A reakció elegyek egy MJ Research PTC-200 Peltier Thermal Cycler PCR készülékben (GMI, Ramsey, MN, USA) az alábbiak szerint kerültek vizsgálatra.

MM2: (1) $94^{\circ} \mathrm{C}$-on 2 perc kezdő denaturálás, (2) $92^{\circ} \mathrm{C}$-on 1 perc denaturálás (a két komplementer DNS szál szétválása), (3) $47^{\circ} \mathrm{C}$-on 1 perc anellálás (a primerként szolgáló oligonukleotid homológ DNS szakaszhoz történő kapcsolódása), (4) $72^{\circ} \mathrm{C}$-on 1,5 perc elongáció (lánchosszabbítás), a reakció 2-4-ig terjedő szakasza 34x ismétlődik, (5) $72^{\circ} \mathrm{C}$-on 7 perc záró szintézis, majd $4^{\circ} \mathrm{C}$-on tartás.

MM3: (1) $95^{\circ} \mathrm{C}$-on 1 perc kezdő denaturálás, (2) $94^{\circ} \mathrm{C}$-on 30 másodperc denaturálás, (3) az adott primerpároknak megfelelő hőmérsékleten 30 másodperc anellálás, (4) $72^{\circ} \mathrm{C}$-on 30 másodperc elongáció, a reakció 2-4-ig terjedő szakasza 34x ismétlődik, (5) $72^{\circ} \mathrm{C}$-on 7 perc zárószintézis, majd $4^{\circ} \mathrm{C}$-on tartás.

\section{Gélelektroforézis}

A PCR termékek $10 \mu$ l-es mennyiségét $2 \mu$ 6x Loading Dye (Thermo Scientific) festékkel elegyítve GelRed-del (Biotium) festett 1\%-os agaróz (Invitrogen) gélben, vízszintes elektroforézis készülékben (Biorad, Power Pac Basic) választottuk el 90 V-on, 1x TAE pufferben. A felszaporított PCR termékek ellenörzésére $6 \mu \mathrm{l}$ markert (Thermo Scientific) futtatunk a minták mellett. A felszaporított nukleinsav szakaszokat áteső ultraibolya fényben fényképeztük (Alphaimager EP).

\subsection{SZEKVENCIA-ANALÍZIS}

\section{A vizsgálat anyaga}

Eddigi vizsgálataink hét hazai fágizolátumunk (H4A, H4B, H5A, H5B, H6A, H7A, H9B) genomjának depolimerázt kódoló szakaszaira és két hazai fágizolátum $(\mathrm{H} 2 \mathrm{~A}, \mathrm{H} 5 \mathrm{~K})$ genomjának részleges nukleotid sorrendjének meghatározására terjedtek ki. A H2A fágizolátum esetén a peptidáz, a Mu-szerủ profág protein és a termináz, a H5K fágnál a Mu-szerü profág protein és a termináz génekre specifikus indítószekvenciákkal PCR során felszaporított DNS szakaszokat vizsgáltuk.

\section{A vizsgálat módszere}

\section{PCR termék tisztítása szekvenáláshoz}

A mintánként $50 \mu 1$ mennyiségü PCR terméket PCR-M Clean Up System (Viogene) kittel a gyártó utasításai szerint tisztítottuk. A tisztított termékek DNS koncentrációját spektrofotometriás (nanodrop) méréssel (Nano maestrogen), $260 \mathrm{~nm}$ hullámhosszon, mintánként 
$2 \mu l$-t véve meghatároztuk. Ezt követően a PCR termékeket a szekvenálást végző labor elöírásainak megfelelő koncentrációra hígítottuk, és $15 \mu$ termékhez külön 2-2 $\mu$ l forward, illetve reverse primert $\left(10 \mu \mathrm{mol} 1^{-1}\right)$ adtunk.

\section{A nukleinsav szekvencia meghatározása és analízise}

Az előkészített mintákat megszekvenáltattuk, és a kapott nukleotid sorrendeket a BioEdit Biological Sequence Alignment Editor (www.mbio.ncsu.edu/bioedit.html) programmal értékeltük ki, majd az NCBI (National Center for Biotechnology Information) Nucleotide BLAST program (http://blast.ncbi.nlm.nih.gov/Blast.cgi) segítségével hasonlítottuk össze a GenBank adatbázisában (http://www.ncbi.nlm.nih.gov/nucleotide/) szereplő törzsek szekvenciáival.

\subsection{GAZDAKÖRVIZSGÁLAT}

A fágok gazdakörének vizsgálata nem csupán azt tárja fel, hogy az adott fágok milyen gazdabaktériumon képesek szaporodni, de egyúttal megteremti a lehetőséget a kórokozó baktériumra specifikus fágok elsődleges szelekciójához.

\section{A vizsgálat anyaga}

Tizenhat hazai fágizolátumunk (H1A, H1B, H2A, H2B, H4A, H4B, H5A, H5B, H6A, H7A, H7B, H8A, H9B, H10B, H11, H12B) és a négy amerikai fágtörzs (2. táblázat) gazdakörét vizsgáltuk.

Tesztorganizmusként 31 magyar és 8 külföldi E. amylovora izolátum, illetve törzs, 4 egyéb Erwinia faj, 6 Pantoea agglomerans törzs és 10 más növényi kórokozó baktérium faj, illetve törzs szolgált (1.a-b táblázat).

\section{A vizsgálat módszere}

\section{A tesztbaktériumok fágfogékonyságának megállapítása}

Az egyes baktérium tenyészeteket a számukra optimális tápoldatban (lásd 4.4 fejezet) 12 órán át rázattuk, majd titerüket egységesen $10^{8} \mathrm{CFU} \mathrm{ml}^{-1}$-re állítottuk be. Ezt követően az Adams-féle csepptesztet (lásd 4.5 fejezet) alkalmazva állapítottuk meg az adott tesztbaktérium fággal szembeni fogékonyságát. A teszthez 10-10 $\mu 10^{6} \mathrm{PFU} \mathrm{ml}{ }^{-1}$ koncentrációjú fáglizátumot használtunk. 
A tesztbaktériumok fogékonysága az indikátor baktériumot tartalmazó felső agar rétegen kialakult plakkok tisztasága alapján felállított háromfokozatú skálával került jellemzésre, ahol a '++' a tiszta plakkot; a '+' a homályos vagy zavaros plakkot és a '-' a plakk hiányát jelölte (9. ábra).

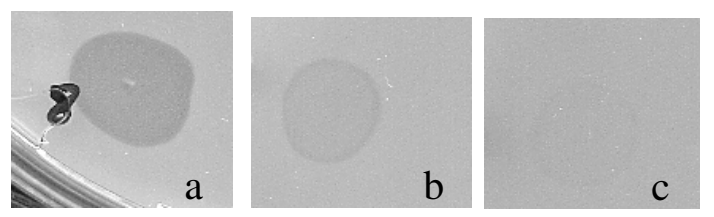

9. ábra A fágok gazdakörvizsgálata során megfigyelt különböző plakktípusok. ++ : tiszta plakk (a); + : homályos plakk (b); - : nincs plakk (c).

\subsection{FÁGOK ÉS FÁGKOMBINÁCIÓK ERWINIA AMYLOVORA BAKTÉRIUMRA GYAKOROLT HATÁSÁNAK VIZSGÁLATA}

\subsubsection{FÁG HATÁSVIZSGÁLAT FOLYADÉKKULTÚRÁBAN}

Fágizolátumaink E. amylovora elleni potenciális alkalmazásának felmérése céljából különböző hatásvizsgálatokat végeztünk in vitro körülmények között. Első lépésként a fágok és kombinációik baktériumszám-csökkentő hatását teszteltük folyadékkultúrában.

\section{A vizsgálat anyaga}

Tizenhat magyar fágizolátumunkat (H1A, H2A, H2B, H4A, H4B, H5K, H5B, H6B, H7A, H7B, H9A, H9B, H10A, H11, H12A, H12B) és meghatározott fágkombinációit (H2A+H5K, $\mathrm{H} 2 \mathrm{~A}+\mathrm{H} 7 \mathrm{~B}, \mathrm{H} 5 \mathrm{~K}+\mathrm{H} 7 \mathrm{~B}, \mathrm{H} 2 \mathrm{~A}+\mathrm{H} 5 \mathrm{~K}+\mathrm{H} 7 \mathrm{~B})$, valamint három amerikai fágtörzset (ФEa1h, ФEa100, ФEa116) vizsgáltunk.

Tesztbaktériumként sztreptomicin-rezisztens E. amylovora Ea1/79Sm törzset használtunk.

\section{A vizsgálat módszere}

\section{Bakteriofág-titerérték meghatározása}

Az egyes felszaporított és megtisztított fágszuszpenziókból SM pufferben százszoros hígítási sort készítünk, és csepptesztet végzünk oly módon, hogy a kiindulási fág törzsoldatnak (stock) és hígításainak 10-10 $\mu$ l-ét az Adams-féle dupla agarlemez módszerrel a tesztbaktériumot tartalmazó, megdermedt fedőagar rétegre pipettázzuk. Egynapos inkubáció után az önálló plakkokat adó hígításokat (2-4 db hígítást, szükség szerint) szélesztjük (100 $\mu$ l fágszuszpenziót $100 \mu 1$ tesztbaktériumot tartalmazó fedőagarban) és másnap a kialakult plakkok számából a hígítás mértékének ismeretében számítjuk ki a törzsoldat koncentrációját. 


\section{Hatásvizsgálat}

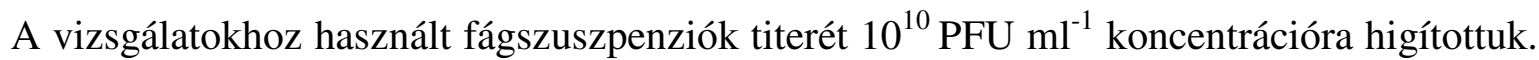
Üvegcsövekbe kimért folyékony LB táptalajban $1 \mathrm{ml}$ fágszuszpenziót, illetve az adott fágszuszpenziók kombinációjának 1:1 arányú keverékét és $1 \mathrm{ml} 10^{5} \mathrm{CFU} \mathrm{m{ } ^ { - 1 }}$ koncentrációjú tesztbaktériumot mértünk be, majd $28^{\circ} \mathrm{C}$-on 22 órán át rázattuk.

Az így kapott folyékony kultúrák fénytörését 600 nanométeren mértük, majd ezek alapján értékeltük a kísérletet. Minden kezelés három ismétlésben lett elvégezve. A kapott adatok statisztikai értékelése egytényezős varianciaanalízissel (one-way ANOVA) és azt követően a csoportok páronkénti összehasonlításához alkalmazott Tukey-féle HSD post hoc próbával történt.

\subsubsection{FÁG HATÁSVIZSGÁLAT ALMA- ÉS BIRSVIRÁGON}

Virágkísérlettel a természetes E. amylovora okozta elsődleges fertőzés helyén tudjuk vizsgálni a fágok hatékonyságát laboratóriumi körülmények között. A vizsgálat célja az, hogy egy-egy bakteriofág-izolátum, illetve kombinációjuk baktériumszám-csökkentő hatását összehasonlíthassuk.

\section{A vizsgálat anyaga}

\section{Virág}

Különböző tüzelhalás-fogékonyságú alma (Malus x domestica Borkh.) fajták ['Idared' (nagyon fogékony), 'Golden delicious Reinders' és 'Gala Schniga' (fogékony) (Lespinasse és Aldwinckle 2000); 'Pinova' (alig fogékony) (G. Tóth 1997)], és egy (fogékony) (Severin és mtsai. 1999) birsfajta (Cydonia oblonga 'Berecki') virágain teszteltük a fágok E. amylovora baktériumra gyakorolt hatását in vitro körülmények között. Az ollóval levágott, ballon fenofázisú virágok a BCE Gyümölcstermő Növények Tanszék soroksári kísérleti telepéről, illetve az MTA ATK NÖVI Herman Ottó úti szabadtéri konténeres gyümölcsfáiról származtak.

\section{Bakteriofágok és tesztbaktérium}

A folyadékkultúrás vizsgálatban leghatékonyabbnak bizonyult fágizolátumokat $(\mathrm{H} 2 \mathrm{~A}$, H5K és H7B) és azok hármas kombinációjának $(\mathrm{H} 2 \mathrm{~A}+\mathrm{H} 5 \mathrm{~K}+\mathrm{H} 7 \mathrm{~B})$ hatását teszteltük.

Az E. amylovora Ea1/79Sm törzset használtunk tesztbaktériumként. 


\section{A vizsgálat módszere}

\section{Patogenitás teszt}

Egy éjszakán át 500 ppm sztreptomicin-szulfátot tartalmazó LB tápoldatban felszaporított baktérium szuszpenzióval $\left(\mathrm{OD}_{600}=1,0=10^{9} \mathrm{CFU} \mathrm{ml}{ }^{-1}\right)$ egészséges dohánynövényen (Nicotiana tabacum L. 'Xanthi') patogenitás tesztet végeztünk (Klement 1963). Ezt követően a hiperszenzitív reakciót (HR-t) kiváltó, azaz igazoltan patogén kórokozót használtuk a virágok inokulálásához.

\section{Fágszuszpenziók előkészítése}

A fágokat először a korábbiakban leírtak szerint (lásd 4.5 fejezet) felszaporítottuk, tisztítottuk és szélesztettük, majd a 24 órás, majdnem egybefüggő plakkokat tartalmazó lemezekre 4-4 ml, zselatinos SM puffert öntöttünk és a Petri csészéket sötétben, 22-23 ${ }^{\circ}$ C-on 4 órán keresztül rázattuk (Mini Rocker MR-1, Biosan). Ezt követően az így továbbszaporított fágokat tartalmazó szuszpenziót lepipettáztuk a felső táptalajrétegről és további 1-1 ml SM pufferrel lemostuk az agarlemezt. Az összegyüjtött fágszuszpenziót 2\% végtérfogatú kloroformmal tisztítottuk, centrifugáltuk $\left(13500 \mathrm{rpm}, 10\right.$ perc, $\left.4^{\circ} \mathrm{C}\right)$, majd a fágszuszpenziót képző felülúszó titerét meghatároztuk, és a szuszpenziót felhasználásig sötétben, $4^{\circ} \mathrm{C}$-on tartottuk.

\section{A virágok előkészítése}

A virágokat 4-4 ml 1\%-os szacharóz oldattal feltöltött csövekbe helyeztünk, melyeket előzetesen kilyuggatott hungarocell lapokba állítottunk. Végül a lapokat $200 \mathrm{ml}$ 87\%-os glicerines oldattal felöntött, sterilizált (10\%-os hypo, háromszori steril desztillált vízzel való öblítés, UV fény alatti szárítás 20 percig), átlátszó műanyag dobozokba helyeztük és kb. 12 órán át inkubáltuk növénynevelö kamrában (Binder KBW), míg az összes virág ki nem nyílt.

\section{A virágok kezelése}

A kinyílt virágok bibéjére egy időben pipettával juttattuk ki a fáglizátum $\left(10^{12} \mathrm{PFU} \mathrm{ml^{-1 }}\right)$ és baktérium-szuszpenzió ( $\left.5 \times 10^{5} \mathrm{CFU} \mathrm{ml}^{-1}\right)$ 1:1 arányú keverékét $20 \mu$ l végtérfogatban (10. ábra) az alábbi kezelések szerint: (A) H2A+Ea1/79Sm baktérium (a későbbiekben Ea), (B) H5K+Ea, (C) H7B+Ea, (D) (H2A+H5K+H7B)+Ea, (Ea) Ea+víz, $\left(\mathrm{H}_{2} \mathrm{O}\right)$ víz. 
A kezeléseket követően az inkubáció a lefedett dobozokban, 16/8 óra fény/sötét és 22$23^{\circ} \mathrm{C} / 19-20^{\circ} \mathrm{C}$ nappali/éjszakai hőmérséklet mellett történt 4 napig, növénynevelő kamrában (Binder KBW).

Almafajtánként és kezelésenként 15-15 (az erviniás kontroll esetében 20-20) virágot használtunk. A kísérletet két ismétlésben végeztük.

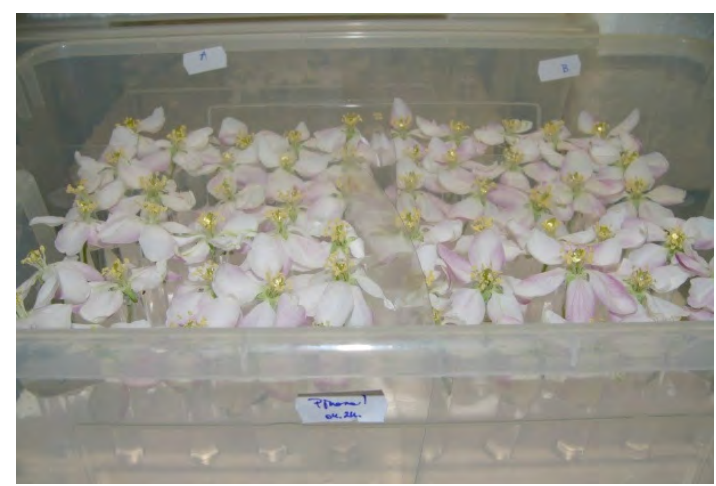

10. ábra Fág hatásvizsgálat alma és birsvirágon: almavirágok ('Pinova') közvetlenül a kezelések után.

\section{Baktérium-visszaizolálás}

A fertőzést követő négy nap elteltével a virágokról eltávolítottuk a szirmokat, levágtuk a virágszárat és bibékkel lefelé, egyenként steril (1,5 ml-es) Eppendorf csövekbe helyeztük őket. Egy $\mathrm{ml}$ steril bidesztillált vizet pipettáztunk rájuk, majd 10 perc $22-23^{\circ} \mathrm{C}$-on való inkubációt követően centrifugáltuk (3 perc, 13500 rpm) (11. ábra), és végül óvatosan kivettük a csövekböl a virágokat. Az így kapott vizes szuszpenzió szolgált mintaként.

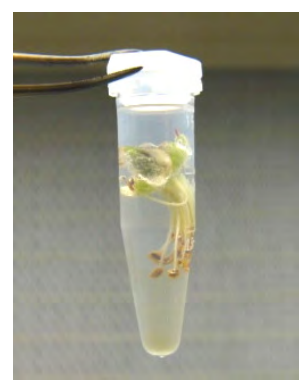

11. ábra Fág hatásvizsgálat alma és birsvirágon: a baktérium-visszaizolálás lépéseként a kezelt virágok steril desztillált vízben való inkubációja Eppendorf-csőben.

\section{A kísérlet értékelése}

\section{a) Baktériumsejt-számlálás}

A baktérium-visszaizolálási folyamat végén nyert vizes szuszpenziót vortex segítségével összekevertük és hígítottuk, majd $50 \mu \mathrm{l}$ 10000-szeres hígítású vizes baktérium-szuszpenziót antibiotikum [500 ppm sztreptomicin és 50 ppm cikloheximid (SIGMA)] tartalmú LBA táptalaj 
felszínére pipettáztunk, majd lelángolt és 70\%-osra higított etanolban (Reanal) lehütött, Lalakban hajlított üvegbottal szélesztettük.

Két nap, $28^{\circ} \mathrm{C}$-on, termosztátban való inkubációt követően a kialakult telepek száma alapján értékeltük az adott kísérletet. Két egymást követő év adatai kerültek statisztikailag kielemzésre többszörös varianciaanalízis (MANOVA), illetve ANOVA és Tukey-féle HSD próba alapján.

\section{b) Valós idejü PCR vizsgálat}

Az 'Idared' fajta 2012-es mintáiban az E. amylovora titerét valós idejü (,real time”) PCR alkalmazásával is vizsgáltuk, majd a kapott eredményeket összevetettük a baktériumtelepszámlálási adatokkal.

\section{A referencia baktérium-koncentráció meghatározása}

Egyéjszakás (500 ppm sztreptomicint tartalmazó LB tápoldatban $28^{\circ} \mathrm{C}$-on rázatva felszaporított) Ea1/79Sm E. amylovora baktérium-szuszpenziót $\mathrm{OD}_{600}=1,5$ értékre beállítunk, majd abból 8 tagú tizedelő hígítási sort készítettünk steril bidesztillált vízben. Az egyes hígításokból 50-50 $\mu$ l-t, lelángolt üvegbottal, sztreptomicint (500 ppm) tartalmazó LBA táptalajra szélesztettünk, majd két napos inkubációt $\left(28^{\circ} \mathrm{C}\right.$, termosztát) követően a kifejlődött kolóniák számából meghatároztuk az egyes hígítások titerét.

\section{Mintaelökészités}

A viszonyítási alapul szolgáló E. amylovora kontrollhígításokat és az 'Idared' kezelt virágairól a visszaizolálási procedúra végén nyert mintákat a korábban (lásd 4.7 fejezet) ismertetett módon Na-aziddal feltártuk, majd elvégeztük valós idejü PCR vizsgálatukat. A referencia E. amylovora minták koncentrációját a korábban (lásd 4.7 fejezet) említett módon gélelektroforézissel is ellenőriztük. Az egyes fág kezeléseknél 15-15 biológiai ismétléssel, az $E$. amylovora kontroll esetében 20 párhuzamossal dolgoztunk.

\section{PCR elegy összeállitása}

A $18 \mu$ l végtérfogatú PCR elegyek $1 \mu$ l lizált fágsejt szuszpenziót, $9 \mu$ l kétszeres KAPA SYBR®FAST Master Mix-et (KAPA SYBR ${ }^{\circledR}$ FAST qPCR Kit Master Mix (2X) Universal, KAPA Biosystems, Wilmington, MA, USA) és 4-4 $\mu 1$ 2,5 pmol $\mu 1^{-1}$ koncentrációjú primereket tartalmaztak. A P29TF (5' CACTGATGGTGCCGTTG $3^{\prime}$ ) és a P29TR (5' CGCCAGGATAGTCGCATA 3') primerek (Salm és Geider 2004) az E. amylovora-ra jellemző 
pEA29 plazmidra specifikusak. A minták vizsgálatát Real-Time PCR készülék (BIO-RAD, C1000Touch ${ }^{\mathrm{TM}}$ Thermal Cycler, CFX96 ${ }^{\mathrm{TM}}$ Real-Time System) segítségével végeztük.

\section{PCR program lefutása és kiértékelése}

P29: (1) $95^{\circ} \mathrm{C}$-on 3 perc kezdő denaturálás, majd 40x [(2) $94^{\circ} \mathrm{C} 20$ másodperc, (3) $52^{\circ} \mathrm{C} 20$ másodperc, (4) $72^{\circ} \mathrm{C} 20$ másodperc] (5) melting analízis $\left(65^{\circ} \mathrm{C}-95^{\circ} \mathrm{C}, 0,5^{\circ} \mathrm{C}\right.$-ként felvételezve), (6) $10^{\circ} \mathrm{C}$-on tartás.

A SYBRGreen interkalálódó festék, vagyis a DNS kettős szálak árkaiba kötve gerjeszthető. A kibocsátott fluoreszcens jelek ciklusonkénti felvételezése nyomán a program egy szigmoid görbét szerkeszt, mely a fluoreszcenciát a ciklusszámok függvényében ábrázolja. A program ezután a görbék együttesére egy a fluoreszcencia tengelyre merőleges egyenest illeszt, mely minden görbét már az exponenciális szakaszban metsz. Ez a fluoreszcencia küszöbérték. Az ehhez tartozó ciklusszámot Cq értékként jelölve jeleníti meg a program (Bustin 2009). Ezeket az értékeket összevetve egy ismert koncentrációjú E. amylovora szuszpenzió hígítási sorából nyert görbékkel kaptuk meg a relatív koncentrációkat, azaz az egyes minták egymáshoz viszonyított templát tartalmát. A méréseket 3 ismétlésben végeztük. A kapott termékhosszat agaróz gélen ellenőriztük, a későbbiekben pedig az olvadási görbéjük alapján is igazoltuk, hogy a mérések során a megfelelő termék lett vizsgálva.

\subsubsection{FÁG HATÁSVIZSGÁLAT ÉRETLEN KÖRTESZELETEN}

A fágok és fágkombinációk hatásvizsgálatát - az antagonista mikroorganizmusok tesztelésénél is használatos - éretlen, zöld körteszeleteken is elvégeztük.

\section{A vizsgálat anyaga}

\section{Körtegyümölcs}

Jelen munkánkban három körte (Pyrus communis L.) fajtával ('Conference', 'Dr. Guyot Gyula' és 'Erdei vajkörte') dolgoztunk, melyek éretlen körte gyümölcsei az OMMI pölöskei Fajtakísérleti Állomásáról származtak.

\section{Bakteriofágok, tesztbaktérium, antibiotikum}

A virágkísérletek során is tesztelt fágizolátumok (H2A, H5K és H7B) és azok hármas kombinációjának $(\mathrm{H} 2 \mathrm{~A}+\mathrm{H} 5 \mathrm{~K}+\mathrm{H} 7 \mathrm{~B})$ baktérium-visszaszorító hatását teszteltük. 
A fertőzéshez az Ea1/79 vad típusú ervinia törzset használtuk, hogy az E. amylovora elleni védekezési kísérletekben „gold standard”-ként alkalmazott sztreptomicin-szulfát hatásával is össze tudjuk hasonlítani az egyes fágkezelések hatékonyságát.

A sztreptomicin antibiotikumot 100 ppm-es koncentrációban használtuk.

\section{A vizsgálat módszere}

\section{Patogenitás teszt}

A mesterséges bakteriális inokulációhoz a virágkísérletekben ismertetett módon (lásd 4.10.2 fejezet) ellenőriztük a tesztbaktérium patogenitását.

\section{A körteszeletek kezelése}

A $0,5 \mathrm{~cm}$ vastagságúra vágott éretlen, zöld körteszeleteket (6 darab/kezelés) üveg Petri csészékben elhelyezve (12. ábra) az adott kezelésnek megfelelő $10 \mathrm{ml}$ fágszuszpenzióban (10 ${ }^{12}$ PFU ml ${ }^{-1}$ ), vízben, illetve sztreptomicin oldatban (100 ppm) áztattuk oldalanként 5-5 percig, majd mesterségesen inokuláltuk a kórokozó baktérium $10 \mu$ l-ét $\left(5 \times 10^{5} \mathrm{CFU} \mathrm{ml}^{-1}\right)$ a szeletek közepére pipettázva. Az egyes kezelések a következőek voltak: (A) H2A+Ea1/79 baktérium (a későbbiekben Ea), (B) H5K+Ea, (C) H7B+Ea, (D) $(\mathrm{H} 2 \mathrm{~A}+\mathrm{H} 5 \mathrm{~K}+\mathrm{H} 7 \mathrm{~B})+\mathrm{Ea},(\mathrm{Ea})$ víz+Ea, $\left(\mathrm{H}_{2} \mathrm{O}\right)$ víz, (Sm) sztreptomicin+Ea.

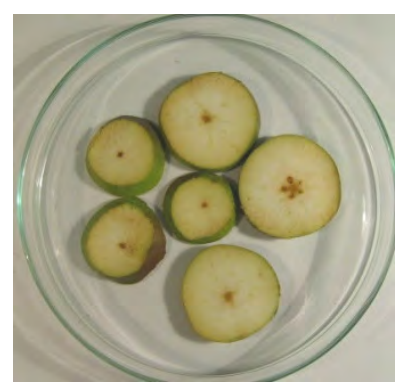

12. ábra Fág hatásvizsgálat éretlen körteszeleteken: körteszeletek ('Erdei vajkörte') üveg Petri csészében a kezelést megelőzően.

A kezeléseket követő 4 napos inkubáció a lefedett Petri csészékben 16/8 óra fény/sötét és $22-23^{\circ} \mathrm{C} / 19-20^{\circ} \mathrm{C}$ nappali/éjszakai hőmérséklet mellett történt növénynevelő kamrában (Binder KBW).

\section{A kísérlet értékelése}

Az inkubációt követően a fertőzés eredményeként megjelent tünetek súlyosságát egy előre felállított bonitálási skála alapján értékeltük, ahol az egyes értékek a következőknek feleltek meg: (0) tünetmentes; (1) az inokuláció helye körül a szelet közepe barna, nyálkacseppes; majd 
fokozódó nyálkakiválás mellett (2) az 1/8 része barna; (3) az 1/4 része barna; (4) az 1/2 része barna; (5) a 3/4 része barna; (6) a szelet egésze barna (13. ábra).
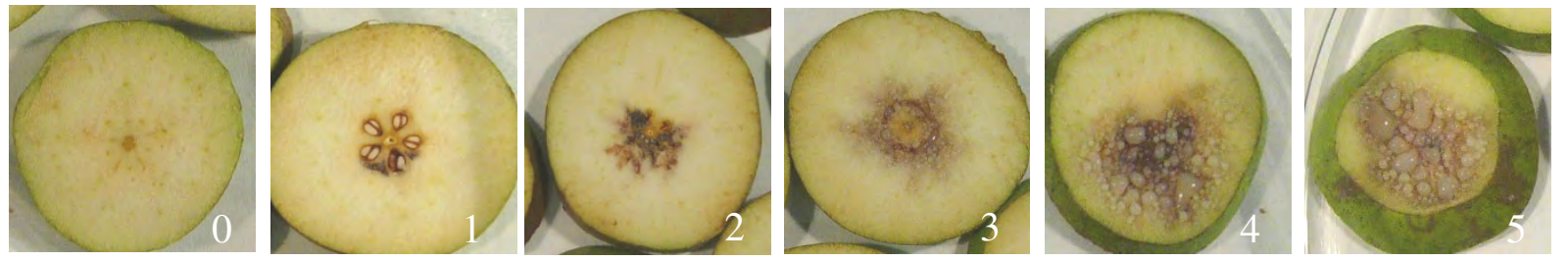

13. ábra Éretlen körteszeleteken végzett fág hatásvizsgálat - bonitálási skála 0-tól 5-ig (6-os skála nem volt megfigyelhető az inkubációs időn belül).

\subsubsection{FÁG HATÁSVIZSGÁLAT DÍSZNÖVÉNYEKEN}

Ebben a vizsgálatban az alábbi, E. amylovora baktériumra fogékony (Lespinasse és Aldwinckle 2000) növényfajok képezték a tesztnövények körét: tüztövis [Pyracantha angustifolia (Franch.) Schneid. sp.], kerti madárbirs (Cotoneaster horizontalis Decne sp.), házi berkenye (Sorbus domestica L. sp.) és egybibés galagonya (Crataegus monogyna Jacq. sp.).

A teljes virágzásban lemetszett vesszők egy solymári (Pest megye) magánkertből származtak.

\section{A vizsgálat anyaga}

\section{Bakteriofágok és tesztbaktérium}

A vizsgálatban a $\mathrm{H} 2 \mathrm{~A}, \mathrm{H} 4 \mathrm{~A}$ és $\mathrm{H} 5 \mathrm{~A}$ fágizolátumok, valamint azok hármas kombinációjának (H2A+H4A+H5A) baktérium-visszaszorító hatását teszteltük.

A fertőzéshez az E. amylovora Ea1/79Sm törzset használtuk.

\section{A vizsgálat módszere}

\section{Patogenitás teszt}

A mesterséges bakteriális inokulációhoz a virágkísérletekben ismertetett módon (lásd 4.10.2 fejezet) ellenőriztük a tesztbaktérium patogenitását.

\section{A virágok kezelése}

A vízzel teli Erlenmeyer lombikba helyezett lemetszett virágos vesszők az egyes fágizolátumokkal külön-külön, illetve ezek kombinációjának vizes szuszpenziójával $\left(10^{4} \mathrm{PFU}\right.$ $\left.\mathrm{ml}^{-1}\right)$, majd 20 perc elteltével baktérium-szuszpenzióval $\left(10^{9} \mathrm{CFU} \mathrm{ml^{-1 }}\right)$ lettek lepermetezve. $\mathrm{Az}$ egyes kezelések a következők voltak: (A) H2A+E. amylovora (Ea), (B) H4A+Ea, (C) H5A+Ea, (D) $(\mathrm{H} 2 \mathrm{~A}+\mathrm{H} 4 \mathrm{~A}+\mathrm{H} 5 \mathrm{~A})+\mathrm{Ea}$, (Ea) $\mathrm{H}_{2} \mathrm{O}+\mathrm{Ea}$ (pozitív kontroll). 
A kezeléseket követő 4 napos inkubáció $16 / 8$ óra fény/sötét és $22-23^{\circ} \mathrm{C} / 19-20^{\circ} \mathrm{C}$ nappali/éjszakai hőmérséklet mellett történt növénynevelö kamrában (Binder KBW).

\section{A kísérlet értékelése}

A fágkezelések baktérium-elimináló hatása a szerint került értékelésre, hogy 100 véletlenszerủen kiválasztott virágból hány darabnál volt megfigyelhető vacokbarnulás (fertőzés $\%)$ a fertőzést követő negyedik napon.

\subsection{A FÁGKEZELÉS HATÉKONYSÁGÁNAK FOKOZÁSÁRA IRÁNYU- LÓ VIZSGÁLATOK: FÁGOK NÖVÉNYBE JUTÁSA, TRANSZLOKÁ- CIÓJA ÉS AZ E. AMYLOVORA OKOZTA TÜNETEKRE GYAKOROLT HATÁSA}

Igazolt, hogy a fág alapú biológiai védekezés egyik nehézségét képezi a fágok nagyfokú érzékenysége a változó és szélsőséges környezeti körülményekhez. Azonban a fágok életképességét és ezáltal a fágkezelések hatékonyságát nagyban megnöveli például a fágok UVfénnyel szembeni védelme. Annak tisztázására, hogy fennáll-e a lehetőség ezt a fajta védelmet azáltal biztosítani, hogy a fágokat közvetlenül a védendő növénybe juttatjuk, különböző transzlokációs és hatásvizsgálatokat állítottunk be.

\section{A vizsgálat anyaga}

\section{Bakteriofágok és tesztbaktérium}

A H5K jelzésű hazai fágizolátumot és az amerikai ФEa104 fágtörzset használtuk ezekben a kísérletekben.

A fágok felszaporításához, kimutatásához, valamint a hatásvizsgálatoknál végzett baktériumos inokulációhoz az Ea1/79Sm E. amylovora törzset használtuk.

\section{Tesztnövények}

A vizsgálatokhoz Malus x domestica Borkh. 'Pinova' magoncokat használtunk. A 'Pinova' almafajta magjait, melyeket áru almagyümölcsből nyertünk, csíráztatás előtt 20\%-os hypo oldatban 10 percig áztatva, majd háromszor, steril csapvizzel leöblítve felületileg sterilizáltuk. Ezt követően a Petri csészében steril csapvízzel átitatott perlitre helyezett magokat $4^{\circ} \mathrm{C}$-on, hütőszekrényben, sötétben tartottuk 6-8 hétig, majd a fiatal csíranövényeket külön-külön, vízzel átitatott, perlittel feltöltött $10 \mathrm{~cm}$ magas üvegedényekbe ültettük és mủanyagdobozba helyeztük. 
A növényeket steril körülmények között növénynevelö kamrában neveltük tovább (16/8 óra fény/sötét és $20^{\circ} \mathrm{C} / 18^{\circ} \mathrm{C}$ nappali/éjszakai hőmérséklet).

Valamennyi kísérlet lefolyása steril áttetsző, müanyag dobozokban, 16/8 óra fény/sötét és $22-23^{\circ} \mathrm{C} / 19-20^{\circ} \mathrm{C}$ nappali/éjszakai hőmérséklet mellett történt növénynevelő kamrában (Binder KBW).

\section{A vizsgálat módszere}

\section{Fágdetektálás}

A fágok kimutatásához az Adams-féle cseppteszt módosított változatát használtuk: a 100 $\mu l$ tesztbaktériumot tartalmazó LBA fedőlemez közepére $100 \mu$ l fáglizátumot cseppentettünk. Az egy napig sötétben, $28^{\circ} \mathrm{C}$-on történő inkubációt követően került sor a fágok meglétének, illetve hiányának a megállapítására, a fágok jelenlétére utaló, a baktériumrétegen megjelenő plakkok alapján.

\section{Az adatok statisztikai kiértékelése}

A kísérleteket két ismétlésben végeztük. A kísérleti adatok statisztikai elemzése egytényezős varianciaanalízissel (one-way ANOVA) és azt követően Tukey-féle HSD post hoc próbával történt.

\subsubsection{A FÁGOK TRANSZLOKÁCIÓS KÉPESSÉGÉNEK ALMA CSÍRANÖVÉNYEKBEN TÖRTÉNŐ VIZSGÁLATA - ELÖKÍSÉRLET}

\section{A vizsgálat anyaga}

A H5K fágizolátum gyökéren keresztül való felvételét teszteltük steril körülmények között nevelt öt hónapos almamagoncokon.

\section{A vizsgálat módszere}

A tesztnövények egy részét steril bidesztillált vizet tartalmazó üvegedénybe (hidroponikus kultúra) helyeztük, más részük a növénynevelő perlites közegben maradt. Kezelésenként öt-öt növényt használtunk. A hidroponikus vizsgálatnál $30 \mathrm{ml}$, a perlitbe helyezett magoncoknál $10 \mathrm{ml}$ $10^{13} \mathrm{PFU} \mathrm{m} \mathrm{m}^{-1}$ koncentrációjú vizes fágszuszpenziót adtunk egy-egy növényhez. A kontroll növények sterilizált bidesztillált vizet kaptak. Az egyszeri kezelést követően két időpontban (három-három növényböl a második napon, két-két növényböl a hatodik napon) vettünk mintát, a növények felső szárrészét és leveleit együttesen feltárva steril dörzsmozsárban, SM pufferben elhomogenizálva a növény szöveteit (14. ábra). Számolva azzal, hogy a kijuttatott 
fágszuszpenzió titere esetleg a közvetlen visszaizolálással kimutatható szint alá süllyed, a kétnapos inkubáció után vett minták 200-200 $\mu$ l-ét további négy napig, baktériumkultúrával (10 $\mathrm{CFU} \mathrm{m} \mathrm{m}^{-1}$ ) LB (sztreptomicin 500 ppm) tápoldatban együtt rázattuk.

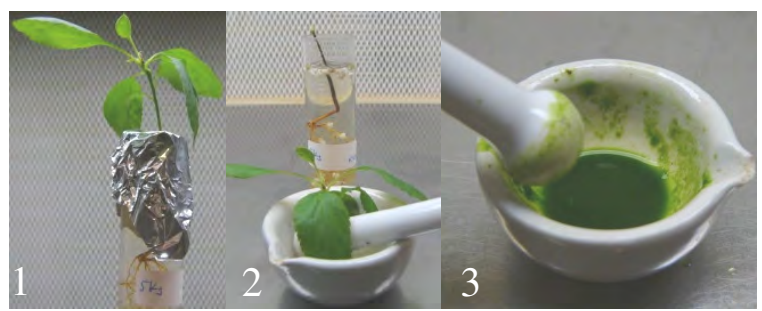

14. ábra A fágok transzlokációs képességének alma csíranövényekben történő vizsgálata - előkísérlet.

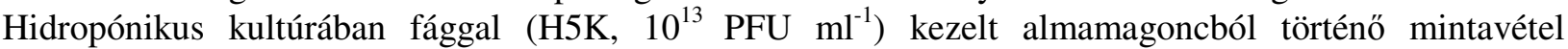
folyamata: (1) növényi minta; (2) a feltárandó növényi részek lemetszése; (3) a lemetszett minta homogenizálása.

\subsubsection{FÁGOK SZÁLLÍTÓDÁSA ALMA CSÍRANÖVÉNYEKBEN}

\section{A vizsgálat anyaga}

Kísérletünkben a ФEa104 fágtörzset és a H5K fágizolátumot használtuk, 17-18 hetes almamagoncokon.

\section{A vizsgálat módszere}

\section{A tesztnövények kezelése}

A fágszuszpenziók $\left(10^{13} \mathrm{PFU} \mathrm{ml}^{-1}\right)$ kétféle módon lettek kijuttatva a tesztnövényekhez: a perlit felszínére, a gyökérzónához pipettázva (10 ml/növény), illetve a növény föld feletti részére permetezve (500 $\mu 1 /$ növény), egy alkalommal. Ez utóbbi kezelést megelőzően a növényt tartalmazó edény szája alufóliával és parafilmmel le lett zárva (15. ábra). A kontroll növények steril desztillált vizet kaptak. A kezelésenkénti 15 növényből 3-3 szolgált mintául, 1, 2, 3, 5 és 7 nappal a kezelést követően. A kontroll esetében csak az első napon történt mintavétel. A gyökérzóna kezelése esetén mintavételkor külön a növények alsó, sziklevél alatti, illetve a felső, leveles szárrésze, míg a föld feletti részekre való kipermetezést követően a növények gyökérzete lett feltárva SM pufferben, steril mozsárban elhomogenizálva az egyes mintákat. 


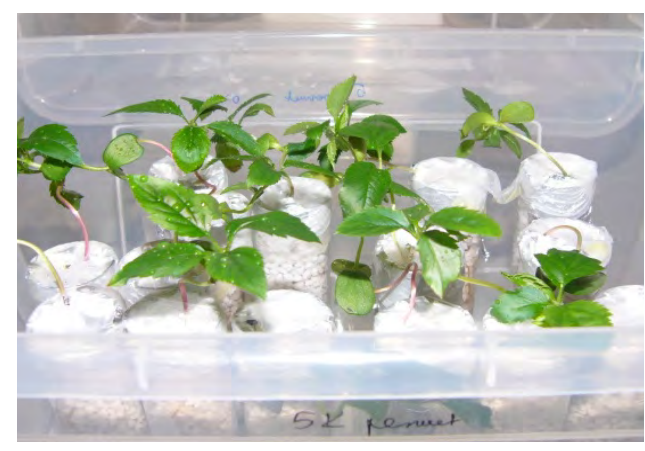

15. ábra Fágtranszlokációs teszt során a fágok tesztnövényekhez való kijuttatása: alma csíranövények közvetlenül a H5K fágszuszpenzióval $\left(10^{13} \mathrm{PFU} \mathrm{ml}^{-1}\right)$ történő lepermetezést (500 $\mu \mathrm{l} /$ növény) követően.

\section{A fágok kimutatása}

a) Az Adams-féle cseppteszt módosított változatával történt közvetlenül a mintavétel után, illetve további két napon át tartó fág-felszaporítási eljárást követően.

b) A szélesztéssel plakkot adó pozitív mintákban a fágok jelenlétét PCR módszerrel is vizsgáltuk. A DNS feltárás 2x Na-aziddal, a korábbiakban leírtak szerint (lásd 4.7 fejezet) történt. A PCR során két primer párt használtunk. A Term-F és a Term-R indító szekvenciák (3. táblázat) a H5K fágizolátum, míg az Ea104F és Ea104R primer pár (3. táblázat) a $\Phi E a 104$ fágtörzs egy-egy meghatározott DNS szakaszának felszaporításával szolgáltak az adott fág kimutatására.

PCR elegy összeállítása

A $18 \mu$ l végtérfogatú PCR elegyek a már korábban ismertetett módon (lásd 4.7 fejezet) lettek összeállítva.

PCR program lefutása

A Term-F/R primerpár esetében az MM2, az Ea104F/R primer párral végzett PCR alkalmával az MM3 program szerint (lásd 4.7 fejezet) történt a minták molekuláris vizsgálata.

Gélelektroforézis

A PCR termékek kimutatásakor a 4.7 részben leírtak alapján jártunk el.

\subsubsection{A FÁGOK HATÁSA AZ E. AMYLOVORA OKOZTA TÜNETEKRE}

\section{A vizsgálat anyaga}

Ezekben a fág hatásvizsgálatokban a EEa104 fágtörzset és a H5K fágizolátumot használtuk. 


\subsubsection{Alma csíranövények gyökérzónájához, illetve föld feletti részeire juttatva ki a fágokat}

\section{A vizsgálat anyaga}

Húsz hetes almanövények szolgáltak tesztnövényként.

\section{A vizsgálat módszere}

\section{A tesztnövények kezelése}

A hatásvizsgálatok sorában először a transzlokációs kísérlethez hasonló módon juttattuk ki a fágokat: a tesztnövények gyökérzónájához pipettázva $(12 \mathrm{ml})$, illetve a növények lombozatára permetezve (körülbelül $500 \mu \mathrm{l} /$ növény) az adott fágszuszpenziót $\left(10^{3}\right.$, illetve $\left.10^{13} \mathrm{PFU} \mathrm{ml}{ }^{-1}\right)$.

A fágkezelést követő első napon a negatív kontrollok kivételével mesterségesen megfertőztük a magoncokat: $10 \mu \mathrm{l}$ baktérium-szuszpenziót $\left(5 \times 10^{5} \mathrm{CFU} \mathrm{\textrm {ml } ^ { - 1 }}\right)$ pipettáztunk a második-harmadik legfiatalabb levél hónaljába, majd steril injekciós tủvel a baktériumcseppen keresztül megszúrtuk a növény szövetét (16. ábra). Az egyes kezelések a következők voltak: (A) víz, (B) fág kijuttatása és vízzel történő inokuláció, mint negatív kontrollok, (C) fágkezelés egy nappal a baktériumos inokulációt megelőzően (H5A+Ea és $\Phi E a 104+E a)$, és (D) víz kijuttatása az inokuláció előtt egy nappal $\left(\mathrm{H}_{2} \mathrm{O}+\mathrm{Ea}\right)$ a pozitív kontrollként. Fágizolátumonként három növény vett részt egy-egy kezelésben mindkét alkalmazott fágszuszpenzió-koncentráció esetén.

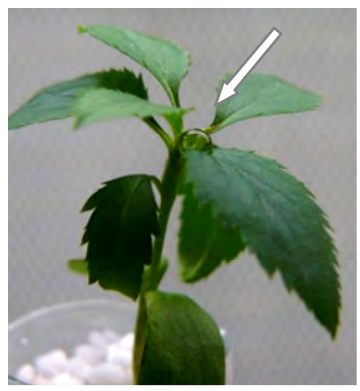

16. ábra A fágok hatása az E. amylovora okozta tünetekre alma csíranövények gyökérzónájához, illetve föld feletti részeire juttatva ki a fágokat - a kezelést követő napon végzett bakteriális inokuláció (Ea1/79Sm, $10 \mu \mathrm{l}, 5 \times 10^{5} \mathrm{CFU} \mathrm{ml}{ }^{-1}$ ). A nyíl a baktériumcsepp és a tüszúrás helyét mutatja.

\section{A kísérlet értékelése}

A kialakult betegségtünetek mértékét a fertőzést követő 5. és 13. napon egy 0-5-ig terjedő bonitálási skála alapján értékeltük, ahol az egyes értékek a következőket jelentik: (0) nincs tünet; (1) a fertőzés helye barnás fekete; $(1,5)$ a fertőzés helye körül a levélnyél 1/3 része barnás fekete;

(2) a fertőzés helye körül a levélnyél $1 / 2$ része barnás fekete és hervadt a növény; $(2,5)$ a teljes levélnyél barnás fekete és hervadás jellemző; (3) a fertőzés helye körül a szár is barnás fekete; $(3,5)$ a növény $1 / 4$ részére kiterjedt nekrózis; (4) a növény $1 / 3$ részére kiterjedt nekrózis; $(4,5)$ a növény $1 / 2$ részére kiterjedt nekrózis; (5) széles körü nekrózis. 


\subsubsection{A fágokat alma csíranövények sziklevelébe injektálva}

\section{A vizsgálat anyaga}

Nyolc hetes alma csíranövények szolgáltak tesztnövényként.

\section{A vizsgálat módszere}

\section{A tesztnövények kezelése}

Ebben a kísérletben a fágok vizes szuszpenziója $\left(10^{13} \mathrm{PFU} \mathrm{ml}^{-1}\right)$ a tesztnövények egyik sziklevelébe lett juttatva: a sziklevelet először steril injekciós tűvel megszúrva majd az adott szuszpenziót a növény szövetébe injektálva. Közvetlenül ez után (a negativ kontrollok kivételével) megfertőztük a növényeket $10 \mu \mathrm{l}$ baktérium szuszpenziót $\left(10^{6} \mathrm{CFU} \mathrm{ml}^{-1}\right)$ cseppentve a fágok oldatával teljesen átitatott sziklevelek színére, majd a cseppen keresztül ismét megszúrtuk a növény szövetét. A következő kezeléseket alkalmaztuk: (A) víz injektálva és a levélre cseppentve, (B) fág injektálva és vizet cseppentve (negatív kontrollok), (C) fág injektálva és baktérium-szuszpenzió cseppentve (H5K+Ea és $\Phi E a 104+E a)$, valamint (D) víz injektálva, majd baktérium-szuszpenzió a levélre cseppentve $\left(\mathrm{H}_{2} \mathrm{O}+\mathrm{Ea}\right)$ (pozitív kontroll). Fágizolátumonként öt növény vett részt egy-egy kezelésben.

\section{A kísérlet értékelése}

Egy öt napos inkubációs időszakot követően a szikleveleken kialakult tűzelhalás tünetek mértékét megfigyeltük és a következő, 0-5-ig terjedő bonitálási skála alapján értékeltük (17. ábra): (0) ép, zöld sziklevél; $(0,5)$ apró, nekrotikus foltok a fertőzés helyén; (1) a kezelt sziklevél 1/6 része barna; (1,5) a kezelt sziklevél 1/5 része barna (2) a kezelt sziklevél 1/4 része barna; $(2,5)$ a kezelt sziklevél $1 / 3$ része barna (3) a kezelt sziklevél 1/2 része barna; $(3,5)$ a kezelt sziklevél 3/4 része barna; (4) az egész kezelt sziklevél barna; (4,5) a kezeletlen sziklevél is barnult; (5) mindkét sziklevél barna.
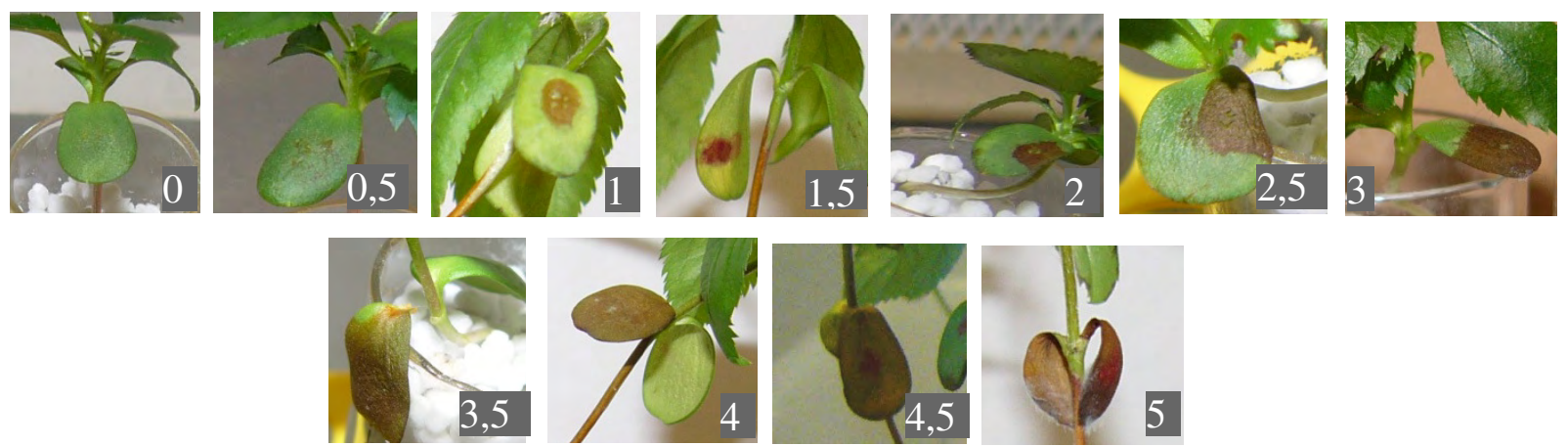

17. ábra A fágok hatása az E. amylovora okozta tünetekre a fágokat alma csíranövények sziklevelébe injektálva - bonitálási skála. 


\section{EREDMÉNYEK}

\subsection{FÁGIZOLÁTUMOK}

Összesen 22 fágizolátummal rendelkezünk, amelyeket Magyarország különböző földrajzi területeiről gyűjtött alma, körte és birs fák erviniás tüneteket mutató növényi részeiről izoláltunk. Ezek közül eddig 16 izolátum lett széles körüen is megvizsgálva (4. táblázat).

4. táblázat Hazai fágizolátumok származási adatai

\begin{tabular}{|c|c|c|}
\hline Fágizolátum & Növény & Gyüjtés helye, ideje \\
\hline H1A, H1B & birs (Cydonia oblonga Mill.) levél, ág, termés & Siófok, 2007 \\
\hline $\mathrm{H} 2 \mathrm{~A}, \mathrm{H} 2 \mathrm{~B}$ & birs (Cydonia oblonga Mill.) virág & \multirow{3}{*}{ Békéscsaba, 2006} \\
\hline H4A, H4B & birs (Cydonia oblonga Mill.) levél, termés & \\
\hline $\begin{array}{l}\text { H5A, H5B, } \\
\text { H5K }\end{array}$ & birs (Cydonia oblonga Mill.) virág & \\
\hline $\begin{array}{l}\text { H6A, H6B, } \\
\text { H9A, H9B, } \\
\text { H12A, H12B }\end{array}$ & körte (Pyrus communis L. 'Conference') ág & Bekecs, 2006 \\
\hline H7A, H7B & $\begin{array}{l}\text { alma (Malus x domestica Borkh. 'Idared') levél, ág, } \\
\text { termés }\end{array}$ & \multirow{4}{*}{ Siófok, 2007} \\
\hline H8A, H8B & $\begin{array}{l}\text { alma (Malus x domestica Borkh. 'Johnny') levél, } \\
\text { ág, termés }\end{array}$ & \\
\hline H10A, H10B & $\begin{array}{l}\text { alma (Malus x domestica Borkh. 'Golden') levél, } \\
\text { ág, termés }\end{array}$ & \\
\hline H11 & birs (Cydonia oblonga Mill.) levél, ág & \\
\hline
\end{tabular}

\subsection{A FÁGIZOLÁTUMOK MORFOLÓGIAI JELLEMZÉSE 5.2.1 PLAKKMORFOLÓGIA}

A baktériumot tartalmazó agarlemezen kialakult plakk és az azt körülvevő sáv mérete alapján 22 magyar fágizolátum, négy amerikai fágtörzzsel összehasonlítva került jellemzésre (2. táblázat). A különböző bakteriofág izolátumok eltérő méretü, $0,5-7,1 \mathrm{~mm}$ átmérőjü plakkokat képeztek a tesztbaktériumot tartalmazó lágyagar rétegen. A magyar bakteriofág izolátumok közül a legkisebb plakkokat a H10A $(0,5-0,6 \mathrm{~mm})$ képzi, míg a tarfoltokat övező sávval együtt a H5K plakkjai a legkisebbek, s e tekintetben kevéssel maradnak el a ФEa116-os amerikai fágtól (18.a ábra). Izolátumaink közül a legnagyobb plakkokat a H6B, a H9B és a H7B képezte. Az amerikai bakteriofágok közül a $\Phi$ Ea100-as törzsnek vannak a legnagyobb átmérőjü plakkjai, 
melyek körül széles sáv is kialakul, azonban a H7B fág plakkja körül szélesebb sáv húzódik, ami annak nagyobb lítikus enzimaktivitására utal (18.b ábra).

5. táblázat A vizsgált fágok által képzett plakkok jellemzői. A megadott értéktartományok milliméterben $(\mathrm{mm})$ kifejezett minimum-maximum méreteket jelölnek 50 plakk vizsgálata alapján

\begin{tabular}{lll}
\hline Fág & Plakkátmérö $(\mathbf{m m})$ & $\begin{array}{l}\text { Plakk körüli sáv szélessége } \\
(\mathbf{m m})\end{array}$ \\
\hline H1A & $3,0-5,0$ & $1,0-2,0$ \\
H1B & $2,0-3,0$ & $0-1,0$ \\
H2A & $0,75-1,5$ & $0,1-0,3$ \\
H2B & $4,0-5,0$ & $1,0-1,1$ \\
H4A & $2,0-3,0$ & $0,5-1,0$ \\
H4B & $2,0-4,0$ & $1,5-2,0$ \\
H5K & $0,5-0,75$ & $0,2-0,4$ \\
H5A & $3,0-4,0$ & $0,8-2,0$ \\
H5B & $2,0-4,0$ & $0,8-2,0$ \\
H7A & $2,0-3,0$ & $1,0-2,0$ \\
H7B & $4,0-5,0$ & $1,5-5,0$ \\
H6A & $2,0-4,0$ & $0-1,0$ \\
H6B & $7,0-7,1$ & $1,5-2,0$ \\
H8A & $2,0-4,0$ & $0,8-1,0$ \\
H8B & $6,0-6,1$ & $1,8-2,0$ \\
H9A & $1,5-5,0$ & $1,0-2,0$ \\
H9B & $5,0-7,0$ & $1,0-2,0$ \\
H10A & $0,5-0,6$ & $1,0-1,2$ \\
H10B & $2,0-5,0$ & $1,0-2,0$ \\
H11 & $1,0-5,0$ & $1,0-1,5$ \\
H12A & $1,0-1,2$ & 0 \\
H12B & $3,0-5,0$ & $1,0-2,0$ \\
ФEa1h & $2,0-3,0$ & 0,5 \\
ФEa100 & $3,0-7,0$ & $0,5-3,0$ \\
ФEa104 & $2,0-3,0$ & 0 \\
ФEa116 & $1,0-2,0$ & 0 \\
\hline
\end{tabular}
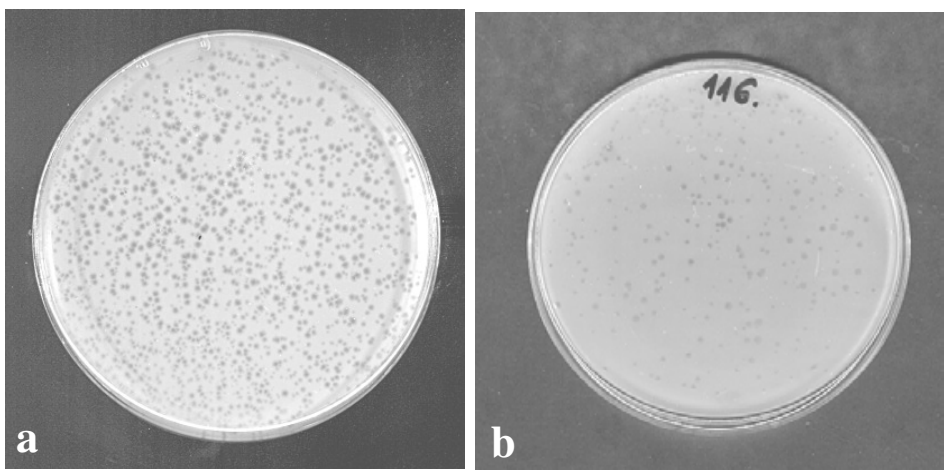

18.a ábra A H5K (a) magyar fágizolátum és a $\Phi E a 116$ (b) amerikai fágtörzs EaCFBP1430 tesztbaktériumot tartalmazó LBA táptalajon (10 cm átmérőjü Petri csészében) képzett plakkjai (Fotó: Schwarczinger I. és Kolozsváriné N.J.) 

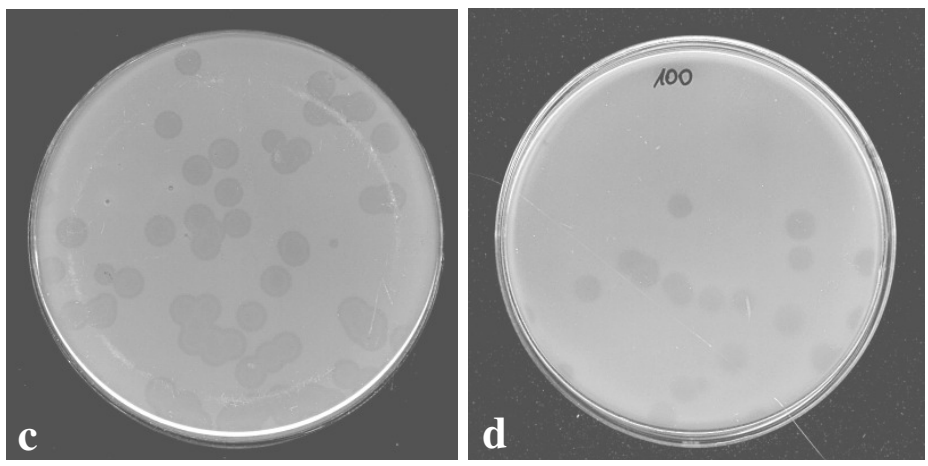

18.b ábra Tesztbaktériumot (EaCFBP1430) tartalmazó LBA táptalajon $(10 \mathrm{~cm}$ átméröjü Petri csészében) az egyik legnagyobb plakkokat képező hazai H7B (c), izolátum, illetve az amerikai $\Phi E a 100$ (d) fágtörzs jellemző alaki bélyegei (Fotó: Schwarczinger I. és Kolozsváriné N.J.)

\subsubsection{FÁGPARTIKULUM MORFOLÓGIA}

A fágizolátumokat morfológiai jellemzőik alapján Ackermann (2007) munkája nyomán különböző morfotípus csoportokba soroltuk. A vizsgált izolátumok közül 15 a Myoviridae család (A1 morfotípus) tagjaira jellemző ikozaéder alakú fejjel és hosszú, összehúzódó farki résszel rendelkezik, a másik 4 izolátumra kisebb, izometrikus fej és rövid, széles farki rész volt jellemző (19. ábra), mely alapján ez utóbbiak a Podoviridae családba (C1 morfotípus) lettek besorolva (6. táblázat). A magyar fágok közül a legkisebb a H11-es jelzésü fág, ami kisebb a szakirodalomból ismert német és az amerikai fágoknál (7. táblázat). A legnagyobb a H4A, amely méreteit tekintve meghaladja az előbb említett külföldi törzseket.
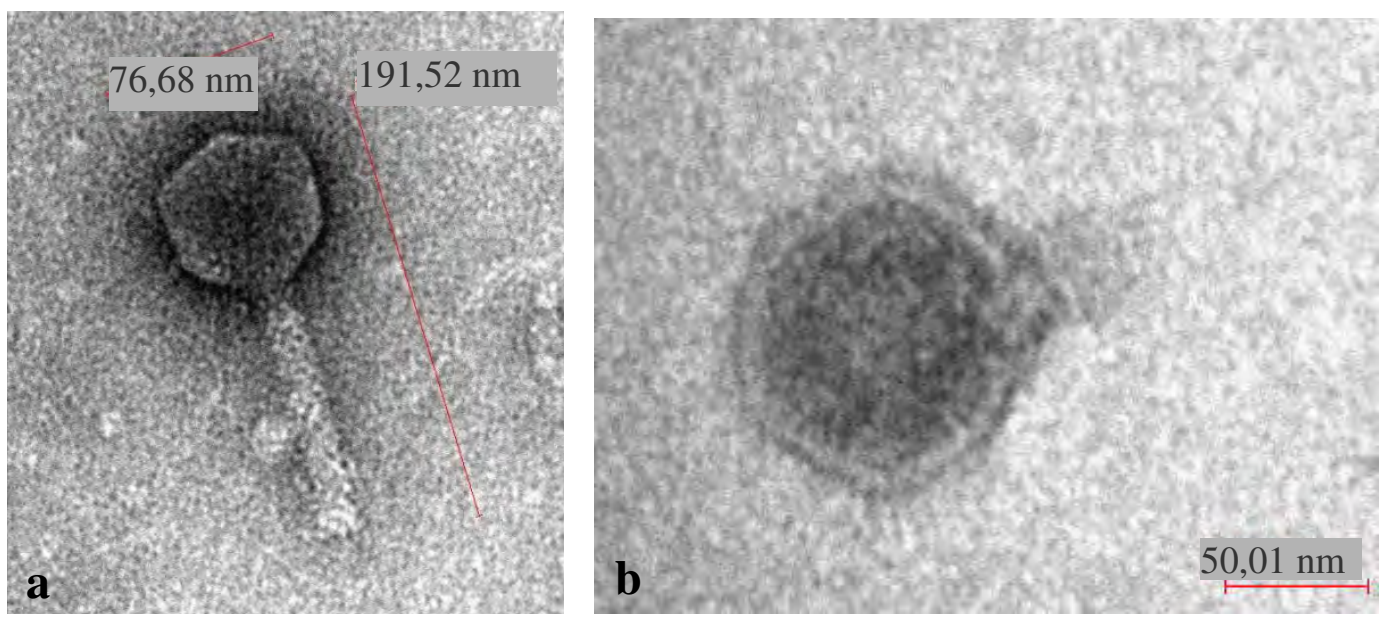

19. ábra A Myoviridae családba tartozó fágok (a) és a Podoviridae család fágjainak (b) jellemző partikulum felépítése. Az ábrák egy H5A fág (a) és egy H11 fágizolátum (b) TEM képét mutatják (Fotó: Szabó L. és Schwarczinger I.) 
6. táblázat Magyar E. amylovora fágok TEM vizsgálattal feltárt morfológiai jellemzői. A nanométerben $(\mathrm{nm})$ megadott értékek 50 mérés \pm SD kerekített átlagát mutatják.

\begin{tabular}{|c|c|c|c|c|}
\hline Besorolás & Fágizolátum & Fejátmérő (nm) & $\begin{array}{l}\text { Farokhossz } \\
(\mathrm{nm})\end{array}$ & $\begin{array}{l}\text { Farokszélesség } \\
(\mathbf{n m})\end{array}$ \\
\hline Myoviridae & H1A & $70 \pm 3$ & $117 \pm 4$ & $15 \pm 2$ \\
\hline \multirow{14}{*}{$\begin{array}{l}\text { (ikozaéder fej, } \\
\text { hosszú, } \\
\text { összehúzódó farki } \\
\text { rész) }\end{array}$} & H1B & $73 \pm 5$ & $94 \pm 17$ & $17 \pm 3$ \\
\hline & $\mathrm{H} 2 \mathrm{~A}$ & $69 \pm 7$ & $107 \pm 11$ & $13.7 \pm 1.0$ \\
\hline & $\mathrm{H} 2 \mathrm{~B}$ & $57 \pm 7$ & $60 \pm 39$ & $18 \pm 5$ \\
\hline & $\mathrm{H} 4 \mathrm{~A}$ & $78 \pm 5$ & $108 \pm 10$ & $17 \pm 2$ \\
\hline & $\mathrm{H} 4 \mathrm{~B}$ & $70 \pm 9$ & $98 \pm 18$ & $15 \pm 4$ \\
\hline & $\mathrm{H} 5 \mathrm{~A}$ & $72 \pm 3$ & $110 \pm 5$ & $13 \pm 1$ \\
\hline & H5B & $74 \pm 5$ & $104 \pm 9$ & $14 \pm 3$ \\
\hline & H6A & $64 \pm 3$ & $90 \pm 8$ & $10 \pm 0.2$ \\
\hline & H7A & $71 \pm 8$ & $99 \pm 7$ & $17 \pm 3$ \\
\hline & H7B & $77 \pm 5$ & $108 \pm 6$ & $17 \pm 1$ \\
\hline & H8A & $75 \pm 3$ & $113 \pm 4$ & $18 \pm 2$ \\
\hline & H9A & $69 \pm 5$ & $96 \pm 14$ & $17 \pm 3$ \\
\hline & $\mathrm{H} 10 \mathrm{~A}$ & $67 \pm 7$ & $103 \pm 18$ & $14 \pm 3$ \\
\hline & $\mathrm{H} 12 \mathrm{~B}$ & $72 \pm 4$ & $103 \pm 4$ & $15 \pm 1$ \\
\hline Podoviridae & H8B & $63 \pm 8$ & $8 \pm 4$ & $10 \pm 4$ \\
\hline \multirow{3}{*}{$\begin{array}{l}\text { (izometrikus fej és } \\
\text { rövid, széles farki } \\
\text { rész) }\end{array}$} & H9B & $61 \pm 7$ & $9 \pm 3$ & $12 \pm 3$ \\
\hline & H10B & $56 \pm 4$ & $9 \pm 1$ & $11 \pm 2$ \\
\hline & H11 & $55 \pm 2$ & $13 \pm 2$ & $8 \pm 1$ \\
\hline
\end{tabular}

7. táblázat Német és amerikai (Müller és mtsai. 2011a), valamint egy kanadai (Lehman és mtsai. 2009) E. amylovora fág morfológiai jellemzői nanométerben kifejezett, kerekített \pm SD értékekben megadva. A fent idézett munkákból átvett adatok.

\begin{tabular}{lllll}
\hline Besorolás & Fágizolátum $^{\mathrm{a}}$ & Fejátmérö $(\mathbf{n m})$ & $\begin{array}{l}\text { Farokhossz } \\
(\mathbf{n m})\end{array}$ & $\begin{array}{l}\text { Farokszélesség } \\
(\mathbf{n m})\end{array}$ \\
\hline Myoviridae & $\Phi E a 104^{\mathrm{A}}$ & $72 \pm 2$ & $114 \pm 3$ & $18 \pm 2$ \\
& $\Phi E a 116^{\mathrm{A}}$ & $73 \pm 2$ & $115 \pm 2$ & $20 \pm 1$ \\
& $\Phi E a J 08 \mathrm{C}^{\mathrm{N}}$ & $73 \pm 3$ & $116 \pm 5$ & $22 \pm 2$ \\
& $\Phi E a 21-4^{\mathrm{K}}$ & 60 & 90 & - \\
\hline Podoviridae & $\Phi E a 1 \mathrm{~h}^{\mathrm{A}}$ & $60+2$ & - & - \\
& $\Phi E a 100^{\mathrm{A}}$ & $61+2$ & - & - \\
& $\Phi E a J 08 \mathrm{~T}^{\mathrm{N}}$ & $60 \pm 1$ & - & - \\
\hline
\end{tabular}

${ }^{\mathrm{a}} \mathrm{A}$ : amerikai; N: német; K: kanadai 


\subsection{AZ IZOLÁLT FÁGOK MOLEKULÁRIS JELLEMZÉSE 5.3.1 PCR VIZSGÁLAT}

A PCR vizsgálatok eredményeként (lásd a M1.a-12.c mellékleteket) a vizsgált magyar fágokat 4 nagy csoportra osztottuk (8. táblázat). A zölddel jelölt csoport tagjai az amerikai ФEa116-hoz hasonlóan a termináz, peptidáz, és Mu-szerü profág proteint kódoló génre pozitívak. Ettől a következő három fág, a H5K, a H7B és a H12B csak egy-egy, illetve a H12B két DNS szakasszal tér el. A kék és árnyalataival jelzett fágok közül a H4B, H5A és H5B hasonlít nagyban a ФEa104-re, de még a legnagyobb hasonlóságot mutató H5B sem lehet azonos a $\Phi E a 104-g y e l$, mivel az erre a fágra tervezett specifikus primerrel a H5B esetében nem kaptunk jelet. A negyedik, piros árnyalatú csoport tagjai csupán egy-egy vizsgált génszakasz tekintetében térnek el a csoportban egymástól; a H9A törzs termináz gén pozitív, a H8B pedig az $E$. amylovora ams $\mathrm{F}$ génjének meghatározott szekvenciáját tartalmazza. Ezen kívül az összes többi tesztelt primer párra negatívnak bizonyultak.

8. táblázat Fágizolátumok PCR vizsgálatainak eredménye

\begin{tabular}{|c|c|c|c|c|c|c|c|c|c|c|c|c|c|c|c|c|c|c|c|c|c|c|c|c|c|}
\hline \multicolumn{26}{|c|}{ Fágok } \\
\hline Primer pár & 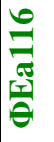 & 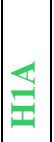 & $\theta$ & 离 & 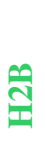 & $\underset{\Xi}{\stackrel{\Xi}{0}}$ & $\stackrel{\theta}{\theta}$ & $\exists$ & 崩 & $\frac{1}{10}$ & 草 & $\underline{\Xi}$ & 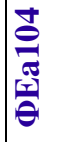 & $\frac{m}{10}$ & 里 & $\begin{array}{l}\mathbb{2} \\
10 \\
\mathbb{Z}\end{array}$ & \pm & $\frac{0}{\mathscr{E}}$ & $\frac{m}{2}$ & $\underset{\mathbb{Z}}{\infty}$ & $\mathbb{N}$ & $\stackrel{\infty}{\mathscr{\infty}}$ & 苂 & 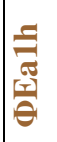 & $\begin{array}{l}\frac{8}{6} \\
\frac{\pi}{6} \\
\frac{r}{\gamma} \\
\theta\end{array}$ \\
\hline Dpo-1/2c & nv & - & - & - & - & - & - & = & - & - & + & + & nv & + & + & + & + & + & + & - & + & - & - & inv & nv \\
\hline Hol-F/R & - & $=$ & - & - & $=$ & - & - & - & - & - & - & $=$ & + & + & + & + & + & + & + & + & - & - & - & + & + \\
\hline Lys-F/R & - & $=$ & - & - & - & - & - & - & - & - & - & $=$ & + & + & + & + & + & + & + & + & - & - & - & + & + \\
\hline Term-F/R & + & + & + & + & + & + & + & + & + & + & + & + & + & nv & nv & $\mathrm{nv}$ & $\mathrm{nv}$ & + & + & + & + & - & + & - & $=$ \\
\hline Pep-F/R & + & + & + & + & + & + & + & + & + & - & + & + & + & nv & nv & $\mathrm{nv}$ & + & $\mathrm{nV}$ & + & + & + & - & $=$ & - & $=$ \\
\hline $\mathrm{Mu}-\mathrm{F} / \mathrm{R}$ & + & + & + & + & + & + & + & + & + & + & + & + & + & + & - & $=$ & + & + & + & + & + & - & $=$ & $=$ & - \\
\hline $\mathrm{PEa} 1 \mathrm{~A} / \mathrm{B}$ & nv & $=$ & - & $=$ & - & - & - & - & - & - & - & + & nv & + & + & + & + & + & + & $=$ & + & - & $=$ & + & $\mathrm{nVV}$ \\
\hline Ea100F/R & + & $=$ & $=$ & - & - & - & $=$ & - & $=$ & - & $=$ & $=$ & + & + & + & $=$ & $=$ & $=$ & - & $=$ & $=$ & - & - & + & + \\
\hline Ea104F/R & - & $=$ & $=$ & $=$ & $=$ & - & $=$ & $=$ & $=$ & - & $=$ & $=$ & + & $=$ & - & $=$ & $=$ & $=$ & $=$ & $=$ & $=$ & - & $=$ & nv & $\mathrm{nv}$ \\
\hline 1hcapF/R & nv & $=$ & $=$ & $=$ & $=$ & - & $=$ & $=$ & $=$ & - & $=$ & $=$ & + & + & + & $=$ & $=$ & - & $=$ & $=$ & $=$ & - & $=$ & + & $\mathrm{nv}$ \\
\hline H2capF/R & nv & $=$ & $=$ & $=$ & - & $=$ & $=$ & $=$ & $=$ & - & $=$ & $=$ & - & $=$ & - & $=$ & $=$ & $=$ & - & $=$ & $=$ & - & $=$ & $=$ & $\mathrm{nv}$ \\
\hline EaFF/R & nv & + & + & + & + & + & + & + & + & + & + & + & nv & + & + & + & + & + & + & + & + & + & $=$ & + & $\mathrm{nv}$ \\
\hline phiEaH2-F/R & - & - & - & - & - & - & - & - & - & - & - & - & - & - & - & - & - & - & - & - & - & - & - & - & - \\
\hline
\end{tabular}

Az azonos színek az egy csoportba sorolt fágokat jelölik, a színárnyalatok a föcsoportokon belüli eltérésre utalnak. nv : nem vizsgált; + : pozitív; - : negatív

Az ismert genomú $\Phi E a H 2$ magyar fágtörzs amsF-szerü szakaszára tervezett primerpár nem adott csíkot a vizsgált fágizolátumoknál és törzseknél, ugyanakkor egy kivételével (H9A) 
valamennyi tesztelt hazai fágizolátum pozitívnak bizonyult az E. amylovora amsF génjének az EaFF/R indító szekvenciák által meghatározott szakaszára.

\subsubsection{SZEKVENCIA-ANALÍZIS}

Jelenleg, az eddig vizsgált DNS szekvenciák közül, hét dpo génre pozitív hazai fágizolátumunk genomjának depolimerázt kódoló szakaszáról és a leghatékonyabb fágizolátumok közül a H2A peptidázt kódoló szakaszáról, valamint a H2A és a H5K Mu-szerü profág proteint és terminázt kódoló régióiról rendelkezünk adatokkal. A fágizolátumok (H4A, H4B, H5A, H5B, H6A, H7A, H9B) depolimeráz génjének bázis sorrendje 98-99\%-ban egyezést mutat a ФEa1h (Müller és mtsai. 2011b) depolimeráz génjének a 43070-43693 szakaszig tartó részének a bázis sorrendjével (lásd az M13. mellékletet). A H2A peptidázt kódoló régiója 99\%ban megegyezik a vB_EamM-M7 E. amylovora fág (Born és mtsai. 2011) genomjának a 1369414194 nukleotid közötti sorrendjével (M14.). A vizsgált fágszekvenciában a 14092 helyen "T” helyett "G" áll a genom nem transzlálódó régiójában. A H2A és a H5K izolátumok terminázt meghatározó szakasza 99\%-ban megegyezik a vB_EamM-M7 fágtörzs meghatározott kódoló régiójával (M15-16.). Mu-szerü proteint kódoló szakaszaik szintén a vB_EamM-M7 fág adott DNS szakaszaival [20850-től 21525-ig (H2A), 20853-tól 21556-ig (H5K)] mutatnak nagyfokú, 99\%-os hasonlóságot; az eltérések fenotipikus változást nem okoznak (M17-18.).

\subsection{GAZDAKÖRVIZSGÁLAT}

A kísérletek eredményéből (9-11. táblázat) az derült ki, hogy a magyar fágok a vizsgálatban szereplő amerikai fágtörzsekhez képest szélesebb gazdakörrel rendelkeznek. A tesztelt fágok közül 6 magyar (H1B, H2A, H2B, H4A, H7A, H7B) fág bizonyult Erwiniaspecifikusnak, mivel ezek, az E. tasmaniensis kivételével lizálták az összes vizsgált Erwinia izolátumot és törzset, míg más tesztelt, az Erwinia-val nem közeli rokon patogén baktériumra két kivétellel nem voltak fogékonyak. A H2B és a H7B ugyanis lizálta a Pseudomonas syringae pv. syringae H9 baktériumtörzset. A gazdakör vizsgálatokat kiterjesztettük az E. amylovora-val közeli rokon, de nem patogén baktériumokra is azzal a céllal, hogy a bakteriofágok felszaporításához és a védendő növény felületére való kijuttatáshoz megtaláljuk a legmegfelelőbb organizmust. A kísérletben szereplő, növénykárosító hatással nem rendelkező baktériumok közül a Pantoea agglomerans MB96 volt a legfogékonyabb a vizsgált fágokkal szemben: a H4B kivételével valamennyi fág tiszta plakkokat képzett ezen a baktériumtörzsön. Gazdakör vizsgálatuk alapján a hazai fágok közül a H1B, H2A, H2B, H4A, H7A, H7B voltak a 
leghatékonyabbak, míg az amerikai fágok közül a ФEa116-os lizálta a legtöbb tesztelt baktériumtörzset.

A magyar E. amylovora izolátumok mindegyike fogékony volt a fágizolátumokkal szemben függetlenül a fágok származásától. A nem Magyarországról származó E. amylovora törzsek közül a legfogékonyabbnak az EaDS05 jelzésű német törzs bizonyult. Az egyéb ervinia fajok közül az E. billingae Eb661 ${ }^{\mathrm{T}}$ volt a legfogékonyabb. Az E. tasmaniensis Et1/99 baktériumtörzset csupán az amerikai $\Phi$ Ea1h fágtörzs lizálta.

9. táblázat Magyarországi E. amylovora izolátumok fágizolátumokkal szembeni fogékonysága

\begin{tabular}{|c|c|c|c|c|c|c|c|c|c|c|c|c|c|c|c|c|c|c|c|c|}
\hline \multicolumn{21}{|c|}{ Fágok } \\
\hline $\begin{array}{l}\text { E. amylovora } \\
\text { (Ea) izolátum }\end{array}$ & $\Xi$ & $\underline{\Xi}$ & $\underset{\mathbb{Z}}{\mathbb{Z}}$ & 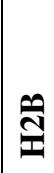 & $\underset{\Xi}{\Xi}$ & $\stackrel{\ominus}{ \pm}$ & $\underset{1}{2}$ & 苂 & $\underset{\mathbf{\sigma}}{\mathbb{1}}$ & $\mathbb{I}$ & $\underset{1}{\underline{E}}$ & $\underset{\infty}{\infty}$ & 产 & 荁 & $\Xi$ & 气ิ & 可 & 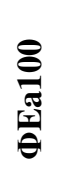 & 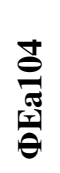 & 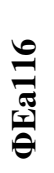 \\
\hline Ea1 & ++ & ++ & ++ & ++ & ++ & ++ & ++ & ++ & ++ & ++ & ++ & ++ & ++ & ++ & ++ & ++ & ++ & ++ & ++ & ++ \\
\hline $\mathrm{Ea} 2$ & ++ & ++ & ++ & ++ & ++ & ++ & ++ & ++ & ++ & ++ & ++ & ++ & ++ & ++ & ++ & ++ & ++ & ++ & ++ & ++ \\
\hline $\mathrm{Ea} 3$ & ++ & ++ & ++ & ++ & ++ & ++ & ++ & ++ & ++ & ++ & ++ & ++ & ++ & ++ & ++ & ++ & ++ & ++ & ++ & ++ \\
\hline Ea4 & ++ & ++ & ++ & ++ & ++ & ++ & ++ & ++ & ++ & ++ & ++ & ++ & ++ & ++ & ++ & ++ & ++ & ++ & ++ & ++ \\
\hline Ea5 & ++ & ++ & ++ & ++ & ++ & ++ & ++ & ++ & ++ & ++ & ++ & ++ & ++ & ++ & ++ & ++ & ++ & ++ & ++ & ++ \\
\hline $\mathrm{Ea} 6$ & ++ & ++ & ++ & ++ & ++ & ++ & ++ & ++ & ++ & ++ & ++ & ++ & ++ & ++ & ++ & ++ & ++ & ++ & ++ & ++ \\
\hline $\mathrm{Ea} 7$ & ++ & ++ & ++ & ++ & ++ & ++ & ++ & ++ & ++ & ++ & ++ & ++ & ++ & ++ & ++ & ++ & ++ & ++ & ++ & ++ \\
\hline $\mathrm{Ea} 8$ & ++ & ++ & ++ & ++ & ++ & ++ & ++ & ++ & ++ & ++ & ++ & ++ & ++ & ++ & ++ & ++ & ++ & ++ & ++ & ++ \\
\hline Ea10 & ++ & ++ & ++ & ++ & ++ & ++ & ++ & ++ & ++ & ++ & ++ & ++ & ++ & ++ & ++ & ++ & ++ & ++ & ++ & ++ \\
\hline Ea11 & ++ & ++ & ++ & ++ & ++ & ++ & ++ & ++ & ++ & ++ & ++ & ++ & ++ & ++ & ++ & ++ & ++ & ++ & ++ & ++ \\
\hline Ea12 & ++ & ++ & ++ & ++ & ++ & ++ & ++ & ++ & ++ & ++ & ++ & ++ & ++ & ++ & ++ & ++ & ++ & ++ & ++ & ++ \\
\hline Ea13 & ++ & ++ & ++ & ++ & ++ & ++ & ++ & ++ & ++ & ++ & ++ & ++ & ++ & ++ & ++ & ++ & ++ & ++ & ++ & ++ \\
\hline Ea14 & ++ & ++ & ++ & ++ & ++ & ++ & ++ & ++ & ++ & ++ & ++ & ++ & ++ & ++ & ++ & ++ & ++ & ++ & ++ & ++ \\
\hline Ea15 & ++ & ++ & ++ & ++ & ++ & ++ & ++ & ++ & ++ & ++ & ++ & ++ & ++ & ++ & ++ & ++ & ++ & ++ & ++ & ++ \\
\hline Ea17 & ++ & ++ & ++ & ++ & ++ & ++ & ++ & ++ & ++ & ++ & ++ & ++ & ++ & ++ & ++ & ++ & ++ & ++ & ++ & ++ \\
\hline Ea18 & ++ & ++ & ++ & ++ & ++ & ++ & ++ & ++ & ++ & ++ & ++ & ++ & ++ & ++ & ++ & ++ & ++ & ++ & ++ & ++ \\
\hline Ea19 & ++ & ++ & ++ & ++ & ++ & ++ & ++ & ++ & ++ & ++ & ++ & ++ & ++ & ++ & ++ & ++ & ++ & ++ & ++ & ++ \\
\hline $\mathrm{Ea} 20$ & ++ & ++ & ++ & ++ & ++ & ++ & ++ & ++ & ++ & ++ & ++ & ++ & ++ & ++ & ++ & ++ & ++ & ++ & ++ & ++ \\
\hline
\end{tabular}


Fágok

\begin{tabular}{|c|c|c|c|c|c|c|c|c|c|c|c|c|c|c|c|c|c|c|c|c|}
\hline $\begin{array}{l}\text { E. amylovora } \\
\text { (Ea) izolátum }\end{array}$ & $\Xi$ & 是 & $\underset{\mathbb{Z}}{\mathbb{Z}}$ & 气ै & $\underset{\Xi}{\mathbb{I}}$ & 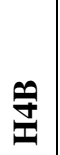 & $\stackrel{\mathbb{\Omega}}{\stackrel{\pi}{\pi}}$ & 党 & 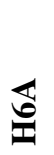 & $\mathbb{x}$ & $\stackrel{0}{\mathbf{E}}$ & $\underset{\infty}{\mathbb{I}}$ & $\hat{\widehat{\Xi}}$ & 目 & $\Xi$ & 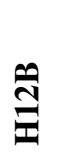 & $\underset{\substack{\sigma \\
\theta}}{\vec{\sigma}}$ & 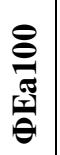 & 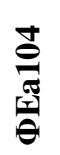 & 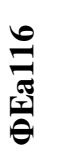 \\
\hline $\mathrm{Ea} 21$ & ++ & ++ & ++ & ++ & ++ & ++ & ++ & ++ & ++ & ++ & ++ & ++ & ++ & ++ & ++ & ++ & ++ & ++ & ++ & ++ \\
\hline $\mathrm{Ea} 22$ & ++ & ++ & ++ & ++ & ++ & ++ & ++ & ++ & ++ & ++ & ++ & ++ & ++ & ++ & ++ & ++ & ++ & ++ & ++ & ++ \\
\hline $\mathrm{Ea} 24$ & ++ & ++ & ++ & ++ & ++ & ++ & ++ & ++ & ++ & ++ & ++ & ++ & ++ & ++ & ++ & ++ & ++ & ++ & ++ & ++ \\
\hline Ea25 & ++ & ++ & ++ & ++ & ++ & ++ & ++ & ++ & ++ & ++ & ++ & ++ & ++ & ++ & ++ & ++ & ++ & ++ & ++ & ++ \\
\hline $\mathrm{Ea} 26$ & ++ & ++ & ++ & ++ & ++ & ++ & ++ & ++ & ++ & ++ & ++ & ++ & ++ & ++ & ++ & ++ & ++ & ++ & ++ & ++ \\
\hline $\mathrm{Ea} 27$ & ++ & ++ & ++ & ++ & ++ & ++ & ++ & ++ & ++ & ++ & ++ & ++ & ++ & ++ & ++ & ++ & ++ & ++ & ++ & ++ \\
\hline $\mathrm{Ea} 28$ & ++ & ++ & ++ & ++ & ++ & ++ & ++ & ++ & ++ & ++ & ++ & ++ & ++ & ++ & ++ & ++ & ++ & ++ & ++ & ++ \\
\hline Ea29 & ++ & ++ & ++ & ++ & ++ & ++ & ++ & ++ & ++ & ++ & ++ & ++ & ++ & ++ & ++ & ++ & ++ & ++ & ++ & ++ \\
\hline Ea30 & ++ & ++ & ++ & ++ & ++ & ++ & ++ & ++ & ++ & ++ & ++ & ++ & ++ & ++ & ++ & ++ & ++ & ++ & ++ & ++ \\
\hline Ea31 & ++ & ++ & ++ & ++ & ++ & ++ & ++ & ++ & ++ & ++ & ++ & ++ & ++ & ++ & ++ & ++ & ++ & ++ & ++ & ++ \\
\hline
\end{tabular}

++ : tiszta plakk

10. táblázat Különböző E. amylovora törzsek és egyéb Erwinia fajok fágizolátumokkal szembeni fogékonysága

\section{Fágok}

Erwinia törzs

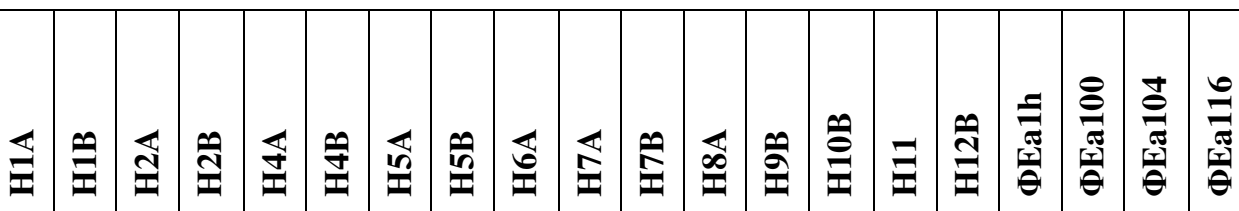

\begin{tabular}{|l|c|c|c|c|c|c|c|c|c|c|c|c|c|c|c|c|c|c|c|c|} 
Ea1/79del100 & - & ++ & ++ & ++ & ++ & - & - & - & - & + & + & - & + & - & - & - & - & - & - & ++ \\
\hline Ea1/79Sm & + & ++ & ++ & ++ & ++ & + & ++ & ++ & ++ & ++ & ++ & ++ & ++ & ++ & ++ & ++ & + & + & ++ & + \\
\hline EaDS02 & - & ++ & ++ & ++ & + & - & - & - & - & ++ & ++ & ++ & - & - & - & - & - & - & - & ++ \\
\hline EaDS05 & + & ++ & ++ & ++ & ++ & + & ++ & ++ & ++ & ++ & ++ & ++ & ++ & ++ & ++ & ++ & + & + & ++ & + \\
\hline EaRW & + & ++ & ++ & ++ & ++ & + & ++ & ++ & ++ & ++ & ++ & ++ & ++ & ++ & ++ & ++ & + & + & ++ & + \\
\hline EaOR1/7 & - & ++ & ++ & ++ & ++ & + & - & - & - & ++ & ++ & + & ++ & - & - & - & - & - & + & ++ \\
\hline Ea63/05 & + & ++ & ++ & ++ & ++ & + & + & ++ & ++ & ++ & ++ & ++ & ++ & ++ & ++ & ++ & + & + & ++ & + \\
\hline EaCFBP1430 & + & ++ & ++ & + & ++ & + & + & + & + & ++ & ++ & + & ++ & + & + & + & + & + & + & ++ \\
\hline $\begin{array}{l}\text { E. billingiae } \\
\text { Eb661 }\end{array}$ & - & ++ & ++ & ++ & ++ & ++ & ++ & ++ & ++ & ++ & ++ & ++ & ++ & ++ & ++ & ++ & + & + & - & + \\
\hline E. persicina & - & + & + & + & + & - & - & - & - & ++ & ++ & - & - & - & - & - & - & - & - & - \\
\hline
\end{tabular}




\begin{tabular}{|c|c|c|c|c|c|c|c|c|c|c|c|c|c|c|c|c|c|c|c|c|}
\hline \multicolumn{21}{|c|}{ Fágok } \\
\hline Erwinia törzs & $\Xi$ & 当 & 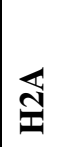 & తิ & 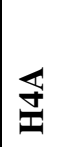 & 章 & $\stackrel{\mathbb{3}}{\pi}$ & 色 & $\underset{\Xi}{\tilde{\Xi}}$ & $\mathbb{s}$ & $\stackrel{0}{\underline{\Xi}}$ & 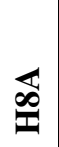 & $\hat{\overline{1}}$ & 色 & $\Xi$ & 突 & 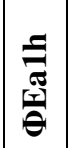 & 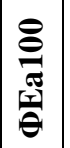 & 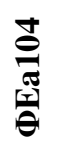 & 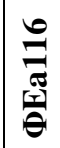 \\
\hline $\begin{array}{l}\text { E. rhapontici } \\
\text { CFBP 3618T }\end{array}$ & - & + & + & + & + & - & - & - & - & + & + & - & - & + & - & - & - & - & + & + \\
\hline $\begin{array}{l}\text { E. tasmaniensis } \\
\text { Et1/99 }\end{array}$ & - & - & - & - & - & - & - & - & - & - & - & - & - & - & - & - & + & - & - & - \\
\hline
\end{tabular}

++ : tiszta plakk; + : homályos plakk; - : nincs plakk

A Pantoea fajok szintén fogékonyak voltak a fágok többségére (11. táblázat), kivéve a Pantoea agglomerans C9-1, amit a H4B, ФEa1h, ФEa100 és a ФEa116 nem volt képes lizálni. A vizsgált egyéb kórokozó baktériumok közül a Pantoea citrea CCM 4319-n és a két Pantoea stewartii ssp. stewarti törzsön kívül a Pseudomonas syringae pv. syringae H9-es törzs volt még fogékony a fágokra. Közülük a legfogékonyabbnak a Pantoea stewartii ssp. stewartii DC283 törzs bizonyult.

11. táblázat Különböző tesztbaktériumok fágokkal szembeni fogékonysága

\begin{tabular}{|c|c|c|c|c|c|c|c|c|c|c|c|c|c|c|c|c|c|c|c|c|}
\hline \multicolumn{21}{|c|}{ Fágok } \\
\hline Baktériumtörzsek & $\Xi$ & $\underline{\Xi}$ & $\underset{\mathfrak{I}}{\mathfrak{I}}$ & בิ & $\underset{ \pm}{\Xi}$ & $\underset{\nabla}{ \pm}$ & $\underset{\mathbb{Z}}{\mathbb{Z}}$ & $\stackrel{\infty}{3}$ & $\underset{\mathbb{\sigma}}{\mathbb{Z}}$ & $\mathbb{I}$ & $\underline{\underline{Z}}$ & $\underset{\infty}{\mathscr{Z}}$ & 产 & 皇 & $\Xi$ & 臺 & 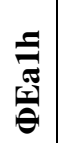 & $\underset{\substack{\sigma \\
\frac{\sigma}{6}}}{\frac{\sigma}{6}}$ & 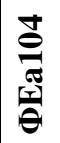 & 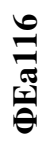 \\
\hline $\begin{array}{l}\text { Pantoea } \\
\text { agglomerans NB2 }\end{array}$ & ++ & ++ & ++ & ++ & ++ & ++ & ++ & + & ++ & ++ & + & + & ++ & ++ & + & + & ++ & ++ & ++ & ++ \\
\hline $\begin{array}{l}\text { Pantoea } \\
\text { agglomerans MB96 }\end{array}$ & ++ & ++ & ++ & ++ & ++ & - & ++ & ++ & ++ & ++ & ++ & ++ & ++ & ++ & ++ & ++ & ++ & ++ & ++ & ++ \\
\hline $\begin{array}{l}\text { Pantoea } \\
\text { agglomerans JCM } \\
1236\end{array}$ & ++ & ++ & ++ & ++ & ++ & ++ & ++ & ++ & ++ & ++ & + & + & + & + & + & + & ++ & ++ & + & + \\
\hline $\begin{array}{l}\text { Pantoea } \\
\text { agglomerans } \\
\text { hu } 82245\end{array}$ & ++ & ++ & ++ & + & ++ & ++ & ++ & ++ & ++ & ++ & ++ & ++ & ++ & ++ & + & + & ++ & ++ & ++ & ++ \\
\hline $\begin{array}{l}\text { Pantoea } \\
\text { agglomerans } \\
\text { hu82647 }\end{array}$ & - & + & + & + & + & - & - & + & + & + & + & ++ & + & + & + & ++ & ++ & ++ & ++ & ++ \\
\hline $\begin{array}{l}\text { Pantoea } \\
\text { agglomerans C9-1 }\end{array}$ & + & + & + & + & + & - & + & + & + & + & + & + & + & ++ & ++ & ++ & - & - & + & - \\
\hline $\begin{array}{l}\text { Pantoea citrea CCM } \\
4319\end{array}$ & ++ & ++ & ++ & + & ++ & ++ & ++ & ++ & ++ & ++ & + & ++ & ++ & ++ & + & + & ++ & ++ & ++ & ++ \\
\hline
\end{tabular}


Fágok

\begin{tabular}{|c|c|c|c|c|c|c|c|c|c|c|c|c|c|c|c|c|c|c|c|c|}
\hline Baktériumtörzsek & $\Xi$ & $\underline{\underline{Z}}$ & $\overleftrightarrow{\Xi}$ & 气ิ & $\underset{\mathbb{I}}{\mathbb{I}}$ & $\underset{\nabla}{\mathscr{\theta}}$ & $\stackrel{\mathbb{2}}{\pi}$ & $\stackrel{0}{n}$ & 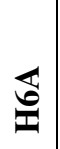 & $\mathbb{E}$ & $\underline{\underline{I}}$ & $\underset{\infty}{\mathbb{Z}}$ & 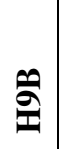 & 皇 & $\Xi$ & $\underset{\widetilde{\Xi}}{\stackrel{\oplus}{\Xi}}$ & 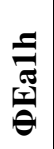 & $\underset{\substack{0 \\
\frac{0}{0}}}{\frac{\pi}{\theta}}$ & 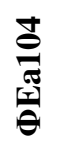 & 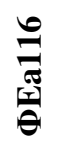 \\
\hline $\begin{array}{l}\text { Pantoea stewartii } \\
\text { subsp. stewarti } \\
\text { DC } 283\end{array}$ & ++ & ++ & ++ & ++ & ++ & ++ & ++ & ++ & ++ & ++ & ++ & ++ & ++ & ++ & ++ & + & + & + & + & + \\
\hline $\begin{array}{l}\text { Pantoea stewartii } \\
\text { subsp. stewartii } \\
\text { SW2 }\end{array}$ & - & ++ & ++ & ++ & + & + & - & - & + & ++ & ++ & + & ++ & + & + & + & + & ++ & ++ & ++ \\
\hline $\begin{array}{l}\text { Agrobacterium } \\
\text { tumefaciens C58 }\end{array}$ & - & - & - & - & - & - & - & - & - & - & - & - & - & - & - & - & - & - & - & - \\
\hline $\begin{array}{l}\text { Agrobacterium vitis } \\
\text { F2/5 }\end{array}$ & - & - & - & - & - & - & - & - & - & - & - & - & - & - & - & - & - & - & - & - \\
\hline $\begin{array}{l}\text { Escherichia coli } \\
\text { DH5 } \alpha\end{array}$ & - & - & - & - & - & - & - & - & - & - & - & - & - & - & - & - & - & - & - & - \\
\hline $\begin{array}{l}\text { Xanthomonas } \\
\text { campestris pv. } \\
\text { zinniae }\end{array}$ & - & - & - & - & - & - & - & - & - & - & - & - & - & - & - & - & - & - & - & - \\
\hline $\begin{array}{l}\text { Pseudomonas } \\
\text { cichorii }\end{array}$ & - & - & - & - & - & - & - & - & - & - & - & - & - & - & - & - & - & - & - & - \\
\hline $\begin{array}{l}\text { Pseudomonas } \\
\text { syringae } \mathrm{pv} . \\
\text { syringae } \mathrm{H} 9\end{array}$ & - & - & - & ++ & - & - & ++ & - & + & - & + & + & + & + & + & + & + & ++ & ++ & ++ \\
\hline $\begin{array}{l}\text { Pectobacterium } \\
\text { carotovorum subsp. } \\
\text { Carotovorum } 19111\end{array}$ & - & - & - & - & - & - & - & - & - & - & - & - & - & - & - & - & - & - & - & - \\
\hline $\begin{array}{l}\text { Pectobacterium } \\
\text { carotovorum subsp. } \\
\text { atroseptica D2 }\end{array}$ & - & - & - & - & - & - & - & - & - & - & - & - & - & - & - & - & - & - & - & - \\
\hline
\end{tabular}

++ : tiszta plakk; + : homályos plakk; - : nincs plakk

\subsection{FÁGOK ÉS FÁGKOMBINÁCIÓK HATÁSÁNAK VIZSGÁLATA AZ ERWINIA AMYLOVORA BAKTÉRIUMRA}

\subsubsection{FÁG HATÁSVIZSGÁLAT FOLYADÉKKULTÚRÁBAN}

Fágizolátumainknak a tüzelhalás kórokozójának szaporodását gátló hatását először LB tápoldatban vizsgáltuk. A fágoknak a tesztbaktérium szuszpenziójával történő 22 órás együtt rázatását követően a folyékony kultúrák spektrofotométerrel meghatározott fénytörése $\left(\mathrm{OD}_{600}\right)$ alapján értékelve a kísérletet azt tapasztaltuk, hogy a magyar fágizolátumok a H1A, H4A és a H6B kivételével szignifikánsan lecsökkentették a baktérium-koncentrációt a fágmentes, pozitív 
kontrollhoz képest. Az amerikai törzsek közül csak a ФEa100 hatása tért el szignifikánsan az erviniás kontrollétól. A leghatékonyabbaknak a H2A, a $\mathrm{H} 5 \mathrm{~K}$ és a H7B fágizolátumok bizonyultak. (20. ábra). A H5K és a H7B szignifikánsan hatékonyabb volt a H6B izolátumhoz viszonyítva is, ugyanakkor a többi esetben az egyes kezelések baktériumszám-csökkentő hatása között nem volt megállapítható szignifikáns különbség.

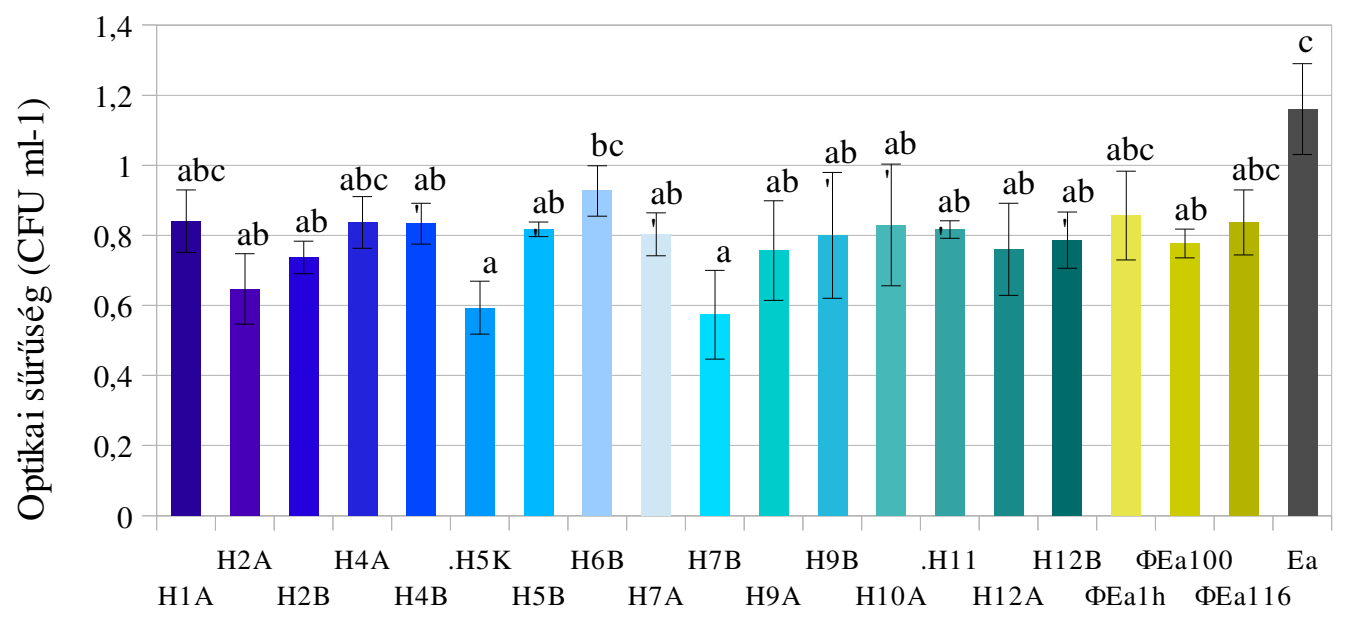

Kezelés

20. ábra Fágok hatása az $E$ amylovora szaporodására folyadékkultúrában. Az első 16 oszlop a hazai fágizolátumok, a következő 3 az amerikai fágtörzsek hatását mutatja be. Az utolsó (Ea) oszlop az erviniás kontroll. Az ábrázolt értékek három ismétlés átlagát és szórását jelölik. A különböző betük az egyes kezelések közötti szignifikáns különbséget jelentik $(\mathrm{P}=0,01$ szinten, kivéve ab', mely c -től csupán $\mathrm{P}=$ 0,05 szinten tér el).

Annak tisztázására, hogy a fágizolátumaink önmagukban vagy együttesen alkalmazva fejtenek-e ki nagyobb gátló hatást a baktérium szaporodására, az előző kísérletben leghatékonyabban szereplő három fágtörzs (H2A, H5K és H7B) kombinációinak a hatékonyságát is vizsgáltuk. A kezelések közül a legjobb eredményt a fágok hármas kombinációja adta, ez esetben kaptuk a legalacsonyabb $\left(0,36 \mathrm{CFU} \mathrm{ml}^{-1}\right) \mathrm{OD}_{600}$ értéket a kezeletlen kontrollhoz $\left(0,62 \mathrm{CFU} \mathrm{ml}^{-1}\right)$ képest, mindazonáltal az egyes kezelések között csak a H7B és a H5K+H7B, valamint a H7B és a H2A+H5K+H7B esetén volt szignifikáns a különbség (21. ábra). 


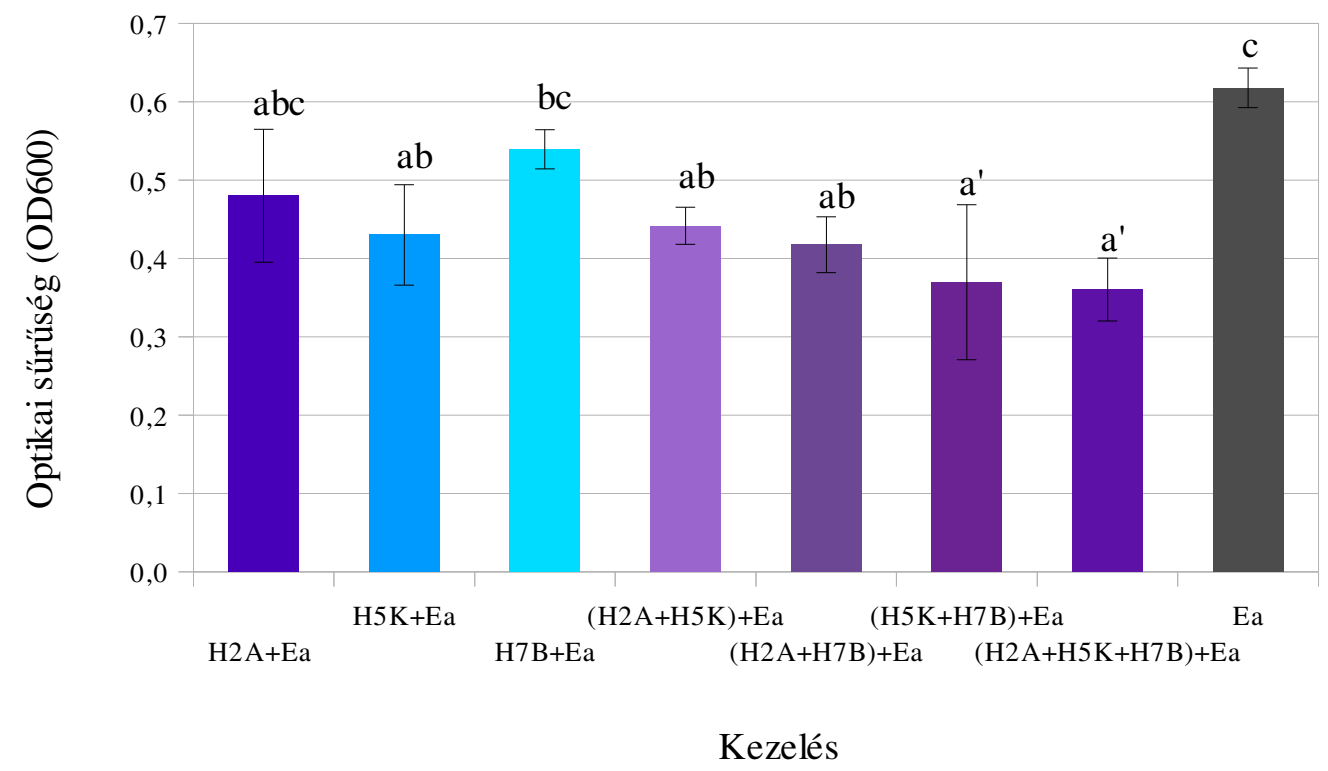

21. ábra Fágok és fágkombinációk az E. amylovora szaporodására gyakorolt hatásának összehasonlítása folyadékkultúrában. Az első 7 oszlop hazai fágizolátumokat és azok kombinációit jelöli, az utolsó (Ea) az erviniás pozitív kontrollt. Az ábrázolt értékek három ismétlés átlagát és szórását jelölik. A különböző betük az egyes kezelések közötti szignifikáns különbséget jelentik ( $\mathrm{P}=0,05$ szinten, kivéve a', mely c-töl $\mathrm{P}=0,01$ szinten tér el).

\subsubsection{FÁG HATÁSVIZSGÁLAT ALMA-ÉS BIRSVIRÁGON}

\subsubsection{Baktériumsejt-számlálás}

A vizsgálat célja annak tisztázása volt, hogy a virágok fággal történő közvetlen kezelése milyen mértékben tudja csökkenteni a virágokról visszaizolált baktériumok számát, illetve, hogy a bakteriofágok hatása függ-e a növény E. amylovora-val szembeni fogékonyságától.

A 2011. évi vizsgálatban mind a négy almafajta és a birs esetén a fágos kezelés csökkentette a visszaizolált baktériumok számát (22. ábra). A 'Golden delicious Reinders' almafajta virágainak a H5K fággal történő kezelését leszámítva valamennyi tesztnövényen mindegyik fágkezelés szignifikánsan hatékonyabb volt az erviniás kontrollhoz képest. A 'Gala Schniga', a 'Pinova' és a 'Berecki' esetében a fágkombináció eredményezte a legjobb hatást. A fágkoktél az E. amylovora-val szemben legeredményesebb a 'Gala Schniga' fajtán volt, ahol a kezelés 95\%-kal, szignifikánsan csökkentette a virágokról visszaizolált baktériumszámot a kezeletlen kontrollhoz viszonyítva. Az 'Idared' fajtán belül a H2A fágkezelés, a 'Pinova' fajtánál a H7B fágkezelés hatása szignifikánsan eltért a többi kezelés hatékonyságától, míg a 'Golden delicious Reinders' esetében a H5K és a H7B tért el egymástól szignifikánsan. A többi esetben az egyes fágkezelések hatékonysága között szignifikáns különbség nem volt megállapítható (12. 
táblázat). Valamennyi vizes kontroll negatívnak bizonyult, ami alapján természetes $E$. amylovora fertőzés kizárható volt.

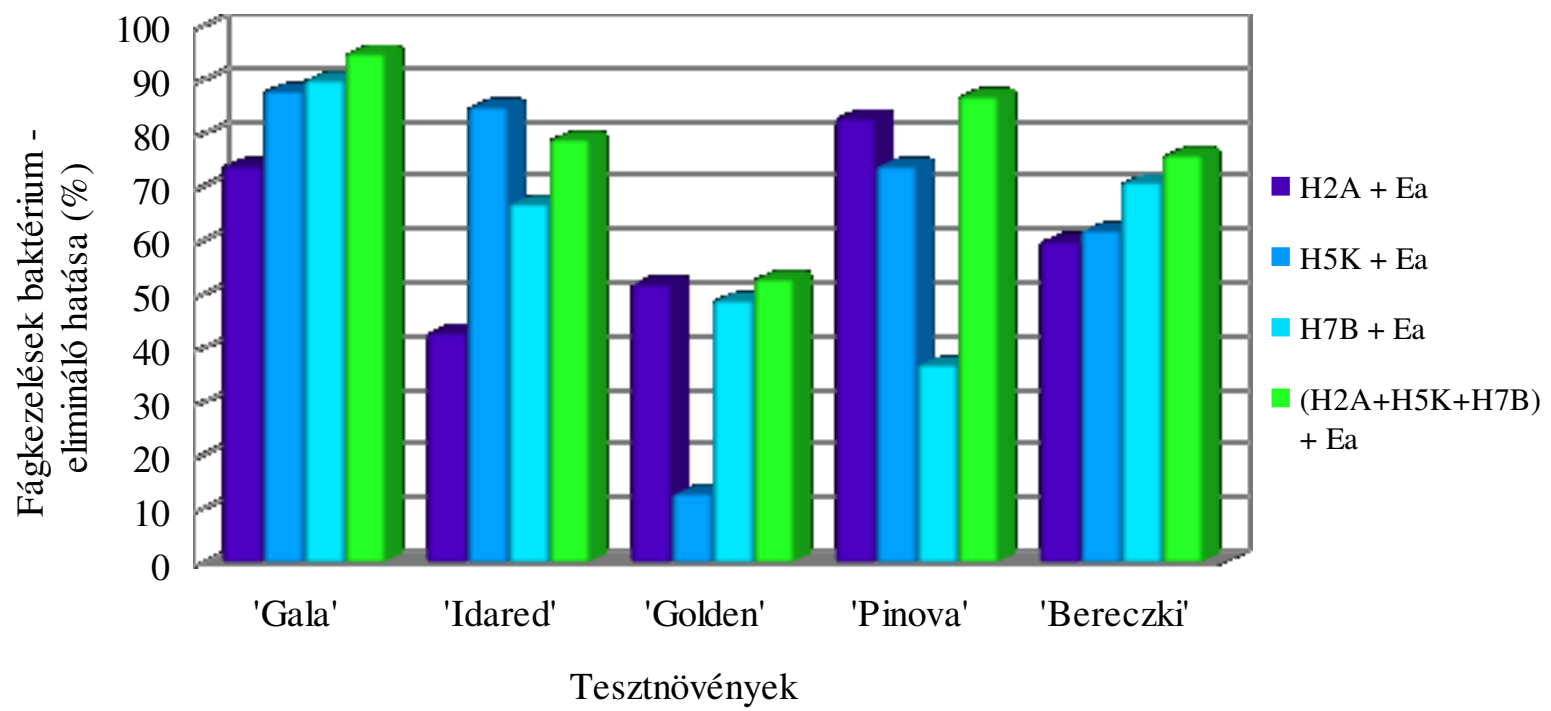

22. ábra Fágizolátumok és kombinációjuk E. amylovora gátló hatása különböző almafajták ('Gala Schniga', 'Idared', 'Golden delicious Reinders', 'Pinova') és egy birsfajta ('Bereczki') virágain (2011). Az eltérö színnel jelölt oszlopok a négyféle fágkezelésnek a pozitív kontrollhoz viszonyított százalékos hatékonyságát mutatják (mintaszám: 15/kezelés/fajta).

12. táblázat Fágizolátumok és kombinációjuk E. amylovora gátló hatása különböző almafajták és egy birsfajta virágain (2011) - statisztikai összefoglaló (MANOVA, F-próba)

\begin{tabular}{|c|c|c|c|c|c|}
\hline \multicolumn{6}{|c|}{ Átlagos baktérium kolóniaszám } \\
\hline \multirow[b]{2}{*}{ Kezelések } & \multicolumn{5}{|c|}{ Tesztnövény fajták } \\
\hline & 'Gala Schniga' & 'Idared' & $\begin{array}{l}\text { 'Golden delicious } \\
\text { Reinders" }\end{array}$ & 'Pinova' & 'Bereczki' \\
\hline $\mathrm{H} 2 \mathrm{~A}+\mathrm{Ea}$ & $15^{\mathrm{a}}$ & $885^{b}$ & $264^{\mathrm{a}}$ & $82^{a}$ & $449^{\mathrm{a}}$ \\
\hline $\mathrm{H} 5 \mathrm{~K}+\mathrm{Ea}$ & $7^{\mathrm{a}}$ & $232^{\mathrm{a}}$ & $812^{c}$ & $126^{\mathrm{a}}$ & $426^{\mathrm{a}}$ \\
\hline $\mathrm{H} 7 \mathrm{~B}+\mathrm{Ea}$ & $6^{\mathrm{a}}$ & $484^{\mathrm{a}}$ & $473^{a b}$ & $305^{b}$ & $329^{a}$ \\
\hline$(\mathrm{H} 2 \mathrm{~A}+\mathrm{H} 5 \mathrm{~K}+\mathrm{H} 7 \mathrm{~B})+\mathrm{Ea}$ & $3^{a}$ & $328^{\mathrm{a}}$ & $434^{\mathrm{a}}$ & $61^{\mathrm{a}}$ & $267^{\mathrm{a}}$ \\
\hline $\begin{array}{l}\mathrm{H}_{2} \mathrm{O}+\mathrm{Ea} \text { (pozitív } \\
\text { kontroll) }\end{array}$ & $58^{\mathrm{b}}$ & $1551^{\mathrm{c}}$ & $930^{c}$ & $486^{c}$ & $1131^{b}$ \\
\hline $\mathrm{LSD}_{0.05}$ & 14 & 447 & 190 & 147 & 300 \\
\hline $\mathrm{F}_{\text {exp. } 0.05}$ & 46 & 26 & 39 & 27 & 24 \\
\hline $\mathrm{F}_{0.05}$ & 2,5 & & & & \\
\hline
\end{tabular}

Az értékek az $50 \mu \mathrm{l}$ 10000-szeres hígítású minták szélesztéséböl kapott kolóniák számát jelölik 15, az erviniás kontroll esetében 20 minta átlagában. Az értékek feletti kisbetűk a kezelések közötti szignifikáns különbséget jelentik $(\mathrm{P}=0,01)$ szinten.

A fágkezelések tesztnövények közötti hatását összehasonlítva szignifikáns különbségeket tudtunk megállapítani (13. táblázat). A H2A fágkezelés hatására minden fajtán szignifikánsan lecsökkent a visszaizolált baktériumok mennyisége az 'Idared' fajtán mértekéhez képest. A H5K 
a 'Golden delicious Reinders' virágain volt a legkevésbé hatékony valamennyi fajta párosításában. A H7B fág a 'Gala' fajtán, míg a fágkombináció a 'Gala Schniga' és a 'Pinova' fajtákon bizonyult szignifikánsan hatékonyabbnak a többi fajtához képest.

13. táblázat Fágizolátumok és kombinációjuk E. amylovora gátló hatása különböző almafajták és egy birsfajta virágain (2011) - a kezelések fajták közötti hatásának összehasonlító statisztikai összefoglalója

\begin{tabular}{|l|l|l|l|l|l|}
\hline \multicolumn{1}{|c|}{$\begin{array}{c}\text { Tesztnövény } \\
\text { fajták }\end{array}$} & \multicolumn{5}{c|}{ Kezelések } \\
\cline { 2 - 7 } & H2A & H5K & H7B & H2A+H5K+H7B & Ea (Ea1/79Sm) \\
\hline 'Gala Schniga' & $15^{\mathrm{a}}$ & $7^{\mathrm{a}^{\prime}}$ & $6^{\mathrm{a}}$ & $3^{\mathrm{a}}$ & $58^{\mathrm{a}}$ \\
\hline 'Idared' & $885^{\mathrm{c}}$ & $232^{\mathrm{bd}}$ & $484^{\mathrm{b}}$ & $328^{\mathrm{b}}$ & $1551^{\mathrm{b}}$ \\
\hline $\begin{array}{l}\text { 'Golden delicious } \\
\text { Reinders' }\end{array}$ & $264^{\mathrm{a}}$ & $812^{\mathrm{c}}$ & $473^{\mathrm{b}}$ & $434^{\mathrm{b}}$ & $930^{\mathrm{d}}$ \\
\hline 'Pinova' & $82^{\mathrm{a}^{\prime}}$ & $126^{\mathrm{ab}}$ & $305^{\mathrm{b}}$ & $61^{\mathrm{a}}$ & $486^{\mathrm{c}}$ \\
\hline 'Bereczki' & $449^{\mathrm{b}}$ & $426^{\mathrm{d}}$ & $329^{\mathrm{b}}$ & $267^{\mathrm{b}}$ & $1131^{\text {ed }}$ \\
\hline
\end{tabular}

Az értékek az $50 \mu 1$ 10000-szeres hígítású minták szélesztéséből kapott kolóniák számát jelölik 15, illetve az erviniás kontroll esetében 20 minta átlagában. A felső indexben szerpelő kisbetük a fajták közötti szignifikáns különbséget jelentik ( $\mathrm{P}=0,01$ szinten, kivéve a', mely b-től (H2A), illetve bd-től $(\mathrm{H} 5 \mathrm{~K}) \mathrm{P}=$ 0,05 szinten tér el).

A 2012. évi alma- és birsvirágokon végzett kísérletben valamennyi fágkezelés hatására lecsökkent a visszaizolált baktériumok száma a kezeletlen kontrollhoz képest (23. ábra). A H7B fág, a fágkombináció, valamint a H2A az 'Idared' és a birs kivételével mindegyik tesztnövényen szignifikánsan hatékonyabb volt az erviniás kontrollhoz viszonyítva. A fajták többségében, a 'Gala Schniga', a 'Golden delicious Reinders' és a 'Berecki birs' esetében a fágkombináció eredményezte a legjobb hatást; legeredményesebb a 'Golden delicious Reinders' almafajta virágain volt, ahol 77\%-kal lecsökkentette a baktérium-populációt a kezeletlen pozitív kontrollhoz képest. A 'Berecki' birsvirágokon a fágkoktél szignifikánsan hatékonyabb volt a H2A fágos kezeléshez képest is. A többi esetben az egyes fágkezelések hatása között nem volt szignifikáns különbség (14. táblázat). A vizes kontrollok mind negatívnak bizonyultak. 


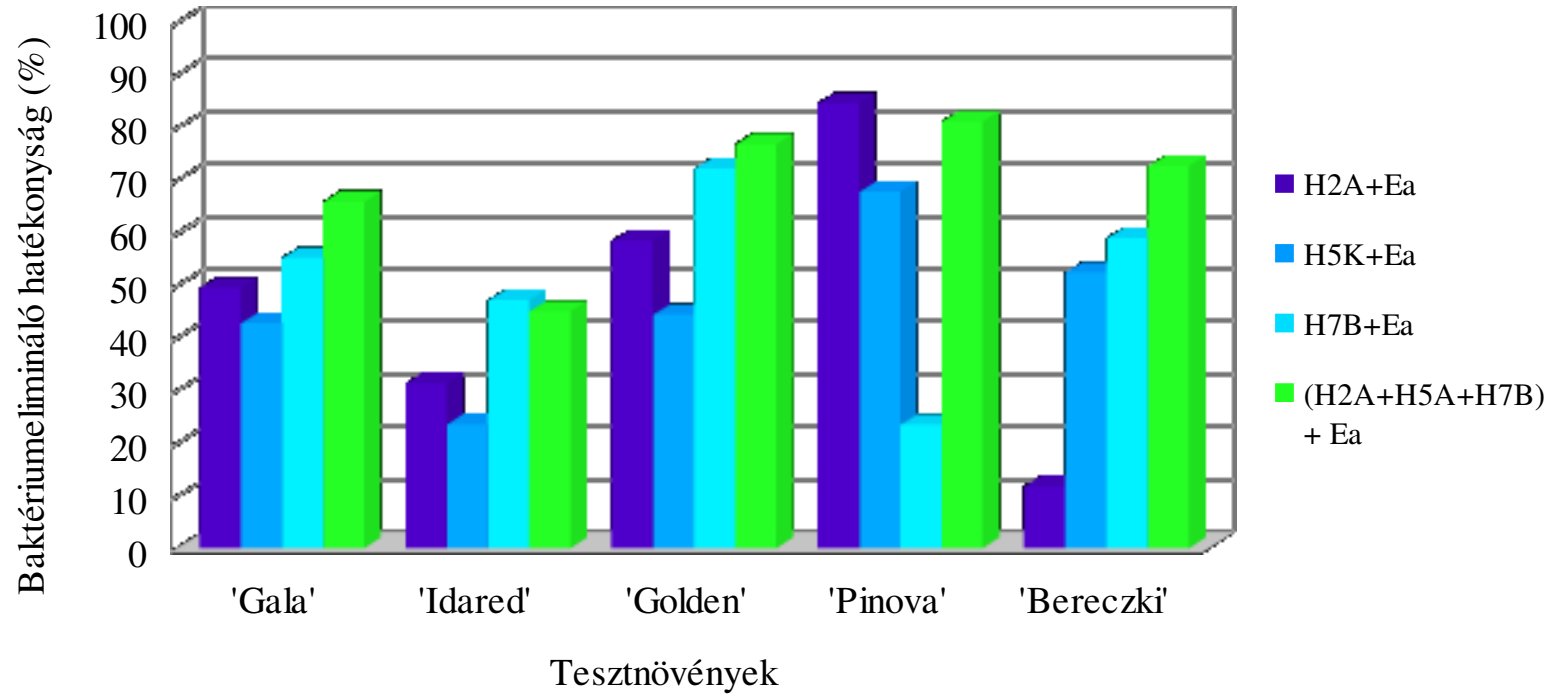

23. ábra Fágizolátumok és kombinációjuk E. amylovora gátló hatása különböző almafajták ('Gala Schniga', 'Idared', 'Golden delicious Reinders', 'Pinova') és egy birsfajta ('Bereczki') virágain (2012). Az eltérő színü oszlopok a négyféle fágkezelésnek a pozitív kontrollhoz viszonyított százalékos hatékonyságát mutatják (mintaszám: 15/kezelés/fajta).

14. táblázat Fágizolátumok és kombinációjuk E. amylovora gátló hatása különböző almafajták és egy birsfajta virágain (2012)

\begin{tabular}{|c|c|c|c|c|c|}
\hline \multicolumn{6}{|c|}{ Átlagos baktérium kolóniaszám } \\
\hline \multirow[b]{2}{*}{ Kezelések } & \multicolumn{5}{|c|}{ Tesztnövény fajták } \\
\hline & 'Gala Schniga' & 'Idared' & $\begin{array}{l}\text { 'Golden delicious } \\
\text { Reinders' }\end{array}$ & 'Pinova' & 'Bereczki' \\
\hline $\mathrm{H} 2 \mathrm{~A}+\mathrm{Ea}$ & $278^{\mathrm{a}}$ & $499^{\mathrm{ab}}$ & $395^{\mathrm{a}}$ & $115^{a^{\prime}}$ & $751^{\mathrm{ac}}$ \\
\hline $\mathrm{H} 5 \mathrm{~K}+\mathrm{Ea}$ & $315^{\mathrm{ab}}$ & $556^{\mathrm{ab}}$ & $529^{\mathrm{ab}}$ & $239^{a}$ & $406^{\mathrm{abc}}$ \\
\hline $\mathrm{H} 7 \mathrm{~B}+\mathrm{Ea}$ & $247^{\mathrm{a}}$ & $384^{\mathrm{a}}$ & $265^{a^{\prime}}$ & $567^{\mathrm{a}}$ & $350^{\mathrm{ab}}$ \\
\hline$(\mathrm{H} 2 \mathrm{~A}+\mathrm{H} 5 \mathrm{~K}+\mathrm{H} 7 \mathrm{~B})+\mathrm{Ea}$ & $188^{\mathrm{a}^{\prime}}$ & $400^{\mathrm{a}}$ & $221^{a^{\prime}}$ & $140^{\mathrm{a}^{\prime}}$ & $233^{\mathrm{b} "}$ \\
\hline $\begin{array}{l}\mathrm{H}_{2} \mathrm{O}+\mathrm{Ea} \text { (pozitív } \\
\text { kontroll) }\end{array}$ & $550^{\mathrm{b}^{\prime}}$ & $840^{\mathrm{b}}$ & $949^{b^{\prime}}$ & $741^{b^{\prime}}$ & $851^{\mathrm{c}^{\prime \prime}}$ \\
\hline
\end{tabular}

Az értékek a virágokról visszaizolált minták (50 $\mu 1$, 10000-szeres hígítás) szélesztéséből kapott kolóniák 15, az erviniás kontroll esetében 20 minta átlagában vett számát jelölik. A felső indexben szereplő kisbetűk a Tukey-féle post hoc teszt alapján számított, az egyes kezelések fajtán belüli szignifikáns eltéréseit jelölik $\left(\mathrm{P}=0,05\right.$ szinten, kivéve $\mathrm{a}^{\prime}$, mely b'-töl és $\mathrm{b}^{\prime \prime}$, mely c"-től $\mathrm{P}=0,01$ szinten tér el egymástól).

A fágkezelések tesztnövények közötti hatásának tekintetében (15. táblázat) elmondható, hogy a H2A fág a 'Gala Schniga' és a 'Pinova' fajtákon szignifikánsan hatékonyabbnak bizonyult, mint a 'Berecki' virágokon. Továbbá a három fág kombinációjának alkalmazása a 'Pinova' virágokon szignifikánsan visszaszorította a baktériumok számát az 'Idared' fajtán mértekhez képest. Azonban a többi fajta között nem volt szignifikáns különbség. A két ismétlés 
eredményeiből azonban nem kaptunk egyértelmü választ arra, hogy a kezelések hatékonysága határozottan függ-e a gazdanövény fogékonyságától.

15. táblázat Fágizolátumok és kombinációjuk E. amylovora gátló hatása különböző almafajták és egy birsfajta virágain (2012) - a kezelések fajták közötti hatásának összehasonlítása

\begin{tabular}{|l|l|l|l|l|l|}
\hline \multicolumn{1}{c|}{\begin{tabular}{c} 
Tesztnövény \\
\multicolumn{1}{c|}{ fajták }
\end{tabular}} & \multicolumn{5}{c|}{ Kezelések } \\
\cline { 2 - 6 } & $\mathrm{H} 2 \mathrm{~A}+\mathrm{Ea}$ & $\mathrm{H} 5 \mathrm{~K}+\mathrm{Ea}$ & $\mathrm{H} 7 \mathrm{~B}+\mathrm{Ea}$ & $(\mathrm{H} 2 \mathrm{~A}+\mathrm{H} 5 \mathrm{~K}+\mathrm{H} 7 \mathrm{~B})+\mathrm{Ea}$ & $\mathrm{H}_{2} \mathrm{O}+\mathrm{Ea}$ \\
\hline 'Gala Schniga' & $278^{\mathrm{a}}$ & $315^{\mathrm{a}}$ & $247^{\mathrm{a}}$ & $188^{\mathrm{ab}}$ & $550^{\mathrm{a}}$ \\
\hline 'Idared' & $499^{\mathrm{ab}}$ & $556^{\mathrm{a}}$ & $384^{\mathrm{a}}$ & $400^{\mathrm{a}}$ & $840^{\mathrm{a}}$ \\
\hline $\begin{array}{l}\text { 'Golden delicious } \\
\text { Reinders' }\end{array}$ & $395^{\mathrm{ab}}$ & $529^{\mathrm{a}}$ & $265^{\mathrm{a}}$ & $221^{\mathrm{ab}}$ & $949^{\mathrm{a}}$ \\
\hline 'Pinova' & $115^{\mathrm{a}}$ & $239^{\mathrm{a}}$ & $567^{\mathrm{a}}$ & $140^{\mathrm{b}}$ & $741^{\mathrm{a}}$ \\
\hline 'Bereczki' & $751^{\mathrm{b}}$ & $406^{\mathrm{a}}$ & $350^{\mathrm{a}}$ & $233^{\mathrm{ab}}$ & $851^{\mathrm{a}}$ \\
\hline
\end{tabular}

Az értékek a virágokról visszaizolált minták (50 $\mu \mathrm{l}$, 10000-szeres hígítás) szélesztéséből kapott kolóniaszámát jelölik 15, az erviniás kontroll esetében 20 minta átlagában. Az (a) és (b) betük a fajták közötti szignifikáns különbséget jelentik ( $\mathrm{P}=0,01$ szinten, kivéve a', mely b'-töl $\mathrm{P}=0,05$ szinten tér el).

\subsubsection{Valós idejü PCR vizsgálat}

Az 'Idared' fajta virágairól visszaizolált mintákat (2012) valós idejü (,real time”) PCR vizsgálatnak alávetve, a kapott ciklusszámokat összevetettük a referencia értékekkel, így következtetni tudtunk a minták sejtszámára, majd a kapott adatokat összehasonlítottuk a szélesztéses módszer eredményeivel. A telepszámlálással nyert eredményeink végül a kvantitatív valós idejü PCR technikával is megerösítést nyertek, mivel az egyes mintákban a baktérium mennyisége a telepszámláláshoz hasonló tendenciákat mutatott (24. ábra). A pozitív kontrollhoz képest csökkent mennyiségeket igazoltunk a fággal kezelt mintákban, de a H5A esetében ez a csökkenés nem volt szignifikáns (T-próba). A leghatékonyabbnak a H7B törzs bizonyult: harmadára csökkentette a baktériumszámot. A vízzel kezelt negatív kontrollban elhanyagolhatóan kis mennyiségü E. amylovora jelenléte a vizsgálati módszer nagyfokú érzékenységéből fakad, nem jelenti azt, hogy valóban jelen volt a baktérium a mintában. 

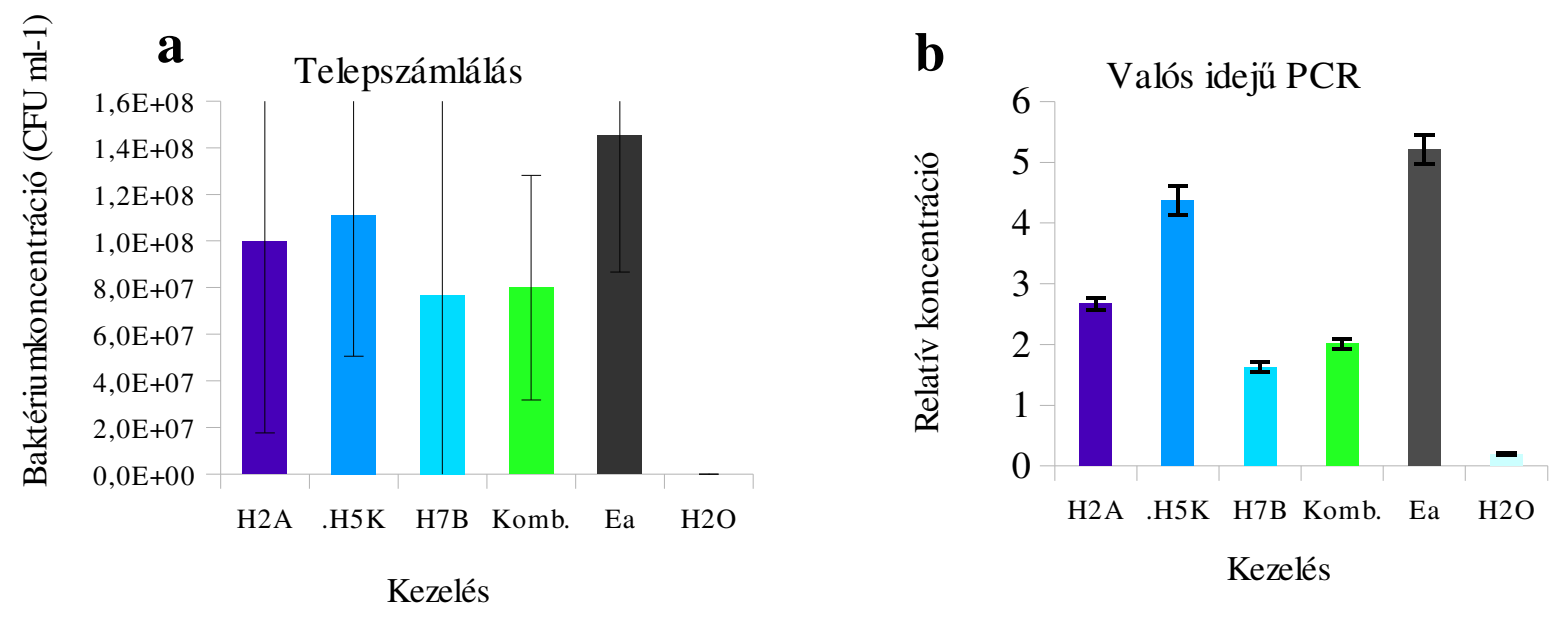

24. ábra Fágizolátumok $\left(\mathrm{H} 2 \mathrm{~A}, \mathrm{H} 5 \mathrm{~K}, \mathrm{H} 7 \mathrm{~B}, 10^{12} \mathrm{PFU} \mathrm{ml}^{-1}\right)$ és hármas $1: 1: 1$ arányú kombinációjuk $E$.

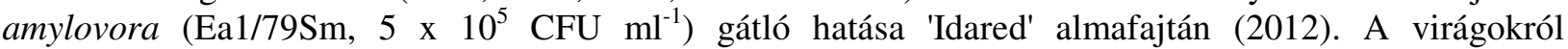
visszaizolált minták szélesztésből kapott telepszámlálási (a) és a valós idejü PCR vizsgálatból származó adatok (b) összevetése. Az ábrázolt értékek hat kezelés \pm SE átlagát mutatják (mintaszám $=$ kezelésenként 15, az erviniás kontroll esetében 20). A (b) ábrán szemléltetett értékek meghatározása a mellékletekben elhelyezett kalibrációs görbe (M19) alapján történt.

\subsubsection{FÁG HATÁSVIZSGÁLAT ÉRETLEN KÖRTESZELETEN}

Három körtefajta ('Conference', 'Dr. Guyot Gyula', 'Erdei vajkörte') éretlen gyümölcsszeletein vizsgálva a virágkísérletek során is tesztelt fágizolátumok (H2A, H5K, H7B) és hármas kombinációjuk baktérium-visszaszorító hatását azt tapasztaltuk, hogy általánosságban a fágkombinációkkal történt kezelések mindhárom fajta esetén szignifikánsan csökkentették a tüneteket az erviniás kontrollhoz viszonyítva. A legsúlyosabb tünetek a 'Conference', a legenyhébbek az 'Erdei vajkörte' fajtán voltak megfigyelhetők. A kísérletben (25. ábra) a H5K és a fágkombináció szignifikánsan hatékonyabb volt a pozitív kontrollhoz képest mindhárom fajta esetén, de a fágos kezelések nem különböztek szignifikánsan egymástól. A kezelések fajták közötti összefüggéseinek a vizsgálatából az derült ki, hogy a 'Dr. Guyot Gyula' és az 'Erdei vajkörte' szeleteken szignifikánsan mérsékeltebben jelentkeztek az erviniás fertőzés következtében kialakuló tünetek a 'Conference' fajtához képest valamennyi fágos kezelés esetén (16. táblázat), és hogy a fágkombináció az 'Erdei vajkörte'-n volt a leghatékonyabb. A fágok baktérium-elimináló hatása azonban messze elmaradt a sztreptomicin-szulfátétól; a sztreptomicinnel kezelt körteszeletek mindegyike tünetmentes maradt. 


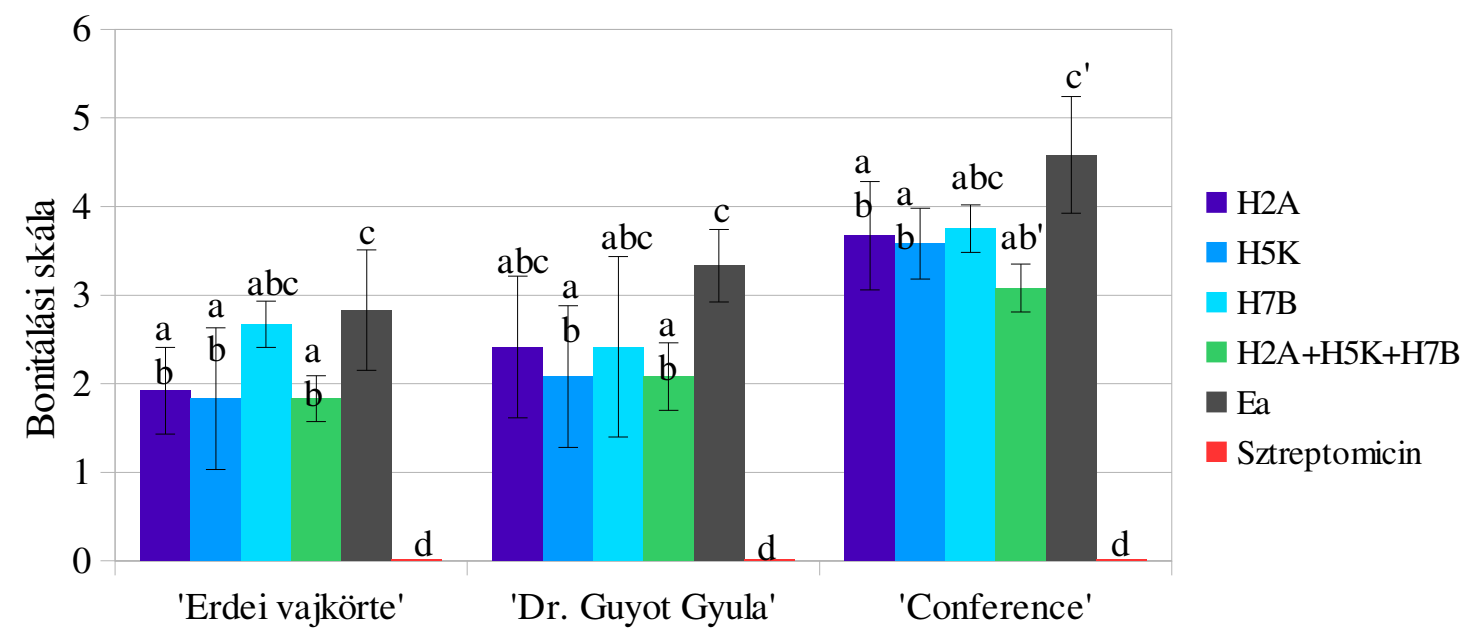

Körtefajták

25. ábra Fágizolátumok és kombinációjuk E. amylovora (Ea1/79) okozta tünetekre kifejtett hatása különböző körtefajták zöld gyümölcsszeletein (I. kísérlet). Az ábrázolt értékek hat kezelés \pm SE átlagát mutatják (6 minta/kezelés). Az oszlopok fölötti különböző betük a Tukey-féle post hoc teszt alapján számított, az egyes kezelések fajtán belüli szignifikáns különbségeit jelzik ( $\mathrm{P}=0,05$ szinten, kivéve ab', mely c'-töl $\mathrm{P}=0,01$ szinten tér el).

16. táblázat Fágizolátumok és kombinációjuk E. amylovora okozta tünetekre kifejtett hatása különböző körtefajták zöld gyümölcsszeletein (I. kísérlet) - a kezelések fajták közötti hatásának összehasonlító statisztikai összefoglalója

\begin{tabular}{|l|l|l|l|l|l|l|}
\hline \multirow{2}{*}{$\begin{array}{c}\text { Tesztnövény } \\
\text { fajták }\end{array}$} & \multicolumn{7}{c|}{ Kezelések } \\
\cline { 2 - 8 } & $\mathrm{H} 2 \mathrm{~A}+\mathrm{Ea}$ & $\mathrm{H} 5 \mathrm{~K}+\mathrm{Ea}$ & $\mathrm{H} 7 \mathrm{~B}+\mathrm{Ea}$ & $(\mathrm{H} 2 \mathrm{~A}+\mathrm{H} 5 \mathrm{~K}+\mathrm{H} 7 \mathrm{~B})+\mathrm{Ea}$ & $\mathrm{H}_{2} \mathrm{O}+\mathrm{Ea}$ & $\mathrm{Sm}+\mathrm{Ea}$ \\
\hline 'Erdei vajkörte' & $1,92^{\mathrm{a}}$ & $1,83^{\mathrm{a}}$ & $2,67^{\mathrm{a}}$ & $1,83^{\mathrm{a}}$ & $2,83^{\mathrm{a}}$ & $0^{\mathrm{a}}$ \\
\hline 'Dr. Guyot Gyula' & $2,42^{\mathrm{a}^{\mathrm{a}}}$ & $2,08^{\mathrm{a}}$ & $2,42^{\mathrm{a}^{\prime \prime}}$ & $2,08^{\mathrm{a}}$ & $3,33^{\mathrm{a}}$ & $0^{\mathrm{a}}$ \\
\hline 'Conference' & $3,67^{\mathrm{b}^{\mathrm{b}}}$ & $3,58^{\mathrm{b}}$ & $3,75^{\mathrm{b}^{\prime \prime}}$ & $3,08^{\mathrm{b}}$ & $4,58^{\mathrm{b}}$ & $0^{\mathrm{a}}$ \\
\hline
\end{tabular}

A számok a bonitálási skálaértékek (6 minta/kezelés) által takart tüneteket jelölik. Az „a” és „,b” betűk a fajták közötti szignifikáns különbséget jelentik ( $\mathrm{P}=0,01$ szinten, kivéve a', mely b'-től (H2A), illetve a", mely b"-től (H5K) P= 0,05 szinten tér el). Ea: E. amylovora (Ea1/79); Sm: sztreptomicin.

A második kísérletben a 'Dr. Guyot Gyula' fajtán valamennyi kezelés szignifikánsan lecsökkentette a tüzelhalás tüneteit a pozitív kontrollhoz képest (26. ábra). Ez a hatás az 'Erdei vajkörte' esetében csak a H2A, míg a 'Conference' kezelésekor a H5K és a fágkombináció alkalmazásakor igazolódott. Az egyes fágos kezelések hatékonysága között a H2A fágnak a H7B fágtól való eltérését leszámítva nem volt szignifikáns különbség. A fágos kezelések fajták közötti hatását összehasonlítva megállapítható, hogy a H2A és a H5K fágkezelés hatására szignifikánsan mérséklődtek az erviniás tünetek a 'Dr. Guyot Gyula' és az 'Erdei vajkörte' fajtákon a 'Conference' fajtához képest (17. táblázat). A sztreptomicines kezelés ezúttal is szignifikánsan hatékonyabb volt a fágok baktérium-elimináló hatásánál. 


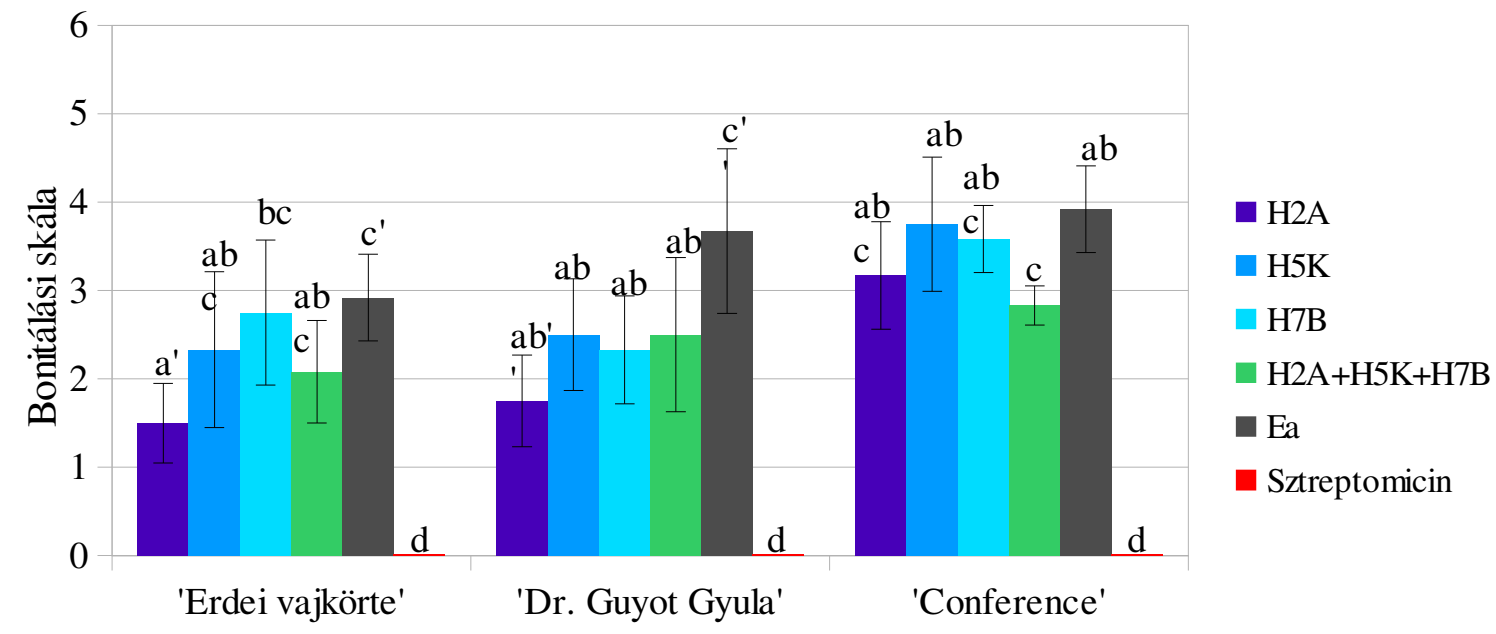

Körtefajták

26. ábra Fágizolátumok és kombinációjuk E. amylovora (Ea1/79) okozta tünetekre kifejtett hatása különböző körtefajták zöld gyümölcsszeletein (II. kísérlet). Az ábrázolt értékek hat kezelés \pm SE átlagát mutatják (6 minta/kezelés). Az oszlopok fölötti különböző betük a Tukey-féle post hoc teszt alapján számított, az egyes kezelések fajtán belüli szignifikáns különbségeit jelzik $(\mathrm{P}=0,05$ szinten, kivéve a', mely c'-től, ab", mely c"-től, illetve valamennyi d-től P=0,01 szinten tér el egymástól).

17. táblázat Fágizolátumok és kombinációjuk E. amylovora okozta tünetekre kifejtett hatása különböző körtefajták zöld gyümölcsszeletein (II. kísérlet) - a kezelések fajták közötti hatásának összehasonlítása

\begin{tabular}{|l|l|l|l|l|l|l|}
\hline \multicolumn{1}{c}{$\begin{array}{c}\text { Tesztnövény } \\
\text { fajták }\end{array}$} & \multicolumn{7}{c|}{ Kezelések } \\
\cline { 2 - 8 } & $\mathrm{H} 2 \mathrm{~A}+\mathrm{Ea}$ & $\mathrm{H} 5 \mathrm{~K}+\mathrm{Ea}$ & $\mathrm{H} 7 \mathrm{~B}+\mathrm{Ea}$ & $(\mathrm{H} 2 \mathrm{~A}+\mathrm{H} 5 \mathrm{~K}+\mathrm{H} 7 \mathrm{~B})+\mathrm{Ea}$ & $\mathrm{H}_{2} \mathrm{O}+\mathrm{Ea}$ & $\mathrm{Sm}+\mathrm{Ea}$ \\
\hline 'Erdei vajkörte' & $1,5^{\mathrm{a}^{\mathrm{a}}}$ & $2,33^{\mathrm{a}}$ & $2,75^{\mathrm{ab}}$ & $2,08^{\mathrm{a}}$ & $2,92^{\mathrm{a}}$ & $0^{\mathrm{a}}$ \\
\hline 'Dr. Guyot Gyula' & $1,75^{\mathrm{a}^{\prime}}$ & $2,5^{\mathrm{a}}$ & $2,33^{\mathrm{a}}$ & $2,5^{\mathrm{a}}$ & $3,67^{\mathrm{a}}$ & $0^{\mathrm{a}}$ \\
\hline 'Conference' & $3,17^{\mathrm{b}^{\prime}}$ & $3,75^{\mathrm{b}}$ & $3,58^{\mathrm{b}}$ & $2,83^{\mathrm{a}}$ & $3,92^{\mathrm{a}}$ & $0^{\mathrm{a}}$ \\
\hline
\end{tabular}

A számok a bonitálási skálaértékek (6 minta/kezelés) által takart tüneteket jelölik.A felső indexben szereplő betủk a fajták közötti szignifikáns különbséget jelentik ( $\mathrm{P}=0,05$ szinten, kivéve a', mely b'-től $\mathrm{P}=$ 0,01 szinten tér el). Ea: E. amylovora (Ea1/79); Sm: sztreptomicin.

\subsubsection{FÁG HATÁSVIZSGÁLAT DÍSZNÖVÉNYEKEN}

A kísérletben négy tüzelhalásra fogékony dísznövényfajon vizsgáltuk különböző fágkezelések baktérium-elimináló hatását (Nagy és mtsai. 2012). Mind a négy fajnál a legeredményesebbnek a $\mathrm{H} 2 \mathrm{~A}+\mathrm{H} 4 \mathrm{~A}+\mathrm{H} 5 \mathrm{~A}$ fágkoktél alkalmazása bizonyult (27. ábra). Az $E$. amylovora inokuláció következményeként kialakuló betegségtünetek mérséklésében a leghatékonyabb kezelést a tüztövis ( $P$. angustifolia) virágokra kijuttatott fágkombináció jelentette, mert abban az esetben a fertőzést követő negyedik napon a fággal kezelt vesszőkön nem volt megfigyelhető elbarnult vacokú virág, míg a kezeletlen kontroll virágok 29\%-a súlyos 
tüneteket mutatott. Ezzel ellentétben a házi berkenyén ( $C$. monogyna) és az egybibés galagonyán (S. domestica) a fágkoktél nem csökkentette le jelentős mértékben a virágnekrózis mértékét.

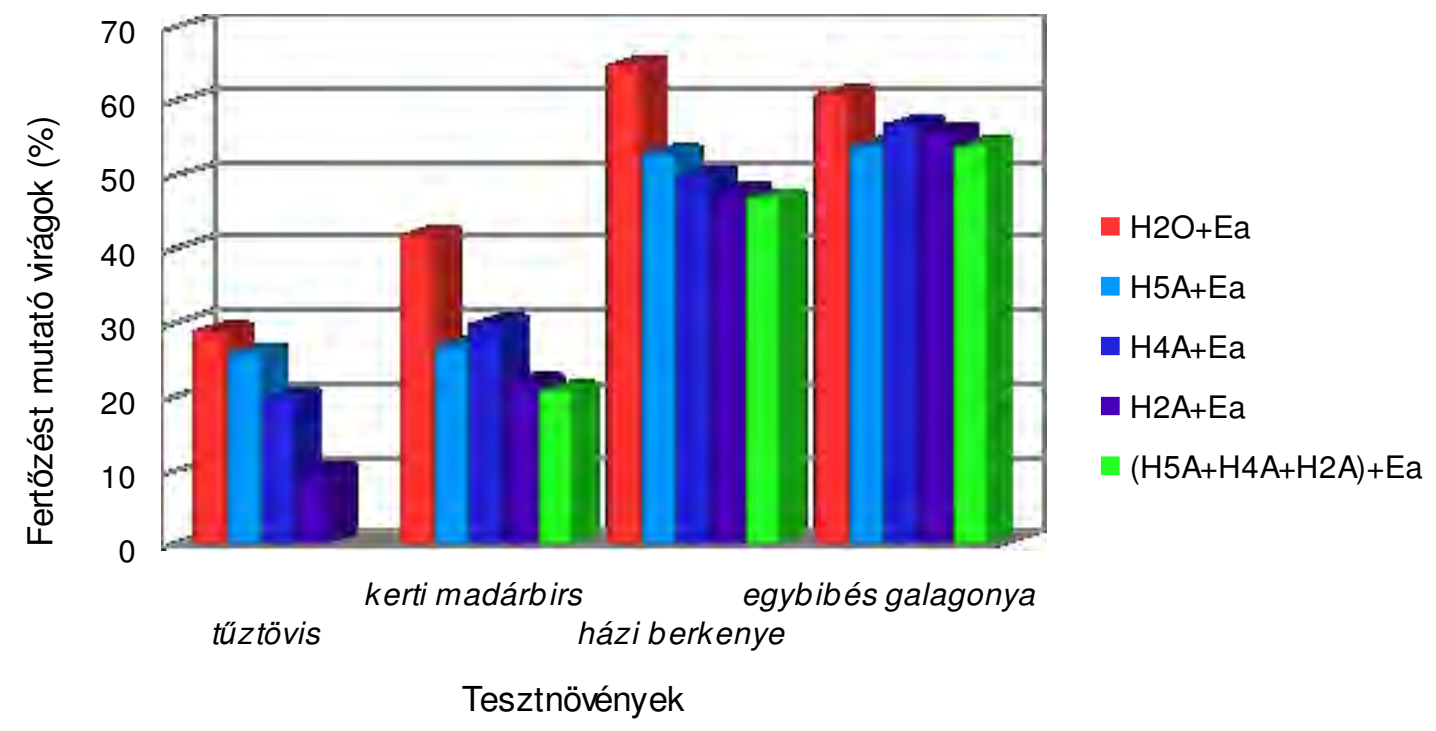

27. ábra Fágizolátumok és kombinációjuk hatása az E. amylovora baktériumra különböző dísznövényeken. Az egyes oszlopok az adott kezeléseket követően az erviniás inokuláció utáni negyedik napon a vackbarnulás tünetét mutató virágok arányát ábrázolják 100 véletlenszerúen kiválasztott virágból.

\subsection{A FÁGKEZELÉS HATÉKONYSÁGÁNAK FOKOZÁSÁRA IRÁNYU- LÓ VIZSGÁLATOK: FÁGOK NÖVÉNYBE JUTÁSA, TRANSZLO- KÁCIÓJA ÉS AZ E. AMYLOVORA OKOZTA TÜNETEKRE GYAKOROLT HATÁSA}

\subsubsection{A FÁGOK TRANSZLOKÁCIÓS KÉPESSÉGÉNEK ALMA CSÍRANÖVÉNYEKBEN TÖRTÉNŐ VIZSGÁLATA - ELŐKÍSÉRLET}

Előkísérletünk eredménye alapján elmondható, hogy a gyökérzónához kijuttatott vizes fágszuszpenzióval (H5K) történő egyszeri kezelés után már két nappal fágokat detektáltunk a növények felső szárrészében és leveleiben (18. táblázat). A perlites közeg a fágok növénybeni szállítódása szempontjából kedvezőbbnek bizonyult, mint a vizes kultúra. A kétnapos inkubációt követően direkt mintavétellel az egyik perlites közegből származó növényi mintából sikerült fágokat kimutatni. Az úgynevezett felszaporításos módszerrel viszont detektálni tudtuk a fágokat valamennyi perlitben elhelyezett növényböl és az egyik hidroponikus közegben kezelt növény mintájából is. A perlites kezelés esetén áttetszö összefüggő tar foltokat figyeltünk meg, ami magas fágkoncentrációra utal. A hatnapos inkubáció után mindegyik vizes közegben tartott növényből és az egyik perlites kezelésből származó növényi mintából ki tudtuk mutatni a fágok jelenlétét. Valamennyi vizes kontroll fágmentesnek bizonyult. A visszaizolált fágok által képzett plakkok morfológiája megegyezett az inokulumként használttal. 
18. táblázat $\mathrm{H} 5 \mathrm{~K}$ fágok növénybe jutása és in planta transzlokációja vízben (hidropóniás kultúra), illetve perlitben tartott alma csíranövények esetén

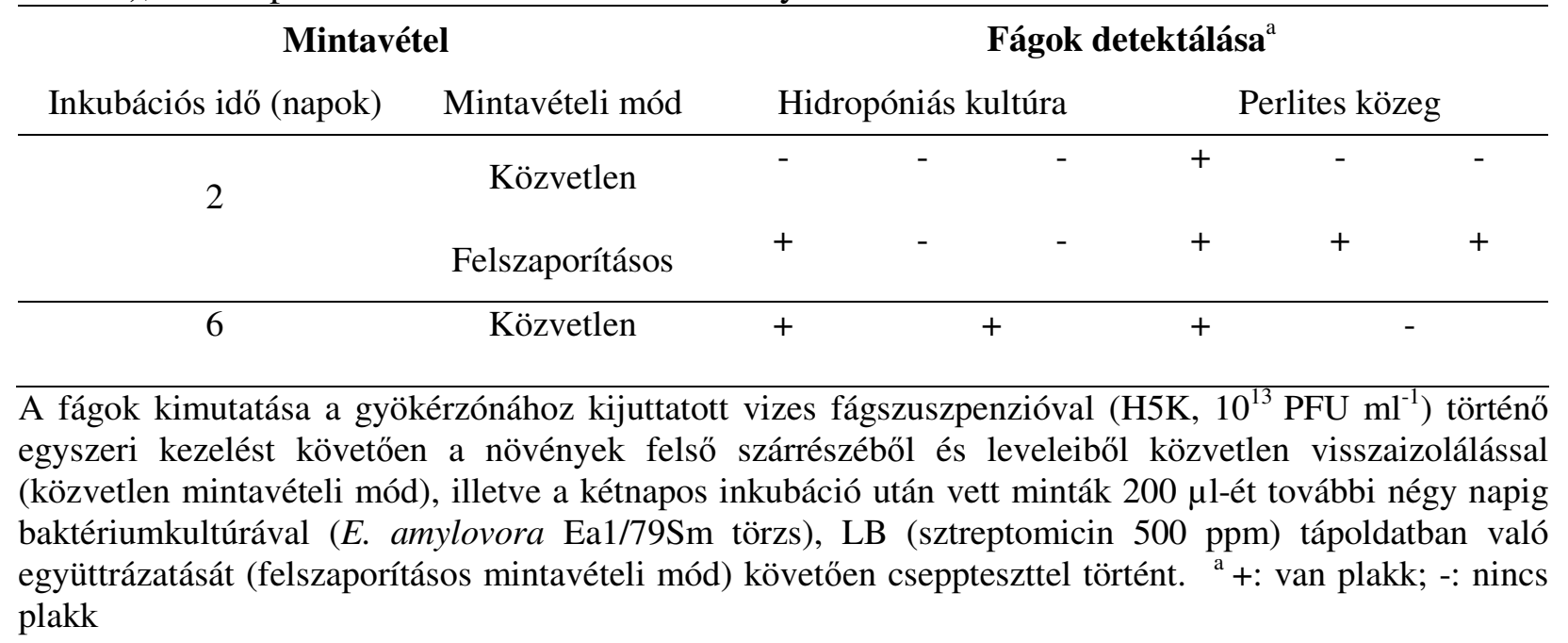

\subsubsection{FÁGOK SZÁLLÍTÓDÁSA ALMA CSÍRANÖVÉNYEKBEN}

A fágszuszpenziók (H5K, ill. ФEa104) almamagoncokhoz történő egyszeri kijuttatása után ki tudtuk mutatni a fágok jelenlétét mind a növény föld feletti részeiböl (a gyökérzóna kezelését követően), mind pedig a gyökérzetből (a növények alsó-, ill. felső szárrészénk permetezését követően). Mindkét fágizolátum használatakor a kezelés utáni első napon sikerült a legtöbb növényi mintából fágot visszaizolálni (19. táblázat). A kijutatott fágszuszpenzió sürüsége azonban jelentős mértékben lecsökkent $\left(10^{13} \mathrm{PFU} \mathrm{ml}^{-1}\right.$-ről $1,0-4,0 \times 10^{2} \mathrm{PFU} \mathrm{ml}{ }^{-1}$-re $)$ a közvetlen mintavétellel feltárt, életképes fágot tartamazó minták esetében.

A H5K fágizolátum szuszpenziójával történő kezelést követően a legtöbb mintából egy nap elteltével sikerült fágot kimutatnunk. Közvetlen mintavétellel a növények alsó szárrészéből két esetben, míg a gyökérzetből egy esetben voltak fágok kimutathatók a kezelés utáni első napon. A gyökérzetből még a kezelést követően öt nappal is sikerült fágot visszaizolálni. Az úgynevezett felszaporításos módszerrel több mintából, köztük a felső leveles szárrészből is tudtunk fágot detektálni az első, a második és az ötödik mintavételi napokon. Az így felszaporított mintákból szélesztve sok esetben áttetsző, összefüggő tar foltok jelentek meg a baktériumrétegen. A fágok kijuttatását követő hetedik napon már nem volt kimutatható a fágok jelenléte egyik kezelés esetén sem. A vizes kontrollok fágmentesnek bizonyultak. 
19. táblázat Fágizolátumok (H5K, ill. ФEa104) detektálása különböző növényi részekből alma csíranövényeken

\begin{tabular}{|c|c|c|c|c|c|c|c|c|c|c|c|c|c|c|c|c|c|c|c|}
\hline \multirow[t]{3}{*}{ Kezelés } & \multicolumn{2}{|c|}{ Mintavétel } & \multicolumn{17}{|c|}{ Fágok detektálása $^{a}$} \\
\hline & \multirow[t]{2}{*}{$\begin{array}{l}\text { Inkubációs } \\
\text { idő (napok) }\end{array}$} & \multirow[t]{2}{*}{ Mintavételi mód } & \multicolumn{5}{|c|}{ Alsó szárrészböl } & \multicolumn{6}{|c|}{$\begin{array}{c}\text { Felső szárrészböl } \\
\text { és levelekböl }\end{array}$} & \multicolumn{6}{|c|}{ Gyökérzetböl } \\
\hline & & & I & & & II. & & & I. & & & II & & & I. & & II & & \\
\hline $\mathrm{H}_{2} \mathrm{O}$ & 1 & Közvetlen & - & - & - & - & - & - & - & - & - & - & - & - & - & - & - & - & \\
\hline \multirow[t]{10}{*}{$\mathrm{H} 5 \mathrm{~K}$} & 1 & Közvetlen & $-t$ & - & - & + & - & - & - & - & - & - & - & - & + & - & - & $-\quad-$ & \\
\hline & & Felszaporításos & $+t$ & + & - & + & - & - & - & + & - & - & - & - & + & + & - & $-\quad-$ & \\
\hline & 2 & Közvetlen & - & - & - & - & - & - & + & - & - & - & - & - & - & - & - & $-\quad-$ & \\
\hline & & Felszaporításos & - & + & - & - & - & - & + & - & - & - & - & - & - & - & - & $-\quad-$ & \\
\hline & 3 & Közvetlen & - & - & - & - & - & - & - & - & - & - & - & - & - & - & - & $-\quad-$ & \\
\hline & & Felszaporításos & - & - & - & - & - & - & - & - & - & - & - & - & - & - & - & $-\quad-$ & \\
\hline & 5 & Közvetlen & - & - & - & - & - & - & - & - & - & - & - & - & - & - & - & $-\quad+$ & \\
\hline & & Felszaporításos & - & - & - & - & - & - & - & - & - & + & - & - & - & - & - & $-\quad+$ & \\
\hline & 7 & Közvetlen & - & - & - & - & - & - & - & - & - & - & - & - & - & - & - & $-\quad-$ & \\
\hline & & Felszaporításos & - & - & - & - & - & - & - & - & - & - & - & - & - & - & - & $-\quad-$ & \\
\hline \multirow[t]{10}{*}{$\Phi \mathrm{Ea} 104$} & 1 & Közvetlen & - & + & - & - & - & - & + & + & - & + & - & + & ++ & + & - & $-\quad+$ & \\
\hline & & Felszaporításos & -+ & + & - & - & - & - & + & + & - & + & - & + & ++ & + & - & $-\quad+$ & \\
\hline & 2 & Közvetlen & - & - & - & - & - & - & - & - & - & - & - & - & - & - & - & $-\quad-$ & \\
\hline & & Felszaporításos & -+ & - & - & - & - & - & + & + & - & - & - & - & - & - & - & $-\quad-$ & \\
\hline & 3 & Közvetlen & - & - & + & - & - & - & - & - & - & - & - & - & - & - & - & $-\quad-$ & \\
\hline & & Felszaporításos & - & - & + & - & - & - & - & - & - & - & - & - & - & - & - & $-\quad-$ & \\
\hline & 5 & Közvetlen & - & - & - & - & - & - & - & - & - & - & - & - & - & - & - & $-\quad-$ & \\
\hline & & Felszaporításos & - & - & - & - & - & - & - & - & - & - & - & - & - & - & - & $-\quad-$ & \\
\hline & 7 & Közvetlen & - & - & - & - & - & - & - & - & - & - & - & - & - & - & - & $-\quad-$ & \\
\hline & & Felszaporításos & - & - & - & - & - & - & - & - & - & - & - & - & - & - & & - & \\
\hline \multicolumn{20}{|c|}{ 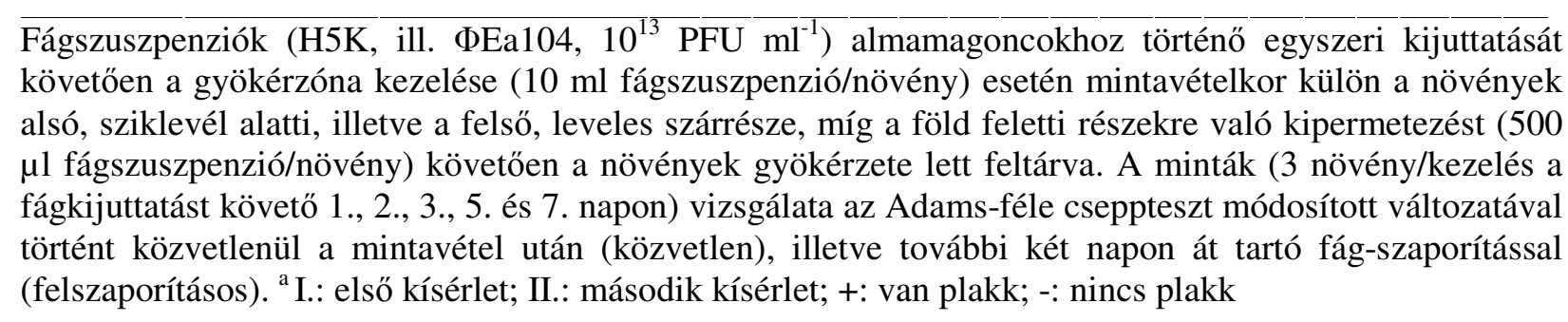 } \\
\hline
\end{tabular}


A ФEa104 fágszuszpenziónak a gyökérzónához, illetve a szár és levelek felületére való kijuttatását követően közvetlen mintavétellel az alsó szárrészből, a leveles felső szárrészből és a gyökérzetből egyaránt kimutatható volt a fágok jelenléte egy nappal a kezelés után (19. táblázat). Az alsó szárrészből a harmadik mintavételi napon is sikerült közvetlenül fágot visszaizolálni. A felszaporításos módszerrel a növények alsó, valamint a leveles felső szárrészéből tudtunk fágot kimutatni az első három mintavételi időpontban. A gyökérzetből csak egy nappal a permetezést követően sikerült fágot detektálnunk. Fágok a kezelést követő ötödik és hetedik napon már nem voltak kimutathatók.

\section{PCR vizsgálat}

PCR-es fág kimutatáshoz a ФEa104 fág esetén a génbanki adatok alapján általunk tervezett Ea104F/R primerpárt, a magyar H5K esetén a korábbi kísérleteinkben használt, termináz génre specifikus primereket használtuk. A felszaporításos módszerrel vizsgált, szélesztéskor plakkot adó pozitív mintákban a fágok in planta jelenlétét PCR módszerrel is sikerült igazolnunk: a H5K fág esetében 11 mintából 7 mintában (28. ábra), a ФEa104 fágnál 13 mintából 10 mintában (29. ábra).

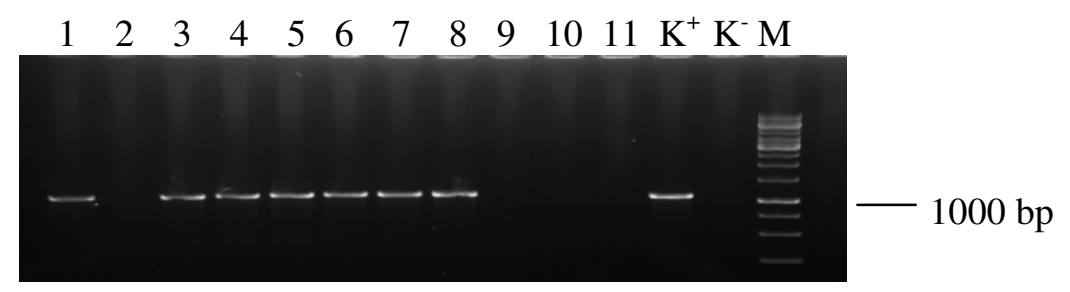

28. ábra A H5K fágizolátummal kezelt csíranövényekből a felszaporításos mintavétel során szélesztéssel pozitívnak bizonyult minták Term-F/R indító szenvenciapárral kapott PCR termékének (1079 bp) gélelektroforézis képe. A minták balról jobbra: I/1. 1a (Első kísérlet/1. nap, első növény, alsó szárrész), I/1. 2a, I/1. 3a, I/1. 3f (felső szárrész), I/1. 2gy (gyökér), I/1. 3gy, I/2. (második nap) 3a, I/2. 2f, II/1. 2a, II/5. 2f, II/5. 3gy, H5K (K ${ }^{+}$), víz (K'), GeneRuler ${ }^{\mathrm{TM}} 1 \mathrm{~kb}$ DNA Ladder Plus (Thermo Scientific) (M).

$\begin{array}{lllllllllllll}1 & 2 & 3 & 4 & 5 & 6 & 7 & 8 & 9 & 10 & 11 & 12 & 13 \mathrm{~K}^{+} \mathrm{K}^{-} \mathrm{M}\end{array}$

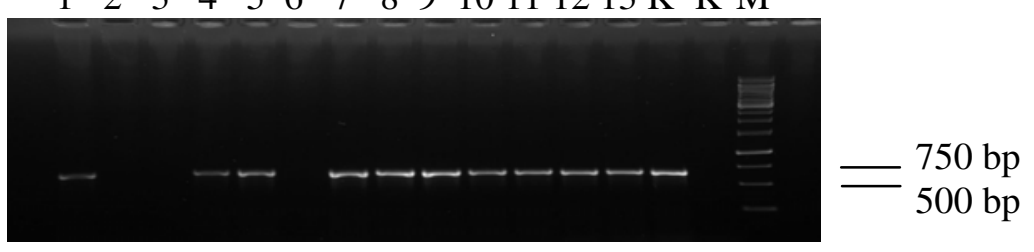

29. ábra A $\Phi E a 104$ fággal kezelt csíranövényekből a felszaporításos mintavétel során szélesztéssel pozitívnak bizonyult minták Ea104F/R primerpárral kapott PCR termékének (665bp) gélfotója. A minták balról jobbra: I/1. 2a (Első kísérlet/1. nap, második növény, alsó szárrész), I/1. 2f (felső szárrész), I/1. 3a, I/1. 3f, I/1. 1gy (gyökér), I/1. 2gy, I/1. 3gy, I/2. (második nap) 2a, I/2 2f, I/2 3f, II/1. 2f, II/1. 3gy, II/3 1a, $\Phi$ Ea104 $\left(\mathrm{K}^{+}\right)$, víz $\left(\mathrm{K}^{-}\right)$, GeneRuler ${ }^{\top \mathrm{M}} 1 \mathrm{~kb}$ DNA Ladder Plus (Thermo Scientific) (M). 


\subsubsection{A FÁGOK HATÁSA AZ E. AMYLOVORA OKOZTA TÜNETEKRE}

\subsubsection{Alma csíranövények gyökérzónájához, illetve a növény föld feletti részeire juttatva ki a fágokat}

A fágkezelés hatására mindkét kijuttatási mód esetén szignifikánsan lecsökkent az $E$. amylovora baktérium szuszpenziójával végzett inokuláció következményeként kialakuló tüzelhalás tünetek mértéke a kezeletlen kontrollhoz képest (30-31. ábra). A két koncentráció

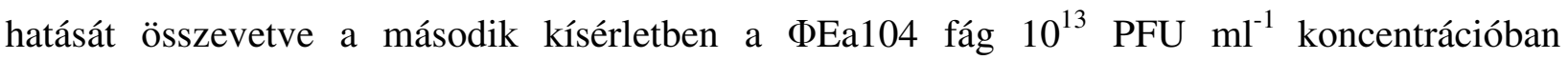
szignifikánsan mérsékelte a tüneteket a csíranövényeknek mind a gyökérzónája felé, mind pedig a lombozatára történő alkalmazása esetén. A második kísérletben az a kezelés, melynek során a H5K fágok vizes szuszpenzióját $10^{13} \mathrm{PFU} \mathrm{ml}^{-1}$ koncentrációban juttattuk a tesztnövények szárára és leveleire szignifikánsan hatékonyabbnak bizonyult az E. amylovora okozta tünetek mérséklésében ahhoz képes, amikor az alacsonyabb koncentrációban permeteztük a fágokat a növényre. Azonban a második kísérlet során mindkét fágtörzs kijuttatási módjai között egyik alkalmazott koncentrációban sem volt kimutatható szignifikáns különbség, noha a H5K fág $10^{13}$ PFU ml ${ }^{-1}$ koncentrációban hatékonyabb volt a lombozatra való kijuttatáskor, mint a gyökérzet felé történő alkalmazás esetén. Az ismétlések (I. és II. kísérlet) nem különböztek egymástól szignifikánsan. A kijuttatott fágok hatását a kezeléseket követő 13. napon már nem lehetett értékelni, mivel addigra a csíranövények zöme kiterjedt nekrózis tüneteit mutatta.

A

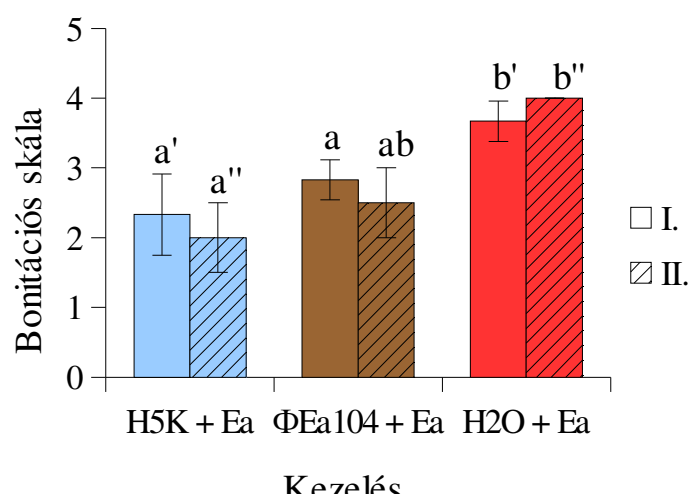

B

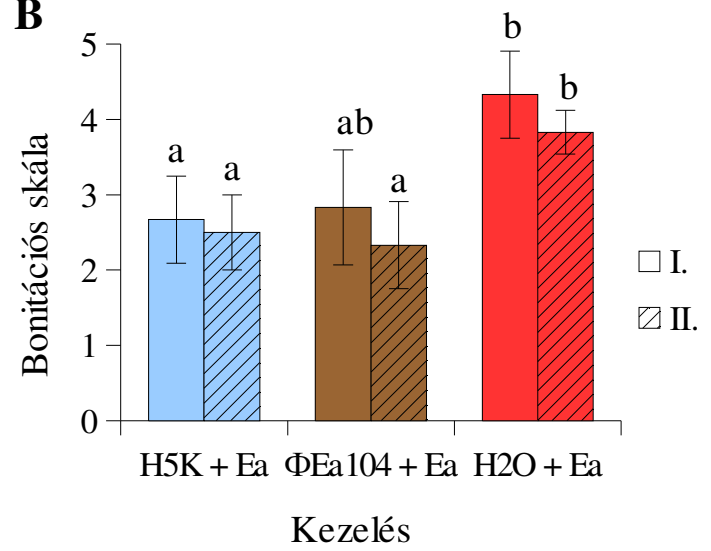

30. ábra Alma csíranövények gyökérzónájához (A), illetve levélzetére és szárára (B) az E. amylovora

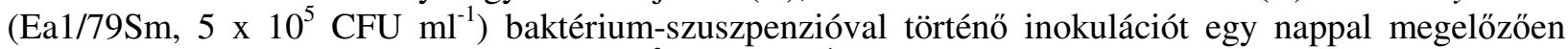
kijuttatott fágok $\left(\mathrm{H} 5 \mathrm{~K}\right.$, ill. ФEa104, $\left.10^{3} \mathrm{PFU} \mathrm{ml}^{-1}\right)$ hatása a kialakuló tüzelhalásos tünetekre a baktériumfertőzés utáni 5. napon. Az értékek két, egymástól külön ábrázolt független kísérlet (I., II.) \pm SE átlagát mutatják (3 minta/kísérlet) egy tünetmentes állapottól (0) a széles körü nekrózisig (5) terjedő bonitációs skála mentén. Az oszlopok fölötti kis betűk a Tukey-féle post hoc teszt alapján számított, az egyes kezelések közötti szignifikáns különbségeket jelzik $[\mathrm{P}=0,01$ szinten, kivéve a', mely b'-től, illetve a", mely b"-től csupán $\mathrm{P}=0,05$ szinten tér el egymástól (A)]. 


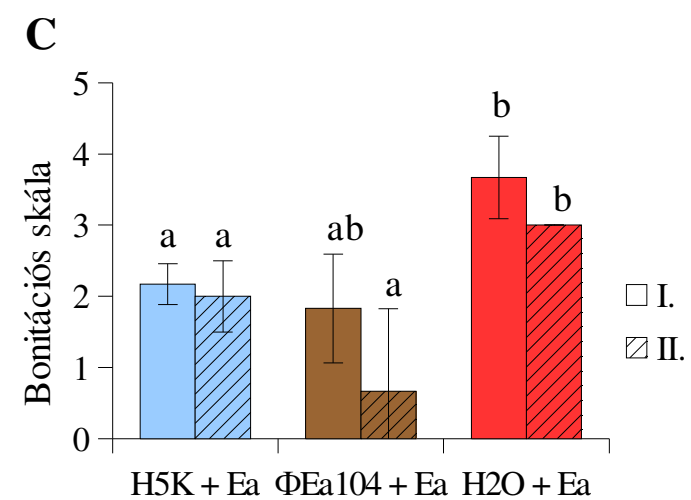

Kezelés
D

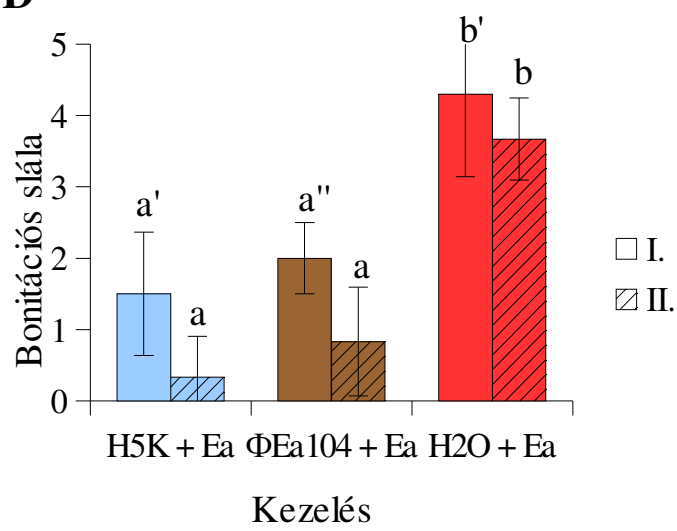

31. ábra Alma csíranövények gyökérzónájához (C), illetve levélzetére és szárára (D) az E. amylovora (Ea1/79Sm, $5 \times 10^{5} \mathrm{CFU} \mathrm{ml}^{-1}$ ) baktérium-szuszpenzióval történő inokulációt egy nappal megelőzően kijuttatott fágszuszpenziók (H5K, ill. $\Phi E a 10410^{13} \mathrm{PFU} \mathrm{ml}^{-1}$ ) hatása a tüzelhalásos tünetekre a baktériumfertőzést követő 5. napon. Az értékek két, külön ábrázolt független kísérlet (I., II.) \pm SE átlagát mutatják (3 minta/kísérlet) egy tünetmentestől (0) a széles körü nekrózis állapotáig terjedő bonitációs skála függvényében. Az oszlopok fölötti különböző betük a Tukey-féle post hoc teszt alapján számított, az egyes kezelések közötti szignifikáns különbségeket jelzik $[\mathrm{P}=0,01$ szinten, kivéve a' és a", melyek b'től csupán $\mathrm{P}=0,05$ szinten különböznek (D)].

\subsubsection{A fágokat alma csíranövények sziklevelébe injektálva}

Ebben a kísérletben oly módon vizsgáltuk a fágok E. amylovora okozta tünetek visszaszorításában jelentkező hatását, hogy a fágszuszpenziókat (H5K, illetve ФEa104) alma csíranövények egyik sziklevelébe juttatuk, majd közvetlenül utána baktérium-szuszpenziót cseppentve a fággal átitatott sziklevélre inokuláltuk a tesztnövényt. A fágkezeléseket követően a mesterséges fertőzés által előidézett tünetek mértékében, melyet egy előre felállított bonitálási skála alapján értékeltünk, szignifikáns csökkenés volt megfigyelhető a kezeletlen, pozitív kontrollhoz viszonyítva (32-33. ábra). Az öt napos inkubációs időszak alatt kialakult tünetek mértéke a H5K fágkezelés hatására az egymástól szignifikánsan nem különböző három ismétlés átlagában 45\%-kal, míg a ФEa104 alkalmazása esetén 67\%-kal mérséklődött. A két fág hatása között nem volt szignifikáns különbség. 


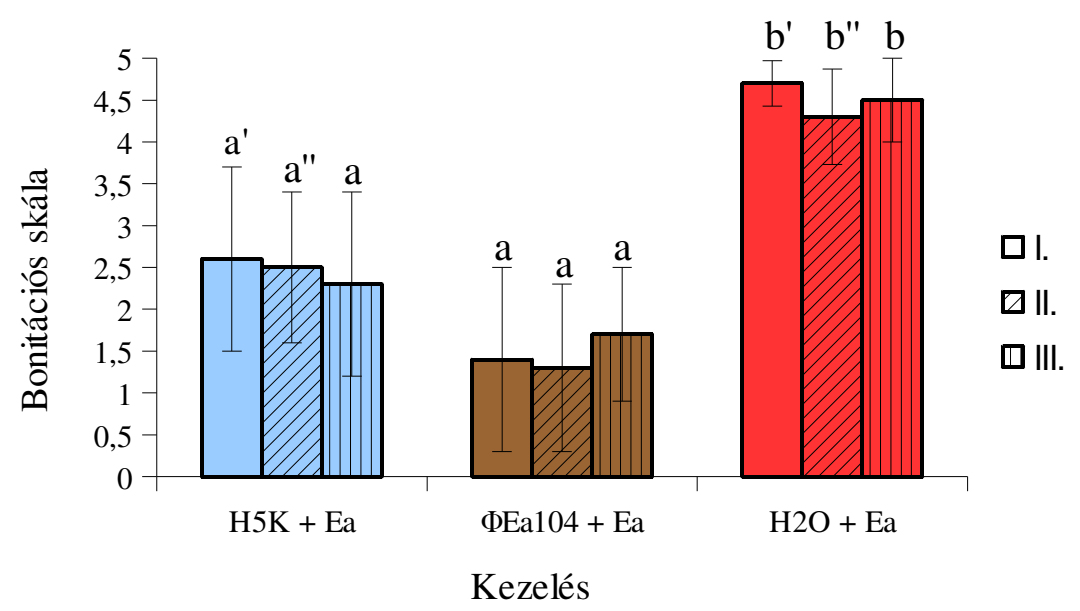

32. ábra Alma csíranövények egyik sziklevelébe injektált fágok $\left(\mathrm{H} 5 \mathrm{~K}\right.$, illetve $\Phi$ Ea104, $10^{13} \mathrm{PFU} \mathrm{ml^{-1 } )}$

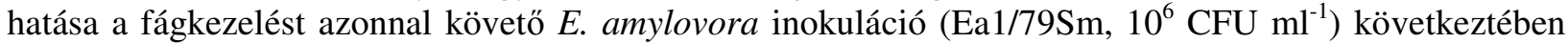
megjelenő betegségtünetek mértékére az erviniás kontrollhoz $\left(\mathrm{H}_{2} \mathrm{O}+\mathrm{Ea}\right)$ képest a fertőzés utáni ötödik napon. Az "ép, zöld sziklevél" (0) és a "mindkét sziklevél barna" (5) állapotok közötti értékek három, egymástól külön ábrázolt független kísérlet (I., II., III.) \pm SE átlagát mutatják (mintaszám= 5/kísérlet). A különböző betük a Tukey-féle post hoc teszt alapján számított, az egyes kezelések közötti szignifikáns különbségeket jelzik ( $\mathrm{P}=0,01$ szinten, kivéve a', mely b'-től és a", mely b"-től csupán $\mathrm{P}=0,05$ szinten különbözik).

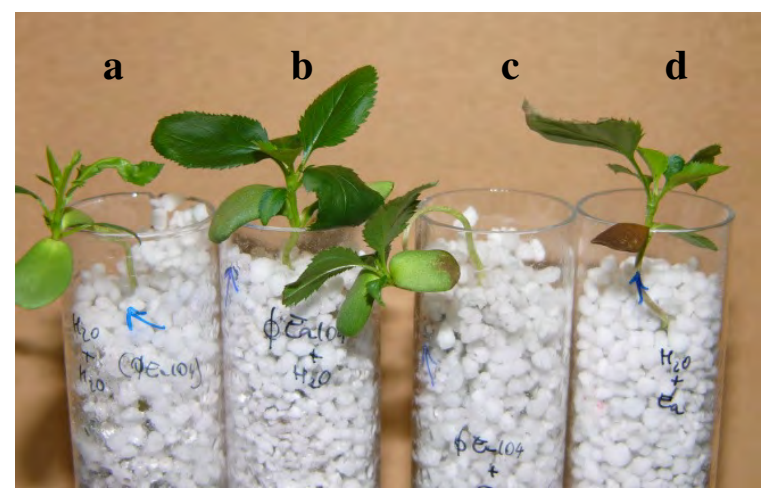

33. ábra Közvetlenül alma csíranövény sziklevelébe irányuló fágkezelés ( $\Phi E a 104,10^{13} \mathrm{PFU} \mathrm{m}^{-1}$ ) hatása az E. amylovora $\left(\mathrm{Ea} 1 / 79 \mathrm{Sm}, 10^{6} \mathrm{CFU} \mathrm{\textrm {ml } ^ { - 1 } )}\right.$ okozta tünetek mértékére öt nappal a kezelés után. (a) $\mathrm{H}_{2} \mathrm{O}+\mathrm{H}_{2} \mathrm{O}$; (b) fág $+\mathrm{H}_{2} \mathrm{O}$; (c) fág+Ea; (d) $\mathrm{H}_{2} \mathrm{O}+\mathrm{Ea}$. 


\section{7 ÚJ TUDOMÁNYOS EREDMÉNYEK}

- Elsőként izoláltunk és jellemeztünk Magyarországon Myoviridae, illetve Podoviridae családba tartozó E. amyovora-specifikus bakteriofágokat.

- Elsőként írtuk le Myoviridae, illetve Podoviridae családba tartozó hét magyar E. amylovora fágizolátum dpo génjének, továbbá egy izolátum peptidázt és két fág $\mathrm{Mu}$ szerü profág proteint, illetve terminázt kódoló régiójának szekvenciáját. E DNS szakaszok nagyfokú homológiát mutattak más E. amylovora fágok ugyanezen DNS szakaszaival, génbanki adatok alapján.

- Új adatokat szolgáltattunk általunk izolált és szelektált bakteriofágok és azok kombinációinak E. amylovora baktérium szaporodását gátló hatásáról, in vitro körülmények között alma- és birsvirágon, éretlen körteszeleten, valamint dísznövényeken.

- Perlites közeg alkalmazásával és a bakteriofágok sziklevélbe injektálásával új módszert dolgoztunk ki annak vizsgálatára, hogy a növények képesek-e gyökéren vagy levélen keresztül felvenni a bakteriofágokat, illetve hogy a növénybe juttatott fágok milyen hatással vannak az E. amylovora okozta tünetekre.

- Elsőként mutattuk ki, hogy az E. amylovora fágok képesek in vitro alma csíranövények gyökerén keresztül felszívódni. 


\section{AZ EREDMÉNYEK MEGVITATÁSA, KÖVETKEZTETÉSEK}

Az általunk Magyarországról izolált E. amylovora fágokat a Caudiovirales renden belül a C1, illetve A1 morfotípusoknak megfelelően a Podoviridae, illetőleg a Myoviridae családokba soroltuk (Ackermann 2007). A hazai izolátumok fejátmérője megfelel az irodalmi adatoknak (Richie és Klos 1979, Müller és mtsai. 2011a); a Podoviridae családba sorolt izolátumok 60 nm, míg a Myoviridae izolátumok $70 \mathrm{~nm}$ körüli fejátmérővel jellemezhetők. A nagyobb méretbeli eltérést ez utóbbi családba tartozó izolátumoknál tapasztaltuk, de ez nem meglepő, mert például a $\Phi E a 21-4$ fág (Lehman és mtsai. 2009) az ismert amerikai fágtörzsekhez képest szintén kisebb méretü fejrésszel rendelkezik.

A fágizolátumok által tesztbaktériumon képzett tarfoltok morfológiája a fágok egyik jellemzője, melyet - többek között - Gill és mtsai. (2003) is részletesen vizsgáltak. Hazai fágizolátumaink igen eltérő, 0,5 - 7,1 mm mérettartományon belüli átmérőjű plakkokat adtak a tesztbaktériumot tartalmazó fedőagar rétegen, és a tarfoltokat övező sáv - megléte esetén - 0,15,0 mm közötti átmérőjü volt a különböző fágizolátumoknál. A $\Phi E a 1 h$ mérete megegyezett a Richie és Klos (1979) által leírtakkal. Az amerikai bakteriofágok közül a $\Phi E a 100$-as törzs képezte a legnagyobb átmérőjü és sávval övezett plakkokat, melyhez képest az egyik legnagyobb méretű plakkot képző magyar fágizolátum (H7B) szélesebb plakk-sávot ad, mely a fág erőteljesebb lizálóképességére utal.

Molekuláris vizsgálatainkban az alkalmazott indító szekvenciákkal végzett PCR reakciók eredménye alapján megállapítható, hogy fágizolátumaink különböznek a tesztelt amerikai fágtörzsektől. Izolátumainkban az EPS depolimeráz, holin, lizozim, termináz, peptidáz, Muszerü profág protein, valamint a kapszid enzimeket kódoló gének bázissorrendjét vizsgáltuk, azért, mert ezek esetében bizonyított a fágokban betöltött szerepük (Kim és Geider 2000, Lehman és mtsai. 2009, Müller 2011a) és ismert mely DNS szakaszok kódolják szintézisüket. Mivel a fágok hatékonysági vizsgálataiban a H2A és a H5K bizonyultak az egyik legjobbaknak, és mert ezek szekvenciái még nem ismertek, olyan genetikai markereket kerestünk, amelyekkel e fágok később jellemezhetők vagy esetleg azonosíthatók lesznek. A részleges szekvencia-analízis fényt derített arra, hogy a H2A és a H5K genomjában egyaránt fellelhető az úgynevezett nagy termináz alegységet, valamint a Mu-szerü profág proteint kódoló génszakasz, melyek nagyfokú hasonlóságot mutatnak a vB_EamM-M7 E. amylovora fággal (Born és mtsai. 2011). Mivel a H2A izolátum peptidázt kódoló régiója is 99\%-ban ezzel a fágtörzzsel egyezik, a további vizsgálatainkat a vB_EamM-M7 fágra is tervezzük kiterjeszteni. 
Tekintettel arra, hogy a ФEaH2 törzs (GenBank-i leltári szám: JX316028) jelentősen eltér az eddig ismert E. amylovora fágoktól és egyúttal egy hazai fágizolátum, fontosnak tartottuk, hogy genomját a saját, magyarországi fágizolátumainkkal összehasonlítsuk, különös tekintettel egy meghatározott DNS szakaszra, amely a Dömötör és mtsai. (2012) által izolált fágban benne van, és ami nagyfokú homológiát mutat az E. amylovora baktérium virulenciájában jelentős szerepet játszó amilovoran bioszintéziséhez szükséges fehérjét kódoló amsF génnel. A szerzők e gén jelenléte miatt megfontolandónak tartják az általuk izolált törzs biológiai védekezésben való alkalmazását. A $\Phi E a H 2$ fág erre a DNS szakaszára tervezett primer párra (phiEaH2-F/R) valamennyi tesztelt fágizolátumunk negatív lett, azonban a baktérium ams $\mathrm{F}$ génjére specifikus primerekre $(\mathrm{EaFF} / \mathrm{R})$ a H9A kivételével mindegyik fág pozitívnak bizonyult. Ugyanakkor a negatív kontrollként használt minta, a $\Phi E a 1 h$ is gyengén pozitív lett, ezért felmerült a kontamináció lehetősége. A baktérium-szennyeződés kizárása érdekében tervezzük, hogy az eredeti vad fág törzseket amilovorant nem termelő baktériumtörzsben szaporítjuk fel, majd ezt követően ellenőrizzük e DNS szakasz jelenlétét és szekvenciáját. Vizsgálataink ideje alatt a nemzetközi gén adatbázisokból hozzáférhetővé váltak egy újabb magyar $E$. amylovora fág (ФEaH1) teljes genomjának szekvencia adatai is (NC_023610 Meczker és mtsai. 2014), így további vizsgálatainkba ezt a fágtörzset is tervezzük bevonni.

A PCR vizsgálatok eredményei és a tesztelt fágok plakkmorfológiája közötti összefüggések tekintetében elmondható, hogy a PCR eredmények alapján legegységesebb, zölddel jelölt csoport tagjai (H1A, H1B, H2A, H2B, H10A, H10B, H11, H12A) dpo-negatívak

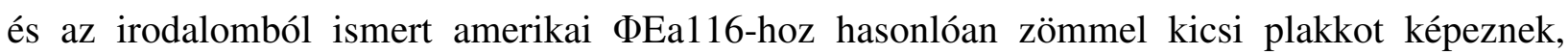
melyeket nem, vagy csak egy nagyon keskeny sáv övez. Ez a tendencia figyelhető meg a más csoportokba tartozó, de ugyancsak depolimerázt nem kódoló genomú H5K, valamint a H8A és a H9A izolátumok esetében. Érdekes ugyanakkor, hogy a szintén dpo-negatívnak bizonyult H8B nagy plakkal jellemezhető. A dpo-pozitív izolátumok közül kerülnek ki a gazdabaktériumgyepen legnagyobb tarfoltot képező, egy csoportba sorolt H6B és H9B fágizolátumok.

Hazai fágizolátumaink különböző E. amylovora izolátumokra, Erwinia, Pantoea és más baktériumfajokra gyakorolt hatását tesztelve azt találtuk, hogy a magyar fágok a vizsgálatban szereplő amerikai fágtörzsekhez képest szélesebb gazdakörrel rendelkeznek. Hasonló vizsgálatokat Gill és mtsai. (2003), valamint Müller és mtsai. (2011a) is végeztek, akik szintén jelentős különbségeket tapasztaltak az egyes E. amylovora fágok gazdakörét tekintve. Kísérleteinkben a tesztelt izolátumok közül hat (H1B, H2A, H2B, H4A, H7A, H7B) bizonyult kifejezetten Erwinia-specifikusnak, mivel ezek, az E. tasmaniensis kivételével lizálták az összes többi vizsgált Erwinia izolátumot és törzset, ugyanakkor a H2B és a H7B kivételével, melyek lizálták a Pseudomonas syringae pv. syringae H9-es törzset is, nem lizáltak más, az Erwinia-val 
nem közeli rokon patogén baktériumot. Eredményeink részben megegyeznek a Müller és mtsai. (2011a) által közöltekkel. Az egyes tesztbaktériumoknak a gazdakörvizsgálatok részeként feltárt eltérő fágérzékenysége lehetőséget teremt a fágok szaporodását biztosító, s ezáltal az adott növényvédelmi célú fágkezelések hatékonyságát potenciálisan növelő, nem patogén baktériumtörzsek kiválasztásához. Esetünkben a Pantoea agglomerans MB96 volt a legfogékonyabb a vizsgált fágokkal szemben; a H4B kivételével valamennyi fág tiszta plakkokat képzett rajta, ugyanakkor az antagonista E. billingae Eb661 törzs is perspektivikus lehet e szempontból. Jellemzően ugyanazon baktériumok eltérő mértékben lehetnek fogékonyak az egyes fágokra; Müller és mtsai. (2011a) által tesztelt németországi fágizolátumok például csak gyengén lizálták az E. billingae Eb661 baktériumtörzset, mely így nem szolgálná hatékonyan azok felszaporítását. Különböző E. amylovora izolátumok néhány általunk izolált fággal szembeni fogékonyságáról már korábban Végh (2012), valamint Végh és mtsai. (2012c) is beszámoltak.

Az E. amylovora fágok tüzelhalással szemben kifejtett hatását először folyadékkultúrában teszteltük. A fág és a kórokozó szuszpenzióját tartalmazó tápoldatban az inkubációs idő végére lecsökkent optikai sürüség értékeket mértünk, hasonlóan Schnabel és Jones (2001) kísérletéhez. Ismerve azt, hogy a fágok kombinációban alkalmazva hatékonyabbak lehetnek, mint önállóan (Schnabel és mtsai. 1999, Svircev és mtsai. 2010), a három legeredményesebb fágizolátumot különböző kombinációkban is tesztelve a $\mathrm{H} 2 \mathrm{~A}+\mathrm{H} 5 \mathrm{~K}+\mathrm{H} 7 \mathrm{~B}$ fágkoktél bizonyult a legjobbnak. Az E. amylovora szaporodását folyadékkultúrában legjobban gátló izolátumokat és hármas kombinációjukat alma- és birsvirágokon in vitro tesztelve azt tapasztaltuk, hogy mindegyik vizsgált almafajta és a birs esetén a fágos kezelések visszaszorították az E. amylovora szaporodását. Az egyik legeredményesebb kezelést a fágkombináció adta, mely szignifikánsan hatékonyabbnak bizonyult a mérsékelten rezisztens 'Pinova' fajtán a fogékonynak számító 'Idared' fajtához képest. Müller és mtsai. (2011a) ezzel ellentétben azt figyelték meg, hogy a kombinációban adott fágkezelések nem voltak szignifikánsan hatékonyabbak annál, mint amikor az adott fágot önmagában juttatták ki alma virágokra, illetve körteszeletekre. Körte fajták éretlen gyümölcsszeletein vizsgálva a virágkísérletek során is tesztelt fágizolátumok és hármas kombinációjuk baktérium-visszaszorító hatását megállapíthattuk, hogy a fágkezelések mérsékelték a tüneteket a pozitív kontrollhoz képest és hatásuk, a legtöbb esetben a 'Dr. Guyot Gyula' fajtán volt szignifikáns. Azonban a körteszeletekre alkalmazott kezelések kevésbé voltak hatásosak, mint a virágokon; hasonlóan Müller és mtsai. (2011a) megfigyeléseihez. 
A H2A, H4A és H5A fágizolátumok és azok kombinációját dísznövényeken tesztelve a virágfertőzöttség mértéke alapján a tűztövis és a kerti madárbirs virágai mérsékelten rezisztenseknek bizonyultak az E. amylovora-ra a házi berkenye és az egybibés galagonya virágaihoz képest, továbbá az is megfigyelhető volt, hogy ezeknél, a kísérletünkben kevésbé fogékonyan szereplő növényfajoknál voltak hatékonyabbak a fágkezelések. Érdekes, ugyanakkor nem meglepő ez az eredmény, mert habár a Cotoneaster fajok tüzelhalásra fogékonyként szerepelnek az irodalomban - az adatok főként hajtásfertőzöttségre vonatkoznak (Lecomte és Cadic 1993) - és náluk kevésbé fogékonynak tekintik a Pyracantha nemzetséget, a Crataegus-ok változó fogékonyságáról számoltak be (Lespinasse és Aldwinckle 2000).

Noha az alma- és birsvirágokon, körtegyümölcs-szeleteken, valamint a fenti dísznövények virágain végzett kísérletek eredményei alapján nem vonható le egyértelmü következtetés a tekintetben, hogy az egyes növényfajoknak, illetve fajtáknak az E. amylovora okozta fertőzésre való eltérő fogékonysága és a fágkezelések hatékonysága között szoros összefüggés áll fenn, mégis valószínűsíthető, hogy az ellenállóbbnak tekintett fajok, fajták esetében hatékonyabban működnek az alkalmazott fágok. Ezt támasztják alá Schwarczinger és mtsai. (2011) eredményei, akik magyar E. amylovora fágizolátumok baktérium-elimináló hatását eltérő fogékonyságú almafajták virágain vizsgálva azt tapasztalták, hogy az általuk tesztelt fágizolátumok igen hatékonyan gátolták az E. amylovora szaporodását alma virágokon, különösen a tüzelhalásra rezisztens 'Freedom' fajta (G. Tóth 1997) esetében. Ugyanakkor elképzelhető, hogy Schwarczinger és mtsai. (2011) azért kaptak ilyen eredményt, mert a fágos kezelést és a baktériummal történő mesterséges inokulációt nem egyidőben végezték - ahogy azt mi tettük - hanem külön-külön, vagyis a baktérium-szuszpenzió bibére cseppentését megelőzte a virágok fággal történő permetezése. Későbbi eredményeinkből feltételezhető, hogy ez a kezelési mód kedvezőbb a fág számára, mert a fágnak van ideje „felszívódni” és a növény belsejébe jutni, így ott is ki tudja fejteni baktériumölő hatását. A fajták fogékonyságának megítélése mindazonáltal nem egyszerü, mert ismeretes, hogy egy adott fajta egyes vizsgált növényi részei (hajtás, virág, gyümölcs) eltérő fogékonyságot mutathatnak (Honty 2011, Paulin és mtsai. 1990), sőt ugyanaz a vizsgált szerv is képes a különböző években eltérő módon reagálni az $E$. amylovora okozta fertőzésre (Honty 2011). Honty (2011) eredményei alapján például a 'Conference' és a 'Dr. Guyot Gyula'éretlen gyümölcseit a nagyon fogékony, virágait az igen erősen fogékony kategóriákba sorolta, míg az 'Erdei vajkörte', éretlen gyümölcseinek relatív tüzelhalás fogékonysága alapján nagyon fogékonynak, ellenben virágfertőzésre mérsékelten rezisztensnek bizonyult.

A fágkezelés hatékonyságának potenciális növelése céljából úgynevezett transzlokációs kísérletekkel tisztázni kívántuk, hogy alma növények gyökérzónájához, illetve a föld feletti 
növényi részeire kijuttatott $E$. amylovora-specifikus bakteriofágok képesek-e a növénybe jutni, majd ott szisztemikusan elterjedni, valamint, hogy az in planta transzlokálódott fágok milyen hatást gyakorolnak egy E. amylovora infekcióra. Alma csíranövényeken végzett kísérleteinkben kimutattuk, hogy mindkét általunk tesztelt E. amylovora-specifikus fág (H5K és ФEa104) az adott körülmények között képes volt penetrálódni és a növény távolabbi részeibe elszállítódni, ahogy az más bakteriofág-növény kapcsolat esetében már korábban igazolást nyert (Rao és Srivastava 1973, Ward és Mahler 1982, Iriarte és mtsai. 2012). Tudomásunk szerint jelen munkánkkal elsőként számolunk be E. amylovora-specifikus fágok gyökéren keresztül való növénybe jutásáról, valamint az így transzlokálódott fágoknak a kórokozó okozta tünetek mérséklésében játszott szerepéről, mely hatást almafák lombozatára kijuttatott E. amylovora fágok esetében Dömötör és mtsai. (2012) is kimutatták. Kísérleteinkkel feltártuk továbbá, hogy a H5K fágok életképességüket a gazdabaktérium jelenléte nélkül öt napig is meg tudták őrizni a növényben. Ez megfelel annak, ami Ralstonia solanacearum (ФRS5) fágok vonatkozásában ismert (Iriarte és mtsai. 2012), nevezetesen, hogy ezek a fágok a gazdabaktériumuk nélkül legalább 3-5 napig életképesek maradtak paradicsom növények szárában és levelében. Ugyanakkor a fágok akár hosszabb ideig is fennmaradhatnak a növényben, tekintetbe véve, hogy bizonyos Xanthomonas-specifikus fágok a kijuttatásukat követően 7-15 napig életképesek maradtak a tesztnövényekben (Iriarte és mtsai. 2012), míg Agrobacterium tumefaciens PB2-A fágok 14 napig megőrizték életképességüket paradicsom növények gyökerében és szárában (Boyd és mtsai. 1971). A fágok in planta szállítódásának vizsgálatában mindkét általunk használt fág kimutatható volt az alma növények felső, leveles részéből és a gyökérzetből is és a legtöbb esetben a kezelést követő első napon detektáltunk fágokat az adott növényi mintákból. Ennek a kísérletnek az alapján elmondható, hogy az amerikai származású $\Phi E a 104$ gyorsabban és biztosabban szállítódhat a növényben, mint a magyar H5K fágizolátum, viszont a két kezelési mód hatékonysága nem volt összemérhető, mivel a különböző fágok esetén eltérő eredményt kaptunk. Ugyanakkor megállapíthattuk, hogy a transzlokálódott fágok titere gyorsan csökkent; a kezelést követő hetedik napon vett minták egyikéböl sem tudtunk már fágokat kimutatni. Ismeretes, hogy a fágok növény általi felvétele és szállítódása nagymértékben függ többek között a termesztő közeg abszorpciós képességétől (Oron és mtsai. 1995) és az adott növény meghatározott sajátosságaitól, úgymint a korától, kondíciójától vagy potenciális védekezési mechanizmusaitól (Ward és Mahler 1982, Iriarte és mtsai. 2012). Ismert továbbá, hogy a fitopatogén vírusok növényen belüli mozgásának mértéke függ a virális fehérjéknek a növényi citoszkeletonnal, valamint a különböző típusú plazmodezmákkal kialakított kölcsönhatásaitól és a vírusok különböző növényi sejtekben mutatott szaporodási (replikációs) képességétől is (Astier és mtsai. 2007). Ez utóbbi szerzők azt is állítják, hogy a különböző típusú növényi 
szövetek sejtjei között helyet foglaló plamodezmák is gátolhatják a növényi vírusok mozgását. Mindezek arra a feltételezésre adnak okot, hogy hasonló jelenségek akadályozhatják a bakteriofágok, azaz a baktériumok vírusainak in planta terjedését. Ugyanakkor nem zárhatjuk ki a fágok növénybe jutását és rövid távú transzlokációját, mert azokban a növényi részekben, ahová a fágkezelést alkalmaztuk nem vizsgáltuk a fágok jelenlétét. Ezt abból a célból tettük, hogy elkerüljük azokat a téves eredményeket, melyek a fágok kijuttatási helyénél a növény felszínén maradó fágok detektálásából származhattak volna. Noha Rao és Srivastava (1973) kimutatták, hogy Xanthomonas orizae $\mathrm{XOP}_{10}$ fágok képesek rizs palánták gyökerén át a növénybe hatolni függetlenül attól, hogy a gyökérzet ép, vagy sérült volt a fágkezelést megelőzően, elképzelhető, hogy intakt gyökéren keresztül kisebb mértékü a fágok penetrációja. Ezt a feltételezést támasztja alá Ward és Mahler (1982) kutatásainak eredménye, mely arról számolt be, hogy az E. coli f2 fág (Loeb és Zinder 1961) növény általi felvételének mértéke hidropóniás kultúrában nevelt kukorica és bab palánták visszavágott gyökerén keresztül lényegesen nagyobb volt ahhoz képest, amit sértetlen gyökerü növények esetében tapasztaltak a növények szárából, illetve leveléből visszaizolált életképes fágok mennyiségének meghatározása alapján. Ezek azonban eltérnek Iriarte és mtsai. (2012) eredményeitől, akik paradicsompalánták felső szárrészébe és ottani leveleibe transzlokálódott Xanthomonas-specifikus fágok szintjének gyorsabb csökkenését figyelték meg abban az esetben, amikor a gyökeret előzőleg megsértették. A különböző fágkezelések tűzelhalás tüneteire gyakorolt hatásának tekintetében a szimptómák szignifikáns csökkenését tapasztaltuk a kezeletlen kontrollokhoz képest akár a gyökérzethez vagy a levélzetre jutattuk ki a fágokat, akár az alma csíranövények sziklevelét injektáltuk vagy a virágzó tüztövis vesszőket kezeltük a fágokkal az E. amylovora inokulációt megelőzően. Azonban a H5K izolátum és a $\Phi$ Ea104 fágtörzs hatékonysága között nem találtunk szignifikáns eltérést. Mindazonáltal eredményeink összhangban állnak azzal, amiről Kovács és mtsai. (2012) számoltak be; a szerzők szabadföldi kísérleteikben kimutatták, hogy egy specifikus fágkombináció almafákra permetezve jelentős mértékben lecsökkentette a természetes $E$. amylovora fertőzés következtében megjelenő, tüzelhalás tüneteit mutató növényi részek számát.

A fágok transzlokációjának vizsgálatakor használt módszerünk újszerüsége abban rejlik, hogy a többi, irodalomból ismert módszerrel ellentétben - ahol termőföldet (Iriarte és mtsai. 2012), vagy vizet (Ward és Mahler 1982) használtak - mi perlitet alkalmaztunk ültetési közegként, illetve, hogy tudomásunk szerint először vizsgáltuk fágok hatását baktériumok okozta tünetekre úgy, hogy a fágokat a sziklevélbe injektáltuk a mesterséges inokulációt megelőzően. A szakirodalomból ismert hasonló vizsgálatokban a fágot, vagy a gyökéren keresztül (Iriarte és mtsai. 2012), vagy a növényre permetezve (Kovács és mtsai. 2012) juttatták a növénybe. A szakirodalomból és korábbi előkísérleteinkből is ismert a fágok abszorpciója a talajkolloidokhoz 
(Oron és mtsai. 1995), ezzel szemben a perlitnél a talajban nevelt növényekhez hasonló mértékü fágkoncentráció csökkenést nem tapasztaltunk. Az injektálás előnye a permetezéssel vagy a beöntözéssel szemben az, hogy ezáltal adott mennyiségü fág hatását tudjuk direkt módon vizsgálni a növényben anélkül, hogy a kezelés során jelentős fágkoncentráció csökkenéssel kéne számolnunk. Továbbá ennek köszönhetően steril körülmények között, más mikroorganizmusok „fág-szállítóként” való kizárásával tudjuk e folyamatokat megfigyelni. 


\section{7 ÖSSZEFOGLALÁS}

Az almatermésűek tűzelhalása a Rosaceae családba tartozó növények egy részének régtől ismert egyik legjelentősebb bakteriális eredetü betegsége. Kórokozója az Erwinia amylovora (Burrill) Winslow et al. (1920) növénypatogén baktérium, mely a számára optimális időjárási feltételek esetén nagymértékü gazdasági károkat képes előidézni alma-, körte- és birsültetvényekben, valamint fogékony dísznövényeken. Az Amerikai Egyesült Államokban honos, hazánkban karantén kórokozó az 1950-es évek közepén jelent meg először Európában, Magyarországon 1995-ben azonosították elsőként egy Nyárlőrinc térségében levő alma ültetvényböl.

Jelenleg e betegség elleni védekezés - az eddigi legeredményesebb védekezési módnak, a virágzáskori sztreptomicin antibiotikummal végzett kezelésnek a betiltása óta - nem megoldott. A tiltó rendelkezés azonban, mely több ország mellett hazánkban is érvényben van, számos alternatív védekezési stratégia kutatásához vezetett, melyek egyike a bakteriofágok használatára épül.

Munkánk során célul tüztük ki E. amylovora-specifikus bakteriofágok magyarországi gyüjtését, az izolátumok jellemzését, a kórokozó elleni leghatékonyabb fágizolátumoknak a baktérium szaporodására gyakorolt gátló hatásának in vitro vizsgálatát, továbbá ezen fágok növénybe jutásának és a növényen belüli szállítódásának tisztázását és a növénybe juttatott fágok E. amylovora fertőzésre gyakorolt hatásának vizsgálatát a betegség elleni biológiai védekezésben való felhasználásuk lehetősége céljából.

Elsőként izoláltunk Magyarországról Myoviridae, illetve Podoviridae családba tartozó E. amylovora bakteriofágokat. Az általunk izolált fágokat több szempontból is jellemeztük és vizsgálatainkhoz a szakirodalomból már jól ismert, széleskörüen jellemzett, az Amerikai Egyesült Államok területéről származó E. amylovora fágtörzseket használtunk referenciatörzsként. A fágizolátumok közül 22-t jellemeztünk az Adams-féle dupla agar módszerrel plakk morfológiájuk, 19 izolátumot transzmissziós elektronmikroszkópos vizsgálattal partikulum morfológiájuk, 21-et PCR technikával, 9 izolátumot részleges szekvencia-analízissel és 16 fágizolátumot gazdakörük alapján.

Izolátumaink eltérő méretű, 0,5 - 7,1 mm átméröjü plakkokat formáltak a tesztbaktériumot tartalmazó lágyagar rétegen. Közülük az egyik legnagyobb tarfoltja a H7B jelzésű fágnak van, melynek plakkja körül szélesebb sáv húzódik, mint a vizsgálatunkban szereplő legnagyobb plakkot adó amerikai $\Phi E a 100$ törzs esetében, ami a H7B nagyobb lítikus enzimaktivitását jelzi. Fágizolátumaink többsége (15) az elektronmikroszkópos vizsgálat eredménye alapján ikozaéder 
alakú fejjel és hosszú, összehúzódó farki résszel rendelkezik (Myoviridae), míg kisebb hányadára (4) kisebb, izometrikus fej és rövid, széles farki rész jellemző (Podoviridae). Hazai izolátumaink eltérnek a Siphoviridae családba tartozó, irodalomból ismert két másik magyar fágtörzstől (ФЕaH1, ФЕaH2).

PCR vizsgálataink alapján megállapítottuk, hogy magyar fágizolátumaink, melyeket négy nagyobb csoportba soroltunk, nem azonosak a vizsgálatokba bevont 4 amerikai E. amylovora fággal.

Meghatározott fágizolátumaink részleges szekvencia-analízise alapján megállapítottuk, hogy a H4A, H4B, H5A, H5B, H6A, H7A és H9B jelzésü fágok depolimeráz génjének bázissorrendje 98-99\%-ban megegyezik a $\Phi E a 1 h$ amerikai fágtörzs depolimeráz génje megfelelő szakaszának bázissorrendjével. A H2A fág peptidázt, valamint a H2A és a H5K fág Mu-szerü proteint, illetve terminázt kódoló régiói pedig a vB_EamM-M7 fág adott DNS szakaszaival mutatnak nagyfokú, 99\%-os hasonlóságot.

Az általunk izolált fágok gazdakörvizsgálata fényt derített arra, hogy a kísérletben szereplő amerikai fágtörzsekhez képest szélesebb gazdakörrel rendelkeznek. Izolátumaink közül a H1B, H2A, H2B, H4A, H7A és H7B jelzésủek lizálták a legtöbb tesztelt baktérium-izolátumot, illetve törzset, ugyanakkor a hazai E. amylovora izolátumok mindegyike fogékony volt a fágizolátumokkal szemben függetlenül azok származásától.

Hazai fágizolátumaink hatékonyságát először folyadékkultúrában teszteltük, majd a leghatékonyabbnak bizonyult $\mathrm{H} 2 \mathrm{~A}, \mathrm{H} 5 \mathrm{~K}$ és $\mathrm{H} 7 \mathrm{~B}$ fágnak és azok kombinációinak az $E$. amylovora baktérium szaporodását gátló hatását vizsgáltuk in vitro körülmények között, eltérő fogékonyságú termesztett alma- és birsvirágokon, éretlen körtegyümölcs szeleteken. A H2A, H4A és H5A fágizolátumok és azok kombinációja pedig dísznövényeken lett tesztelve.

Alma- és birsvirágokon végzett kísérleteinkben, mindkét ismétlésben valamennyi vizsgált almafajta ('Gala', 'Golden delicious Reinders', 'Idared', 'Pinova') és a birs ('Berecki') esetén a fággal végzett kezelések csökkentették a visszaizolált baktériumok számát. Az első kísérletben a 'Golden delicious Reinders' virágainak a H5K fággal történő kezelését kivéve valamennyi tesztnövényen mindegyik fágkezelés szignifikánsan hatékonyabb volt az erviniás kontrollhoz képest. A 'Gala Schniga', a 'Pinova' és a 'Berecki' fajták esetében a legjobb hatást nyújtó fágkombináció a 'Gala Schniga' és a 'Pinova' fajtákon a többi fajtához képest is szignifikánsan hatékonyabbnak bizonyult. A második ismétlésben a H2A, a H7B fág és a fágkombináció az 'Idared' és a birs kivételével mindegyik tesztnövényen szignifikánsan hatékonyabb volt az erviniás kontrollhoz viszonyítva. A fágkombináció legeredményesebb a 'Golden delicious Reinders' almafajta virágain volt, míg a fajták közötti hatékonyságát tekintve a 'Pinova' virágokon szignifikánsan visszaszorította a baktériumok számát az 'Idared' fajtán mértekhez 
képest. Eredményeinkből kitünik, hogy mindkét évben az egyik leghatékonyabb kezelést a fágkombináció jelentette, mely szignifikánsan eredményesebb volt a mérsékelten rezisztens 'Pinova' fajtán a fogékonynak számító 'Idared' fajtához képest. A telepszámlálással nyert eredményeink ('Idared' fajta, 2012) kvantitatív PCR technikával is megerősítést nyertek.

Körtefajták zöld gyümölcsszeletein vizsgálva a virágkísérletek során is tesztelt fágizolátumok és hármas kombinációjuk baktérium-visszaszorító hatását megállapítottuk, hogy a fágok csökkentették a tüneteket a pozitív kontrollhoz képest. Az első kísérletben a H5K és a fágkombináció szignifikánsan hatékonyabb volt az erviniás kontrollhoz képest mindhárom fajta esetén. A kezelések fajták közötti összefüggéseinek a vizsgálatából az derült ki, hogy a 'Dr. Guyot Gyula' és az 'Erdei vajkörte' szeleteken szignifikánsan mérsékeltebben jelentkeztek az erviniás fertőzés következtében kialakuló tünetek a 'Conference' fajtához képest valamennyi fágos kezelés esetén. A kísérlet ismétlésében a 'Dr. Guyot Gyula' fajtán valamennyi kezelés szignifikánsan lecsökkentette a tüzelhalás tüneteit a pozitív kontrollhoz képest. Ez a hatás az 'Erdei vajkörte' esetében csak a H2A, míg a 'Conference' fajtánál a H5K és a fágkombináció alkalmazásakor igazolódott. A fágos kezelések fajták közötti hatását összehasonlítva megállapítást nyert, hogy a H2A és a H5K fágkezelés hatására szignifikánsan lecsökkentek az erviniás tünetek a 'Dr. Guyot Gyula' és az 'Erdei vajkörte' fajtákon a 'Conference' fajtához képest. Az egyes fágos kezelések hatékonysága között a H2A fágnak a H7B fágtól való eltérését kivéve nem volt szignifikáns különbség. A fágok baktérium-elimináló hatása ellenben messze elmaradt a sztreptomicin-szulfátétól valamennyi kísérletben. Az eredmények alapján az adott fágkezelések hatékonyabbnak bizonyultak az 'Erdei vajkörte' és a 'Dr. Guyot Gyula' fajtán a 'Conference' fajtához képest.

Tüzelhalásra fogékony négy dísznövényfaj virágain vizsgálva a H2A, a H4A és a H5A fágizolátum hatását a fágkoktél alkalmazása bizonyult a legeredményesebbnek. Az E. amylovora inokuláció következményeként kialakuló szimptómák mérséklésében a leghatékonyabb kezelést a tüztövis virágokra kijuttatott fágkombináció jelentette, míg a berkenyén és a galagonyán a fágkoktél nem csökkentette le jelentős mértékben a virágnekrózis mértékét.

A tủzelhalás elleni bakteriofág-alapú biológiai védekezési mód hatékonyságának potenciális fokozása céljából vizsgáltuk fágok növénybe jutását és a növényen belüli szállítódását steril körülmények között. Vizsgálatainkhoz egy amerikai fágtörzset (ФEa104) és egy általunk izolált magyar fágizolátumot (H5K) használtunk. Megállapítottuk, hogy (1) a H5K fágjai képesek voltak a gyökérzeten át az alma csírnanövények felső részébe szállítódni, továbbá életképességüket a gazdabaktérium jelenléte nélkül hat napig is megőrizni, ugyanakkor titerük jelentősen lecsökkent. (2) A H5K és a $\Phi E a 104$ esetében egyaránt, a gyökérzónához történő kijuttatásuk után a növény föld feletti részeiből, a szárra és a levélzetre való kipermetezésüket 
követően pedig a gyökérzetből úgyszintén sikerült detektálni a fágokat, legtöbbször a kezelést követő első mintavételi napon, de hét nappal a kezelés után már egyik mintából sem. A két fág közötti eltérés abban nyilvánult meg, hogy az amerikai fágot több esetben lehetett kimutatni, ugyanakkor rövidebb ideig volt detektálható, mint a H5K izolátum. A fágoknak (H5K és ФEa104) az E. amylovora mesterséges fertőzés következtében kialakuló tünetekre gyakorolt hatását vizsgálva megállapítottuk, hogy (3) alma csíranövények gyökérzónájához, illetve a növény föld feletti részeire juttatva ki a fágokat a fágkezelés hatására mindkét kijuttatási mód esetén szignifikánsan lecsökkent a tüzelhalás tünetek mértéke a kezeletlen kontrollhoz képest. (4) A fágokat alma csíranövények egyik sziklevelébe juttatva, majd közvetlenül utána inokulálva a tesztnövényt, az így elvégzett fágkezeléseket követően a baktérium által előidézett tünetek mértéke szignifikánsan lecsökkent a kezeletlen kontrollhoz képest. A két fág hatékonysága között azonban egyik kísérletnél sem volt szignifikáns a különbség. Megállapítottuk tehát, hogy az általunk vizsgált E. amylovora-specifikus fágok bizonyos körülmények között képesek a tesztnövények gyökerén és lombozatán keresztül a növénybe hatolni, majd a növényben szétterjedve csökkenteni e fitopatogén baktérium által okozott tünetek mértékét.

Az általunk izolált új fágok, illetve azok kombinációi, valamint e fágok in planta transzlokációs képességére vonatkozó új ismeretek reményeink szerint teret nyitnak azoknak a további vizsgálatoknak, amelyek elösegíthetik a bakteriofágok hatékonyabb felhasználását a tüzelhalás elleni védekezésben. 


\section{SUMMARY}

Fire blight of pome fruits is one of the most important and longest-known bacterial disease of plants in the rose family (Rosaceae). It is caused by the phytopathogenic bacterium Erwinia amylovora (Burrill) Winslow et al. which is able to induce huge economic losses in apple-, pearand quince orchards under weather conditions optimal for its growth. The pathogen, being native to North America and regarded as a quarantine organism in Hungary, first appeared in Europe in the 1950s. In Hungary it was first found in a Nyárlörinc apple orchard in 1995.

Currently, the control of this disease is questionable since the most effective means of protection, the timed application of the antibiotic sztreptomicin to open blossoms is not allowed. However, this injunction ruling in many countries including Hungary led to the research of numerous alternative control strategies one of which is based on the application of bacteriophages. We aimed (1) to collect and isolate E. amylovora-specific phages from Hungary, (2) to characterize them, and (3) to study in vitro the impeding effect of the most effective phage isolates on growth of E. amylovora. Furthemore, our intention was to (4) clarify the uptake and delivery of these phages in plants, and to investigate the effect of phages introduced into the plant on the infection of E. amylovora to survey the possibility of their use in biological control against the disease.

We have isolated E. amylovora-specific bacteriophages belonging to the Myoviridae and Podoviridae families from Hungary for the first time. We have characterized these phage isolates in several aspects using well-known, extensively featured E. amylovora-specific phage strains originating from North America as reference. Out of our phage isolates we have characterized 22 by their plaque morphology with the Adams's double layer method, 19 isolates by their particle morphology with transmission electron microscopy, 21 by PCR, 9 isolates by partial sequence analysis and 16 phage isolates based on their host range.

Our isolates formed different size plaques varying between $0.5-7.1 \mathrm{~mm}$ in diameter on the soft agar layer containing test bacteria. One of the largest plaques are produced by the phage $\mathrm{H7B}$, the plaques of which are surrounded by a wider halo as compared to the phage strain ФEa100 that forms the largest plaques among the tested American strains. This indicates the higher lytic activity of H7B.

Based on the results of transmission electron microscopy most of our phage isolates (15) have an icosahedral head capsule and a long, contractile tail (Myoviridae), while only a few isolates (4) feature a smaller isometric head and a short, broad tail (Podoviridae). Our isolates 
differ from the two Hungarian phage strains $(\Phi \mathrm{EaH} 1, \Phi \mathrm{EaH} 2)$ known from the literature, which belong to the Siphoviridae.

Based on PCR tests we have found that our Hungarian phage isolates can be classified into 4 larger groups. Furthermore, these isolates are not identical to the tested four American $E$. amylovora-specific phages.

Partially sequencing some of our phage isolates (H4A, H4B, H5A, H5B, H6A, H7A, H9B) we have determined that the nucleotide sequences of their depolimerase gene match the appropriate section of those of the American phage strain $\Phi E a 1 \mathrm{~h}$ in 98-99\%. The regions coding for peptidase in the genome of $\mathrm{H} 2 \mathrm{~A}$, and for terminase and $\mathrm{Mu}$-like prophage protein of $\mathrm{H} 2 \mathrm{~A}$ and H5K display a high, 99\% similarity with the corresponding DNA sequences of the vB_EamM-M7 phage strain.

Host range studies revealed that our Hungarian phage isolates possess a broader host range compared to the tested American phage strains. Out of our isolates H1B, H2A, H2B, H4A, H7A and $\mathrm{H} 7 \mathrm{~B}$ lysed the highest number of tested bacterial isolates and strains, while all of the domestic E. amylovora isolates were sensitive to the phage isolates irrespectively of their origin.

We have tested the effectiveness of our Hungarian phage isolates first in liquid bacterial culture, then we have studied in vitro the impeding effect of the most effective $\mathrm{H} 2 \mathrm{~A}, \mathrm{H} 5 \mathrm{~K}$ and $\mathrm{H} 7 \mathrm{~B}$ phages and their combinations on the growth of $E$. amylovora on apple and quince blossoms and on immature pear slices that display different sensitivity to fire blight. Phage isolates $\mathrm{H} 2 \mathrm{~A}, \mathrm{H} 4 \mathrm{~A}, \mathrm{H} 5 \mathrm{~A}$ and their combination were tested on ornamental plants.

In the experiments carried out on apple and quince blossoms phage treatments confined the growth of E. amylovora in case of all apple ('Gala', 'Golden delicious Reinders', 'Idared', 'Pinova') and quince ('Berecki') varieties in both replicates. In the first experiment all phage treatments were significantly more effective than the $E$. amylovora control on all of the test plants except the treatment of 'Golden delicious Reinders' flowers with the phage H5K. In case of 'Gala Schniga', 'Pinova' and 'Berecki' the phage combination provided the best protection effect and proved to be significantly more effective on flowers of 'Gala Schniga' and 'Pinova' compared to the other varieties. In the second experiment $\mathrm{H} 2 \mathrm{~A}, \mathrm{H} 7 \mathrm{~B}$ and the phage combination were significantly more efficient than the positive control on all test plants except 'Idared' and 'Berecki'. The phage combination was most effective on flowers of the apple variety 'Golden delicious Reinders', while regarding its effectiveness displayed on other varieties it has been able to confine the number of bacteria significantly on 'Pinova' flowers compared to those assayed on the variety 'Idared'. It seems from our results that in both years the combination of phages implied one of the most effective treatments; it was significantly more efficient on the moderately resistant variety 'Pinova' than on the susceptible 'Idared'. Results gained from colony 
number assessment of reisolated bacteria (from samples of 'Idared', 2012) were confirmed by quantitative PCR as well.

Studying the antibacterial effects of phage isolates and their triple combination tested in the blossom assay on green pear fruit slices of three pear varieties we have found that the phages decreased fire blight symptoms compared to the positive control. During the first experiment application of the $\mathrm{H} 5 \mathrm{~K}$ isolate and the phage combination were significantly more efficient than the E. amylovora control in cases in all varieties. Assessing the correlation between the treatments and the plant varieties it was revealed that symptoms developed due to E. amylovora infection appeared less radically on fruit slices of 'Dr. Guyot Gyula' and 'Erdei vajkörte' than on 'Conference' in case of all phage treatments. In the repetion of the experiment all phage treatments applied on the variety 'Dr. Guyot Gyula' decreased fire blight symptoms significantly compared to the positive control. This effect could be verified only for $\mathrm{H} 2 \mathrm{~A}$ application in case of 'Erdei vajkörte' and for treatments of $\mathrm{H} 5 \mathrm{~K}$ and the phage combination in case of the variety 'Conference'. Comparing the effect of phage treatments between the varieties it was found that, as an effect of application of $\mathrm{H} 2 \mathrm{~A}$ and $\mathrm{H} 5 \mathrm{~K}$ phage isolates, fire blight symptoms got significantly reduced on the varieties of 'Dr. Guyot Gyula' and 'Erdei vajkörte' as compared to 'Conference'. No significant differences have been found among the effectiveness of each phage treatment except the distinction of phage $\mathrm{H} 2 \mathrm{~A}$ from H7B. However, the bacteria-eliminating effect of phages lagged behind from that of streptomycin-sulfate in all experiments. Based on the results the given phage treatments have proved to be more efficient on the pear variety 'Erdei vajkörte' and 'Dr. Guyot Gyula' as compared to 'Conference'.

Studying the effect of phage isolates H2A, H4A and H5A on blossoms of four ornamental plants succeptible to fire blight, their triple combination has proved to be the most successful. The treatment most effective in reducing symptoms developed due to E. amylovora inoculation was the application of the phage cocktail to the flowers of firethorn, while on sorb-apple and hawthorn the phage combination did not reduce-the extent of flower necrosis appreciably.

In order to improve the potential efficacy of phage-based biological control against fire blight we have investigated the uptake and in planta delivery of phages under steril circumstances. For these studies an American phage strain (ФEa104) and one of our own Hungarian isolates (H5K) were used. We found that (1) H5K phages were capable to translocate through the roots to the upper plant parts of apple seedlings and they could maintain their viability even for six days without the presence of the host bacterium. At the same time, their titer considerably decreased. (2) Both phages were detectable in plant parts above ground level following their application to the roots as well as in roots after spraying them onto the stem and leaves. Phages were detected in distal plant parts on the first sampling day in most of the 
samples, but we could not demonstrate the in planta presence of phages on the seventh day following phage applications in any of the samples. The difference between the two phages was manifested in the observation that the American phage strain was detectable in a higher number of samples, but for a shorter period of time as compared to the phage isolate H5K. Investigating the effectiveness of phages on symptoms developed due to an artificial inoculation with $E$. amylovora we have found that (3) applying phages either to the roots or to the aerial plant parts of apple seedlings the degree of symptoms caused by E. amylovora infection was significantly attenuated as compared to the untreated control. (4) After injecting their suspensions into one of the cotyledons of apple seedlings followed by immediate bacterial inoculation the degree of fire blight symptoms significantly decreased compared to the untreated control. However there were no significant differences between the effectiveness of the two phages in any of these experiments. Thus, we have shown that our tested bacteriophages specific to E. amylovora can penetrate test plants through their roots and aerial plant parts under certain conditions then translocate in plants to exhibit a decrease in severity of symptoms caused by this phytopathogenic bacterium.

Our phage isolates and their combinations as well as the new information on the in planta translocation ability of these phages could serve as a basis for further research promoting a more efficient application of bacteriophages for the control of fire blight. 


\section{IRODALOMJEGYZÉK}

Abedon, S.T. (2014): Phage therapy: Eco-physiological pharmacology. Scientifica Article ID 581639, 29 pages.

Abedon, S.T., Kuhl, S.J., Blasdel, B.G., Kutter, E.M. (2011): Phage treatment of human infections. Bacteriophage 1: 66-85.

Ackermann, H.W., DuBow, M.S. (1987): Viruses of Prokaryotes (vol. I): General properties of bacteriophages. CRC Press, Boca Raton, FL, USA.

Ackermann, H.W. (1998): Tailed bacteriophages: the Caudiovirales. Adv Virus Res 51: 135201.

Ackermann, H.W. (2007): 5500 Phages examined in the electron microscope. Arch Virol 152: 227-243.

Adams, M.H. (1959): Bacteriophages. Interscience Publishers, New York, USA.

Al-Arabi, F.K. (2002): Novel antagonistic bacteria as prospective agents for the biocontrol of some plant bacterial diseases. Doktori $(\mathrm{PhD})$ értekezés. Szent István Egyetem, Budapest, Magyarország.

Aldwinckle, H.S., Borejsza-Wysocka, E.E., Malnoy, M., Brown, S.K., Norelli, J.L., Beer, S.V., Meng, X., He, S.Y., Jin, Q.-L. (2003): Development of fire blight resistant apple cultivars by genetic engineering. Acta Hortic 622: 105-111.

Aldwinckle, H., Malnoy, M. (2009): Plant regeneration and transformation in the Rosaceae. Transgenic Plant Journal 3: 1-39.

Alexandrova, M., Bazzi, C., Lameri, P. (2002): Bacillus subtilis strain BS-F3: colonization of pear organs and its action as a biocontrol agent. Acta Hortic 590: 291-297.

Assadian, N.W., Di Giovanni, G.D., Enciso, J., Iglesias, J., Lindemann, W. (2005): The transport of waterborne solutes and bacteriophage in soil subirrigated with wastewater blend. Agr Ecosyst Environ111: 279-291.

Astier, S., Albouy, J., Maury, Y, Robaglia, C., Lecoq, H. (2007): Principles of Plant Virology: Genome, Pathogenicity, Virus Ecology. Science Publishers, Enfield, NH, USA.

Baker, K.F. (1971): Fire blight of pome fruits: the genesis of the concept that bacteria can be pathogenic to plants. Hilgardia 40: 603-633. 
Balogh, B., Canteros, B.I., Stall, R.E., Jones, J.B. (2008): Control of citrus canker and citrus bacterial spot with bacteriophages. Plant Dis 92: 1048-1052.

Balogh, B., Iriarte, F.B., Obradovic, A., Momol, T.M., Jones, J.B. (2007): Phages don't have it easy. Phytopathology 97: S141.

Balogh, B., Jones, J.B., Iriarte, F.B., Momol, T.M. (2010): Phage therapy for plant disease control. Curr Pharm Biotechnol 11: 48-57.

Balogh, B., Jones, J.B., Momol, T.M., Olson, S.M., Obradovic, A., Jackson, L.E. (2003): Improved efficacy of newly formulated bacteriophages for management of bacterial spot on tomato. Plant Dis 87: 949-954.

Barry, M.A., Dower, W.J., Johnston, S.A. (1996): Toward cell-targeting gene therapy vectors: selection of cell-binding peptides from random peptide-presenting phage libraries. Nat Med 2(3): 299-305.

Basim, H., Yeğen, O., Zeller, W. (2000): Antibacterial effect of essential oil of Thymbra spicata L. var. spicata on some plant pathogenic bacteria. Z Pflanzenk Pflanzen 279: 279-284.

Baysal, Ö., Laux, P., Zeller, W. (2002): Further studies on the induced resistance (IR) effect of plant extract from Hedera helix against fire blight (Erwinia amylovora). Acta Hortic 590: 273277.

Bellemann, P., Bereswill, S., Berger, S., Geider, K. (1994): Visualization of capsule formation by Erwinia amylovora and assays to determine amylovoran synthesis. Int J Biol Macromol 16: 290-296.

Bellemann, P., Geider, K. (1992): Localization of transposon insertions in pathogenicity mutants of Erwinia amylovora and their biochemical characterization. J Gen Microbiol 138: 931-940.

Bennett, R.A., Billing, E. (1978): Capsulation and virulence in Erwinia amylovora. Ann Appl Biol 89: 41-45.

Bereswill, S., Pahl, A., Bellemann, P., Zeller, W., Geider, K. (1992): Sensitive and speciesspecific detection of Erwinia amylovora by PCR-analysis. Appl Environ Microbiol 58: 35223526.

Bernhard, F., Coplin, D.L., Geider, K. (1993): A gene cluster for amylovoran synthesis in Erwinia amylovora: characterization and relationship to cps genes in Erwinia stewartii. Mol Gen Gen 239: 158-168. 
Billing, E. (1960): An association between capsulation and phage sensitivity in Erwinia amylovora. Nature 186: 819-820.

Billing, E (1980a): Fireblight in Kent, England in relation to weather (1955-1976). Ann Appl Biol 95: 341-364.

Billing, E. (1980b): Fireblight (Erwinia amylovora) and weather: a comparison of warning systems. Ann Appl Biol 95: 365-377.

Billing, E. (1984): Principles and applications of fire blight risk assessment systems. Acta Hortic 151: $15-22$.

Billing, E. (1996): BIS 95, An improved approach to fire blight risk assessment. Acta Hortic 411: 121-126.

Billing, E. (2000): Fire blight risk assessment system and models. In: Vanneste, J.L. (ed.) Fire blight: the disease and its causative agent, Erwinia amylovora. CABI Publishing, Wallingford, UK, 293-318.

Billing, E., Baker, L.A.E., Crosse, J.E., Garrett, C.M.E. (1961): Characteristics of English isolates of Erwinia amylovora (Burrill) Winslow et al. J Appl Bacteriol 24: 195-211.

Black, L.W. (1995): DNA packaging and cutting by phage terminases: control in phage T4 by a synaptic mechanism. Bioessays 17: 1025-30.

Bläsi, U., Young, R. (1996): Two beginnings for a single purpose: the dual-start holins in the regulation of phage lysis. Mol Microbiol 21: 675-682.

Bonn, W.G. (1999): Opening address. Acta Hotric 489: 27-28.

Bonn, W.G., van der Zwet, T. (2000): Distribution and economic importance of fire blight. In: Vanneste, J.L. (ed.) Fire blight. The disease and its causative agent, Erwinia amylovora. CABI Publishing, Wallingford, UK, 37-53.

Borejsza-Wysocka, E.E., Malnoy, M., Aldwinckle, H.S., Meng, X., Bonasera, J.M., Nissinen, R.M., Kim, J.F., Beer, S.V. (2006): The fire blight resistance of apple clones in which DspE-interacting proteins are silenced. Acta Hortic 704: 509-514.

Born, Y., Fieseler, L., Marazzi, J., Lurz, R., Duffy, B., Loessner, M.J. (2011): Novel virulent and broad-host-range Erwinia amylovora bacteriophages reveal a high degree of mosaicism and a relationship to enterobacteriaceae phages. Appl Environ Microbiol 77 (17): 5945-5954. 
Boulé, J., Sholberg, P.L., Lehman, S.M., O’Gorman, D.T., Svircev, A.M. (2011): Isolation and characterization of eight bacteriophages infecting Erwinia amylovora and their potential as biological control agents in British Columbia, Canada. Can J Plant Pathol 33: 308-317.

Boyd, R.J., Hildebrandt, A.C., Allen, O.N. (1971): Retardation of crown gall enlargement after bacteriophage treatment. Plant Dis Rep 55: 145-148.

Böszörményi, E., Érsek, T., Fodor, A., Fodor, A.M., Földes, L.Sz., Hevesi, M., Hogan, J.S., Katona, Z., Klein, M.G., Kormány, A., Pekár, S., Szentirmai, A., Sztaricskai, F., Taylor, R.A.J. (2009): Isolation and activity of Xenorhabdus antimicrobial compounds against the plant pathogens Erwinia amylovora and Phytophthora nicotianae. J Appl Microbiol 107: 746-759.

Brenner, D.J. (1984): Family I. Enterobacteriaceae. In: Krieg, N.R.A., Holt, J.G. (eds.) Bergey's Manual of Systemic Bacteriology 1. Williams and Wilkins, Baltimore, Maryland, USA, 408-420.

Broggini, G.A.L., Wöhner,T., Fahrentrapp, J., Kost, T.D., Flachowsky, H., Peil, A., Hanke, M.-V., Richter, K., Patocchi, A., Gessler, C. (2014): Engineering fire blight resistance into the apple cultivar 'Gala' using the FB_MR5 CC-NBS-LRR resistance gene of Malus x robusta 5. Plant Biotechnol J 12: 728-733.

Brusina, E.B., Drozdova, O.M., Kutikhin, A.G. (2013): A new method of bacteriophage-based disinfection in healthcare settings. Antimicrobial Resistance and Infection Control 2 (Suppl 1): $\mathrm{O} 20$.

Bubán, T, Dorgai, L (2003): Az Erwinia amylovora fertőzési veszélyt előrejelző egyszerü módszerek összehasonlítása. Fruitinfo-Alma 12: 4-5.

Bubán, T, Lakatos, T., Tóth, T., Dorgai, L., Hudák, I., Hevesi, M., Stockwell, V.O. (2007): Különböző antagonista baktériumok hatékonysága az Erwinia amylovorával szemben. Növényvédelem 43: 531-538.

Bubán, T., Orosz-Kovács, Zs., Farkas, Á. (2003a): The nectary as the primary site of infection by Erwinia amylovora (Burr.) Winslow et al.: a mini review. Plant Syst Evol 238: 183-194.

Bubán T., Orosz-Kovács, Zs., Farkas, Á. (2003b): Az Erwinia amylovora fertőzés elsődleges helye a virágok nektáriuma. Kertgazdaság 1: 10-16.

Bugert, P., Geider, K. (1995): Molecular analysis of the ams operon required for exopolysaccharide synthesis of Erwinia amylovora. Mol Microbiol 15: 917-933.

Burrill, A.C. (1882): The bacteria: an account of their nature and effects, together with a systematic description of the species. III. Indus Univ Ann Rpt 11: 93-157. 
Bustin, S.A., Benes, V., Garson, J.A., Hellemans, J., Huggett, J., Kubista, M., Mueller, R., Nolan, T., Pfaffl, M.W., Shipley, G.L., Vandesompele, J., Wittwer, C.T. (2009): The MIQE Guidelines: Minimum information for publication of quantitative Real-Time PCR experiments. Clin Chem 55: 611-622.

Campbell, J.A. (1920): The orchard: the outbreak of fire blight. New Zeal J Agr 20: 181-182.

Carlsson, A., Nyström, T., de Cock, H., Bennich, H. (1998): Attacin - an insect immune protein - binds LPS and triggers the specific inhibition of bacterial outer-membrane protein synthesis. Microbiology 144: 2179-2189.

Cheng, H., Shen, N., Pei, J., Grishin, N.V. (2004): Double-stranded DNA bacteriophage prohead protease is homologous to herpesvirus protease. Protein Sci 13: 2260-2269.

Chester, F.D. (1897): A preliminary arrangement of the species of the genus bacterium; bacteria associated with diseases of plants; notes on pear blight; pear canker treatment. Del Agr Expt Sta Ann Rpt 9: 127 p.

Chiou, C.-S., Jones, A.L. (1991): The analysis of plasmid-mediated streptomycin resistance in Erwinia amylovora. Phytopathology 81: 710-714.

Christensen, B., Fink, J., Merrifield, R., Mauzerall, D. (1988): Channel-forming properties of cecropins and related model compounds incorporated into planar lipid membranes. P Natl Acad Sci USA 85: 5072-76.

Civerolo, E.L. (1972): Interaction between bacteria and bacteriophage on plant surfaces and in plant tissues. In: Maas Geesteranus, H.P. (ed.) Proc Centre Agric Publ Doc. Wageningen, Netherlands, 25-37.

Civerolo, E.L., Kiel, H.L. (1969): Inhibition of bacterial spot of peach foliage by Xanthomonas pruni bacteriophage. Phytopathology 59: 1966-1967.

Clark, J.R., March, J.B (2004): Bacterial viruses as human vaccines? Expert Rev Vaccines 3(4): 463-476.

Coplin, D.L., Majerczak, D.R., Zhang, Y., Kim, W.-S., Jock, S., Geider, K. (2002): Identification of Pantoea stewartii subsp. stewartii by PCR and strain differentiation by PFGE. Plant Dis 86: 304-311.

Coplin, D.L., Rowan, R.G., Chisholm, D.A., Whitmoyer, R.E. (1981): Characterization of plasmids in Erwinia stewartii. Appl Environ Microbiol 42: 599-604.

Coxe, W (1817): Pears. In: Coxe, W (ed.) Cultivation of fruit trees. Philadelphia, 175-176. 
Coyier, D.L., Covey, R.P. (1975): Tolerance of Erwinia amylovora to streptomycin sulfate in Oregon and Washington. Plant Dis Rep 59: 849-852.

Crosse, J.E., Hingorani, M.K. (1958): A method for isolating Pseudomonas mors-prunorum phages from the soil. Nature 181: 60-61.

Csete, S., Garai, A., Zsolnai, G. (2004): Helyzetkép a tüzelhalásról 2004 tavaszán BorsodAbaúj-Zemplén megyében. Gyakorlati Agrofórum 15: 68-69.

de León-Door, A.P, Romo Chacón, A., Acosta Muñiz, C. (2013): Detection of streptomycin resistance in Erwinia amylovora strains isolated from apple orchards in Chihuahua, Mexico. Eur J Plant Pathol 137: 223-229.

Denning, W. (1794): On the decay of apple trees. New York society for the promotion of agricultural arts and manufacturers transaction 2: 219-222.

d'Herelle, F. (1917): Sur un microbe invisible antagoniste des bacilles dysentériques. $C R$ Acad Sci 165: 373-375.

Dömötör, D., Becságh, P., Rákhely, G., Schneider, Gy., Kovács, T. (2012): Complete genomic sequence of Erwinia amylovora Phage PhiEaH2. J Virol 86: 10899.

Dreo, T., Zupancic, M., Demsar, T., Ravnikar, M. (2006): First outbreak of fire blight in Slovenia. Acta Hortic 704: 37-41.

Duffy, B., Walsh, F., Pelludat, C., Holliger, E., Oulevet, C., Widmer, F. (2011): Environmental monitoring of antibiotic resistance and impact of streptomycin use on orchard bacterial communities. Acta Hortic 896: 483-488.

El-Goorani, M.A., El-Kasheir, H.M., Shoeib, A.A., Hassanein, F.M. (1989): Distribution of streptomycin resistant strains of Erwinia amylovora in Egypt during 1988. J Phytopathol 127: 69-74.

El-Helaly, A.F., Abo-El-Dahab, M.K., El-Goorani, M.A. (1964): The occurrence of fire blight disease of pear in Egypt. Phytopathol Mediterr 3: 156-163.

Erskine, J.M. (1973): Characteristics of Erwinia amylovora bacteriophage and its possible role in the epidemiology of fire blight. Can J Microbiol 19: 837-845.

Ertl, C., Mögel, G., Kunz, S., Donat, C., Danner, H. (2007): From the laboratory to the market - The success story of Blossom Protect. Abstracts of $11^{\text {th }}$ International workshop on Fire Blight, 12-17 August, Portland, Oregon, 2007. Abstracts: 79.

Evans, I.R. (1996): Fire blight of raspberries in Alberta. Acta Hortic 411: 69-72. 
Falkenstein, H., Bellemann, P., Walter, S., Zeller, W., Geider, K. (1988): Identification of Erwinia amylovora, the fireblight pathogen, by colony hybridization with DNA from plasmid pEa29. Appl Environ Microbiol 54: 2798-2802.

Flaherty, J.E., Harbaugh, B.K., Jones, J.B., Somodi, G.C., Jackson, L.E. (2001): H-mutant bacteriophages as a potential biocontrol of bacterial blight of geranium. Hortic Sci 98-100.

Flaherty, J.E., Jones, J.B., Harbaugh, B.K., Somodi, G.C., Jackson, L.E. (2000): Control of bacterial spot on tomato in the greenhouse and field with H-mutant bacteriophages. Hortic Sci 35: $882-884$.

Frampton, R.A., Pitman, A.R., Fineran, P.C. (2012): Advances in bacteriophage-mediated control of plant pathogens. Int J Microbiol Article ID 326452, 11.

Fujiwara, A., Hamasaki, R., Kawasaki, T., Makoto Fujie, M., Yamada, T. (2011): Biocontrol of Ralstonia solanacearum by treatment with lytic bacteriophages. Appl Environ Microbiol 77: 4155-4162.

Fülep, I. (2014): A tüzelhalásról az elmúlt évek tapasztalatainak a tükrében. Agrofórum extra 53: 54-56.

Gavini, F., Mergaert, J., Beji, A., Mielcarek, Ch., Izard, D., Kersters, K., De ley, J. (1989): Transfer of Enterobacter agglomerans (Beijerinck 1888) Ewing and Fife 1972 to Pantoea gen. nov. as Pantoea agglomerans comb. nov. and description of Pantoea dispersa sp. Nov. Int J Syst Bacteriol 39: 337-345.

Geider, K. (2000): Exopolysaccharides of Erwinia amylovora: structure, biosynthesis, regulation, role in pathogenicity of amylovoran and levan. In: Vanneste, J.L. (ed.) Fire blight: the disease and its causative agent, Erwinia amylovora. CABI Publishing, Wallingford, UK, 117-140.

Geier, G., Geider, K. (1993): Characterization and influence on virulence of the levansucrase gene from the fire blight pathogen Erwinia amylovora. Physiol Mol Plant Pathol 42: 387-404.

Gill, J., Abedon, S.T. (2003): Bacteriophage Ecology and Plants. APSnet Features, Online. https://www.apsnet.org/publications/apsnetfeatures/Pages/BacteriophageEcology.aspx, 17.

Gill, J.J., Svircev, A.M., Smith, R., Castle, A.J. (2003): Bacteriophages of Erwinia amylovora. Appl Environ Microbiol 69: 2133-2138.

Glits, M. (1993): Almatermésűek betegségei. In: Glits, M., Folk, Gy. (eds.) Kertészeti növénykórtan. Mezőgazda Kiadó, Budapest, Magyarország, 157-188. 
Goodridge, L.D., Bisha, B. (2011): Phage-based biocontrol strategies to reduce foodborne pathogens in foods. Bacteriophage 1: 130-137.

G. Tóth, M. (1997): Almagyümölcsủek. In: G. Tóth, M. (ed.) Gyümölcsészet. Primom, Debrecen, Magyarország, 29-110.

Guttman, B., Raya, R., Kutter, E. (2005): Basic phage biology. In: Kutter, E., Sulakvelidze, A. (eds.) Bacteriophages: Biology and Applications. CRC Press, Boca Raton, FL, USA, 29-66.

Hamilton, R.H., Fall, M.Z. (1971): The loss of tumor initiating ability in Agrobacterium tumefaciens by incubation at high temperature. Experientia 27: 229-230.

Hanahan, D. (1985) Techniques for transformation of E. coli. In: Glover, D.M. (ed.) DNA Cloning: A Practical Approach. Vol. 1. IRL Press, McLean, Virginia, 109.

Hanke, V., Geider, K., Richter, K. (2003): Transgenic apple plants expressing viral EPS depolimerase: Evaluation of resistance to the phytopathogenic bacterium Erwinia amylovora. In: Kluwer, V.I.K. (ed.) Plant Biotechnology 2002 and Beyond. Academic Publishers, Dordrecht, Netherlands, 153-157.

Hao, M.V., Brenner, D.J., Steigerwalt, A.G., Kosako, Y., Komagata, K. (1990). Erwinia persicinus, a new species isolated from plants. Int J Syst Bacteriol 40: 379-383.

Haq, I.U., Chaudhry, W.N., Akhtar, M.N., Andleeb, S., Qadri, I. (2012): Bacteriophages and their implications on future biotechnology: a review. Virol. J 9: 9.

Hartung, J.S., Fulbright, D.W., Klos, E.J. (1988): Cloning of a bacteriophage polysaccharide depolymerase gene and its expression in Erwinia amylovora. Mol Plant Microbe Interact 1: 8793.

Hauben, L., Moore, E.R.B., Vauterin, L., Steenackers, M., Mergaert, J., Verdonck, L., Swings, J. (1998): Phylogenetic position of phytopathogens within Enterobacteriaceae. Syst Appl Microbiol 21: 384-397.

Heimann, M.F., Worf, G.L. (1985). Fire blight of raspberry caused by Erwinia amylovora in Wisconsin. Plant Dis 69: 360.

Helms, K., Wardlaw, I.F. (1976): Movement of viruses in plants: long distance movement of tobacco mosaic virus in Nicotiana glutinosa. In: Wardlaw, I.F., Passioura, J.B. (eds.) Transport and transfer processes in plants. New York Academic Press, USA, 283-293.

Hevesi, M. (1996): Az Erwinia amylovora (Burrill) Winslow et al. hazai megjelenése almán. Növényvédelem 32 (5): 225-228. 
Hevesi, M., Al-Arabi, K.F. (1999): Isolation of epiphytic bacterium antagonistic to Erwinia amylovora. Acta Hortic 489: 619-622.

Hevesi, M., Bója, N., Bánátfy, R., Babulka, P., Tóth, M. (2006a): In vitro inhibition of growth of Erwinia amylovora by plant oils. Mitt Biol Bundesanst Land - Forstwirscht 408: 262-264.

Hevesi, M., Hudák, I., Dorgai, L., Szentkirályi, A., Bubán, T. (2006b): Pantoea agglomerans HIP32: a new bacterial antagonist to Erwinia amylovora. Phytopathol Pol 39: 79-85.

Hevesi, M., Tornai-Lehoczki, J., Tóth, M., Végh, A., Petróczy, M., Palkovics, L. (2008): Characterization of HIP 32 bacterium antagonistic to Erwinia amylovora. Host Pathogen Interactions In Pome Fruits. Abstracts of the Working Groups 1-3 and Management Commitee Meeting and Joint Meeting of Cost Action 864: 52-53.

Hildebrand, E.M. (1937): The blossom-blight phase of fire blight and methods of control. Cornell University Agriculture Experiment Station Memoires 207. Ithaka, NewYork, USA, 40.

Holt, J.G., Krieg, N.R., Sneath, P.H.A., Staley, J.T., Williams, S.T. (1994): Bergey's Manual of Determinative Bacteriology. The Williams and Wilkins Co., Baltimore, Maryland, USA.

Honty, K. (2011): Körtefajták tüzelhalással szembeni ellenállósága és a betegség folyamatának jellemzése néhány biokémiai paraméter vizsgálatával. Doktori $(\mathrm{PhD})$ értekezés. Budapesti Corvinus Egyetem, Budapest, Magyarország.

Honty, K., Hevesi, M., Göndör, M., Tóth, M., Bács-Várkuti, V., Ferenczy, A. (2004): Susceptibility of soma traditional pear cultivars of Hungarian and foreign origin to the pathogenic bacterium Erwinia amylovora. Int J Hortic Science 10: 41-45.

Hultmark, D., Engström, Å., Andersson, K., Steiner, H., Bennich, H., Boman, H.G. (1983): Insect immunity. Attacins, a family of antibacterial proteins from Hyalophora cecropia. EMBO J. 2: 571-576.

Hultmark, D., Steiner, H., Rasmuson, T., Boman, H.G. (1980): Insect immunity. Purification and properties of three inducible bactericidal proteins from hemolymph of immunized pupae of Hyalophora cecropia. Eur J Biochem 106: 7-16.

Hyman, P., Abedon, S.T. (2010): Bacteriophage host range and bacterial resistance. Adv Appl Microbiol 70: 217-248.

Iriarte, F.B., Balogh, B., Momol, T.M., Smith, L.M., Wilson, M., Jones, J.B. (2007): Factors affecting survival of bacteriophage on tomato leaf surfaces. Appl Environ Microb 73: 1704-1711.

Iriarte, F.B., Obradovic, A., Wernsing, M.H., Jackson, L.E., Balogh, B., Hong, J.A., Momol, T.M., Jones, J.B., Vallad, G.E. (2012): Soil-based systemic delivery and phyllosphere 
in vivo propagation of bacteriophages: Two possible strategies for improving bacteriophage persistence for plant disease control. Bacteriophage 2: 215-224.

Jackson, L.E. (1989): Bacteriophage prevention and control of harmful plant bacteria. US 4828999.

Jackson, L.E., Spendlove, R.S. (2007): Method of treating food products. EP 1845784 A2.

Jelkmann, W., Lindner, A. (2008): Studies on antagonistic yeast species against Erwinia amylovora in co-culture and on apple blossoms. Acta Hortic 793: 403-408.

Johnson, K.B., Stockwell, V.O. (2000): Biological control of fire blight. In: Vanneste, J.L. (ed.) Fire blight: the disease and its causative agent, Erwinia amylovora. CABI Publishing, Wallingford, UK, 319-337.

Johnson, K.B., Stockwell, V.O., McLaughlin, M.J., Sugar, D., Loper, J.E., Roberts, R.G. (1993): Effect of bacterial antagonists on establishment of honey bee-dispersed Erwinia amylovora in pear blossoms and on fire blight control. Phytopathology 83: 995-1002.

Johnson, R.P., Gyles, C.L., Huff, W.E., Ojha, S., Huff, G.R., Rath, N.C., Donoghue, A.M. (2008): Bacteriophages for prophylaxis and therapy in cattle, poultry and pigs. Animal Health Research Reviews 9: 201-215.

Jones, A.L., Schnabel, E.L. (2000): The development of streptomicin-resistant strains of Erwinia amylovora. In: Vanneste, J.L. (ed.) Fire blight: the disease and its causative agent, Erwinia amylovora. CABI Publishing, Wallingford, UK, 235-251.

Jones, J.B., Jackson, L.E., Balogh, B., Obradovic, A., Iriarte, F.B., Momol, T.M. (2007): Bacteriophages for plant disease control. Annu Rev Phytopathol 45: 245-262.

Kageyama, B., Nakae, M., Yagi, S., Sonoyama, T. (1992): Pantoea punctata sp. nov., Pantoea citrea sp. nov., and Pantoea terrea sp. nov. isolated from fruit and soil samples. Int J Syst Bacteriol 42: 203-210.

Keck, M., Chartier, R., Zislavsky, W., Paulin, J. P. (1990): Sensitivity of Erwinia amylovora to high temperatures- possible use of heat treatment for plant propagation material. Acta Hortic 338: $311-316$.

Keck, M., Hevesi, M., Ruppitsch, W., Ströger, A., Richter, S. (2002): Spread of fire blight in Austria and Hungary-variability of Erwinia amylovora strains. Plant Prot Sci 38: 49-55.

Kersters, K., Ludwig, W., Vancanneyt, M., De Vos, P., Gillis, M., Schleifer, K.-H. (1996): Recent change in the classification of the pseudomonads: an overveiw. Syst Appl Microbiol 19: 465-477. 
Kim, W.S., Geider, K. (2000): Characterization of a viral EPS-depolymerase, a potential tool for control of fire blight. Phytopathology 90: 1263-1268.

Kim, W.S., Salm, H., Geider, K. (2004): Expression of bacteriophage $\Phi$ Ea1h lysozyme in Escherichia coli and its activity in growth inhibition of Erwinia amylovora. Microbiol 150: 2707-2714.

Király, I., Tóth, M. (2009): Újra termesztésbe vonható régi magyar almafajták. Agrofórum extra 28: 28-29.

Kleitman, F., Shtienberg, D., Blachinsky, D., Oppenheim, D., Zilberstaine, M., Dror, O., Manulis, S. (2005): Erwinia amylovora populations resistant to oxolinic acid in Israel: prevalence, persistence and fitness. Plant Pathol 54: 108-115.

Klement, Z. (1959): Some new specific bacteriophages for plant pathogenic Xanthomonas spp. Nature 184: 1248-1249.

Klement, Z. (1963): Method for the rapid detection of the pathogenicity of phytopathogenic Pseudomonas. Nature 199: 299-300.

Klement, Z. (1965): Baktériumos növénybetegségek. Erwinia amylovora. In: Ubrizsy, G. (ed.) Növénykórtan I. Akadémiai Kiadó, Budapest, Magyarország, 481-482.

Klement, Z., Király, Z. (1957): Hyperparasitic chain of a fungus, a bacterium and its phage on wheat. Nature 179: 157-158.

Klement, Z., Lovas, B. (1957): The new bacteriophages for Corynebacterium flaccumfaciens and Xanthomonas phaseoli var. fuscans pathogens of bean. Nature 180: 41-42.

Klement, Z., Lovas, B. (1959): Isolation and characterization of a bacteriophage for Corynebacterium flaccumfaciens. Phytopathology 49: 107-112.

Klement, Z., Lovas, B. (1960): Biological and morphological characterization of the phage for Xanthomonas phaseoli var. fuscans. Phytopath Z 37: 321-329.

Ko, K., Norelli, J.L., Reynoird, J., Aldwinckle, H.S., Brown, S. (2002): T4 lysozyme and attacin genes enhance resistance of transgenic 'Galaxy' apple against Erwinia amylovora (Burr.). J Am Soc Hortic Sci 127: 515-519.

Ko, K., Norelli, J.L., Reynoird, J.-P., Borejsza-Wysocka, E., Brown, S.K., Aldwinckle, H.S. (2000): Effect of untranslated leader sequence of AMV RNA 4 and signal peptide of pathogenesis-related protein $1 \mathrm{~b}$ on attacin gene expression, and resistance to fire blight in transgenic apple. Biotechnol Lett 22: 373-381. 
Koch, G., Dreyer, W.J. (1958): Characterization of an enzyme of phage T2 as a lysozyme. Virology 6: 291-293.

Koch, A., Kogel, K.H. (2014): New wind in the sails: improving the agronomic value of crop plants through RNAi-mediated gene silencing. Plant Biotechnol J 1-11.

Kokoskova, B., Pouvova, D., Pavela, R. (2011): Effectiveness of plant essential oils against Erwinia amylovora, Pseudomonas syringae pv. syringae and associated saprophytic bacteria on/in host plants. J Plant Pathol 93: 133-139.

Korba, J., Sillerova, S. (2010): First occurence of fire blight infection on apricot (Prunus armeniaca) in Chech Republic. Abstracts of $12^{\text {th }}$ International Workshop on Fire Blight. 16-20 August 2010, Warsaw, Poland. Abstracts: 107.

Kovács, T., Gáll, J., Kovács, Á.L., Schneider, Gy., Rákhely, G. (2012): Development and application of phage therapy based pesticides: practical experiences. The Hungarian Society for Microbiology's Congress of the year 2012. 24-26 October 2012, Keszthely, Hungary.

Kovács, T., Várnai, N.Á., Dömötör, D., Rákhely, G., Schneider, Gy. (2013): Phage therapy base pesticides: practical experiences. $2^{\text {nd }}$ Biotechnology World Congress. 18-21 February 2013, Dubai, UAE.

Kozloff, L.M., Schnell, R.C. (1983): Protection of plants against frost injury using ice nucleation-inhibiting species-specific bacteriophages. US 4375734 A.

Kube, M., Migdoll, A.M, Gehring, I., Heitmann, K., Mayer, Y., Kuhl, H., Knaust, F., Geider, K., Reinhardt, R. (2010): Genome comparison of the epiphytic bacteria Erwinia billingiae and E. tasmaniensis with the pear pathogen E. pyrifoliae. BMC Genomics 11: 393.

Kunz, S., Eitzen-Ritter von, M., Schmitt, A., Haug, P. (2004): Feuerbrandbekämpfung im ökologischen Obstbau. Ökoobstbau 4: 2-7.

Kunz, S., Schmitt, A., Haug, P. (2011): Development of strategies for fire blight control in organic fruit growing. Acta Hortic 896: 431-436.

Kutateladze, M., Revaz, A. (2010): Bacteriophages as potential new therapeutics to replace or supplement antibiotics. Trends Biotechnol 28: 591-595.

Kutter, E. (2009): Bacteriophage therapy: Past and present. In: Schaechter, M. (ed.) Encyclopedia of Microbiology. Elsevier, Oxford, UK, 258-266.

Kutter, E., Sulakvelidze, A. (2005): Bacteriophages: Biology and Applications. CRC Press, Boca Raton, FL, USA. 
Laux, P., Wesche. J., Zeller, W. (2003): Field experiments on biological control of fire blight by bacterial antagonists. J Plant Dis Plant Prot 110: 401-407.

Lang, J.M., Gent, D.H., Schwartz, H.F. (2007): Management of Xanthomonas leaf blight of onion with bacteriophages and a plant activator. Plant Dis 91: 871-878.

László, Gy. (2008): Az almatermésűek tűzelhalása (Erwinia amylovora) elleni új védekezési lehetőség Magyarországon. Növényvédelem 44: 147-149.

Lecomte, P., Cadic, A. (1993): Further results on shoot susceptibility of Cotoneaster to fire blight. Acta Hortic 338: 407-412.

Lederberg, J., Lederberg, E.M., Zinder, N.D., Lively, E.R. (1951): Recombination analysis of bacterial heredity. Cold Spring Harbor symposia on quantitative biology 16: 413-443.

Lehman, S.M. (2007): Development of a bacteriophage-based biopesticide for fire blight. Doktori (PhD) értekezés. Ontario, Brock University, USA.

Lehman, S.M., Kropinski, A.M., Castle, A.J., Svircev, A.M. (2009): Complete genome of the broad-host-range Erwinia amylovora phage Ea21-4 and its relationship to Salmonella phage Felix O1. Appl Environ Microb 75: 2139-2147.

Lelliott, R.A. (1959): Fire blight of pears in England. Agriculture (London) 65: 564-568.

Lespinasse, Y., Aldwinckle, H.S. (2000): Breeding for resistance to fire blight. In: Vanneste, J.L. (ed.) Fire blight: the disease and its causative agent, Erwinia amylovora. CABI Publishing, Wallingford, UK, 253-292.

Lindow, S.E., McGourty, G., Elkins, R. (1996): Interactions of antibiotics with Pseudomonas fluorescens strain A 506 in the control of fire blight and frost injury to pear. Phytopathology 86: 841-848.

Liu, Q., Ingersoll, J., Owens, L., Salih, S., Meng, R., Hammerschlag, F. (2001): Respons of transgenic Royal Gala apple (Malus x domestica Borkh.) shoots carrying a modified cecropin MB39 gene, to Erwinia amylovora. Plant Cell Rep 20: 306-312.

Llop, P., Cabrefiga, J., Smits, T.H.M., Dreo, T., Barbé, S., Pulawska, J., Bultreys, A., Blom, J., Duffy, B., Montesinos, E., López, M.M. (2011): Erwinia amylovora novel plasmid pEI70: complete sequence, biogeography, and role in aggressiveness in the fire blight phytopathogen. PLoS One 6: e28651.

Llop, P., Donat, V., Rodríguez, M., Cabrefiga, J., Ruz, L., Palomo, J.L., Montesinos, E., López, M.M. (2006): Anindigenous virulent strain of Erwinia amylovora lacking the ubiquitous plasmid pEA29. Phytopathology 96: 900-907. 
Loeb, T., Zinder, N.D. (1961): A bacteriophage containing RNA. Proc Natl Acad Sci USA 47: 282-289.

Mallmann, W.L., Hemstreet, C. (1924): Isolation of an inhibitory substance from plants. J Agr Res 28: 599-602.

Malnoy, M., Faize, M, Venisse, J.S., Geider, K., Chevreau, E. (2005): Expression of viral EPS-depolimerase reduces fire blight susceptibility in transgenic pear. Plant Cell Rep 23: 632638.

Malnoy, M., Jin, Q., Borejsza-Wysocka, E.E., He, S.Y., Aldwinckle, H.S. (2007): Overexpression of the apple MpNPR1 gene confers increased disease resistance in Malus $\mathrm{x}$ domestica. Mol Plant Microbe In 17: 1568-1580.

Maniloff, J., Ackermann, H-W. (1998): Taxonomy of bacterial viruses: establishment of tailed virus genera and the other Caudovirales. Arch Virol 143: 2051-2063.

Manulis, S., Zutra, D., Ga'ash, D., Kleitman, F., Dror, O., Elisha, S., David, I., Rav-David, D., Zilberstain, M., Herzog, Z., Shabi, E. (1996): Streptomycin resistance of Erwinia amylovora in Israel and occurrence of blossom blight in the autumn. Phytoparasitica 24: 161.

Marroni, I.V., Germani, J.C. (2014): New technique to create a suspension containing bacteriophages and how it can be used to control cabbage leaf spot caused by Xanthomonas campestris pv. campestris. Agricultural Sciences 5: 286-297.

Martin, C. (1988): The Application of bacteriophage tracer techniques in South West water. Water Environ J 2: 638-642.

Mazur, B., Paciorkiewicz, W. (1973): Dissemination of enteroviruses in the human environment I. Presence of poliovirus in various parts of vegetable plants grown on infected soil. Medycyna Doświadczalna i Mikrobiologia 25: 93-98.

Mc Grath, S., van Sinderen, D. (2007): Bacteriophage: genetics and molecular biology. Caister Academic Press, Norfolk, England.

McKenna, F., El-Tarabily, K.A., Hardy, G.E.S.T., Dell, B. (2001): Novel in vivo use of a polyvalent Streptomyces phage to disinfest Streptomyces scabies-infected seed potatoes. Plant Pathol 50: 666-675.

McNeil, D.L., Romero, S., Kandula, J., Stark, C., Stewart, A., Larsen, S. (2001): Bacteriphages: a potential biocontrol agent against walnut blight (Xanthomonas campestris pv. juglandis). N Z Plant Protect-Se 54: 220-224. 
Meczker, K., Domotor, D., Vass, J., Rakhely, G., Schneider, G., Kovacs, T. (2014): The genome of the Erwinia amylovora phage PhiEaH1 reveals greater diversity and broadens the applicability of phages for the treatment of fire blight. FEMS Microbiol Lett 350: 25-27.

Mergaert, J., Hauben, L., Cnockaert, M.C., Swings, J. (1999): Reclassification of nonpigmented Erwinia herbicola strains from trees as Erwinia billingiae sp. nov. Int J Syst Bacteriol 49: 377-383.

Mérő, F. (2004): Helyzetkép a tűzelhalásról 2004 tavaszán Szabolcs-Szatmár-Bereg megyében. Gyakorlati Agrofórum 15: 70-71.

Milch, H. (2000): Bakteriofágterápia és profilaxis - Régebbi remények újraéledése. Lege Artis Medicinae 10: 660-665.

Milch, H., Pászti, J. (2008): Fágtípusmeghatározástól a molekuláris epidemiológiáig: kutatási eredmények a gyakorlati tevékenységben. Egészségtudomány 52: 28-44.

Miller, T.D., Schroth, M.N. (1972): Monitoring the epiphytic population of Erwinia amylovora on pear with a selective medium. Phytopathology 62: 1175-1182.

Mohan, S.K. (2007): Natural infection of shoot blight in Pluot ${ }^{\circledR}$ caused by Erwinia amylovora. Abstracts of $11^{\text {th }}$ International Workshop on Fire Blight. 12-17 August 2007, Portland, Oregon, USA. Abstracts: 64.

Mohan, S.K., Thomson, S.V. (1996): An outbreak of fire blight in plums. Acta Hortic 411: 7376.

Molineux, I.J. (2006): Fifty-three years since Hershey and Chase; much ado about pressure but which pressure is it? Virology 344: 221-229.

Moller, W.J., Schroth, M.N., Thomson, S.V. (1981): The scenario of fire blight and streptomycin resistance. Plant Dis 65: 563-568.

Momol, T.M., Aldwinckle, H.S. (2000): Genetic diversity and host range of Erwinia amylovora. In: Vanneste, J.L. (ed.) Fire blight. The disease and its causative agent, Erwinia amylovora. CABI Publishing, Wallingford, UK, 55-72.

Mosch, J., Klingauf, F., Zeller, W. (1989): On the effect of plant extracts against fireblight (Erwinia amylovora). Acta Hortic 273: 355-361.

Mosch, J., Zeller, W., Prokop, A. (2000): Versuche zur Feuerbrandbekämpfung (Erwinia amylovora) durch induzierte Resistenz im Gewächshaus und Freiland. Mitt Biol Bundesanst Land Forstwirtsch Berl-Dahlem 376: 407. 
Munsch, P., Olivier, J.M. (1995): Biocontrol of bacterial blotch of the cultivated mushroom with lytic phages: some practical consideration. In: Elliott, T.J. (ed.) Science and cultivation of edible fungi. Balkema, Rotterdam, The Netherlands, 595-602.

Murphy, W.H., Syverton, J.T. (1958): Absorption and translocation of mammalian viruses by plants. II. Recovery and distribution of viruses in plants. Virology 6: 623.

Müller, I., Kube, M., Reinhardt, R., Jelkmann, W., Geider, K. (2011b): Complete genome sequences of three Erwinia amylovora phages isolated in North America and a bacteriophage induced from an Erwinia tasmaniensis strain. J Bacteriol 193: 795-796.

Müller, I., Lurz, R., Kube, M., Quedenau, C., Jelkmann, W., Geider, K. (2011a): Molecular and physiological properties of bacteriophages from North America and Germany affecting the fire blight pathogen Erwinia amylovora. Microb Biotechnol 4: 735-745.

Nagy, J.K., Király, L., Schwarczinger, I. (2012): Phage therapy for plant disease control with a focus on fire blight. Cent Eur J Biol 1: 1-12.

Németh, J. (1997): Az almatermésüek baktériumos hajtásszáradása és elhalása (tüzelhalás) kórokozó: Erwinia amylovora. Alapvetö ismeretek a betegségröl és az ellene való védekezés lehetöségéröl. Szakmai információs anyag. Agroinform Kiadó, Budapest, Magyarország, 1-32.

Norelli, J.L., Aldwinckle, H.S. (2000): Transgenic varieties and rootstocks resistant to fire blight. In: Vanneste, J.L. (ed.) Fire blight: the disease and its causative agent, Erwinia amylovora. CABI Publishing, Wallingford, UK, 275-292.

Norelli, J.L., Aldwinckle, H.S., Destéfano-Beltrán, L., Jaynes, J.M. (1994): Transgenic 'Malling 26' apple expressing the attacin E gene has increased resistance to Erwinia amylovora. Euphytica 77: 123-128.

Norelli, J.L., Mills, J.Z., Momol, M.T., Aldwinckle, H.S. (1999): Effect of cecropin-like transgenes on fire blight resistance of apple. Acta Hortic 489: 273-278.

Ocskó, Z., Erdős, Gy., Molnár, J. (2014): Növényvédő szerek, termelésnövelő anyagok I. Reálszisztéma Dabasi Nyomda, Dabas, Magyarország.

OEPP/EPPO (1983): Data sheets on quarantine organisms No. 52., Erwinia amylovora. OEPP/EPPO Bulletin 13: 1-6.

Ohnishi, Y., Ishikawa, J., Hara, H., Suzuki, H., Ikenoya, M., Ikeda, H., Yamashita, A., Hattori, M., Horinouchi, S. (2008): Genome sequence of the streptomycin-producing microorganism Streptomyces griseus IFO 13350. J Bacteriol 190: 4050-4060. 
Okabe, N., Goto, M. (1963): Bacteriophages of plant pathogens. Annu Rev Phytopathol 1: 397418.

Oron, G., Goemans, M., Manor, Y., Feyen, J. (1995): Poliovirus distribution in the soil-plant system under reuse of secondary wastewater. Water Res. 29: 1069-1078.

Paulin, J.P. (2000): Erwinia amylovora: general characteristics, biochemistry and serology. In: Vanneste, J.L. (ed.) Fire blight: the disease and its causative agent, Erwinia amylovora. CABI Publishing, Wallingford, UK, 87-115.

Paulin, J.P., Keck, M., Chartier, R., Zislavsky, W. (1990): Versuche zur Beurteilung der Feuerbrandanfälligkeit von Kernobstsorten nach Infektion unreifer Früchte. Pflanzenschutzberichte 51: 91-98.

Pálfi, K., Vendrei, Zs., Csete, S., Simon, Z., Sótonyi, J., Lőrinczné Izsáki, G. (2000): Az almatermésűek tűzelhalásos betegsége (Erwinia amylovora) Magyarországon, 2000-ben. Integrált termesztés a kertészeti és szántóföldi kultúrában 21: 12-17.

Psallidas, P.G., Tsiantos, J. (2000): Chemical control of fire blight. In: Vanneste, J.L. (ed.) Fire blight: the disease and its causative agent, Erwinia amylovora. CABI Publishing, Wallingford, UK, 199-234.

Pusey, P.L., Stockwell, V.O., Mazzola, M. (2009): Epiphytic bacteria and yeasts on apple blossoms and their potential as antagonists of Erwinia amylovora. Phytopathology 99: 571-581.

Putnoky, P., Hoffmann, Gy. (2007): Bevezetés a genetikába. Baktérium és fággenetika I. http://ttk.pte.hu/biologia/genetika/atg/chap10/ch10a.htm.

Rao, Y.P., Srivastava, D.N. (1973): Application of phages in investigation of epidemiology of bacterial blight disease of rice. In: Raychandhari, S.P. (ed.) Proceedings of the Indian National Science Academy: Epidemiology, forecasting and control of plant diseases. 37: 314-321.

Ravensdale, M., Blom, T.J., Gracia-Garza, J.A., Svircev, A.M., Smith, R.J. (2007): Bacteriophages and the control of Erwinia carotovora subsp. carotovora. Can J Plant Pathol 29: 121-130.

Reynoird, J.P., Mourgues, F., Norelli, J.L., Aldwinckle, H.S., Brisset, M.N., Chevreau, E. (1999): First evidence for differences in fire blight resistance among transgenic pear clones expressing attacin gene. Plant Sci 149: 23-31.

Rezzonico, F., Smits, T.H.M., Montesinos, E., Frey, J.E., Duffy, B. (2009a): Genotypic comparison of Pantoea agglomerans plant and clinical strains to address biosafety and taxonomic issues. BMC Microbiol 9: 204. 
Rezzonico, F., Stockwell, V.O., Duffy, B. (2009b): Plant agricultural streptomycin formulations do not carry antibiotic resistance genes. Antimicrob Agents Chemother 53: 3173-3177.

Ritchie, D.E., Klos, E.J. (1977): Isolation of Erwinia amylovora bacteriophage from aerial parts of apple trees. Phytopathology 67: 101-104.

Ritchie, D.E., Klos, E.J. (1979): Some properties of Erwinia amylovora bacteriophages. Phytopathology 69: 1078-1083.

Roach, D.R., Castle, A.J., Svircev, A.M., Tumini, F.A. (2008): Phage-based biopesticides characterization of phage resistance and host range for sustainability. Acta Hortic 793: 397-401.

Roach, D.R., Sjaarda, D., Castle, A.J., Svircev, A.M. (2011): Bacteriophages as biopesticides: role of bacterial exopolysaccharides. Acta Hortic 896: 449-455.

Rosen, H.R. (1938): Life span and morfology of fire blight bacteria as infuenced by relative humidity, temperature and nutrition. J Agric Res 56: 239-258.

Rosen, H.R., Groves, A.B. (1928): Studies on fire blight: host range. J Agric Res 37: 493-505.

Roemmelt, S., Plagge, J., Treutter, D., Zeller, W. (1999): Fire blight control in apple using products based on mineral powders. Acta Hortic 489: 623-624.

Saccardi, A., Gambin, E., Zaccardelli, M., Barone, G., Mazzucchi, U. (1993): Xanthomonas campestris pv. pruni control trials with phage treatments on peaches in the orchard. Phytopathol Mediterr 32: 206-210.

Salm, H., Geider, K. (2004): Real-time PCR for detection and quantification of Erwinia amylovora, the causal agent of fireblight. Plant Pathol 53: 602-610.

Schaad, N.W., Jones, J.B., Chun, W. (2001): Laboratory Guide for Identification of Plant Pathogenic Bacteria, Third Edition. American Phytopathological Society Press, St Paul, USA.

Schatz, A., Bugie, E., Waksman, S.A. (1944): Streptomycin, a substance exhibiting antibiotic activity against Gram-positive and Gram-negative bacteria. P Soc Exp Biol Med 55: 66-69.

Schnabel, E.L., Fernando, W.G.D., Meyer, M.P., Jones, A.L., Jackson, L.E. (1999): Bacteriophage of Erwinia amylovora and their potential for biocontrol. Acta Hortic 489: 649654.

Schnabel, E.L., Jones, A.L. (2001): Isolation and characterization of five Erwinia amylovora bacteriophages and assessment of phage resistance in strains of Erwinia amylovora. Appl Environ Microbiol 67: 59-64. 
Schwarczinger, I., Tóth, M., Hevesi, M. (2011): Control of fire blight by bacteriophages on apple flowers. Acta Hortic 896: 457-462.

Schwarczinger, I., Vajna, L., Süle, S. (2008): First report of bacterial leaf and flower spot of Zinnia elegans caused by Xanthomonas campestris pv. zinniae in Hungary. Plant Pathol 57: 367.

Scortichini, M., Rossi, M.P. (1989): In vitro activity of some essential oils towards Erwinia amylovora (Burill) Winslow et al. Acta Phytopathol Entomol Hung 4: 423-431.

Seemüller, E., Arnold, M. (1978): Pathogenicity, syringomycin production and other characteristics of pseudomonad strains isolated from deciduous fruit trees. Proc $4^{\text {th }}$ Int Conf Plant Pathogenic Bacteria. Angers, Franciaország, 703-710.

Seibold, A., Viehrig, M., Jelkmann, W. (2006): Yeasts as antagonists against Erwinia amylovora. Acta Hortic 704: 367-370.

Seveno, N.A., Kallifidas, D., Smalla, K., van Elsas, J.D., Collard, J.-M., Karagouni, A.D., Wellington, E.M.H. (2002): Occurrence and reservoirs of antibiotic resistance genes in the environment. Rev Med Microbiol 13: 15-27.

Severin, V., Constantinescu, F., Jianu, F. (1999): Appearance, expansion and chemical control of fire blight (Erwinia amylovora) in Romania. Acta Hortic 489: 79-84.

Shaffer, W.H., Goodman, R.N. (1985): Appearance of streptomycin-resistant Erwinia amylovora in Missouri apple orchards. Phytopathology 75: 1281.

Singh, A., Arutyunov, D., Szymanski, C.M., Evoy, S. (2012): Bacteriophage based probes for pathogen detection. Analyst 137: 3405-3421.

Smith, G.P. (1985): Filamentous fusion phage: novel expression vectors that display cloned antigens on the virion surface. Science 228: 1315-1317.

Smith, T.J. (1993): A predictive model for forecasting fire blight of pear and apple in Washington State. Acta Hortic 338: 153-157.

Sobiczewski, P., Deckers, T., Pulawska, J. (1997): Fire blight (Erwinia amylovora), some aspects of epidemiology and control. Research Institute of Pomology and Floriculture, Poland 43-46.

Staphorst, J.L., van Zyl, F.G.H., Strijdom, B.W., Groenewold, Z.E. (1985): Agrocinproducing pathogenic and nonpathogenic biotype 3 strains of Agrobacterium tumefaciens active against biotype 3 pathogens. Curr Microbiol 12: 45-52. 
Starr, M.P., Cardona, C., Folsom, D. (1951): Bacterial fire blight of raspberry. Phytopathology 41: 915-919.

Steinberger, E.M., Beer, S.V. (1988): Creation and complementation of pathogenicity mutants of Erwinia amylovora. Mol Plant Microbe Interact 1: 135-144.

Steiner, P.W. (1990): Predicting apple blossom infection by Erwinia amylovora using the MARYBLYT model. Acta Hortic 273: 139-146.

Steiner, P.W. (2000): Integrated orchard and nursery management for the control of fire blight. In: Vanneste, J.L. (ed.) Fire blight: the disease and its causative agent, Erwinia amylovora. CABI Publishing, Wallingford, UK, 339-358.

Stockwell, V.O., Duffy, B. (2012): Use of antibiotics in plant agriculture. Rev Sci Tech Oie 31: 199-210.

Stockwell, V.O., Johnson, K.B., Sugar, D., Loper, J.E. (2002): Antibiosis contributes to biological control of fire blight by Pantoea agglomerans strain Eh252 in orchards. Phytopathology 92: 1202-1209.

Stockwell, V.O., Johnson, K.B., Sugar, D., Loper, J.E. (2010): Control of fire blight by Pseudomonas fluorescens A506 and Pantoea vagans C9-1 applied as single strains and mixed inocula. Phytopathology 100: 1330-1339.

Sulakvelidze, A., Alavidze, Z., Morris, J.G. (2001): Bacteriophage therapy. Antimicrob Agents Ch 14: 649-659.

Summers, W.C. (1999): Bacteriophage discovered. In: Summers, W.C. (ed.) Felix d'Herelle and the Origins of Molecular Biology. Yale University Press, USA, 47-59.

Summers, W.C. (2001): Bacteriophage therapy. Ann Rev Microbiol 55: 437-451.

Summers, W.C. (2005): Bacteriophage research: Early history. In: Kutter, E., Sulakvelidze, A. (eds.) Bacteriophages: Biology and Applications. CRC Press, Boca Raton, FL, 5-27.

Sundin, G.W., Werner, N.A., Yoder, K.S., Aldwinckle, H.S. (2009): Field evaluation of biological control of fire blight in the eastern United States. Plant Dis 93: 986-994.

Süle, S., Kiss, E., Kim, W.S., Geider, K. (2002): Transformation of SR1 tobacco and JTE-H apple rootstock with the EPS-depolymerase gene from Erwinia amylovora phage. Acta Hortic 590: 407-409.

Svircev, A.M., Castle, A.J., Lehman, S.M. (2010): Bacteriophages for control of phytopathogens in food production system. In: Sabour, P.M., Griffith, M.W. (eds.) 
Bacteriophages in the Control of Food- And Waterborne Pathogens. ASM Press, Washington DC, USA, 79-103.

Svircev, A.M., Lehman, S.M., Kim, W.S., Barszcz, E., Schneider, K.E., Castle, A.J. (2006): Control of the fire blight pathogen with bacteriophages. In: Zeller, W., Ullrich, C. (eds.) Proceedings of the $1^{\text {st }}$ International Symposium on Biological Control of Bacterial Plant Diseases. Arno Brynda, Berlin, Germany, 259-261.

Sykes, I.K., Lanning, S., Williams, S.T. (1981): The effect of pH on soil actinophage. J Gen Microbiol 122: 271-280.

Takács, F. (2013): Az Erwinia amylovora (Burr.) Winslow et al. elleni küzdelem helyzete és lehetöségei Magyarországon. Növényvédö Mérnöki és Növényorvosi Kamara, VII. Növényorvosi Nap 114-115.

Tanaka, H., Negishi, H., Maeda, H. (1990): Control of tobacco bacterial wilt by an avirulent strain of Pseudomonas solanacearunm M4S and its bacteriophage. Ann Phytopathol Soc Jpn 56: 243-246.

Taylor, A.L. (1963): Bacteriophage-induced mutation in E. coli. Proc Natl Acad Sci USA 50: 1043-1051.

Tharaud, M., Laurent, J., Faize, M., Paulin, J.-P. (1997): Fire blight protection with avirulent mutants of Erwinia amylovora. Microbiology 143: 625-632.

Tharaud, M., Menggad, M., Paulin, J.-P., Laurent, J. (1994): Virulence, growth, and surface characteristics of Erwinia amylovora mutants with altered pathogenicity. Microbiology 140: 659669.

Thomson, S.V. (1986): The role of stigma in fire blight infections. Phytopathology 76: 476-482.

Thomson, S.V. (2000): Epidemiology of fire blight In: Vanneste, J.L. (ed.) Fire blight: the disease and its causative agent, Erwinia amylovora. CABI Publishing, Wallingford, UK, 9-35.

Thomson, S.V., Gouk, S.C., Vanneste, J.L., Hale, C.N., Clark, R.G. (1993): The presence of streptomycin resistant strains of Erwinia amylovora in New-Zealand. Acta Hortic 338: 223-230.

Tóth, M. (2005): Six promising selections from the Hungarian apple breeding program for multiple resistance. Int J Hortic Science 11: 23-28.

Tóth, M., Ficzek, G., Király, I., Kovács, Sz., Hevesi, M., Halász, J., Szani, Zs. (2012): 'Artemisz', 'Cordelia', 'Hesztia', and 'Rosmerta': New Hungarian multiresistant apple cultivars. HortScience 47: 1795-1800. 
Tóth, M., Hevesi, M., Honty, K., Kása, K. (2005): A Kárpátalján fellelhető alma genotípusok (régi és helyi fajták) tüzelhalással szembeni ellenállósága növényházi vizsgálatok alapján. Növényvédelem 41: 341-348.

Trevisan, V. (1889): Bacilli endofitobii destruenti. His I Generi e le Specie delle Batteriacea, Milano, 19.

Twort, F.W. (1915): An investigation on the nature of ultra-microscopic viruses. Lancet 186: 1241-1243.

Uyeda, E. (1903): The causal bacterium of apple blight. Dai-Nippon No-Kaiho 260, 1-3.

van der Zwet, T. (2006): Present worldwide distribution of fire blight and closely related diseases. Acta Hortic 704: 35-36.

van der Zwet, T., Keil, H.M. (1979): Fire Blight - A bacterial disease of Rosaceous plants. Agriculture Handbook 510. US Department of Agriculture, Washington DC, USA, 1-200.

Vanneste, J.L. (1995): Erwinia amylovora. In: Singh, U.S., Singh, R.P., Hohmoto, K. (eds.) Pathogenesis and host specificity in plant diseases: histopathological, biochemical, genetic and molecular bases I. Prokaryotes. Pergamon Press, Oxford, London, UK, 21-41.

Vanneste, J.L. (2006): Biological control of fire blight: an overview of the work carried out in New Zealand. Proceedings of the $1^{\text {st }}$ International symposium on biological control of bacteria plant disease 408: 224-227.

Vanneste, J.L. (2011): Biological control agents of fire blight: successes and challenges. Acta Hortic 896: 409-416.

Vanneste, J.L., Eden-Green, S. (2000): Migration of Erwinia amylovora in host plant tissues. In: Vanneste, J.L. (ed.) Fire blight: the disease and its causative agent, Erwinia amylovora. CABI Publishing, Wallingford, UK, 73-85.

Vanneste, J.L., Lex, S., Vermeulen, M., Berger, F. (2002): Isolation of Erwinia amylovora from blighted plums (Prunus domestica) and potato roses (Rosa rugosa). Acta Hortic 590: 8994.

Végh, A. (2012): Az almafélék tüzelhalását okozó Erwinia amylovora hazai izolátumainak biológiai változatossága. Doktori (PhD) értekezés. Budapesti Corvinus Egyetem, Budapest, Magyarország.

Végh, A., Hevesi, M., Pájtli, É., Petrik, K., Palkovics, L. (2014): Hazai Erwinia amylovora izolátumok összehasonlítása molekuláris vizsgálat alapján. 60. Növényvédelmi Tudományos Napok. 2014. február 18-19., Budapest, Magyarország. Absztrakt: 108. 
Végh, A., Horváth, B., Hevesi, M., Schwarczinger, I., Palkovics, L. (2012c): Bakteriofágok hatásának vizsgálata Erwinia amylovora izolátumokra. Növényvédelem 48: 559-567.

Végh, A., Némethy, Zs., Hajagos, L., Palkovics, L. (2012a): First report of Erwinia amylovora causing fire blight on plum (Prunus domestica L.) in Hungary. Plant Dis 96: 5, 759.

Végh, A., Némethy, Zs., Hajagos, L., Palkovics, L. (2012b): Új gazdanövényen (Prunus domestica L. 'D' Agen') jelent meg az Erwinia amylovora Magyarországon. Növényvédelem 48: 378-382.

Végh, A., Palkovics, L. (2013): First occurence of fire blight on apricot (Prunus armeniaca) in Hungary. Not Bot Horti Agrobo 41: 440-443.

Ward, R.L., Mahler, R.J. (1982): Uptake of bacteriophage f2 through plant roots. Appl Environ Microbiol 43: 1098-1103.

Wilson, M., Epton, H.A.S., Sigee, D.C. (1992): Interactions between Erwinia herbicola and E. amylovora on the stigma of hawthorn blossoms. Phytopathology 82: 914-918.

Winslow, C.E.A., Broadhurst, J., Buchanan, R.E., Krumwiede, Jr. C., Rogers, L.A., Xue, M.Q., Black, L.W. (1920): Role of the major capsid protein of phage T4 in DNA packaging from structure-function and site-directed mutagenesis studies. J Struct Biol 104: 75-83.

Xue, M.Q., Black, L.W. (1990): Role of the major capsid protein of phage T4 in DNA packaging from structure-function and site-directed mutagenesis studies. J Struct Biol 104: 7583.

Yashiro, E., McManus, P.S. (2012): Effect of streptomycin treatment on bacterial community structure in the apple phyllosphere. PLoS One 7: e37131.

Zeller, W. (2006): Status of biocontrol methods against fire blight. Phytopathol Pol 39: 71-78. 


\section{MELLÉKLETEK}

M1.a Az EaFF/R primerpárral kapott PCR termékek (677bp) gélelektroforézis fotója

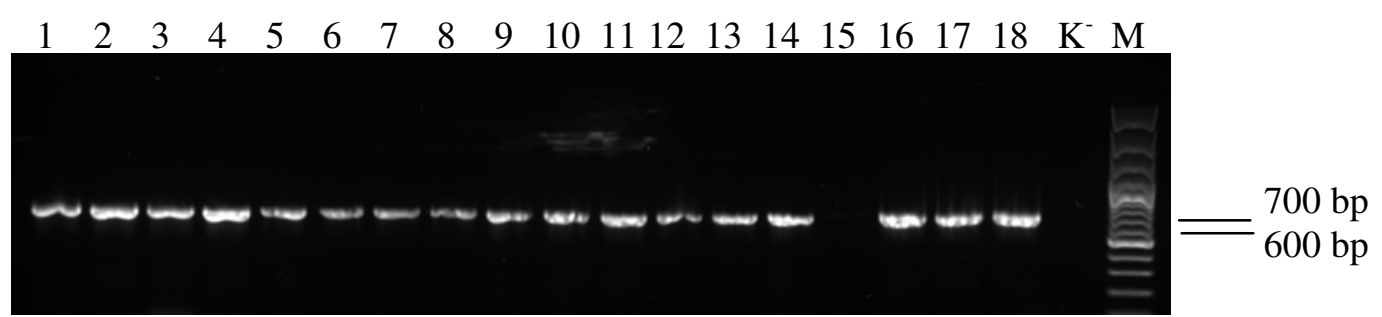

A minták balról jobbra: H1A, H1B, H2A, H2B, H4A, H4B, H5K, H5A, H5B, H6B, H7B, H7A, H8A, H8B, H9A, H9B, H10A, H10B, víz (K), GeneRuler ${ }^{\text {TM }} 100$ bp DNA Ladder Plus (Thermo Scientific) (M).

M1.b Az EaFF/R primerpárral kapott PCR termékek (677bp) gélfotója (folyt.)

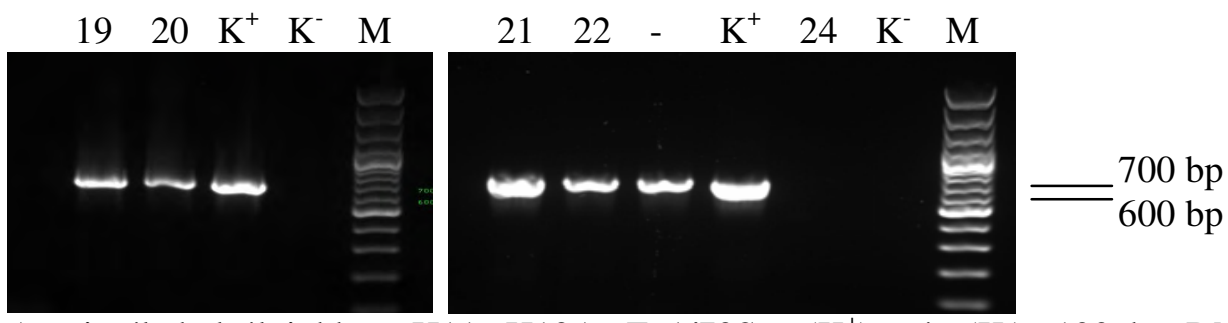

A minták balról jobbra: H11, H12A, Ea1/79Sm $\left(\mathrm{K}^{+}\right)$, víz $\left(\mathrm{K}^{-}\right), 100$ bp DNA Ladder Plus (Thermo

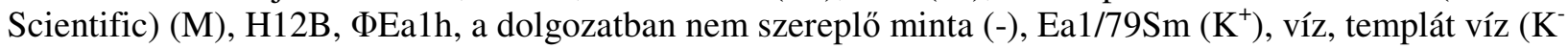
), 100 bp DNA Ladder Plus (Thermo Scientific) (M).

M2.a Az 1hcapF/R primerpárral kapott PCR termékek (474bp) gélelektroforézis fotója

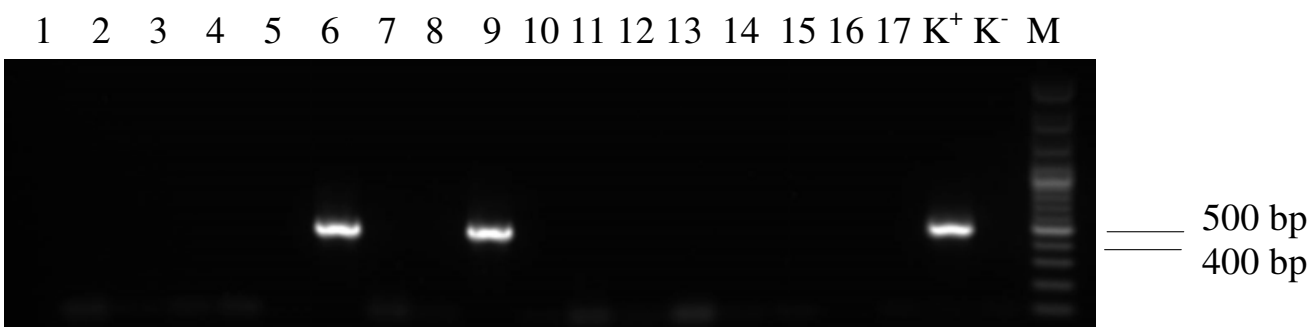

A minták balról jobbra: H1A, H1B, H2A, H2B, H4A, H4B, H5K, H5A, H5B, H6B, H7B, H7A, H8A, H8B, H9A, H9B, H10A, ФEa1h $\left(\mathrm{K}^{+}\right)$, víz $\left(\mathrm{K}^{-}\right)$, GeneRuler ${ }^{\mathrm{TM}} 100$ bp DNA Ladder Plus (Thermo Scientific) (M).

M2.b Az 1hcapF/R primerpárral kapott PCR termékek (474bp) gélelektroforézis fotója (folyt.)

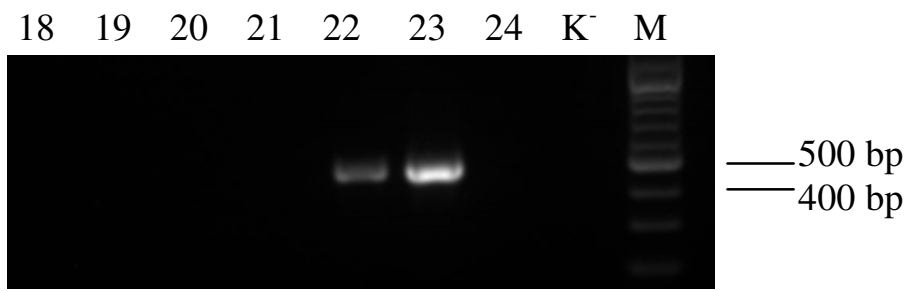

A minták balról jobbra: H10B, H11, H12A, H12B, ФEa1h, ФEa104, víz, templát víz (K), GeneRuler ${ }^{\top M}$ 100 bp DNA Ladder Plus (Thermo Scientific) (M). 
M3. Az Ea104F/R primerpárral kapott PCR termékek (665bp) gélfotója

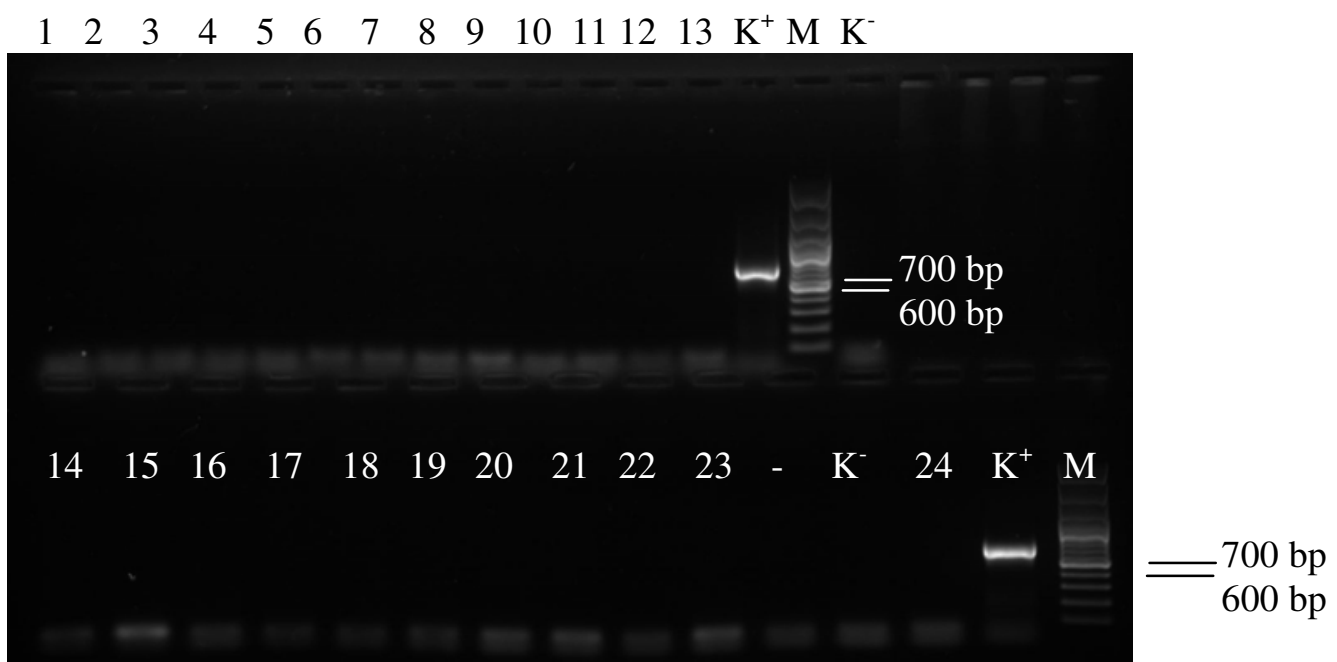

A minták balról jobbra (1. sor): H1A, H1B, H2A, H2B, H4A, H4B, H5K, H5A, H5B, H6B, H7B, H7A, H8A, ФEa104 (K $\mathrm{K}^{+}$), GeneRuler ${ }^{\mathrm{TM}} 100$ bp DNS Ladder Plus (Thermo Scientific) (M), víz (K'). A második sorban a minták balról jobbra: H8B, H9A, H9B, H10A, H10B, H11, H12A, H12B, ФEa1h, ФEa100, a dolgozatban nem szereplő Ea törzs (-), víz (K), ФEa116, ФEa104 (K $\left.{ }^{+}\right)$, GeneRuler ${ }^{\mathrm{TM}} 100$ bp DNA Ladder Plus (Thermo Scientific) (M).

M4.a Az Ea100F/R primerpárral kapott PCR termékek (344bp) gélfotója

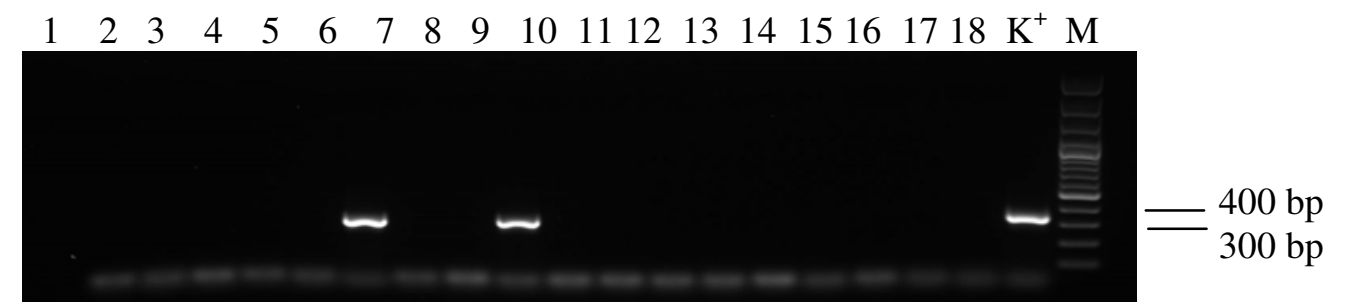

A minták balról jobbra: H1A, H1B, H2A, H2B, H4A, H4B, H5K, H5A, H5B, H6B, H7B, H7A, H8A, H8B, H9A, H9B, H10A, H10B, ФEa1h $\left(\mathrm{K}^{+}\right)$, GeneRuler ${ }^{\mathrm{T}} 100$ bp DNS Ladder Plus (Thermo Scientific) (M).

M4.b Az Ea100F/R primerpárral kapott PCR termékek (344bp) gélfotója (folyt.)

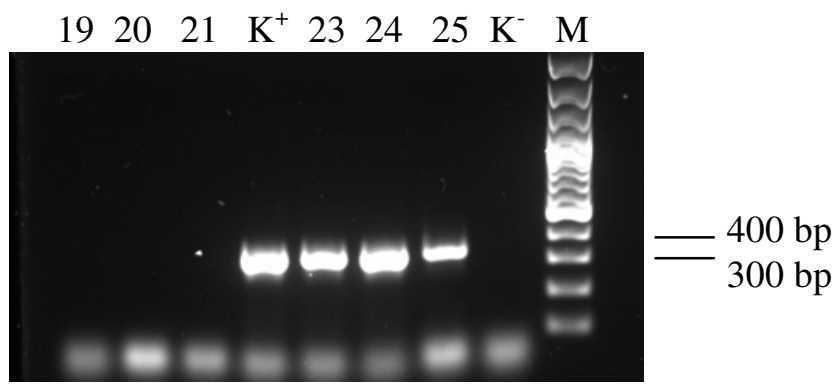

A minták balról jobbra: H11, H12A, H12B, ФEa100 (K+), ФEa104, ФEa104, ФEa116, víz (K), GeneRuler $^{\text {TM }} 100$ bp DNA Ladder Plus (Thermo Scientific) (M). 
M5. A PEa1A/B primerpárral kapott PCR termékek (304bp) gélfotója

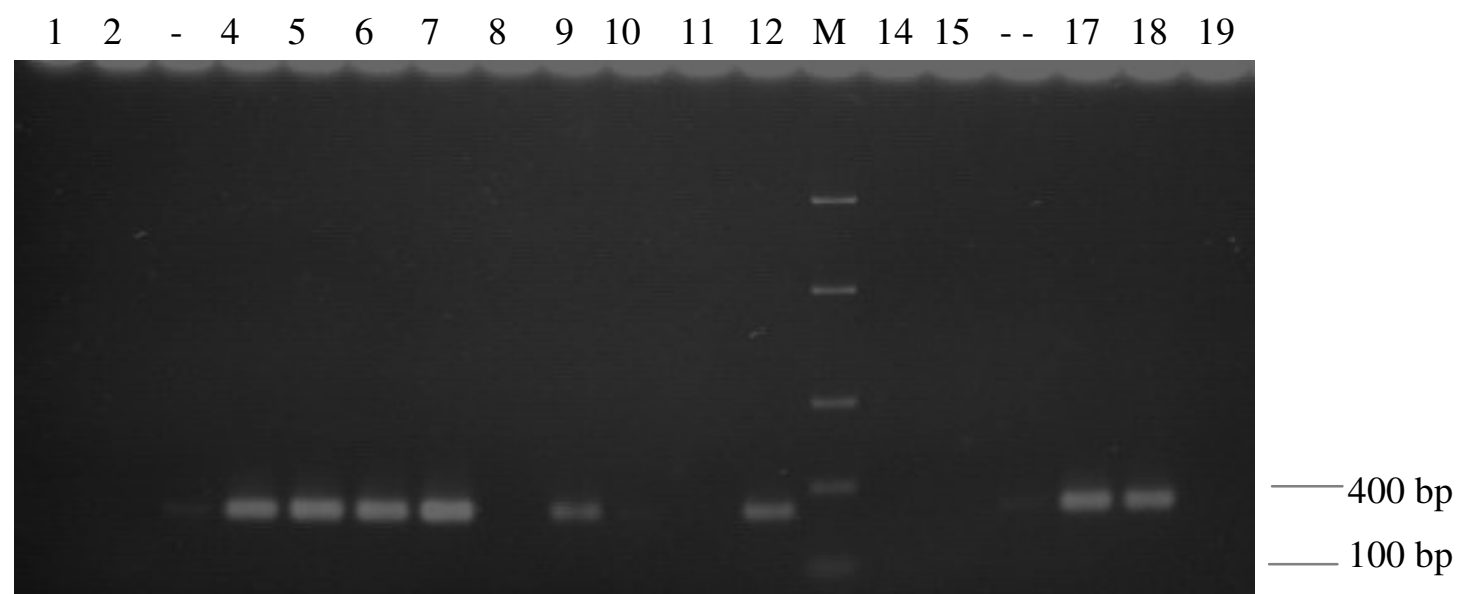

A minták balról jobbra: H1B, H2B, a dolgozatban nem szereplő minta (-), H4B, H5B, H7A, H6B, H8A, H9B, H10B, H11, H12B, FastRuler ${ }^{\text {TM }}$ Middle Range DNA Ladder (Thermo Scientific) (M), H1A, H2A, a dolgozatban nem szereplö minta (--), H4A, H5A, H7B.

M6. Magyar fágizolátumok Dpo-1/2c primerpárral kapott PCR termékeinek (1006bp) gélfotója $\begin{array}{lllllllllllllllllll}1 & 2 & 3 & 4 & - & - & 7 & 8 & 9 & 10 & 11 & 12 & 13 & 14 & 15 & 16 & 17 & 18 & \mathrm{M}\end{array}$

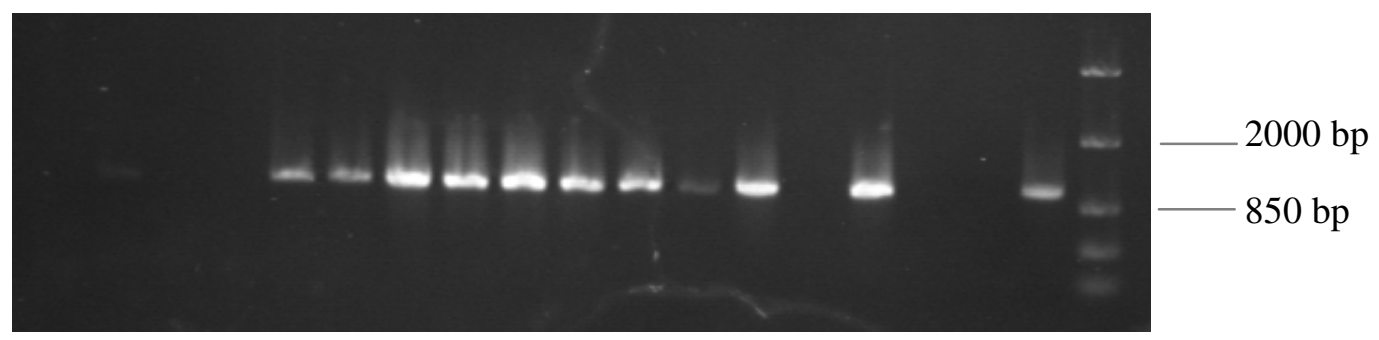

A minták balról jobbra: H1A, H1B, H2A, H2B, a dolgozatban nem szereplő minták (-) és (- -), H4A,

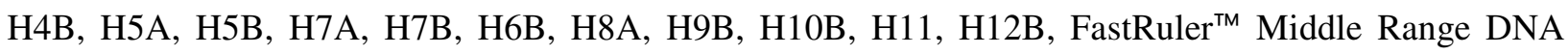
Ladder (Thermo Scientific) (M).

M7. Magyar fágizolátumok Hol-F/R primerpárral kapott PCR termékeinek (361bp) gélfotója

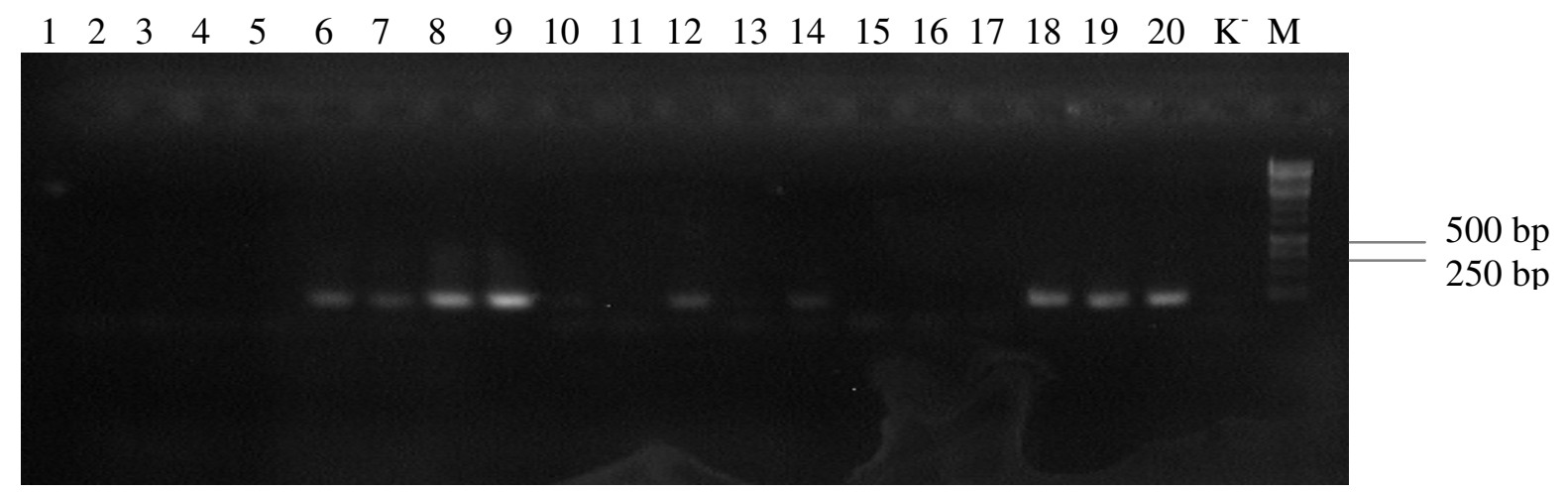

A minták balról jobbra: H1A, H1B, H2A, H2B, H4A, H4B, H5A, H5B, H7A, H7B, H6B, H8A, H9B, H10B, H11, H12B, ФEa1h, ФEa100, ФEa104, ФEa116, víz (K'), GeneRuler ${ }^{\top M} 1$ kb DNA Ladder Plus (Thermo Scientific) (M). 
M8. Magyar fágizolátumok Lys-F/R primerpárral kapott PCR termékeinek (537bp) gélfotója

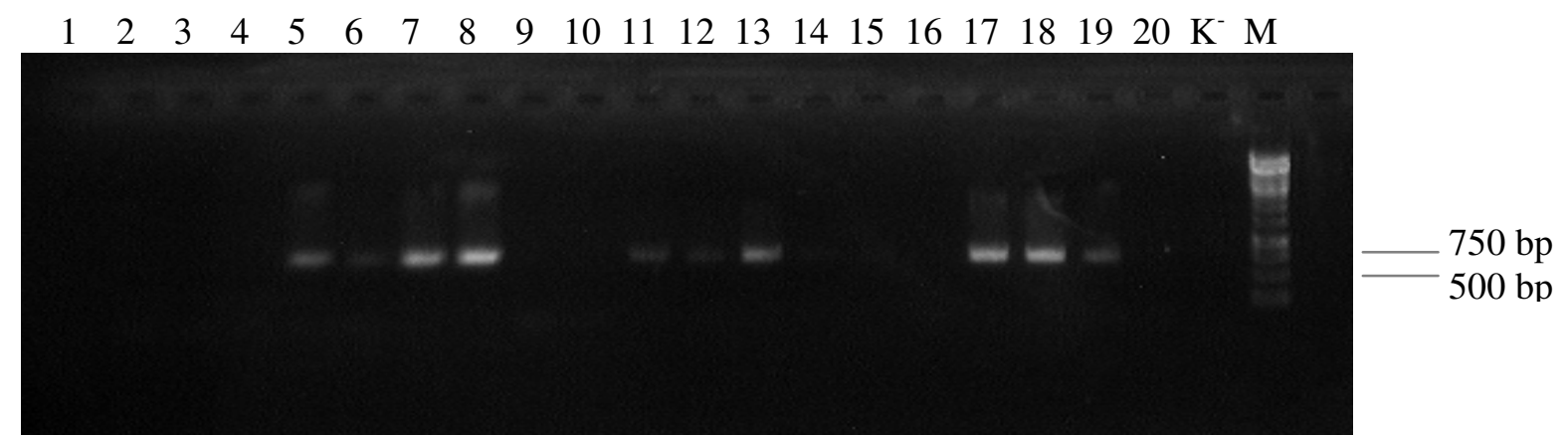

A minták balról jobbra: H1A, H1B, H2A, H2B, H4A, H4B, H5A, H5B, H7A, H7B, H6B, H8A, H9B, H10B, H11, H12B, ФEa1h, ФEa100, ФEa104, ФEa116, víz (K'), GeneRuler ${ }^{\top \mathrm{M}} 1$ kb DNA Ladder Plus (Thermo Scientific) (M).

M9. Magyar fágizolátumok Term-F/R primerekkel kapott PCR termékeinek (1079bp) gélfotója

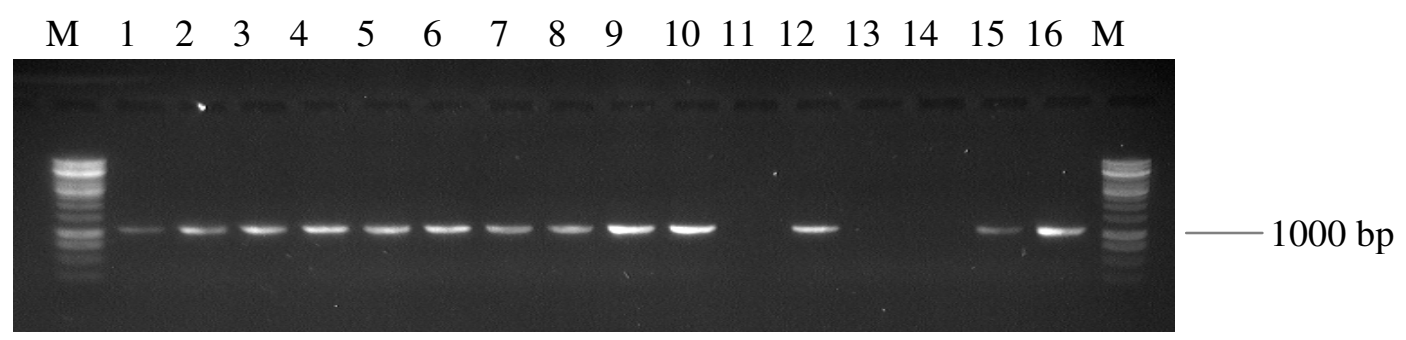

A minták balról jobbra: GeneRuler ${ }^{\mathrm{TM}} 1 \mathrm{~kb}$ DNA Ladder Plus (Thermo Scientific) (M), H1A, H1B, H2A, H2B, H7A, H7B, H6B, H8A, H9B, H10B, H11, H12B, ФEa1h, ФEa100, ФEa104, ФEa116, GeneRuler ${ }^{\mathrm{TM}}$ 1 kb DNA Ladder Plus (Thermo Scientific) (M).

M10. Magyar fágizolátumok Pep-F/R primerekkel kapott PCR termékeinek (500bp) gélfotója

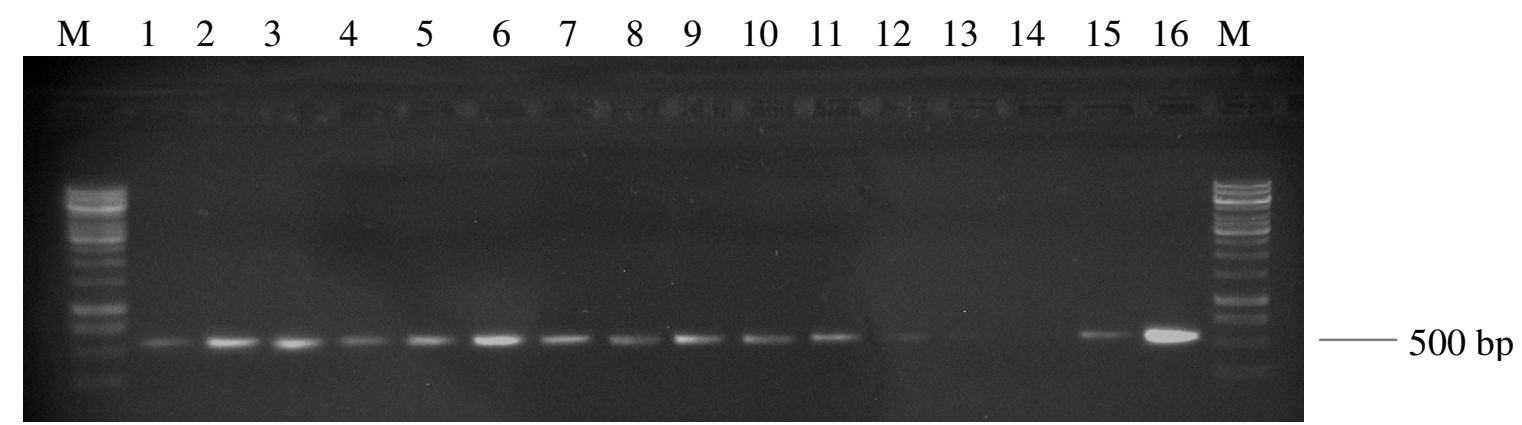

A minták balról jobbra: GeneRuler ${ }^{\mathrm{TM}} 1 \mathrm{~kb}$ DNA Ladder Plus (Thermo Scientific) (M), H1A, H1B, H2A, H2B, H4A, H7A, H7B, H8A, H9B, H10B, H11, H12B, ФEa1h, ФEa100, ФEa104, ФEa116, GeneRuler ${ }^{\text {TM }}$ 1 kb DNA Ladder Plus (Thermo Scientific) (M). 
M11. Magyar fágizolátumok Mu-F/R primerpárral kapott PCR termékeinek (614bp) gélfotója

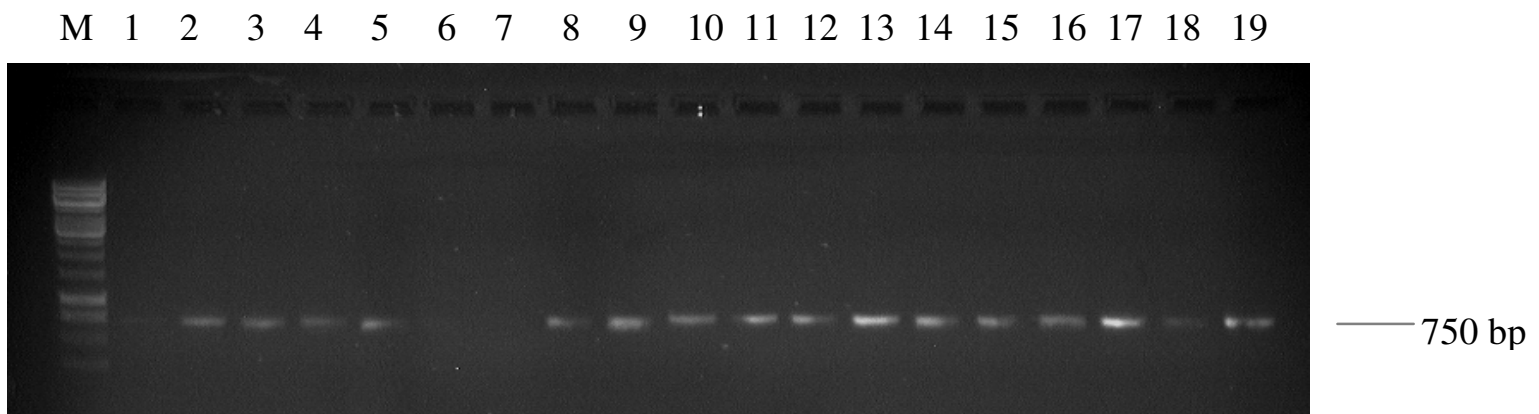

A minták balról jobbra: GeneRuler ${ }^{\mathrm{TM}} 1 \mathrm{~kb}$ DNA Ladder Plus (Thermo Scientific) (M), H1A, H1B, H2A, H2B, H4A, H4B, H5A, H5B, H7A, H7B, H8A, H9B, H10B, H11, H12B, ФEa1h, ФEa100, ФEa104, ФEa116.

M12.a Magyar fágizolátumok [H5K (1), H8B (2), H9A (3), H10A (4), H12A (5)] PEa1A/B (P) (304 bp), Dpo-1/2c (D) (1006 bp), Hol-F/R (H) (361 bp) és Lys-F/R (L) (537 bp) primer párokkal végzett PCR eredménye

$\begin{array}{llllllllllllllllll}1 & 2 & 3 & 4 & 5 & 6 & 7 & 8 & 9 & 10 & 11 & 12 & 13 & 14 & 15 & 16 & 17 & \mathrm{~K}^{+} \\ \mathrm{K}^{-} \mathrm{M}\end{array}$

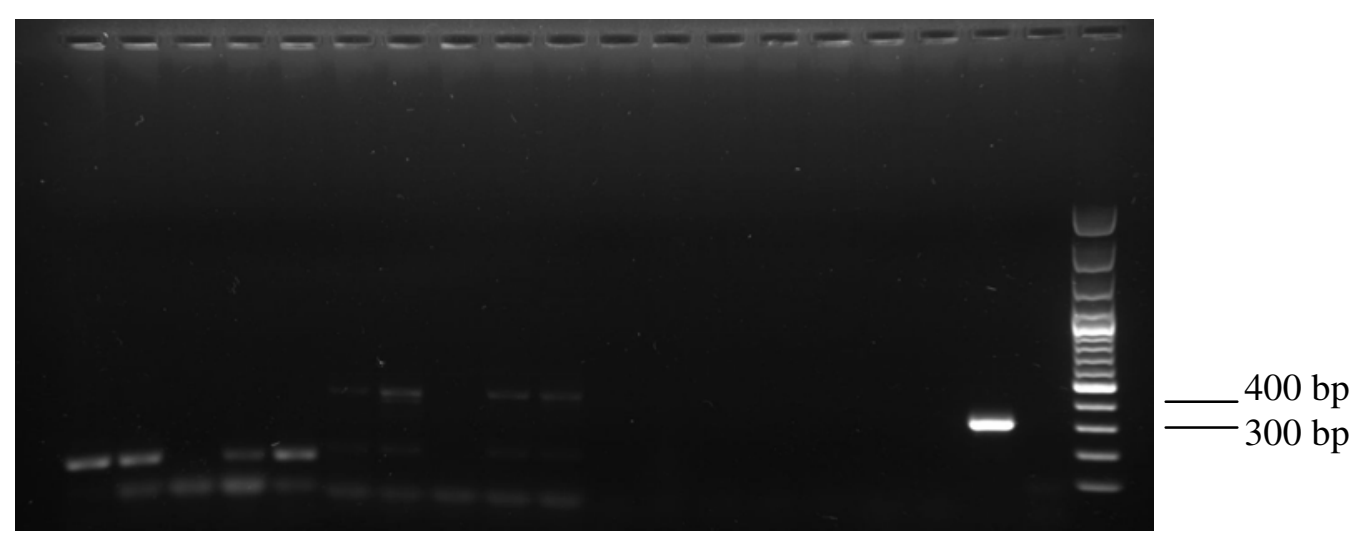

A minták balról jobbra: P1, P2, P3, P4, P5, D1, D2, D3, D4, D5, H1, H2, H3, H4, H5, L1, L2, ФEa1h (PEa1A/B) $\left(\mathrm{K}^{+}\right)$, víz ( $\left.\mathrm{K}^{-}\right)$, GeneRuler ${ }^{\mathrm{TM}} 100$ bp DNA Ladder Plus (Thermo Scientific) (M).

M12.b Magyar fágizolátumok [H5K (1), H8B (2), H9A (3), H10A (4), H12A (5)] Lys-F/R (L) (537 bp), Pep-F/R (500 bp) és Term-F/R (1079 bp) primer párokkal végzett PCR eredménye (folyt.)

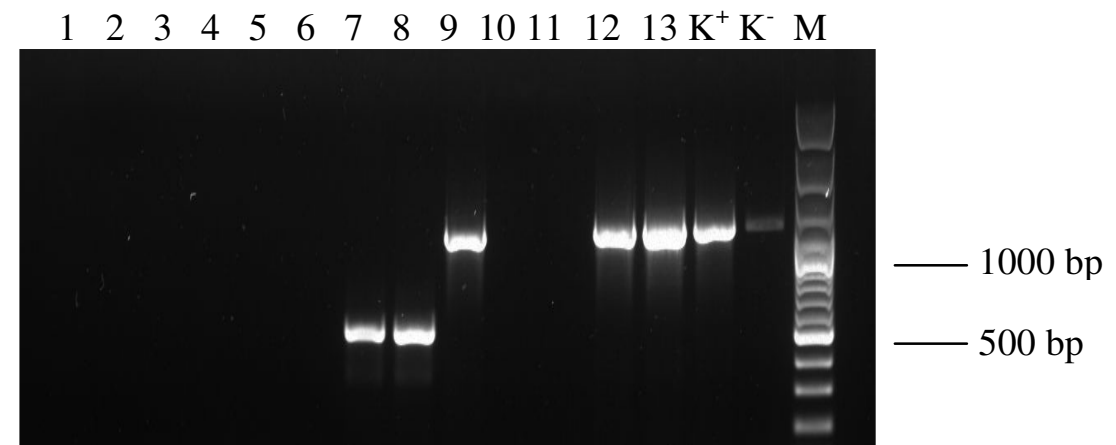

A minták balról jobbra: L3, L4, L5, Pe1, Pe2, Pe3, Pe4, Pe5, T1, T2, T3, T4, T5, ФEa116 (Term-F/R) $\left(\mathrm{K}^{+}\right)$, víz $\left(\mathrm{K}^{-}\right)$, GeneRuler ${ }^{\mathrm{TM}} 100$ bp DNA Ladder Plus (Thermo Scientific) (M). 
M12.c Magyar fágizolátumok [H5K (1), H8B (2), H9A (3), H10A (4), H12A (5)] Mu-F/R (614 bp), primer párokkal végzett PCR eredménye

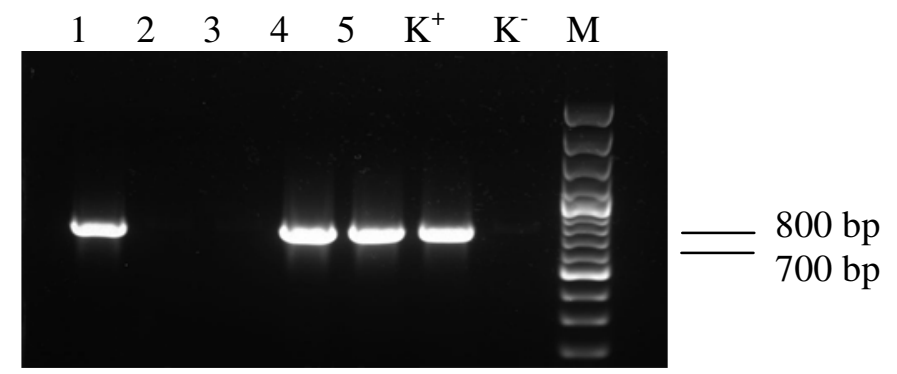

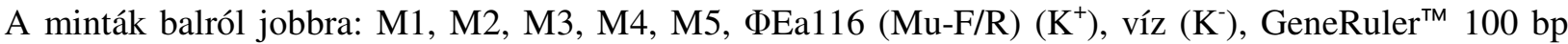
DNA Ladder Plus (Thermo Scientific) (M). 
M13. A H4A, H4B, H5A, H5B, H6A, H7A, H9B fágizolátumok Dpo-1/2c primerpárral felszaporított szakaszának szekvencia-analízise

Alignment: Global DNA alignment against reference molecule
Parameters: Scoring matrix: Linear (Mismatch 2, OpenGap 4, ExtGap 1)

Reference molecule: 50 B07 AG Geid_Ea1h_12_ju.seq, Region 1-618

Number of sequences to align: 9

Settings: Similarity significance value cutoff: $>=60 \%$

Summary of Percent Matches:

Reference: $\quad 50$ B07 AG Geid Ealh 12 ju.seg

Sequence 2: 52 D07 AG Geid 10012 ju.seq

Sequence 3: 71 G09 AG Geid 4A 12 ju.seq

Sequence 4: 72 H09 AG Geid 4B 12 ju.seg

Sequence 5: 74 B10 AG Geid 5A 12 ju.seq

Sequence 6: 75 C10 AG Geid 5B 12 ju.seq

Sequence 7: 76 D10 AG Geid 612 ju.seq

Sequence 8: 77 E10 AG Geid 7A 12 ju.seq

Sequence 9: 78_F10_AG Geid_9_12_ju.seq

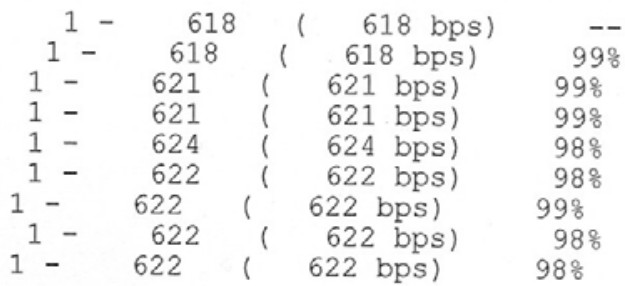

50 B07 AG Ge

52 D07 AG Ge

71 G09 AG Ge

72 H09 AG Ge

74 B10 AG Ge

75 C10 AG Ge

76 D10 AG Ge

77 E10 AG Ge

78_F10_AG Ge

50 B07 AG Ge

52 D07 AG Ge

71 G09 AG Ge

72 H09 AG Ge

74 B10 AG Ge

$75 \mathrm{C} 10 \mathrm{AG}$ Ge

76 D10 AG Ge

77 E10 AG Ge

78_F10_AG Ge

50 B07 AG Ge

52 D07 AG Ge

71 G09 AG Ge

72 H09 AG Ge

74 B10 AG Ge

75 C10 AG Ge

76 D10 AG Ge

77 E10 AG Ge

78_F10_AG Ge

50 B07 AG Ge

52 D07 AG Ge

71 G09 AG Ge

72 H09 AG Ge

74 B10 AG Ge

$75^{-} \mathrm{C} 10^{-} \mathrm{Ag}$ Ge

76 D10 AG Ge

$77^{-}$E10 AG Ge

$78^{-} \mathrm{F} 10^{-} \mathrm{AG} \mathrm{Ge}$

50 B07 AG Ge

$52^{-}$D07 AG Ge

71 G09 AG Ge

$72^{-} \mathrm{HO} 9^{-\mathrm{AG}} \mathrm{Ge}$

$74^{-}$B10 $A G$ Ge

75 C10 AG Ge

$76^{-} \mathrm{D} 10^{-A G} \mathrm{Ag}$

$77^{-} \mathrm{E} 10^{-} \mathrm{AG}$

78_F10_AG Ge
1 --CTAGG--T-CTTTGAGGG-G--GCGGCA-GTTCGCTTATGACCCTAATGACACAACCA

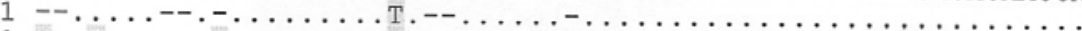

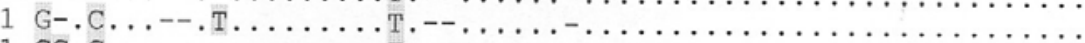

1 CG. С..--. . . .

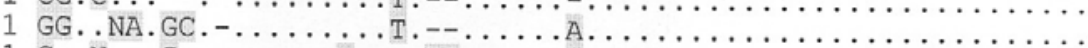

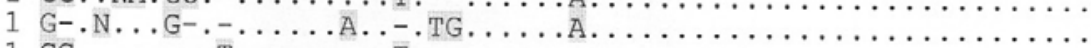

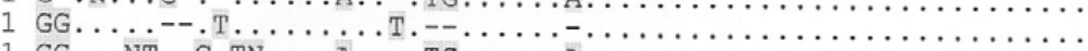

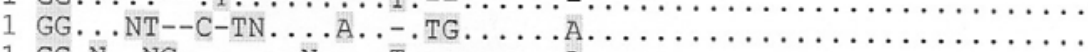

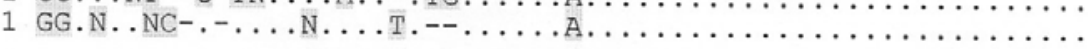

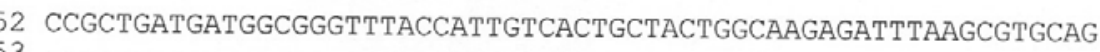
53

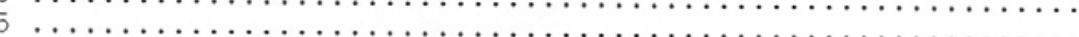

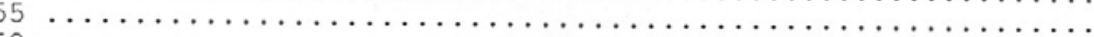

58

57

56

57

112

113

115

118

117

116.

117

117

172

173

175

175

177

176

177

177
ACCCCATCGACACCCTGGATATTACTCACTTCGGTGCGTACTGCAATGGGATTGCTGATG

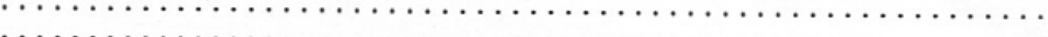

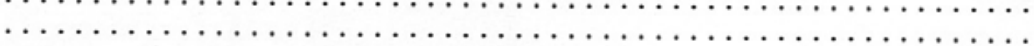

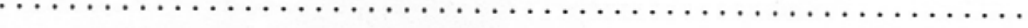
.

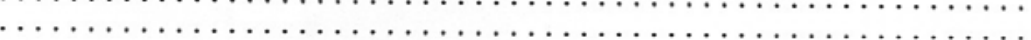

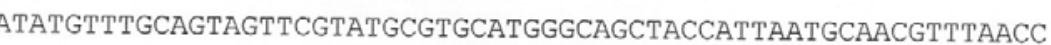

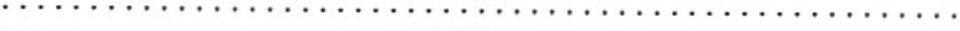

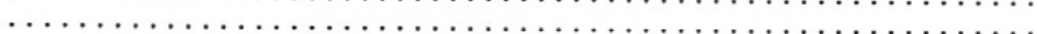

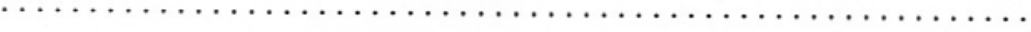

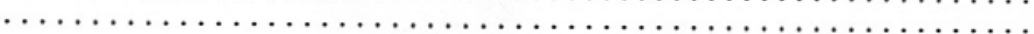

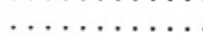

CAGGTGTGCGTATTCCATCTGGTATTACTACGCTGAGCGCTTATGACTTTGGTAGCAGTG

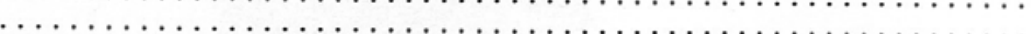

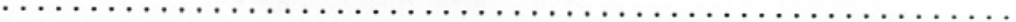

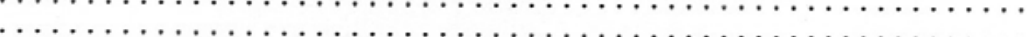

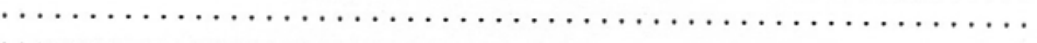


50 B07 AG Ge

52 D07 AG Ge

71 G09 AG Ge

72 H09 AG Ge

74 B10 AG Ge

75 C10 AG Ge

76 D10 AG Ge

77 E10 AG Ge

78_F10_AG Ge

50 B07 AG Ge

52 D07 AG Ge

$71 \mathrm{G} 09$ AG Ge

72 H09 AG Ge

74 B10 AG Ge

75 C10 AG Ge

76 D10 AG Ge

77 E10 AG Ge

78_F10_AG Ge

50 B07 AG Ge

52 D07 AG Ge

71 G09 AG Ge

72 H09 AG Ge

74 B10 AG Ge

75 C10 AG Ge

76 D10 AG Ge

77 E10 AG Ge

78_F10_AG Ge

50 B07 AG Ge

52 D07 AG Ge

71 G09 AG Ge

72 H09 AG Ge

74 B10 AG Ge

75 C10 AG Ge

76 D10 AG Ge

77 E10 AG Ge

78 F10_AG Ge

50 B07 AG Ge

52 D07 AG Ge

71 G09 AG Ge

72 H09 $A G$ Ge

74 B10 AG Ge

75 C10 AG Ge

76 D10 AG Ge

77 E10 AG Ge

78 F10 AG Ge

50 B07 AG Ge

52 D07 AG Ge

71 G09 AG Ge

72 H09 AG Ge

74 B10 AG Ge

$75^{-} \mathrm{C} 10^{-} \mathrm{AG} \mathrm{Ge}$

$76^{-} \mathrm{D} 10^{-A G} \mathrm{Ae}$

$77^{-} \mathrm{E} 10^{-} \mathrm{AG}$ Ge

78_F10_AG Ge
292 AgCTTCCATCGTTTAAGATTCGTGGGCCTGAAGTTGCCTATGGACGCATCCCCGCTGCAC 293

\section{GTGCATTCCATGTGTACGATACCATCGATACCGCTGTGACCCAGTGTTACTCAACCAGTG}
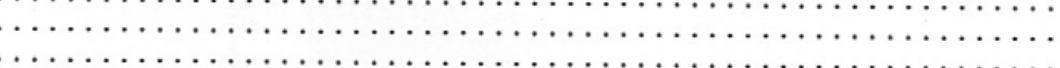

.

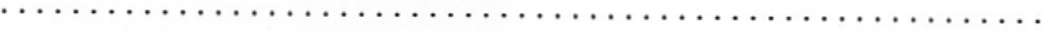

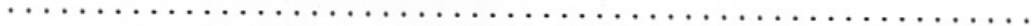

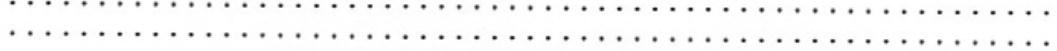

\section{GCAAGGCTTCGTTCTTCCCGTACTGAA}

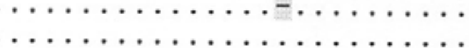

an

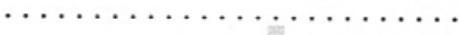

$\ldots \ldots \ldots+\cdots \cdots \cdots$

.

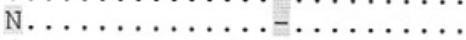


M14. A H2A Pep-F/R primerekkel kapott DNS szakaszának szekvencia-analízise

A H2A peptidázt kódoló régiójának nukleotid sorrendje

GGGGCGCTCTCTCATCGTATGTCTGGCATTGATGCAATGTGTACTGGTGGTCTGTCATCTTATCAGGGA TTGACCAGAGCATTTGATGAAGCTGTTGCTGACGCATCAGTTGAAAAGATTGTTCTGATGATTGATTCA GGTGGTGGTGAAGCTGCTGGTTGTTTCGAACTTGCAAGACACATGAAAGAACACTCTAACGGTAAACC CGTTATCGCTTATGTCGATGAAAGAGCCTGTTCAGCCGCTTATGCGCTGGCTTGTGCTGCAAGTGAAAT CTATGCCTCTCCAAATGCTGATGTAGGCTCAATTGGTGTGATTGTTATCCATCAAGAGTTCTCTAAAGC AATGGAGAAAGCGGGAATCCAAACCAACATCATCAAAGCTGGTGAAGTTAAAGGGATGGGAAACCCG TATGAACCACTTTCTGACCAAGCTAAAGACTTGATTCAGAAGTCGGTCGATAATTCTTACACATCTTTT GTCAACCTTGTATCAAGTTCT

Szekvencia összehasonlitás

Erwinia phage vB_EamM-M7, complete genome

Sequence ID: gblHQ728263.1|Length: 84694Number of Matches: 1

Range 1: 13694 to 14194GenBankGraphics Next Match Previous Match

Alignment statistics for match \#1

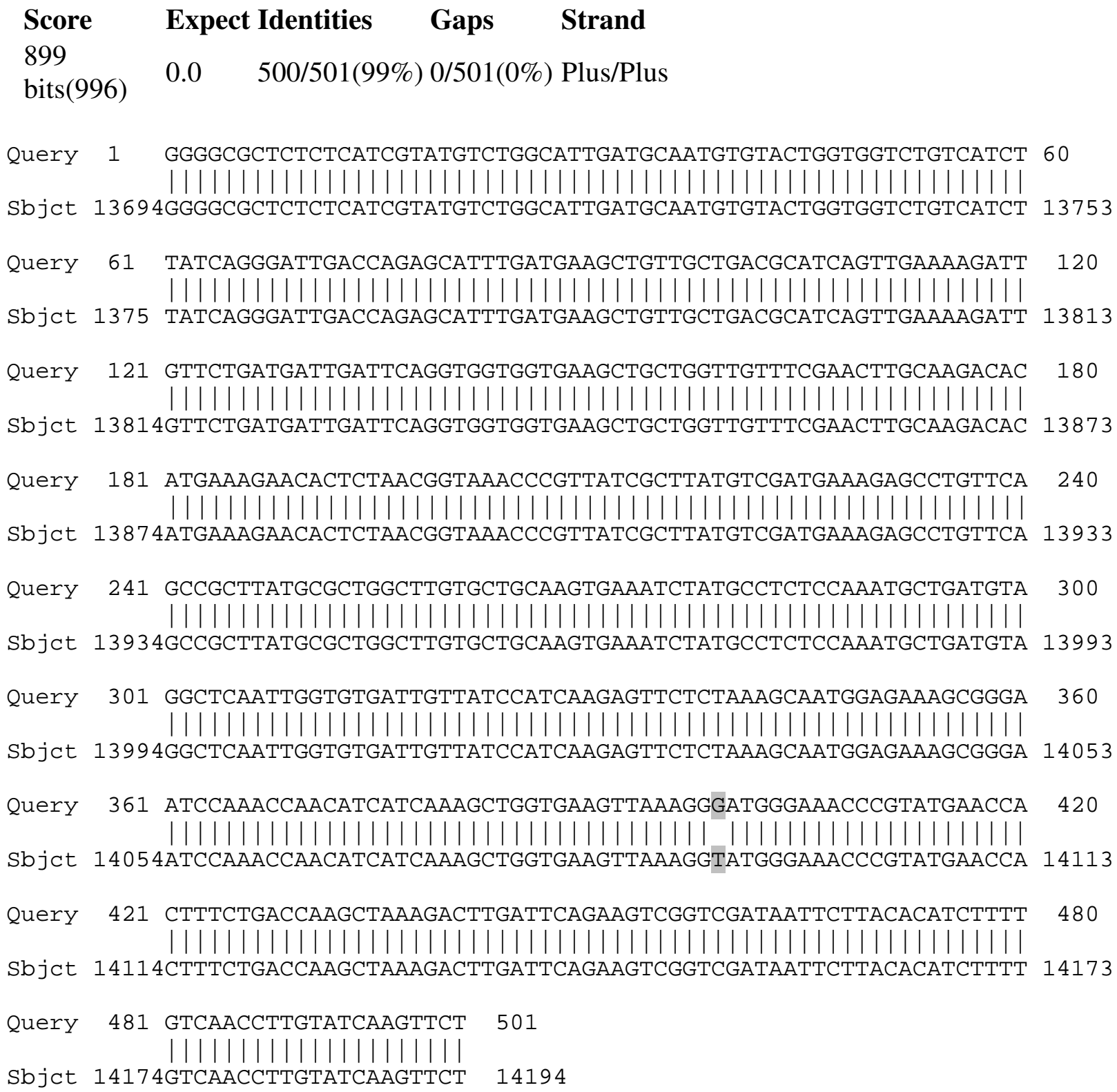


M15. A H2A fágizolátum Term-F/R primerpárral felszaporított DNS szakaszának szekvenciaanalízise

\section{A H2A terminázt kódoló szakaszának konszenzus nukleotid sorrendje}

ACCTTACCGAAGTTAAACAGCAGCGTCTGAGGGACGTACAGGCCGTTTTAGCGGGTACTATCAAACTT GAGCCAGCAGTTGTAAAACTTCTCGCCAAGTATGGAAAGCCAGTTGAAAAACTGCTTCCAAGTCAAAT CTTGACATTGAGAAAGTATACGCTTGAAGAGGTTGAACTTCTCATGAGGCTGTTGACAAATAAGAAGT TTATTGCCCCACAGCCCGGCTCTCAAGAGGCATTGCTGAACACCACAACTGACATCACACTCTATGGT GGTGCGGCTGGTTCCGGTAAGACGGTTGCTATCCTGATGGATGCCCTTCAGCATAAAGATGACCCTGA TTACTACGCTGTATTCTTCCGTAAAAACACCACACAGTTATCAGGTGGTCTTTGGCCTGCCGCTAAAAA ATTGTATGGCATGTTCGGGGGAGTTCCACATGAACAGAAGATGGTGATTCAATTCCCTTCTGGCGCAT CAATCAAGTTCTCTTACATGGAACTGGAAAAACACGCAGAAGCCCATCAGGGTATCGAATACTCAGCA ATTTATTGGGATGAGTTTACTCACTTCTCACAGAGTCAGGTTGATTACCTGATGACTCGTATGCGTTCT GGTGCAGATGGTGACTCGTACATGAAATGTTCGATGAACCCCGAAAGAGACCACTTCGTATATGCTTG GGTAGAGCCATTCCTTGATGAAGAGGGTTATCCTAATAATGAACTTTGTGGTAAGACTCGCTGGTTTGT TATTCAGGAAGGTGTCATGTATTCTGATTGGGACAGAGATGTTATTCTTCGTCAATTCCCATTAGAAAT TCCACAGACATATACCTTTATTTCTGGTACAATTGATGATAATCCAATTCTGGACTTTATCGAACCGAA ATATCGTGGTAGACTTGAAAACAATACACCTATCAACGTTGCAAGACTTCGTTATGGTAACTGGAAAG CAAGGGCTGAAGGTTCAAGCT

\section{Szekvencia összehasonlitás}

Erwinia phage vB_EamM-M7, complete genome

Sequence ID: gblHQ728263.1|Length: 84694Number of Matches: 1

Related Information

Range 1: 9589 to 10566GenBankGraphics Next Match Previous Match

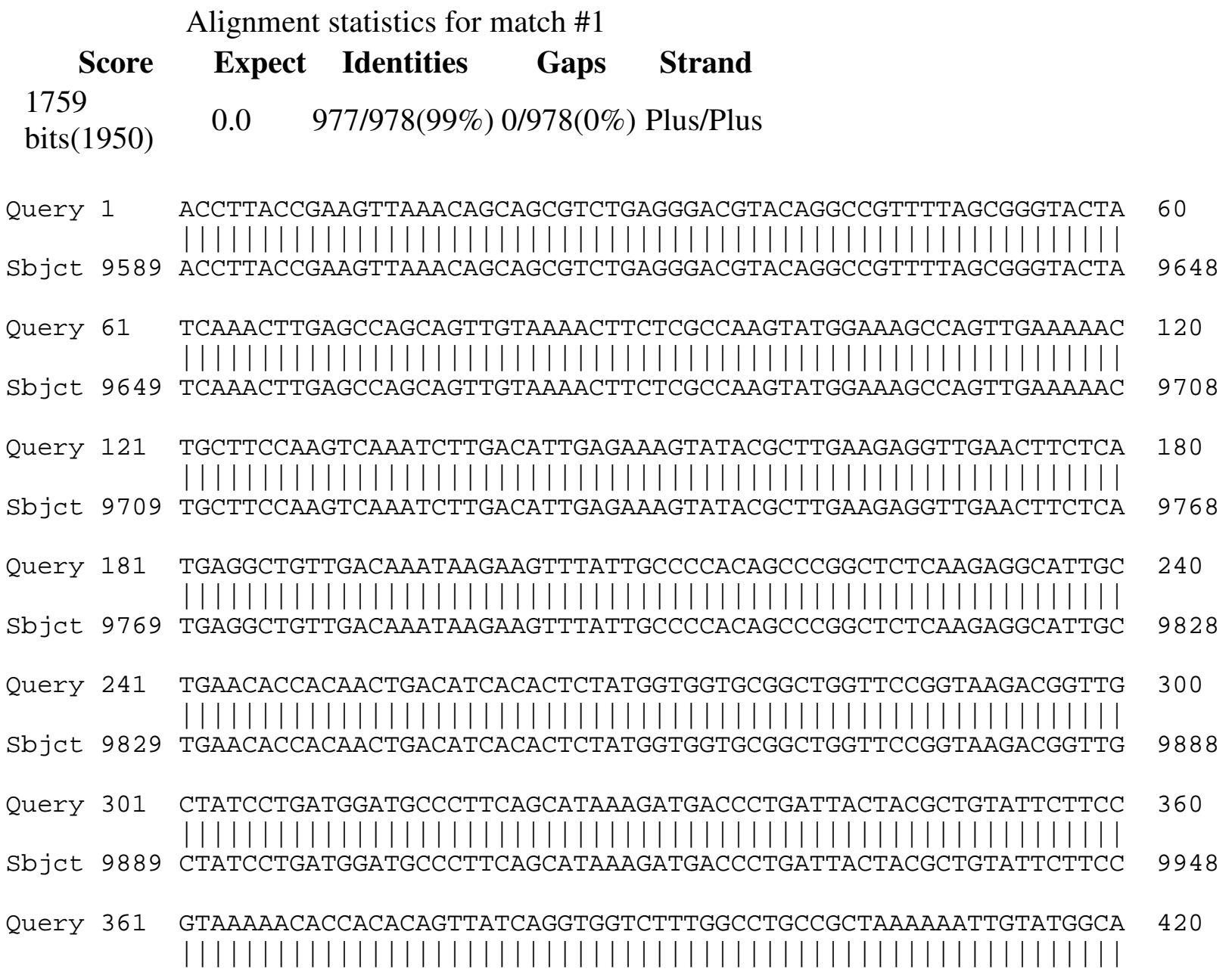




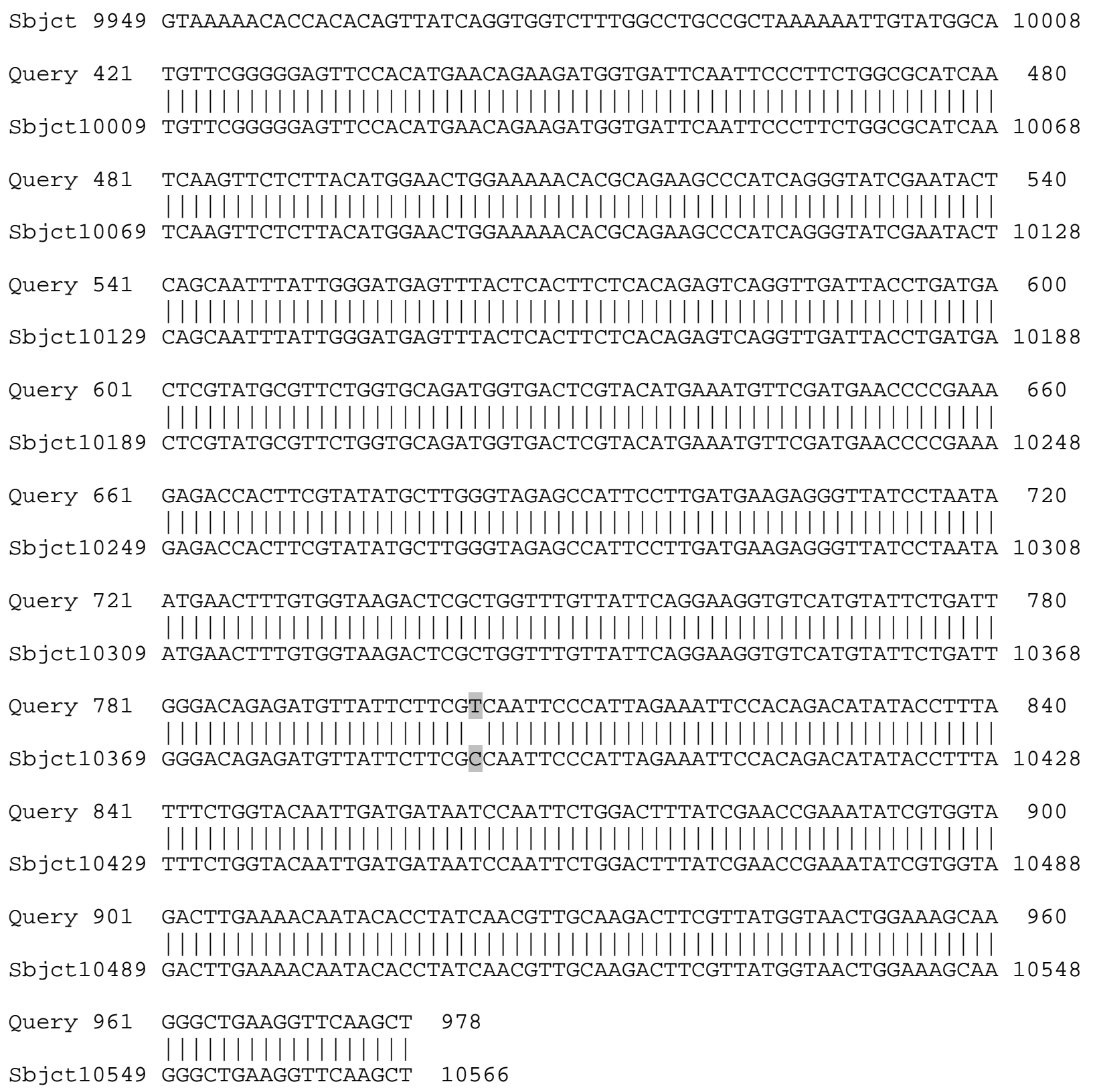

terminase large subunit (9585..11189)

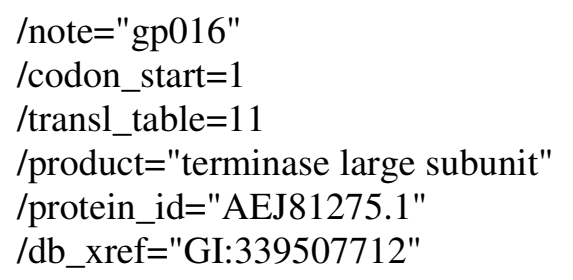

/translation="MNLTEVKQQRLRDVQAVLAGTIKLEPAVVKLLAKYGKPVEKLLPSQILTLRKYTLEEVELL MRLLTNKKFIAPQPGSQEALLNTTTDITLYGGAAGSGKTVAILMDALQHKDDPDYYAVFFRKNTTQLSGG LWPAAKKLYGMFGGVPHEQKMVIQFPSGASIKFSYMELEKHAEAHQGIEYSAIYWDEFTHFSQSQVDYLM TRMRSGADGDSYMKCSMNPERDHFVYAWVEPFLDEEGYPNNELCGKTRWFVIQEGVMYSDWDRDVILR QFPLEIPQTYTFISGTIDDNPILDFIEPKYRGRLENNTPINVARLRYGNWKARAEGSSYFDRRWCQIVDSVDE PASRVRAWDLAATLPSELNPDPDWTAGVKMSKGQKTGTFYIEHVKRFRDRPAGVEEGIQETAKADTSKVE IFIPQDPGAAGKSYASGLIRKLALAGFRARARTTNKDKVTRFAPFSAVAESGHVKVVRGDWNDAYFTELE GFTGDGKRKDDQVDATSDAFQSLNSRGVLKVPSMDNSLDMLRDNPFAGIKTI" 
M16. A H5K fágizolátum Term-F/R primerpárral felszaporított DNS szakaszának szekvenciaanalízise

\section{A H5K terminázt kódoló szakaszának nukleotid sorrendje}

AGCAGCGTCTGAGGGACGTACAGGCCGTTTTAGCGGGTACTATCAAACTTGAGCCAGCAGTTGTAAAA CTTCTCGCCAAGTATGGAAAGCCAGTTGAAAAACTGCTTCCAAGTCAAATCTTGACATTGAGAAAGTA TACGCTTGAAGAGGTTGAACTTCTCATGAGGCTGTTGACAAATAAGAAGTTTATTGCCCCACAGCCCG GCTCTCAAGAGGCATTGCTGAACACCACAACTGACATCACACTCTATGGTGGTGCGGCTGGTTCCGGT AAGACGGTTGCTATCCTGATGGATGCCCTTCAGCATAAAGATGACCCTGATTACTACGCTGTATTCTTC CGTAAAAACACCACACAGTTATCAGGTGGTCTTTGGCCTGCCGCTAAAAAATTGTATGGCATGTTCGG GGGAGTTCCACATGAACAGAAGATGGTGATTCAATTCCCTTCTGGCGCATCAATCAAGTTCTCTTACAT GGAACTGGAAAAACACGCAGAAGCCCATCAGGGTATCGAATACTCAGCAATTTATTGGGATGAGTTT ACTCACTTCTCACAGAGTCAGGTTGATTACCTGATGACTCGTATGCGTTCTGGTGCAGATGGTGACTCG TACATGAAATGTTCGATGAACCCCGAAAGAGACCACTTCGTATATGCTTGGGTAGAGCCATTCCTTGA TGAAGAGGGTTATCCTAATAATGAACTTTGTGGTAAGACTCGCTGGTTTGTTATTCAGGAAGGTGTCAT GTATTCTGATTGGGACAGAGATGTTATTCTTCGTCAATTCCCATTAGAAATTCCACAGACATATACCTT TATTTCTGGTACAATTGATGATAATCCAATTCTGGACTTTATCGAACCGAAATATCGTGGTAGACTTGA AAACAATACACCTATCAACGTTGCAAGACTTCGTTATGGTAACTGGAAAGCAAGGGCTGAAGGTTCAA GCTATTTTGATAGAAGATGGTGATTTCCCA

\section{Szekvencia összehasonlitás}

Erwinia phage vB_EamM-M7, complete genome

Sequence ID: gblHQ728263.1|Length: 84694Number of Matches: 1

Related Information

Range 1: 9607 to 10585GenBankGraphics Next Match Previous Match

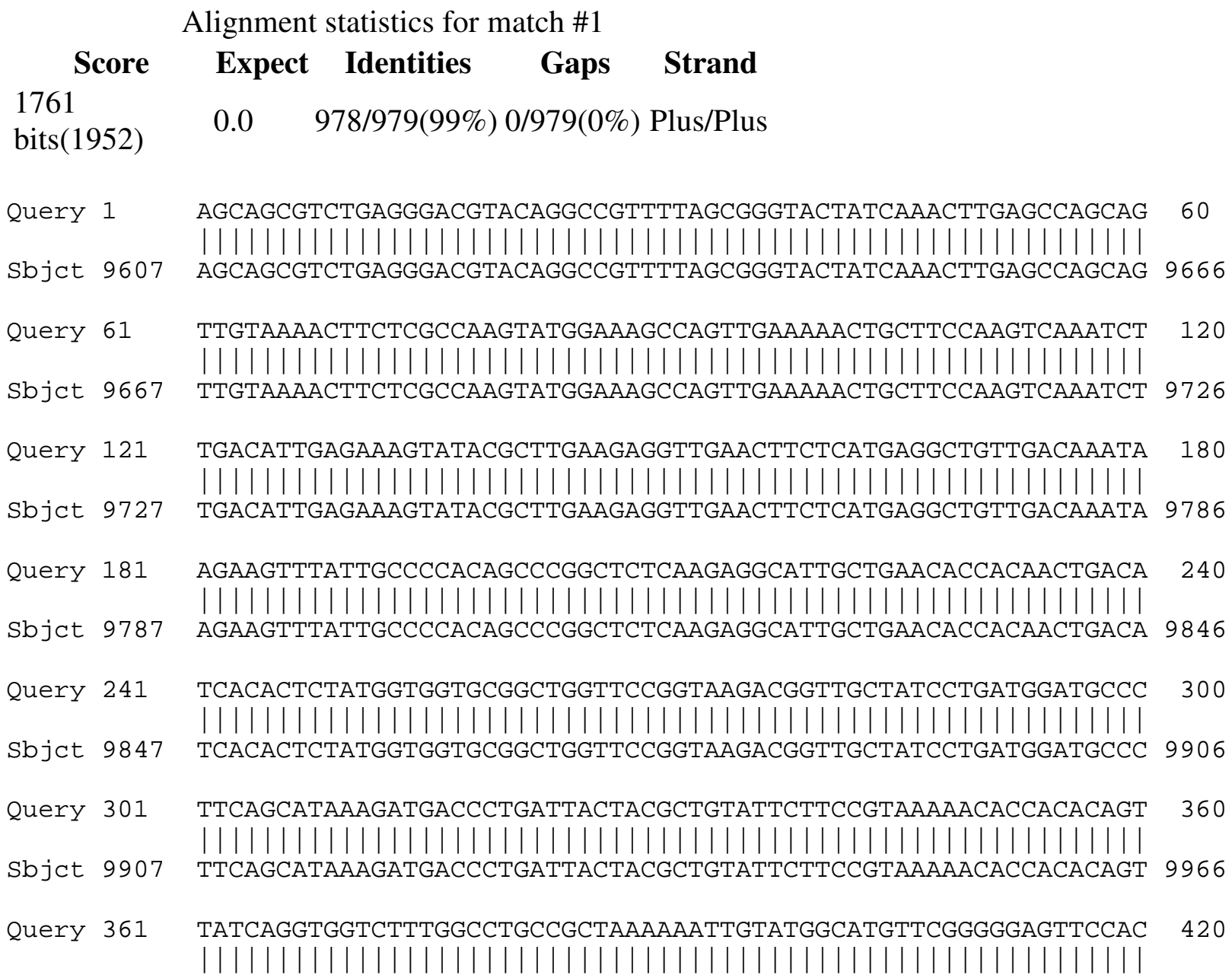




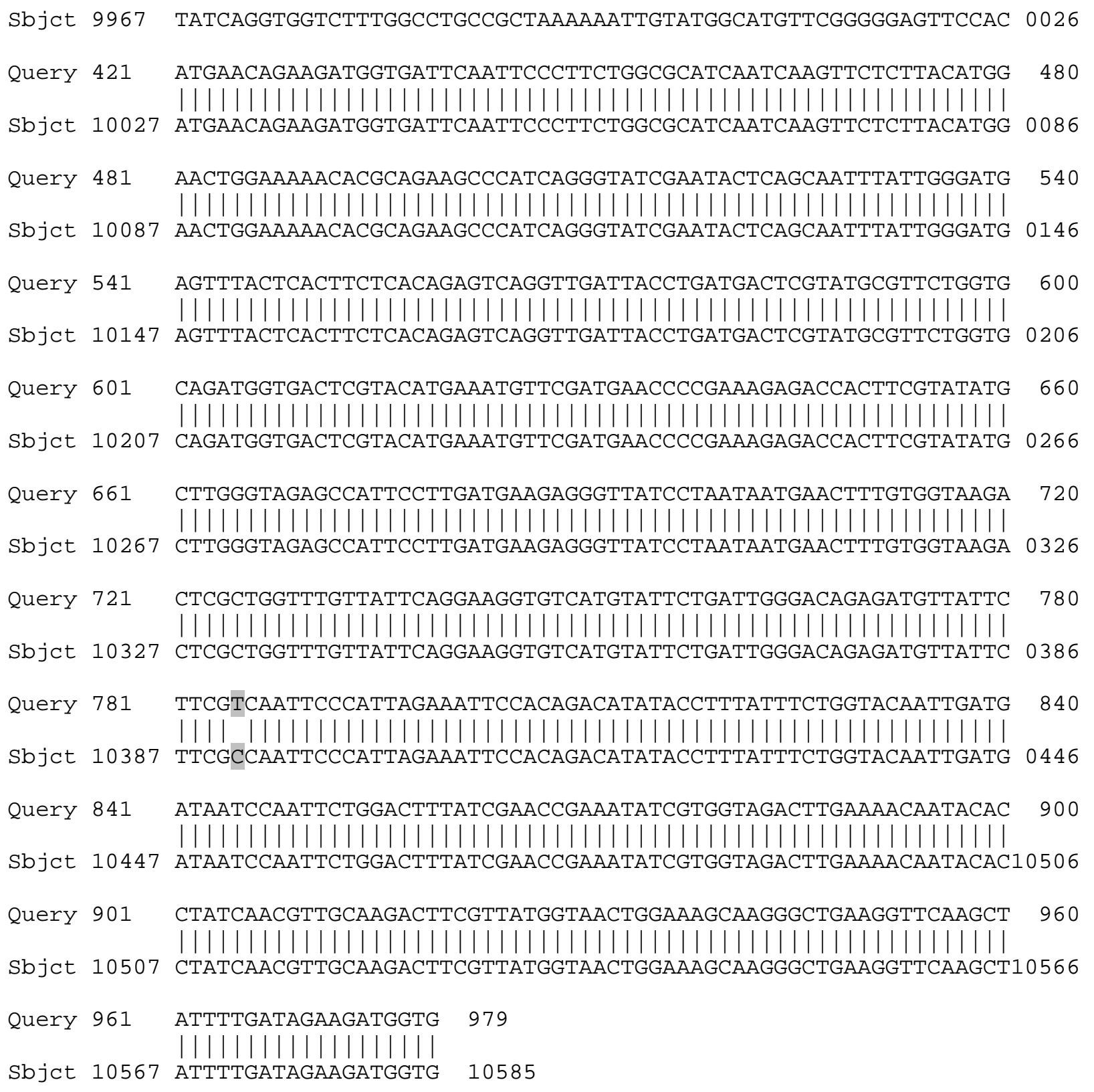

terminase large subunit (9585..11189)

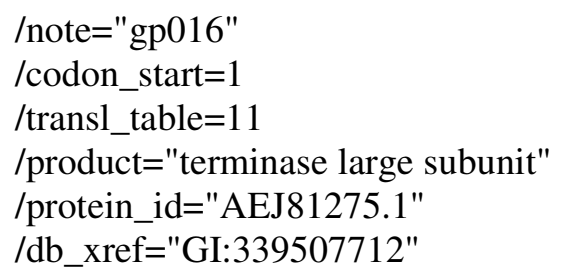

/translation="MNLTEVKQQRLRDVQAVLAGTIKLEPAVVKLLAKYGKPVEKLLPSQILTLRKYTLEEVELL MRLLTNKKFIAPQPGSQEALLNTTTDITLYGGAAGSGKTVAILMDALQHKDDPDYYAVFFRKNTTQLSGG LWPAAKKLYGMFGGVPHEQKMVIQFPSGASIKFSYMELEKHAEAHQGIEYSAIYWDEFTHFSQSQVDYLM TRMRSGADGDSYMKCSMNPERDHFVYAWVEPFLDEEGYPNNELCGKTRWFVIQEGVMYSDWDRDVILR QFPLEIPQTYTFISGTIDDNPILDFIEPKYRGRLENNTPINVARLRYGNWKARAEGSSYFDRRWCQIVDSVDE PASRVRAWDLAATLPSELNPDPDWTAGVKMSKGQKTGTFYIEHVKRFRDRPAGVEEGIQETAKADTSKVE IFIPQDPGAAGKSYASGLIRKLALAGFRARARTTNKDKVTRFAPFSAVAESGHVKVVRGDWNDAYFTELE GFTGDGKRKDDQVDATSDAFQSLNSRGVLKVPSMDNSLDMLRDNPFAGIKTI" 
M17. A H2A fágizolátum Mu-F/R primerpárral felszaporított DNS szakaszának szekvenciaanalízise

\section{A H2A Mu-szerü profág proteint kódoló régiójának nukleotid sorrendje}

TTGAGCTAGGTTTCATGAGAAGGTCATCAAAGGTTTACAAAGGGTTGAAAAGACTGCTATGGCAGCAG CAACCCGAATTGAAAACCGCCTCAACAAAGCCGTATCAATCGACGGGAACAAGTCTAAAGCTGGTTTC GATAAGATTGTACGAAACGCTCAAACCGCTGCTAACAGTGTTAACAGGGCTTTCTCCAAGAGTATGGA TTTTGGGAATGCTGGTAAGGCTTCCGTGAAGGGCGTAGAAACGGCTGCAAGAGCCTCTGCAAAGCGTA TTAAGAAAGAGATGCAGGATGCCTTTAACGTTCGTGGTAATGGGCGTGGAGGCGGTTCTGGAGGCTCT GGAGGGGGTAGACCTCCGAGAGGTGGTAGCGGTAGTGGTGGAGGTTCTTCTAACTCTGCTGCACGTTC AATTGAAAGAACCTACTCAAACAACTACTATTCTGGTCTGACACGTAAACTGGAAAGTATGGGTGTTC GTGGTCAGGGTCTTGCTGGTAAGTTTCGTTCAGACATTACAGGTCTTCGTGATGAAGCACTGAAAAAC CCTGCAACGAACTTAGCAAACTATAACATGCAAGTCAAGGCATCTATCGACGCTATGAAGCGTTGGAT TTCTGCTGAGAATGCTGAGGCTAAGGCTCGTCGTGAACAGACATGGCTTCTGGGACAGAG

\section{Szekvencia összehasonlítás}

Erwinia phage vB_EamM-M7, complete genome $669 / 673(99 \%)$

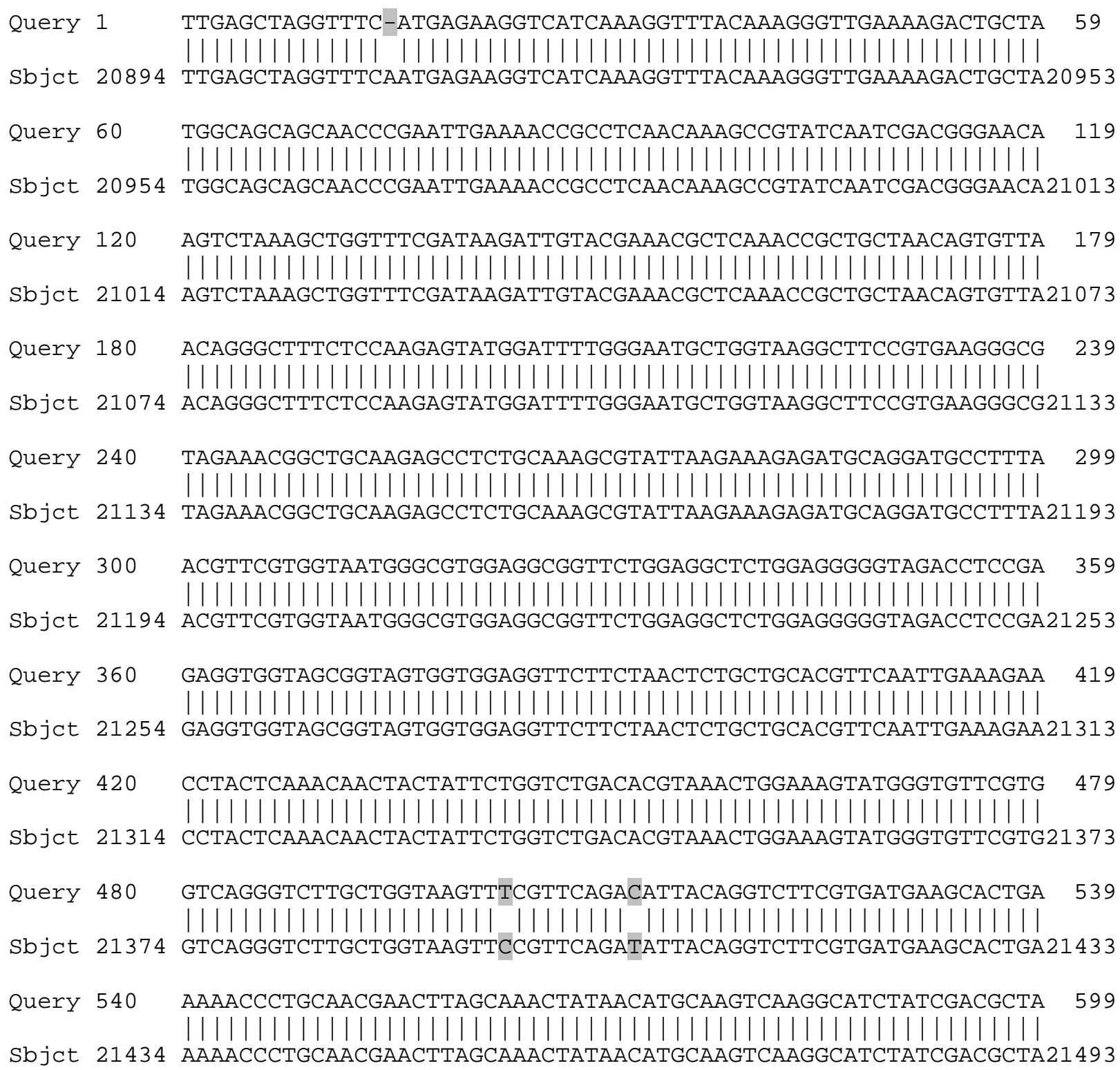




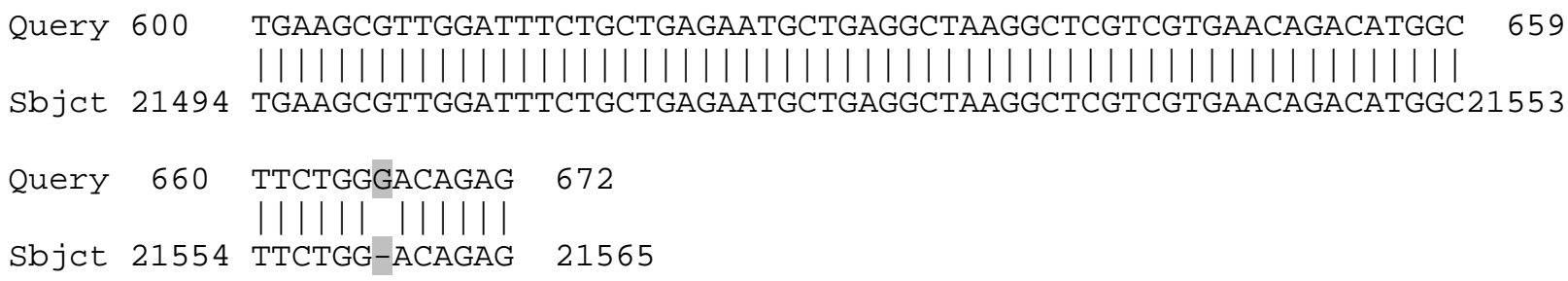

M18. A H5K fágizolátum Mu-F/R primerpárral felszaporított DNS szakaszának szekvenciaanalízise

A H5K Mu-szerü profág proteint kódoló régiójának nukleotid sorrendje

GTTTCATGAGAAGGTCATCAAAGGTTTACAAAGGGTTGAAAAGACTGCTATGGCAGCAGCAACCCGA ATTGAAAACCGCCTCAACAAAGCCGTATCAATCGACGGGAACAAGTCTAAAGCTGGTTTCGATAAGAT TGTACGAAACGCTCAAACCGCTGCTAACAGTGTTAACAGGGCTTTCTCCAAGAGTATGGATTTTGGGA ATGCTGGTAAGGCTTCCGTGAAGGGCGTAGAAACGGCTGCAAGAGCCTCTGCAAAGCGTATTAAGAA AGAGATGCAGGATGCCTTTAACGTTCGTGGTAATGGGCGTGGAGGCGGTTCTGGAGGCTCTGGAGGG GGTAGACCTCCGAGAGGTGGTAGCGGTAGTGGTGGAGGTTCTTCTAACTCTGCTGCACGTTCAATTGA AAGAACCTACTCAAACAACTACTATTCTGGTCTGACACGTAAACTGGAAAGTATGGGTGTTCGTGGTC AGGGTCTTGCTGGTAAGTTTCGTTCAGACATTACAGGTCTTCGTGATGAAGCACTGAAAAACCCTGCA ACGAACTTAGCAAACTATAACATGCAAGTCAAGGCATCTATCGACGCTATGAAGCGTTGGATTTCTGC TGAGAATGCTGAGGCTAAGGCTCGTCGTGAACAGACATGGCTTCTGGGACAGAGA

Szekvencia összehasonlítás

Erwinia phage vB_EamM-M7, complete genome

Sequence ID: gb|HQ728263.1|Length: 84694Number of Matches: 1

Related Information

Range 1: 20853 to 21556GenBankGraphics Next Match Previous Match

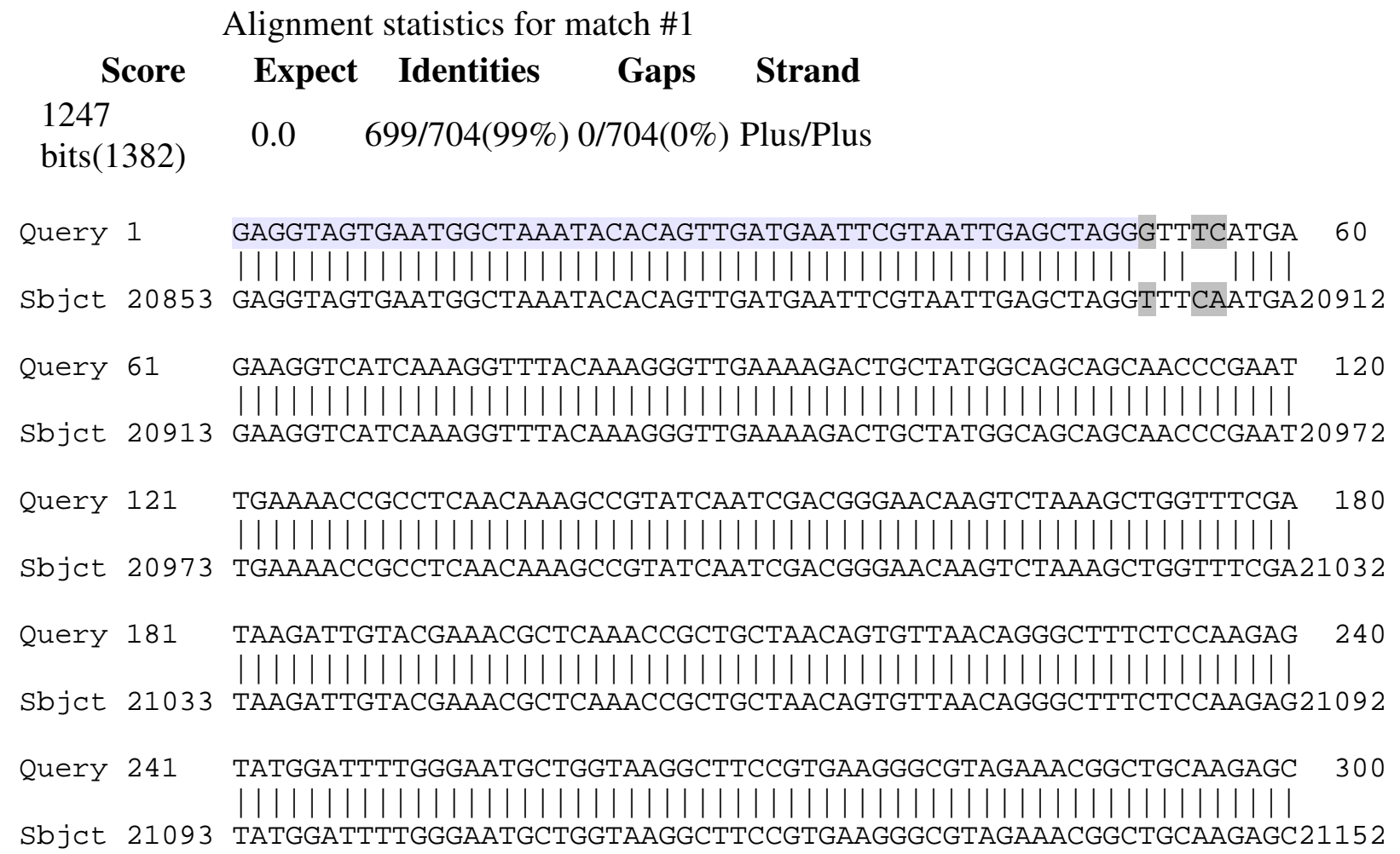


Query 301 CTCTGCAAAGCGTATTAAGAAAGAGATGCAGGATGCCTTTAACGTTCGTGGTAATGGGCG

Sbjet 21153 CTCTGCAAAGCGTATTAAGAAAGAGATGCAGGATGCCTTTAACGTTCGTGGTAATGGGCG21212

Query 361 TGGAGGCGGTTCTGGAGGCTCTGGAGGGGGTAGACCTCCGAGAGGTGGTAGCGGTAGTGG 420

|||||||||||||||||||||||||||||||||||||||||||||||||||||||||

Sbjet 21213 TGGAGGCGGTTCTGGAGGCTCTGGAGGGGGTAGACCTCCGAGAGGTGGTAGCGGTAGTGG21272

Query 421 TGGAGGTTCTTCTAACTCTGCTGCACGTTCAATTGAAAGAACCTACTCAAACAACTACTA 480 ||||||||||||||||||||||||||||||||||||||||||||||||||||||

sbjet 21273 TGGAGGTTCTTCTAACTCTGCTGCACGTTCAATTGAAAGAACCTACTCAAACAACTACTA21332

Query 481 TTCTGGTCTGACACGTAAACTGGAAAGTATGGGTGTTCGTGGTCAGGGTCTTGCTGGTAA 540

||||||||||||||||||||||||||||||||||||||||||||||||||||||||||

Sbjet 21333 TTCTGGTCTGACACGTAAACTGGAAAGTATGGGTGTTCGTGGTCAGGGTCTTGCTGGTAA21392

Query 541 GTTTCGTTCAGACATTACAGGTCTTCGTGATGAAGCACTGAAAAACCCTGCAACGAACTT 600

sbjet 21393 GTTCCGTTCAGATATTACAGGTCTTCGTGATGAAGCACTGAAAAACCCTGCAACGAACTT21452

Query 601 AGCAAACTATAACATGCAAGTCAAGGCATCTATCGACGCTATGAAGCGTTGGATTTCTGC 660

Sbjet 21453 AGCAAACTATAACATGCAAGTCAAGGCATCTATCGACGCTATGAAGCGTTGGATTTCTGC21512

Query 661 TGAGAATGCTGAGGCTAAGGCTCGTCGTGAACAGACATGGCTTC 704

|||||||||||||||||||||||||||||||||||||||

sbjet 21513 TGAGAATGCTGAGGCTAAGGCTCGTCGTGAACAGACATGGCTTC 21556

M19. Az 'Idared' fajtán végzett (2012) virágkísérletek valós idejü („real-time”) PCR vizsgálata során alkalmazott kalibrációs görbe és a hozzátartozó adatok.

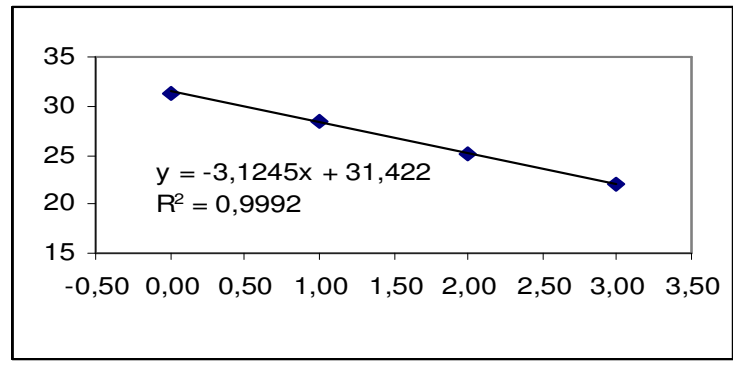

\begin{tabular}{rrrrr} 
& átlag & $\underline{\text { szórás }}$ & átlag & $\underline{\text { szórás }}$ \\
\hline H2A+Ea & 30,09 & 1,16 & 2,67 & 0,10 \\
H5K+Ea & 29,42 & 1,60 & 4,36 & 0,24 \\
H7B+Ea & 30,76 & 1,63 & 1,62 & 0,09 \\
Kombináción & 30,47 & 1,27 & 2,01 & 0,08 \\
Ea & 29,18 & 1,35 & 5,21 & 0,24 \\
H2O & 33,65 & 2,30 & 0,19 & 0,01
\end{tabular}

higítás: $10 x$

\begin{tabular}{|c|c|c|c|}
\hline $\mathbf{0}$ & konc & log(konc) & $\mathbf{c p}$ \\
\hline $\mathbf{1 / 7} \mathbf{- 2}$ & 1000,00 & 3,00 & 22,07 \\
\hline $\mathbf{1 / 7}-\mathbf{3}$ & 100,00 & 2,00 & 25,06 \\
\hline $\mathbf{1 / 7}-\mathbf{4}$ & 10,00 & 1,00 & 28,45 \\
\hline $\mathbf{1 / 7}-\mathbf{5}$ & 1,00 & 0,00 & 31,36 \\
\hline & & & \\
\hline
\end{tabular}

$$
\begin{array}{rr}
\mathbf{y}=\mathbf{a x}+\mathbf{b} & \\
\mathbf{a}: & -3,12 \\
\mathbf{b}: & 31,42
\end{array}
$$




\section{KÖSZÖNETNYILVÁNÍTÁS}

Szeretnék ezúton is köszönetet mondani témavezetőmnek, Dr. Schwarczinger Ildikónak, akinek kutatási témájához csatlakozhattam. Hálásan köszönöm a sok szakmai és baráti segítségét, mely nélkül nem készülhetett volna el ez a munka. Korábbi témavezetőmnek és osztályvezetőnknek, Dr. Süle Sándornak is hálával tartozom azért, mert munkatársnak és egyben PhD hallgatónak fogadott és mindvégig támogatott. Hálás köszönettel tartozom Dr. Hevesi Marikának, korábbi társtémavezetőmnek, akihez bármikor fordulhattam szakmai segítségéért. Köszönet illeti Dr. Tóth Magdolnát, aki a kezdetektől támogatta a kutatómunka és a dolgozat elkészültét. Dolgozatom nem jöhetett volna létre Dr. Király Lóránt szakmai és emberi támogatása nélkül. Köszönöm Pázmándi Ildikónak, Szani Zsoltnak és Novák Edinának a kísérleti anyagok egy-egy részének begyüjtését. Köszönettel tartozom többek között Klaus Geider professzor úrnak és Dr. Bozsó Zoltánnak az egyes baktériumtörzsek biztosításában, Dr. Oros Gyulának és Dr. Pogány Miklósnak az adatok statisztikai értékelésében nyújtott segítségükért. Öszinte hálával tartozom Dr. Fodor Józsefnek és Köblös Gabriellának a molekuláris munkákban nyújtott szíves segítségükért valamint Dr. Mergenthaler Emesének és Rohm Csillának a folyamatos támogatásukért. Végül, de nem utolsó sorban szeretnék köszönetet mondani családomnak, az intézet vezetőségének és minden kedves kollégámnak, akik biztattak és segítségüket nyújtották ahhoz, hogy ez a dolgozat elkészülhessen.

A vizsgálatok a 75280 számú PD OTKA pályázat támogatásával készültek. 